\title{
East German Literature after the Wende. Kerstin Hensel, Angela Krauß, and the Weiterschreiben of GDR-literature
}

\author{
Ulrike Kalt Wilson \\ Hampden-Sydney, VA
}

Erstes Staatsexamen, English and Physical Education, Johannes Gutenberg Universität, Mainz, Germany, 1979

M.A. English and Canadian Literature, York University, Toronto, Canada, 1979

Zweites Staatsexamen, English and Physical Education, Studienseminar Mainz, Mainz, Germany, 1982

Post-Graduate Studies in English Literature, Rhetoric, and Composition, The Ohio State University, Columbus, Ohio (1982-1987)

M.A. German Literature, University of Virginia, Charlottesville, 2004

A Dissertation presented to the Graduate Faculty of the University of Virginia in Candidacy for the Degree of

Doctor of Philosophy

Department of Germanic Languages and Literatures

University of Virginia

December 2011

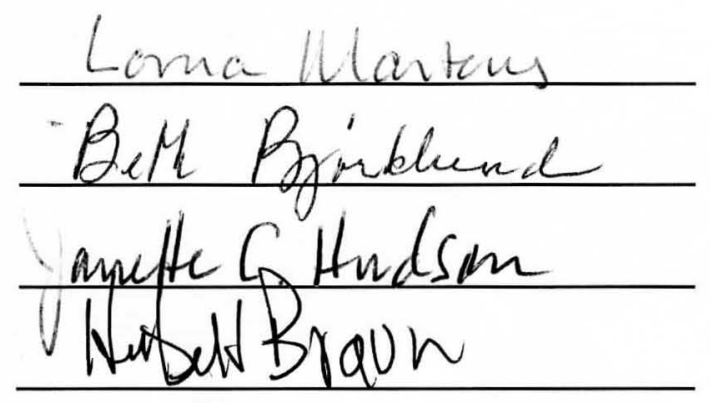




\begin{abstract}
This project contributes to the current debate about the future role of GDRliterature in Germany's post-WWII literary history. Among three distinct groups of literary critics and historians, the first focuses on the formal and aesthetic similarities between East and West German literatures and argues for a merging of the two. The second maintains that literature from the former GDR should be considered a regional variant of post-WWII German literature, thus emphasizing and preserving the political, historical, and cultural differences between the two countries and their literatures. Within this second group, some even claim that though the state GDR no longer exists, GDRliterature is still being written.
\end{abstract}

Siding with this third group, I argue that the GDR's unique history - its socialist past and the dramatic effects of the Wende-gave, and still gives, rise to a literature with a distinctly regional character both in form and content. In support of my argument, I first address the question of what we mean by GDR-literature and identify certain characteristic features of this literature. I then show that there is indeed such a phenomenon as a Weiterschreiben of GDR-literature. To demonstrate that there is indeed a post-GDR-literature in the tradition of GDR-literature, I examine three fictional texts by East German writers Kerstin Hensel and Angela Krauß. I discuss how both writers’ choices of subject matter are directly related to the GDR's unique past and present situation and how their narrative methods can be traced back to the kinds of writing styles previously identified as particular to the GDR's literary scene. Maintaining the idea of two German literatures preserves the memory of a unique and important phase in post- 
WWII German literary history and accords with the emerging pluralism and multiculturalism in Germany's literary scene. 


\section{Contents}

Introduction

Chapter One. The Case of GDR-Literature 12

I. Introduction

II. Germany’s Literary Battle of the Early 1990s 15

III. Nationhood, Politics, and Aesthetics 26

IV. Characteristic Themes and Writing Styles of GDR-Literature 38

$\begin{array}{ll}\text { V. Conclusion } & 71\end{array}$

Chapter Two. Kerstin Hensel's Gipshut: Weiterschreiben and the Aesthetics of Disorder $\quad 73$

I. Introduction

II. Kerstin Hensel on Writing and Being an East German

Writer

III. The Disorderly World of Gipshut and Hensel's $\begin{array}{ll}\text { Disorderly Narrating } & 88\end{array}$

$\begin{array}{ll}\text { IV. Conclusion } & 149\end{array}$

Chapter Three. "Wann, wenn nicht jetzt." Angela Krauß and the

Writing of Life

I. Introduction

II. Angela Krauß, the Writer

III. Die Überfliegerin. Caught between the 'No Longer' and the 'Not Yet' 
IV. Weggeküsst. “. . . um uns unseres eigenen Rätsels zu versichern” 200

$\begin{array}{ll}\text { V. Conclusion } & 238\end{array}$

$\begin{array}{ll}\text { Conclusion } & 243\end{array}$

I. Hensel, Krauß and Weiterschreiben. A Summary 243

II. Weiterschreiben and Wendeliteratur 251

Works Consulted 255 
Für meine Eltern Marianne und Fritz Kalt;

für meine Töchter Monika Leah und Shannon Alexandra;

für meinen Mann Patrick. 


\section{Introduction}

Zeit fiel aus Zeit und alterte. Zeit blieb Zeit auf einer Uhr ohne Zeiger. . . Sie sprang, sie kreiste, sie eilte dahin: eine Kugel, die eine engläufige Schneckenbahn hinabrollte. (Uwe Tellkamp, Der Turm, 890)

\section{The Argument}

Literature in the reunited Germany is in a state of transition with no clearly identifiable direction. The heated and often highly emotional debates of the literary battle in the early nineties have quieted down (and not much ever came of them); readers and critics have long given up waiting for the Wenderoman; and most of all, just as economically and socially the Germany of the new millennium is still very much a divided country, so is its literature.

In the introduction to his and Gerhard Fischer's collection of essays about the development of German literature during the first ten years after reunification, David Roberts remarks that German literature at the end of the twentieth century is characterized by plurality rather than unity (Schreiben nach der Wende, xi). On the topic of Germany's post-Wende literature, he notes that it is still too early to give a structured survey or identify any major emerging patterns of thoughts. Indeed, he wonders whether in the age of globalization and multiculturalism, the concept of "Epochendiskursen"i.e., the idea of there being a unified discourse during a particular historical period-is not perhaps outdated or even impossible (xiii). And as to the merging of the two post-war German literatures into a new Nationalliteratur, Roberts argues that in the context of the recent changes within Europe, such an undertaking would be anachronistic and should 
altogether be abandoned (xv). Also, Germany's literary market at the beginning of the twenty-first century clearly reflects the country's change towards becoming a multicultural society, a fact that directly undermines the idea of a Nationalliteratur.

One of the issues yet to be resolved is how to deal with the two German literatures that emerged during the fifty years of the country's division. More specifically, what should the role of literature from the former GDR be in Germany's future literary history. One option would be considering it a regional variant of German speaking literatures in general, much like Austrian or Swiss-German literature. This would be a way of emphasizing and preserving the differences between the two literatures. Another option would be to leave aside all regional, national, and cultural differences, as was done by Ralf Schnell in the second, revised and expanded edition of his Geschichte der deutschsprachigen Literatur seit 1945, published in 2003. Schnell discusses the works of writers from the former GDR side by side with those from the other German speaking countries. His history is organized according to overarching themes, such as "Literatur versus Politik - Konstellationen der fünfziger Jahre" or "Im Zeichen der Postmorderne (1978-1989)." In his history, literature from the neue Bundesländer (he labels it "WendeLiteratur") is just one of the many sections of his final chapter "1989 und die Folgen." Located at the other end of the spectrum is the expanded, new edition of Wolfgang Emmerich's Kleine Literaturgeschichte der DDR, published in 2000. As the title suggests, Emmerich's is a literary history of works by writers from the pre- and postWende East. By maintaining the idea of a separate post-WWII East and West German literary tradition, Emmerich wants to emphasize and preserve the differences between the two kinds of German literature. The difference in Schell's and Emmerich's approach to 
literary history is one of perspective and depends on how much emphasis each historian puts on the cultural, social, and historical context within which a literature is produced.

Another question to be dealt with is that of historiography. Writing a literary history of the united Germany depends not just on the historian's perspective as a number of other, interrelated issues are complicating the process. There is first of all the question of what exactly is to be understood by GDR-literature, a phenomenon whose defining characteristic is its chameleon-like quality: depending on who is using the term and when and where, its meaning changes dramatically. This problem is further aggravated by the question whether the end of the state GDR also signifies the end of GDR-literature. Is it perhaps possible to apply the label GDR-literature to works written in the neue Bundesländer after 1989? If so, under what circumstances could this happen, and how would this affect and change the meaning of the term GDR-literature?

Immediately after the Fall of the Wall, critics and historians were mostly concerned with a re-reading and re-evaluating of literature from the former GDR. The many heated debates about the literary value of works by GDR writers and about the relationship between ideology, cultural politics, and aesthetics in general are now known as the deutsch-deutsche Literaturstreit. Also, while for some the end of the GDR also meant the end of GDR literature, others saw (and still see) in the literature emerging in the new East signs of its continuation. Clearly, at some point, a decision needed to be made about what exactly were the essential characteristics of this literary phenomenon GDR-literature. (The one point everyone agrees upon, however, is that there is more to GDR-literature than just the state-sanctioned, system affirmating literature, since works belonging to this category never played an important role in the country's literary scene.) 
When, starting in the mid-nineties, a great variety of fictional texts by writers from the former GDR began flooding Germany's literary market, this question of definition took on new importance. Some of these texts were unconventional and sophisticated postmodern texts such as the fictions of Reinhard Jirgl or Wolfgang Hilbig; others were light und humorous, and more accessible to a general audience. These include works by Ingo Schulze, Jana Hensel, and Thomas Brussig. Also, while some writers wrote fictions that recaptured the past, other focused on issues related to the immediate present. The term Wendeliteratur was coined, but since the term was never clearly defined, it soon outlived its usefulness. This sudden prolificacy of East German writers led Iris Radisch to speak of a "zweiten Leben der DDR nach ihrem Untergang” (quoted in Roberts, xv). The themes, the perspectives, and often also the writing styles of these works were distinctly different from what was being written in the West at that time. Clearly, the GDR had not yet died but kept living on in the imagination of the region's writers. Thus the idea of a Weiterschreiben of GDR-literature was born. Publications with such titles as, Literatur und Wende: Ostdeutsche Autorinnen und Autoren nach 1989 (Kormann, 1999); Weiter schreiben: Zur DDR-Literatur nach dem Ende der DDR (Helbig, 2007); ${ }^{1}$

${ }^{1}$ Though Helbig uses idea of Weiterschreiben in the title of his book, his understanding of the term is different from mine. First of all, Helbig's book is a collection of conference papers about the status of GDR-literature after the end of the GDR, and the notion of Weiterschreiben is really only discussed in his contribution to the collection. Second, he uses the term in the larger context of identifying different ways of dealing with the literary heritage of the GDR and its afterlife. Accordingly, he distinguishes between four categories: Umschreiben, Weiterschreiben, Nachschreiben, and Neuschreiben. His understanding of Weiterschreiben is twofold. Concerning those writers who published during the years of the GDR's existence, he is interested in how their texts written before 1989 are being read now, in the new historical and political context, and how form and content of their writing have changed since 1989-this is also where his interpretation of the term overlaps with Köhler's approach. And when he talks about Neuschreiben, he focuses on the new voices to be heard in the post-1989 East. Now 
Brückenschläge: DDR Autoren vor und nach der Wiedervereinigung (Köhler, 2007); and Schreiben nach der Wende - Wende im Schreiben? Literarische Reflexionen nach 1989/90 (Reimann, 2008) all attest to the growing interest in the contemporary literary scene of the region formerly known as the GDR. ${ }^{2}$

But what exactly do these critics mean, when they speak of a Weiterschreiben? There is first of all the most obvious meaning of the word-that writers from the former GDR not only continued to write but, and this is Julia Kormann's and Astrid Köhler's point, that there is also a certain continuity in their writing styles. Köhler's book deserves special mention here because it includes a discussion of both Kerstin Hensel and Angela Krauß. But Köhler is interested solely in the question of a literary continuity (literarische Kontinuität) within these writers' oeuvre, and she compares their pre- and post-Wende fictions, while I am taking a more general approach as I am looking for continuations that relate to the field GDR-literature, for ways in which both writers' post-Wende works represent a continuation of the GDR's literary traditions. Köhler gives a very detailed description of how in Hensel's and Krauß's texts written after 1989 not only show a continuation of their particular aesthetics but how in these texts one can also find numerous other connections (some hidden, some obvious) to their pre-Wende fictions. Aside from certain aesthetic characteristics, these connections may be direct references to

he is concerned with the question to what extent their works deal with GDR themes and topoi and whether in these texts one can also see a continuation of literary strategies. As will be explained later, my understanding of Weiterschreiben is closer to Helbig's notion of a Neuschreiben, but it is more inclusive.

${ }^{2}$ Most of the secondary texts mentioned in this project have not been translated into English; the translations offered are therefore my own. Similarly, most of the primary texts mentioned in the chapter on GDR-literature including the texts by Angela Krauß and Kerstin Hensel have not been translated into English. For the sake of being consistent, quotations from these texts will be given in German only. 
the previous texts, direct quotations, a repetition of thought patterns and opinions, or even the continuation of certain topics. ${ }^{3}$ Next, there is a Weiterschreiben in the sense that the GDR-past (including present issues that directly relate to the country's past history) keeps being written about. Memories of how it once was live on in the form of themes and certain literary topoi, and the dramatic changes of the present virtually beg to be transformed into literature. Finally, Weiterschreiben, the way I am using it, also refers to the continuation of certain formal and narrative methods typical of literary texts from the former GDR.

It is primarily these last two notions of Weiterschreiben-the GDR/new East as subject matter (what Heiner Müller calls Material) and the continuation of a particular/GDR way of writing - that I am interested in when discussing the three texts by Hensel and Krauß. I will use their narratives as paradigmatic cases to show that GDRliterature is not yet a thing of the past. Finally, I will use this idea of a Weiterschreiben to support my opinion that there are two post-war German literatures and that GDRliterature should be given its own place - be considered a separate literary phenomenonwithin contemporary German literary history. The one remaining uncertainty is, however, for how long there will still be this Weiterschreiben of GDR-literature and this notion of a separate East German tradition of writing. The answer to this question depends on the individual writer as well as on the growing together of the formerly divided countries.

Some may find the dividing of post-war German literature artificial or unnecessary especially since during the last decade of the GDR's existence certain

\footnotetext{
${ }^{3}$ Since Köhler provides a very comprehensive discussion of this aspect of Weiterschreiben in Hensel and Krauß, I shall give only a few general comments regarding this particular notion of Weiterschreiben and refer the interested reader to Köhler's Schreibprofile of these two writers.
} 
commonalities between the two German literatures developed. For example, in both countries writers showed an increasing concern with gender and environmental issues. On both sides of the wall there was a noticeable turn towards a more subjective and selfexploratory kind of literature and writers in both countries experimented with postmodern narrative techniques. At the same time, however, there is a noticeable difference between these two literatures, even in the works of writers who were no longer living in the East. This difference is the result of a variety of factors - of the work's geographical and/or social setting, of references to issues specific to life in the former GDR, or of certain preferred ways of narrating and language play - and in many cases, these phenomena prevailed even after the country's demise. ${ }^{4}$

\section{Procedure}

I will back up my argument about the Weiterschreiben of GDR-literature with three fictional narratives by the two East German writers Angela Krauß and Kerstin Hensel. From Krauß's works, I selected her first post-Wende text, Die Überfliegerin (1995) and one of her later works, Weggeküsst, which was published in 2002; from Hensel I chose the novel Gipshut, which was published in 1999.

Studying these two writers in the context of a Weiterschreiben of GDR-literature is interesting primarily because of the difference in their approach to the subject matter of the GDR and the new East. Hensel is the storyteller of the two; her fictional worlds are characterized by being bizarrely off-kilter and chaotic. Similarly, her protagonists are

\footnotetext{
${ }^{4}$ For example, in her book Literatur und Wende, Julia Kormann mentions that there is a division, a diverging of themes and topics, in the literature written after the historical turn by authors with a GDR background. She writes, "Die Literatur nach 1989 markiert . . . ein Interimsstadium zwischen den geteilten Literaturen in BRD und DDR und einer vereinigten, aber in unterschiedlichen Strömungen ausdifferenzierten Literatur" (134).
} 
psychologically misshapen and social outcasts — victims of some delusion or earlier trauma. With her sensitivity for language, her dry sense of humor, and the well-placed irony in her narrating, Hensel evokes in her reader feelings of resentment and disgust but also compassion and sympathy for her characters. Among all of her fictional texts, her novel Gipshut is arguably the most interesting example of the Weiterschreiben of GDRliterature as it is much like a post-modern Heimatchronik. The realistic descriptions and everyday detail are reminiscent of the local color narratives of a Johannes Bobrowski, an Erwin Strittmatter, or a Günter de Bryn. Her narrative method-the inclusion of the surreal and the fantastic, the extensive use of montage, and the narrating voice's absolute detachment - show the influence of Irmtraud Morgner's writing style. It is a unique kind of Weiterschreiben that largely consists of a mocking, a subtle undermining, an ironic play with GDR literary traditions and life in the old and new East. Hensel's main theme in Gipshut as well as in her other post-Wende fictions is the frailty of human nature and the effects of historical processes on people's lives. She wants to keep alive the memory of past mistakes so that they may not be repeated in the future.

Angela Krauß's Weiterschreiben is of a different kind, however. Aside from the fact that her topic is primarily East Germany's post-unification present and specifically the sense of rupture and fragmentation caused by the historical change, her narratives connect with the kind of a reflective, self-exploratory writing to be found in the fictional works by Christa Wolf. Like all of her fictional texts, the two narratives I have selected, are short, intensely poetic, and complex pieces written in a language full of powerful imagery and concise to the point of being enigmatic. Her narratives are best described as loosely connected flashes of thought and epiphanic moments. Also, her sense of humor is 
different from Hensel's, more subtle and with just a touch of irony-gentle and not at all mocking or critical.

Lastly, comparing these writers' literary production since the Fall of the Wall reveals an interesting development in contemporary East German literature. All of Hensel's post-Wende fictions including her latest novel, Lärchenau (2008), have a distinctly regional quality and her preoccupation with with the country's past and present history is as dominant in her latest novel as it is in her very first fictional narrative. By contrast, in Krauß's most recent work, Im schönsten Fall, the GDR-ness has disappeared. It is a collection of contemplations and philosophical ponderings about the human condition in general — about love and friendship, about the search for happiness, and the future of the world.

\section{Structure}

Any project on the topic GDR-literature must of necessity address the question of definition. As René Granzow in his recent study of literature from the GDR and its writers has pointed out, the various attempts so far at defining the term GDR-literature as well as the discussion about one or two German literatures have been and still are rather vague and contradictory (Gehen oder Bleiben? Literatur und Schriftsteller der DDR zwischen Ost und West, 9). Thus, before even thinking of the idea of a Weiterschreiben of GDR-literature, one first has to determine what exactly the characteristic qualities of this literature would be and identify its distinctive themes and writing styles. Such a characterization of GDR-literature combined with a brief description of it will be the main topic of chapter one. I will begin with a short historical survey of GDR-literature, which will help explain the term's chameleon-like quality and provide important insight 
into the complexity of this literary phenomenon. Next, I will summarize the main issues debated in the deutsch-deutsche Literaturstreit, an emotionally charged event, which revealed how difficult it would be to bring together the two German literatures, East and West. After briefly talking about the phenomenon Wendeliteratur, I will then conclude the chapter with a description of what I consider the most defining characteristics formal as well as thematic-of literature written in the GDR.

Chapters two and three, the central parts of this project, are dedicated to the idea of a Weiterschreiben of GDR-literature, and I will use the aforementioned fictional texts by East German writers Kerstin Hensel (chapter two) and Angela Krauß (chapter three) as paradigms of this phenomenon in contemporary German literary history. At the beginning of each chapter, I will briefly talk about the author's development as writer, about her poetics, and about some of the distinctive features of her writing style. The point here is to show how both writers are a product of the time and the place where they grew up and how their writing is inspired by and is a response to the place GDR. In my analysis of the three literary works, I intend to show the distinctive regional character of these works - their GDR-ness - both in form (narrative techniques) and content. Specifically, I will discuss how each writer's choice of subject matter is directly related to the country's unique past and present history and how their narrative methods can be traced back to the kinds of writing styles previously identified as particular to the GDR's literary scene.

In the concluding chapter of my project, I will first summarize the results of the two chapters on Hensel and Krauß by describing the differences and similarities between their ways of Weiterschreiben. Then I will return to the topic of a post-GDR GDR- 
literature and use it to further strengthen my argument against the absorption of GDRliterature into the literary canon of the West. Maintaining the idea of two German literatures and considering GDR-literature as a separate literary phenomenon will help preserve the memory of a unique and important phase in post-WWII German history. Such an approach is in keeping with the emerging pluralism and multiculturalism in German literature. As Germany is turning into a multicultural country, the role of its literature is changing, and the old notion of a German Nationalliteratur has lost its meaning. Regarding GDR-literature as an autonomous literary phenomenon will help promote the idea that German literature today needs to be understood as a reflection of the country's cultural pluralism and not as the foundation of national spirit. ${ }^{5}$

${ }^{5}$ The winner of the 2010 Deutsche Buchpreis, Melinda Nadj Abonij, is one of the many examples of the cultural pluralism in contemporary Germany's literary scene. Nadj Abonij is a Swiss writer and musician of Yugoslav descent, for whom German is a second language. 


\section{Chapter One. The Case of GDR-literature}

Niemand, am wenigsten der

Schriftsteller, kann Freiheit suchen

jenseits der Koordinaten von Raum und Zeit, jenseits der Geschichte und ohne sie. Der geographische Ort, an dem ein Autor lebt und der zugleich ein geschichtlicher Ort ist, bindet ihn. (Christa Wolf, "Lesen und Schreiben," in Dimensionen des Autors, 498)

\section{Introduction}

The Fall of the Wall and German reunification on November 11, 1990, are events that forever changed the social, political, and economic relationships between the two parts of Germany and totally transformed life in the East. Marking not just a historical but also a cultural turning point, reunification also required a revising and rewriting of Germany's post-WWII literary history. Virtually days after the borders were opened, literary historians and critics started debating about ways of incorporating post-war East German literature into a new, common literary history. Should, as a way of emphasizing the differences between the two literatures, literature from the former GDR be considered a separate literary phenomenon among German speaking literatures? Or should there be a merging of the two German literary histories, which would mean prioritizing the commonalities between them? That this was not just a literary but also a political question was soon proven by the heated debates of the deutsch-deutsche Literaturstreit in the early nineties. Writing this new Germany literary history would not only require rereading and re-evaluating the canonical works of both German literatures, but more 
importantly, it would require a clearer understanding of so-called GDR-literature. Before the Wende, works by East German writers that reached the Western market were usually received with favorable reviews and were given special preference, for which the expression DDR-Ursprung Bonus (bonus of GDR-origin) was coined. Almost immediately after the Fall of the Wall, however, such welcoming of literature written in and about the other Germany changed into an attitude of hostility and rejection. More and more, critics focused on political and ethical issues pertaining to the personal life of East German writers rather than on questions of literary merit or values represented in the text itself. Not really leading to any decisive new insights, the emotional nature of these debates as reflected in personal attacks against writers from the former GDR showed the uncertainty and confusion among members of Germany's literary community when faced with the new historical situation.

At the very root of these discussions was the yet-to-be-answered question of how one is to understand the phenomenon GDR-literature, a question that opens a Pandora's box of problems. First of all, even during the time of the GDR's existence, there never was a clear understanding of the specific attributes that characterized its literature. Secondly, soon after reunification, the problem of the term's vagueneness was further aggravated by the question of how tightly the phenomenon GDR-literature was to be linked to the existence of the state GDR. Judged by the literature that emerged in the post-1989 East, there was no sudden break or drastic change in the way writers from the former GDR were writing. On the contrary, the state GDR may have died a sudden death, but it almost immediately came to life again in the literary works of many an East German writer. This fact poses the question whether one can speak of a Weiterleben (a 
continuation) of GDR-literature after the Wende, and this is the question I will address in this project. Before making any kind of statement about a possible Weiterschreiben of GDR-literature, however, I will attempt to clarify what exactly constitutes GDRliterature.

I will begin my investigation into the phenomenon of GDR-literature with an event that immediately followed German reunification, the deutsch-deutsche Literaturstreit of the early 1990s. Though the literary battle did not leave a lasting impact on Germany's literary scene, it was a reflection of the political and cultural tensions within the reunited Germany and brought to the surface some of the long-held prejudices against literature from the former GDR. After summarizing the different phases of the literary battle, I will describe some of the difficulties one encounters when trying to characterize the phenomenon GDR-literature. Perhaps its most characteristic aspect is the fact that there had always been a decisive clash between what GDR-literature was supposed to be and what it really was. This fact led to numerous ambiguities and contradictions in the understanding of the term in both parts of Germany. One of the important insights to be gained here is how deeply entrenched the notion of GDRliterature as political literature really was. Though readers in both Germanys knew of the exceptional literary quality of works by writers such as Christa Wolf, Heiner Müller, Ulrich Plenzdorf or Irmtraud Morgner, there still was the general tendency to focus on the political message relayed in these writers' texts rather than give credit to their play with literary form and language. I will conclude the chapter with a description of what in the course of the GDR's existence became some of the distinctive characteristics of GDR-literature. Aside from giving their works a distinctly regional quality reflected in 
their choice of locale, subject matter, and theme, writers in the former GDR also developed certain formal and stylistic preferences. Though these may not be singular to writing in the former GDR, the frequency in which they occur emphasizes their importance.

\section{Germany's Literary Battle of the Early 1990s}

During the forty years of its existence, literature written in and about the former GDR was received by West German readers and critics as an almost exotic "other" literature about a society and a life that was simultaneously known and unknown. ${ }^{6}$ Though the works of Christa Wolf, Heiner Müller, or Irmtraud Morgner, for example, always received praise for their exceptional literary quality, West German critics tended to focus primarily on the political message of works by writers from the other Germany. Such one-sided reading of GDR-literature was a direct result of the political and ideological tensions between the two Germanys. Any reference to the failure and corruption of GDR socialism reaffirmed Western readers and critics in their belief that theirs was undoubtedly the superior political system. As critic Friedrich Dieckmann put it, the ideological otherness of East German literature was essential to how post-1945 literature in the Federal Republic defined itself (146). With Germany's reunification, this other was suddenly to become part again of its estranged western sibling's literary history. Needless to say, such a reunion would have its challenges.

\footnotetext{
${ }^{6}$ To describe the dramatic differences between the two Germanies Stephen Brockmann, in his book Literature and German Reunification, compares the different realities with Freud's concept of the uncanny. He remarks that to people in the Federal Republic, East Germany is "at once alien and familiar, at once dead and undead, at once hidden and obvious" (172).
} 
Already in 1987, West Germany's literary feuilleton star Marcel Reich-Ranicki had repeatedly criticized the GDR's intellectuals for never openly speaking out against their country's repressive and authoritarian government. Starting in late 1989, with the prospect of unification and a gesamtdeutsche cultural renewal, Reich-Ranicki's earlier remarks suddenly became topical again. They set in motion a series of heated discussions (taking place primarily in the feuilletons of West Germany's major newspapers) between literary critics, historians, and writers from both parts of Germany. These debates have come to be known as the deutsch-deutsche Literaturstreit. Most noteworthy about them is that instead of focusing on questions of literary performance, the discussions almost instantly deteriorated into a back and forth of accusations and polemics about the selfunderstanding and public role of East German and later also West German intellectuals. Critical reflection and reasoned argumentation were replaced by personal attacks and public inquiries into the moral integrity of some of East Germany's most celebrated writers.

Phase One

The event that started this far-reaching crisis within Germany's literary community was the publication of Christa Wolf's short novel Was bleibt, in June $1990 .^{7}$ Even before the novel hit the market, critics Ulrich Greiner (Die Zeit) and Frank Schirrmacher (Frankfurter Allgemeine Zeitung) each published a review that, instead of offering a reasoned discussion of the work's literary aspects, was filled with personal

${ }^{7}$ The content of Was bleibt is obviously autobiographical and refers to a period in Wolf's life (in 1979) when she had indeed been under constant Stasi surveillance. 
attacks against Wolf and her role as a GDR writer. ${ }^{8}$ The problem was that certain facts concerning the novel's publication seemed suspicious, which in the minds of some West German critics raised questions about Wolf's honesty. ${ }^{9}$ For example, though the novel had been written ten years earlier, why had its publication been delayed until exactly that moment when the Stasi, Wolf's “enemy," no longer existed? Secondly, though Wolf claimed to have made major revisions in the fall of 1989 , why had she never provided specific details about the nature and the extent of these revisions? Wolf's silence when confronted with the different accusations did not help her case. Were these incongruities and her refusal to explain herself not signs of her bad conscience about her ambiguous relationship with the State? Ulrich Greiner considered the late publication of Was bleibt dishonest and also insensitive towards those whose lives had been ruined by the Socialist Unity Party's machinations. Similarly, Wolf's most vocal and aggressive opponent, Frank Schirrmacher, called the delayed publication an act of cowardice and cynically declared that what years ago would have caused great damage to the State now had deteriorated into something meaningless, anachronistic, and almost ridiculous (87).

\footnotetext{
${ }^{8}$ Ulrich Greiner, "Mangel an Feingefühl," reprinted in Thomas Anz. Ed."Es geht nicht um Christa Wolf." Der Literaturstreit im vereinigten Deutschland. Frankfurt a. M.: Fischer, 1995. (66-76); Frank Schirrmacher.'Dem Druck des härtern Lebens standhalten." Ibid, 77-89. Thomas Anz and also Karl Deiritz and Hannes Krauss in their book, Der deutsch-deutsche Literaturstreit oder ,Freunde, es spricht sich schlecht mit gebundener Zunge " (Hamburg: Luchterhand, 1991) provide copies of original articles and commentaries as well as an analysis of the different phases of the debate. Especially useful and informative is also Andreas Huyssen's article, "Das Versagen der deutschen Intellektuellen. Verschiebebahnhof Literaturstreit," in Deiritz and Krauss, pp. 78-101.

${ }^{9}$ The most prominent among the critics were Frank Schirrmacher (Frankfurter Allgemeine Zeitung) and Ulrich Greiner (Die Zeit), both accusers of Wolf, while Wolfram Schütte (Frankfurter Rundschau) and Uwe Wittstock (Süddeutsche Zeitung) came to her defence.
} 
Ever since the late sixties, the West had been celebrating Wolf as one of the GDR's most accomplished writers, partly because of the high aesthetic quality of her works but also because of her criticism of her country's government. But suddenly the tables were turned. Now her lack of action was interpreted as a sign of secret collaboration with the repressive totalitarianism of GDR government, and some even defamed her a Staatsdichter. What was supposed to be a discussion about a work's literary merit quickly became a personal attack on Christa Wolf and a disparaging of the literary merit of her oeuvre in general. The point was not to judge Wolf's performance as a writer but her ideology and her political engagement (or lack thereof). Immediately after the appearance of Schirrmacher's provocative article in the Frankfurter Allgemeine Zeitung, several other critics and some of Germany's most well known political writers came to Wolf's defense; soon, the literary community was split into two groups. ${ }^{10}$ Those siding with Wolf argued that one must not underestimate the complex and difficult situation of politically engaged writers in the former GDR, and especially of writers who, like Christa Wolf, kept believing in the possibility of a better, more democratic form of socialism. In order to be heard, these writers were constantly walking a tight rope between criticizing the country's government while at the same time making sure that their works would reach their intended audience. Interestingly, the factions were not split between East and West but unevenly distributed, with most participants coming from the Federal Republic, however (Thomas Anz, "Eskalation des Streits," 94).

${ }^{10}$ Among those who defended Wolf were critics Friedrich Dieckmann, Volker Hage, Martin Arens, and Fritz-Jochen Kopka, as well as writers Helga Königsdorf, Walter Jens, Jurek Becker, and Günter Grass. 
Phase Two

In October 1990, just a few months after the controversy about Christa Wolf had finally quieted down, the debate started anew, only this time, West Germany's critics also directed their polemics against their own literary elite, the writers of the so-called engagierte Literatur. In a sense, this turn in the Literaturstreit had its source in one of Schirrmacher's earlier responses to the publication of Christa Wolf's Was bleibt. At the end of his June 2, 1990, feuilleton contribution in the $F A Z$, Schirrmacher had already branched out to a general critique of politically engaged literature in both German states. He noted that writers acting as spokespersons for a particular ideology or political position (which was Christa Wolf's crime) reminded him of Germany's most recent past when the country's intellectuals had failed to recognize the dangers of totalitarianism. To him, "Der Fall Christa Wolf” was proof that the intellectuals in both Germanys still hadn't learned their lesson. Ulrich Greiner quickly chimed in. In his feuilleton contribution with the telling title „Keiner ist frei von Schuld,” published in Die Zeit on July 27, 1990, Greiner argues that East German intellectuals were partly responsible for the second German catastrophe - after that of National Socialism now that of Stalinism. And once again the question is one of overcoming the past and taking responsibility. Only this time, he notes, the country's intellectuals are both the accuser and the accused (Anz, 179/80).

Again, it was politics and not literature that led to a resurgence of the Literaturstreit. The new debates were a direct response to the most recent political events in the East. Many of the GDR's most prominent writers and intellectuals together with West Germany's left-wing intellectuals and political writers publicly called for 
preserving the GDR's political autonomy. Opposing the idea of East Germany simply acceding to the West, they suggested that the country's government should be reformed into a democratic socialism — the so-called "dritte Weg." They were in the minority, however. Most GDR citizens were opposed to the idea of a new socialist government and were calling for a political reunification with the West. ${ }^{11}$

During the nineteen-sixties and seventies in particular, politically oriented literature had been a prominent feature in West Germany's literary scene. Some of the most renowned post-war writers, such as Heinrich Böll, Günter Grass, Hans-Magnus Enzensberger, and Peter Weiss had chosen ethical, political, and humanitarian issues as the focal point of their writing. They had openly criticized their country's gradual drift towards conservatism, conformism, and political intolerance, and their works had strong moral and political undertones. Ultimately, though, their political engagement did not bear fruit, just as was the case with East Germany's political writers. Pointing out these parallels, Schirrmacher argued that politically engaged literature was simply a case study in misguided thinking. Ulrich Greiner quickly followed suit. Like Schirrmacher, he claimed that during the last forty years, writers in both Germanys had placed too much emphasis on ethical and moral issues while neglecting literature's aesthetic dimensions. Greiner used Karl Heinz Bohrer's highly pejorative term Gesinnungsästhetik as the label for politically engaged literature, and hurried to add — not without a touch of irony — that Gesinnungsästhetik was “das gemeinsame Dritte der glücklicherweise zu Ende gegangenen Literaturen von BRD und DDR” (,Die deutsche Gesinningsästhetik,” in

${ }^{11}$ As to be expected, the "dritte Weg" was voted down when, on August 22, 1990, the GDR Volkskammer decided in favor of a united Germany under the existing government of the Federal Republic. 
Anz, 213). ${ }^{12}$ Gesinnungsästhetik, Greiner noted, was the predominant trait of German literary production - in the GDR as a matter of fact, but also in the Federal Republic (214). Its result was relegating literature to a series of political and moral statements. Such arguing about the relationship between ethics and aesthetics was of course not a new topic in Germany's literary history. Already in the $18^{\text {th }}$ century, Friedrich Schlegel had been highly critical of Schiller's insistence that art should have a universal, political, and/or metaphysical referent. Then, in the early $20^{\text {th }}$ century, Nietzsche and later Adorno rekindled this debate and expressed the same kind of skepticism towards judging literature according to ethical and moral standards, and now, at the end of the millennium, the question about the purpose of art was under discussion once again. But there was an interesting ironic twist to the current debate. Was it not Greiner, now the most vocal proponent of the aesthetics camp, whose criticism of Christa Wolf's aesthetics in Was bleibt had been informed by moral and political arguments rather than by an objective discussion of the work's possible aesthetic flaws? Furthermore, with the changed political relationship between the two Germanys, the political message in Wolf's novel, instead of granting her the usual Bonuspunkte, suddenly became the reason not only for the book's violent rejection but also for numerous personal attacks against Wolf. And there was one other interesting turn. Appealing to a reader's moral, political, and social responsibilities had always been the main strategy with which Germany's left-wing writers had defended the validity of their literary works. Now, however, the table was

\footnotetext{
${ }^{12}$ Gesinnungsästhetik, according to Bohrer, was the label for an aesthetics that emphasized moral and political content-matters of the writer's basic convictions and views, Gesinnung - at the cost of formal and structural experimentation.
} 
turned, as the conservative enemy adopted their argumentation and used it against them (,Eskalation des Streits,” 97).

Phase three

One year later, during the last months of 1991, after the ethics versus aesthetics debate had calmed down, the Literaturstreit flared up once again. The cause was the discovery that several members of GDR's literary elite had at some point in their past collaborated with the Stasi. West Germany's literary circles were outraged and filled with disbelief. ${ }^{13}$ These new discoveries gave the ethics/aesthetics controversy new meaning and further strengthened the anti-intellectual climate in the West. And once more, it was Christa Wolf (together with Heiner Müller) who was considered the main culprit. Subjected to a kind of public cross-examination, she had to experience (again) how sensationalism and polemics led to a perversion and distortion of what had really happened. ${ }^{14}$ Had the idea of East German dissident writing been nothing but a myth, merely a fabrication (wishful thinking) of Western ideology? And more importantly, was it the case that in the GDR even subversiveness was politically staged and controlled by the government? With this new information, the task of evaluating GDR-literature was

${ }^{13}$ Especially shocking was the fact that such well-known, critical, and dissenting writers such as Christa Wolf, Monika Maron, and Heiner Müller belonged to this group of former Stasi informants. But by far the greatest shock of all was the news that Sascha Anderson and several members of East Germany's most avant-garde and subversive literary scene, the writers of the Prenzlauer Berg, had also been collaborating with the Ministry for State Security.

${ }^{14}$ In the "Nachwort" to his book about the literary battle, Anz points out that the tone of this new debate very much resembled that of a criminal investigation. As before, the real issue was political. "Wieder wurde dabei ein Stück DDR-Kultur entwertet, das, ..., vormals im Westen hohes Ansehen genoß. Und wiederum wurde auf dem Gebiet der Literatur stellvertretend über Probleme der 'Vergangenheitsbewältigung' gehandelt, . .." (273). 
reaching a new level of complexity. How could one praise writers for their outspokenness and their courage to criticize a defective political system when these writers' past actions give the lie to their speech? Finally, it all boiled down to the question of how much one should or could let a writer's personal life and political orientation affect the evaluation of her or his work. Considering the history of the Literaturstreit, this was not a new issue. Already a year earlier, in his essay "Die deutsche Gesinnungsästhetik," Ulrich Greiner had cautioned that if too much emphasis were given to the political and moral message of a literary text, then the literary work and its author's moral beliefs would become inseparable. Such merging of a writer's art and her/his personal life, Greiner argued, would deprive the work of that which is its most defining characteristic, its aesthetic qualities.

It is important to note that neither Schirrmacher or Greiner nor any other critic on their side of the debate was an advocate of the l'art pour l'art approach to literature, nor did they ever promote a categorical separation of the moral and political from the aesthetic. In his Gesinnungsästhetik essay, for example, Greiner affirms the notion of a connection between art and morality while referring to George Steiner's ideas about the relationship between art and life/reality. Greiner writes that a piece of art is different from all other human endeavors, in that its effect is morality (“Aus ihm folgt Moralität”). In art morality is not announced or talked about in some practical instruction or general axiom. Rather, it is evoked through art's singular effect on the recipient-“der Augenblick jener höchsten Aufmerksamkeit, die den Leser ein für allemal verändert” (Anz, 213).

Once again, one is struck by the contradictory nature of the argumentation. Had Greiner taken his own words seriously and if it really were just the literary work and its 
effect on the reader that mattered, then why did he and his fellow debaters let their discussions be tainted by arguments concerning a writer's personal life? Furthermore, talking about engagierte Literatur in the early 1990s was strangely anachronistic. With the emergence of post-structuralism and postmodernism in the mid to late seventies, the new generation of writers was more interested in experimenting with unconventional literary forms than with criticizing the government. Writers in both parts of the country had turned to global issues, such as modern technology and nature, the role of woman in a man's world, and the dangers of reason. For more than a decade, literature had been a place for self-exploration and self-reflection, but not for dealing with matters of politics or ideology. Those who participated in the various debates of the literary battle were well aware of this incongruity in their argumentation. They knew that the real topic to be discussed was cultural politics and history, and at the heart of it all was the question of German identity. In this sense, the question underlying the discussions about the supposed literary value of literature written in the former GDR was really the question about how to deal with the cultural and political heritage of the previously estranged neighbor in the new Germany's common but separate history.

This point was also emphasized by critic Irene Heidelberger-Leonard, one of the opponents of the Schrittmacher/Greiner faction. In her essay "Der Literaturstreit-ein Historikerstreit im gesamtdeutschen Kostüm,” she points out important similarities between the Literaturstreit of 1989-91 and the Historikerstreit in $1986 .{ }^{15}$ Both events dealt with issues of Germany's historical consciousness and with the problem of

\footnotetext{
${ }^{15}$ Heidelberger-Leonard's contribution is reprinted in Karl Deiritz, Hannes Krauss, 69-77.
} 
overcoming the political trauma of the past-National Socialism in the case of the Historikerstreit and real existierender Sozialismus in the case of the GDR's socialists and both are examples of the Federal Republic's offensive efforts to confirm and strengthen its own historical and political understanding (74). On the one hand, forty years of GDR history could not simply be erased; on the other, not everyone shared this history. Though the debates of the literary battle were mostly about the past, their real purpose was to help interpret the present and provide direction for the future. The true point of disagreement, then, was not about the relationship between literature and politics, but about the fate of the literature from the former GDR. Heidelberger-Leonard argues that the discussions about GDR-literature are just an excuse for political cleansing, and the ultimate purpose of these debates about revising the two German post-war literatures is to diminish the importance (entwerten) of literature written in the former GDR (69). Though Greiner admitted that the issue wasn't really Wolf's Was bleibt and that the novel had merely served as a catalyst, he preferred to interpret the rationale behind the debates in more general terms. He claimed their purpose was not the $d e$ valuation of literature from the former GDR, but a re-evaluation of the post-war literature from both Germanys with the goal of finding a new direction for reunited Germany's future literary history. In his Gesinnungsästhetik essay, he describes the situation as follows:

Es geht um die Deutung der literarischen Vergangenheit und um die Durchsetzung einer Leseart. Das ist keine akademische Frage. Wer bestimmt was gewesen ist, der bestimmt auch, was sein wird. Der Streit um die Vergangenheit ist ein Streit um die Zukunft. (Anz, 208) 
Thus, the Literaturstreit was a first step in the settling of accounts between the two German literatures. Its heated debates, their polemical tone, and their repeated flaring up all attest to the seriousness of the cultural crisis and the sense of disorientation Germany experienced immediately before and after its unification. To simply erase the last forty years of GDR-literature would mean denying people from the former GDR their own literary past and part of their cultural heritage. Such a radical disposal of the GDR's literary heritage would be premature, to say the least. Wolfram Schütte from the Frankfurter Rundschau, one of the more detached participants in the debates, pointed out that a radical historization such as the sudden collapse of a whole epoch requires historical remembering in order not to deteriorate into a case of blind and impulsive sophistry. ${ }^{16}$ Thus, the lesson to be learned from the literary battle of the earlier 1990s is that in order to transform the two Germanys into an integrated whole, it is absolutely necessary to acknowledge the fact that for forty years there had been two German histories - and by implication also two different literatures. How much of the former GDR's culture and history will become part of the new German identity, only time can tell.

\section{Nationhood, Politics, and Aesthetics}

The prospect of a common German literary history meant that long established approaches to and also prejudices about literary production in the GDR had to be carefully examined and revised. The first, and certainly most important, step in such an

${ }^{16}$ Schütte writes, "Die radikale Historisierung bedarf auch historischer Erinnerung, um nicht blind-wütig der unverhofft \& unerwartet eintretenden Versuchung eilfertiger Besserwisserei anheim zu fallen." ("Reiß:Wolf. Zu einem Eil-Verfahren beim Umgang mit der DDR-Literatur," in Thomas Anz, 113). 
endeavor is to arrive at a clearer understanding of the phenomenon GDR-literature. This means first of all acknowledging the phenomenon's complexity by revising the notion that politics and ideology were the driving force behind literary production in the GDR, and it also means paying closer attention to the formal peculiarities of this literature. Finally, there is the question about the phenomenon's temporal parameters. This issue will be discussed in the concluding chapter of this project.

\section{A. Literature and Nationhood}

From the very beginning of literary production in the former GDR, one of the complicating factors concerning its status as a German literature was how throughout German history the idea of a shared language and culture was essential for establishing Germany's sense of nationhood. Sharing a common culture had always played a decisive role in the formation of national identity.

Unlike with any other European nation, political fragmentation had always been one of the defining characteristics of Germany even before its most recent division in 1949. During these times of political dividedness, the concept of Germany as Kulturnation helped strengthen people's sense of national identity. ${ }^{17}$ Not political unity, but participating in the same customs and traditions, speaking the same language, and sharing a common literary heritage provided a feeling of cultural cohesiveness. The most important building block in the constructing of Germany as a Kulturnation was literature.

${ }^{17}$ According to Stephen Brockmann, it was first Johann Gottfried Herder who, during the late $18^{\text {th }}$ century, "[defined] national identity based on common language, tradition, and customs." From then on, and in particular during the $19^{\text {th }}$ century, the "sense of German national consciousness" developed into the unifying element in the development of Germany's nationhood (German Literary Culture at the Zero Hour, 7). 
It served as collective memory, while sharing the same language was a means of preserving and spreading a sense of national identity. ${ }^{18}$ Thus, during the first decade of Germany's most recent division in 1949, it was again this idea of Germany as Kulturnation and the two countries' cultural connectedness that the Federal Republic used as the primary argument against the political division. At that point in time, it did not matter to the West that the other Germany was governed by a totally different political system and no longer shared its ideology. As time passed, however, and especially with the emergence of the Cold War and the building of the Wall in 1961, it became obvious that this idea of Germany's cultural unity was no longer tenable. Not only had different social norms and customs been developing in the East, but also culture was tightly linked here to matters of ideology and government politics. With the Fall of the Wall and German unification, however, a renewed interest in the topic of national identity suddenly emerged, especially in the former Federal Republic. In the eastern provinces, by contrast, mostly in reaction to their rapid Westernization, the awareness of having developed a different cultural identity began to surface. Thus, in the united Germany, the idea of one German national identity had suddenly become questionable. Thus, after political unification, it was exactly this issue of culture and cultural heritage that alienated the two Germanys from each other.

The two reasons for the tension and the resentment between the two German states after 1989 were the suddenness of the GDR's downfall and the speed with which

\footnotetext{
${ }^{18}$ For a more detailed discussion of the importance of literature for the creation of a national identity see Anton Kaes, "Literatur und nationale Identität: Kontroversen um Goethe 1945-49," in Albrecht Schöne. ed. Kontroversen, alte und neue Akten des VII. Internationalen Germanisten-Kongresses Göttingen 1985. Vol.10. Göttingen: Niemeyer, 1986. 199-206.
} 
the political reunification was accomplished. While it is beyond the scope of this project to elaborate on the whys and hows of what happened between November 9, 1989, and October 3, 1990, a few general comments about the relationship between the two Germanys between 1949 and reunification will reveal the complexity of the situation in 1989 and shed light on the difficulties concerning the country's cultural unification.

After the GDR declared its autonomy in 1949, the divided Germany came to represent the two major, conflicting ideologies and economies of the Western hemisphere, capitalism and communism. Especially during the 1960s, Cold War antagonisms further deepened the rift between the two German states. Each state proclaimed itself as the preserver of true German cultural heritage while also insisting that its cultural heritage was different from that of the other. As Stephen Brockmann remarked so poignantly, "precisely because of the essential similarity between the two Germanys, each state had to conceive of itself as fundamentally different at every level from its counterpart" (Literature and German Reunification, 8). Each German state thus created an image of the other that would function both as foil and incentive for its own political system and ideology as well as for its culture. Especially in the former GDR, literature played a central role in establishing the country's cultural autonomy and strengthening its (cultural) independence from the West. Though the relationship between the two countries began to normalize during the 1980s, some of the old prejudices resurfaced with unification. A new mental wall (die Mauer im Kopf) was now dividing the reunited country, and ultimately, it was this inner dividedness that turned the Germanys' cultural unification into such an emotional undertaking. 


\section{B. Literature, Politics, and Ideology}

Any attempt at identifying certain defining properties of literature written in and about the former GDR has to be prefaced by the statement that there never was such a thing as $a$ GDR-literature. Right at the beginning of the introduction to his Kleine Literaturgeschichte der DDR, literary historian Wolfgang Emmerich, one of Germany's foremost specialists on GDR-literature, warns his readers of how difficult it is to understand what exactly the defining characteristics of GDR-literature are composed of. He writes that here one is dealing with a phenomenon, "das weder mit den Gesetzen der reinen Logik, noch mit innerliterarischen Maßstäben allein zu erfassen ist, sondern eher mit sehr menschlichen Dingen zu tun hat" (11). Not only did there exist during the forty years of Germany's division there existed an eastern and a Western notion of GDRliterature, but also, in both countries, the idea of what constituted this literature kept changing and evolving in response to the political climate between and also within these two countries. In other words, as Emmerich so carefully describes, even while the GDR still existed, there never was a clear understanding of which literary works deserved to be accepted into the country's literary canon. ${ }^{19}$

In the former GDR, literature (and art in general) was to be first of all an instrument for ideological indoctrination. Literary production was subjected to numerous regulations and restrictions imposed by the State and the Socialist Unity Party. According

${ }^{19}$ In his book Gehen oder Bleiben? Literatur und Schriftsteller der DDR zwischen Ost und West, critic René Granzow, too, gives a very detailed account of the complexities and contradictions one encounters when looking for meaningful criteria with which to fill the term "DDR-Literatur" (33-40). The book itself, an investigation into why certain GDR writers moved to the West and others decided to remain in the East, provides valuable insight into how East German writers dealt with censorship and in general with the repressive climate in their country. 
to party policy, literature had three fundamental functions: to battle Fascism, to help build a new, democratic society, and to preserve as well as continue the country's classical cultural heritage (Kulturerbe). According to the Socialist Unity Party's cultural politics, these goals could only be reached with a literature that gave an objective representation of reality and adhered to the tenets of socialist realism. Socialist realism as an aesthetic program rejected formalists' preoccupation with the formal aspects of art and had its origin in the works of $19^{\text {th }}$ century Russian realists. The concept was based on the idea that literature had to be a truthful, historically accurate, and objective mirror of everyday life. The basic requirement was a positive hero who is dedicated to the betterment of society. Though a specific literary work may depict conflicts and various hardships of working class life, its goal is not to criticize but inspire. The protagonist's life story was to set a positive example of what it meant to be a dedicated socialist and show the importance of individual sacrifice for ensuring society's revolutionary development. As the nation's educators (engineers of the soul, as Stalin called them), writers in East Germany had two main tasks. They were to be directly involved in the collective building of a socialist utopia and to function as mediators between the government and its people..$^{20}$ The goal was to create a nationale Arbeiterliteratur (a national workers' literature), which was to further the political education of the working class by providing

\footnotetext{
${ }^{20}$ In the Federal Republic, on the other hand, political engaged writers regarded it their duty to protect democracy and preserve the rights of individual freedom. As the "conscience of the nation," they were always highly critical of concepts such as nationhood, national identity, and national pride. Particularly during times of inner political crisis, the criticism of government policies inspired vehement political and ideological controversies. Furthermore, in West Germany, showing national pride or national spirit was deemed highly suspicious because these concepts were tainted by memories of the Nazi's exploitation of people's nationalist sentiments. As a people that had been involved in some of the most inhumane acts against human kind, West Germans felt they had no right to exhibit national pride.
} 
positive role models and by helping close the gap between the classes. Aside from literature's political and ideological mission, during the early years of the GDR's existence and especially after the building of the Wall in 1963, it also was to help strengthen the citizens' national consciousness and provide a new sense of identity. Through a rigid system of censorship and through close surveillance of its writers (especially of those who had a history of disagreeing with party politics), the Socialist Unity Party exercised tight control over the country's literary scene. In order to get accepted into the official literary canon, a work had to fulfill two main prerequisites: promote socialist ideology and adhere to the aesthetic guidelines of socialist realism.

Because of the direct connection between literature and politics/ideology changes in country's political climate and in its relationship with the West also directly affected the norms regulating the publishing industry. Confronted with the various failures of its cultural politics, the socialist party was constantly adjusting and/or modifying its directives, as can be seen in the case of the Bitterfelder Weg program, for example.

In order to strengthen the link between literature and politics and have writers more actively participate in the building of the socialist state, the functionaries of the Socialist Unity Party, in their $5^{\text {th }}$ assembly in 1958 , decided that more rigorous measures needed to be taken to close the gap between art and life. To bring the nation's writers closer to the life of the working class, it was decided that writers were to spend a certain amount of time working in the country's factories. This would give them first-hand experience with the working class and thus provide them with new socialist content for their works. Furthermore, writers could also support those workers who were interested 
in literary production. ${ }^{21}$ Thus, on April 24, 1959, the East German publishing company Mitteldeutscher Verlag arranged a conference in the VEB Chemiekombinat in the town of Bitterfeld. Attending this conference were writers, workers' correspondents, and those workers who aspired to be writers. It soon became obvious, however, that the party's plan to do away with the separation between professional artists and laymen was unrealistic. Not only did the country's writers feel the program infringed on their artistic freedom, but the initial enthusiasm among the workers quickly faded, and party officials had to admit the futility of the project. With the building of the Wall and the new economic system, the interest in the Bitterfelder Weg program began to wane, and by the late 1960s, this rather exotic mass-cultural initiative, as Emmerich so adequately describes it, was a thing of the past (Kleine Literaturgeschichte, 130).

During the late 1950s and the 1960s, when the political tensions between East and West Germany were at their peak, literature in the GDR was more strictly regulated and controlled than in the early seventies, when Honecker temporarily loosened government regulations, or in the mid to late eighties, after Gorbachev's institution of glasnost. In short, even among those who made the official rules and regulated the country's literary production, the expectation of what so-called GDR-literature should be was constantly being revised and adjusted. This means that even if one were to think of GDR-literature in terms of literary works that conformed to the standards set by the Socialist Unity Party, one would be at a loss to specify this literature's defining properties over time.

${ }^{21}$ The program was called Bewegung schreibender Arbeiter and had as its motto, "Greif zur Feder, Kumpel, die sozialistische deutsche Nationalkultur braucht dich!" (Take a hold of your feather, buddy, German socialist national culture needs you.) 
This imposed connection between literature, political doctrine, and ideology in the former GDR also caused several other complications. For example, what place was to be assigned to literary works by writers who refused to conform to the party's aesthetic doctrines and/or directly criticized the system by showing its flaws and failures? Many of these works were censored in the GDR but were published in the West, where they were considered as representative of GDR-literature. Monika Maron's novel Flugasche is a case in point. The novel was published in 1981, and only in West Germany, but because of where Maron lived and because of the novel's subject matter, the work was considered GDR-literature. This question became even more topical after the mass exodus of GDR writers in response to Wolf Biermann's exiling in 1976. Sarah Kirsch, Monika Maron, Uwe Kolbe, and Wolfgang Hilbig are the most well known among them. Though these writers no longer lived in the GDR and published exclusively in the West, the GDR was where they grew up and they continued to write about life in the GDR. Moreover, their works greatly influenced young upcoming writers in the East and thus were contributing to the development of an East German literary tradition. Were the works of these writers to be considered part of GDR's literary canon? In the West they certainly were, but as far as East German functionaries were concerned, they certainly were not. It is clear, then, that throughout the GDR's existence there was a West and an East German version of the GDR's literary history, and ironically many of the country's most acclaimed writers were excluded from the official East German version.

One other interesting phenomenon needs to be mentioned, one that came to light only after reunification: works that, though written while the GDR still existed, were not published until after its demise. According to their subject matter these works should be 
included in the former GDR's literary canon. ${ }^{22}$ There is of course also the question of the so-called post-GDR GDR-literature, but this phenomenon is part of a different topic.

Not to play the devil's advocate, but the notion of (politically and ideologically) affirming or dissenting literature is highly problematic in itself. Whether or not a work can or should be labeled politically subversive depends on a variety of factors. I mentioned earlier how changes in the former GDR's political climate affected the notion of what was formally, politically, and ideologically inacceptable. Works that passed censorship in the early seventies or mid-eighties at other times might not have received permission to be published. Aside from the fact that there is always a personal and subjective component to evaluating ideas in a particular piece of literature, dissent can also be a matter of degree, and what one reader may interpret as deliberate subversiveness or political opposition, another may interpret as mere ironic play. Since literature works on different levels of meaning, there is not always a clear dividing line between affirmation, criticism, and dissent. Furthermore, criticism does not necessarily imply opposition or rebellion. Especially during the first two decades of the GDR's history, the country's politically engaged writers such as Christa Wolf, Heiner Müller, or Günter de Bryn considered their criticism as constructive-as a way of furthering the advancement of real existierendem Sozialismus - and not as an expression of antagonism.

Similarly in the Federal Republic, the notion of what constituted GDR-literature kept being revised during the four decades of the GDR's statehood. As Wolfgang Emmerich pointed out, during the first decade of Germany's division, the more

${ }^{22}$ Reinhard Jirgl, winner of the 2010 Büchner Preis, is perhaps the most well known representative of this group of writers. After the Fall of the Wall he surprised the literary world with volumes of unpublished material of outstanding literary quality. 
conservative literary critics in particular insisted on preserving the notion of one German literature (Kleine Literaturgeschichte, 11). During the sixties, with the increase in Cold War tensions and the gradual estrangement between the two German states, there was a consensus that in the East, another German literature was being written. For many West German citizens, this emerging GDR-literature often was the only way to get a sense for what the life in the East might be like, not to mention the fact that it also assured those in the West that they were living in the "better"-economically and technologically more advanced, more prosperous, and above all freer-of the two states. Western critics soon began to notice that the East was producing a number of aesthetically remarkable works. These works were well received in the West and they also found a large readership. Thus authors such as Uwe Johnson, Christa Wolf, Günter de Bryn, Heiner Müller, and Volker Braun were quickly considered important literary figures in the "Western" canon of GDR-literature.

In general, the Western canon of GDR-literature was selected according to a number of exclusive political, ideological, and to a somewhat lesser extent, aesthetic criteria. Systemkritik (criticizing the political system) and dissidence were key aspects when it came to judging a literary work from the former GDR. At the same time, the other GDR-literature, the one officially sanctioned by the State, was branded in the Federal Republic as literature of political indoctrination. It was automatically deemed aesthetically inferior and its existence was generally ignored. One of the main reasons for the diverging approaches to literary production in the Democratic Republic is a difference in perspective. As described earlier, in the former GDR, literary production was prescriptive in the sense that it was bound to specific norms and regulations and that it 
had a clearly defined social function. It was seen in terms of a process and was thought of as a literature in the making. In the pre-unification West, on the other hand, the term GDR-literature was used descriptively, and beginning with the late sixties, it was reserved primarily for the works of politically critical or dissenting writers. In fact, the one aspect that both countries seemed to agree upon, was the notion that political content and ideology were of primary importance in the evaluation of GDR-literature.

It is certainly the case that the officially imposed symbiotic relationship between politics and aesthetics, which marks the very beginning of GDR-literature and also to a certain degree affected its development, cannot be ignored, especially since it is one of the main reasons for the term's vagueness. Furthermore, as Emmerich has pointed out, ignoring this connection between politics/ideology and literature would be historically wrong since even those writers who tried to avoid the party's prescriptive norms by writing against them or by invalidating them in some sense still remained affected by them (19). Generally speaking, however, the influence of ideological premises and political propaganda must not be overrated. Julia Kormann, for example, points out the importance of a writer's experienced reality on her/his work, and this includes factors such as her/his social reality, personal experience, and the purpose attributed to her/his work (Literatur und Wende, 38). According to Kormann the determining factor concerning life in the other Germany was an ever-present contradiction (ein Realitätswiderspruch) between a reality propagated by the State and the reality experienced by the country's citizens. ${ }^{23}$ The awareness of a clash between these two

${ }^{23}$ The awareness of such a Realitätswiderspruch is one of the reasons why so many writers from the former GDR and the new East are resorting to various kinds of language play and ironic undermining of surface reality. 
realities, public and private, is according to Kormann what most shaped literary production in the former GDR. This is not a political issue but one related to human experience. Indeed, ever since German unification, critics have been making a consolidated effort to give literature from the former GDR a new reading - one that regards texts as individual productions with certain aesthetic characteristics rather than as responses to certain political directives.

\section{Characteristic Themes and Writing Styles of GDR-literature}

Today critics agree about how problematic and limiting it is to consider political and ideological content as the essential quality of GDR-literature, yet there is, to my knowledge, no comprehensive study of what one could consider the distinctive themes and writing styles of GDR-literature. I do not intend to fill this gap entirely since this would be beyond the scope of my project, but in connection with my argument about a Weiterschreiben of GDR-literature after the Fall of the Wall, I shall provide a brief description of some of the most distinctive characteristics of the phenomenon GDRliterature. These are not exclusive to the GDR's literary scene, however. They only demonstrate that certain themes, certain ways of using language, and certain literary forms are more prevalent in literary works about and from the former GDR than in those written by West German writers. Despite travel restrictions, censorship, and the government's tight control over the country's literary production, writers in the former GDR did not work in a cultural vacuum but were well aware of general literary trends and developments. The difference between literature produced in the GDR and in West Germany is most of all one of perspective and is the result of the country's unique history 
and socio-political environment. In other words, politics does play a role, but only in so far as its effect on daily life in the GDR gave shape to certain viewpoints and attitudes and elicited particular kinds of responses. Reflecting the problematic nature of the phenomenon GDR-literature, the categories I am about to introduce are meant to be descriptive and to outline its inherent complexities and contradictions. In the introduction to the "erweiterte Neuausgabe" of his Kleine Literaturgeschichte, Wolfgang Emmerich mentions the necessity of giving a differentiated and skeptical description of the ambiguities surrounding the development of GDR-literature. ${ }^{24}$ He writes, "Wer an Multiperspektivität interessiert ist . . . wird auch den Begriff DDR-Literatur nicht künstlich eindeutig machen, sondern beharrlich offenhalten" (21). ${ }^{25}$ Considering the recent phenomenon of a post-GDR GDR-literature - a topic to be discussed in more detail later - at this point in time, it is still too early to arrive at any definite conclusion. To what extent the unique history of the GDR and its particular socio-cultural environment invited certain kinds of themes and subject matters and inspired certain ways of writing that are favored among the country's writers, will be the topic of the following pages. ${ }^{26}$

${ }^{24}$ In this introductory chapter, Emmerich gives an excellent account of the different complexities and ambiguities surrounding the term GDR-literature.

${ }^{25}$ Supporting Emmerich's position, Ursula Heukenkamp argues "DDR-Literatur einstweilen nicht als definiert, sondern als problematisch [darzustellen]." ("Eine Geschichte oder viele Geschichten der deutschen Literatur seit 1945? Gründe und Gegengründe," 31)

${ }^{26}$ The following pages are meant merely as a general survey. The point is not literary analysis or comprehensiveness but simply to provide a few examples with which to illustrate the characteristic features of each category. The selection of works reflects my personal taste; there certainly are other fictional narratives that could have been mentioned in connection with the themes and writing styles I listed. 


\section{A. A Regional Literature}

Essential to the uniqueness of GDR-literature is how it is historically and geographically bound. The term is first of all used for literature produced in the GDR during the forty years of the country's existence. This includes works that dealt with historical, political, and social phenomena specific to Germany's pre-WWII eastern provinces including those territories that once were settled by ethnic Germans. ${ }^{27}$ As Heiner Müller once so poignantly remarked, "Der Aufenthalt in der DDR war zuallerst der Aufenthalt in einem Material" (quoted in Kleine Literaturgeschichte, 27). In other words, the geographical entity GDR served as a kind of poetic landscape the country's writers described, responded to, and interpreted in a number of different literary forms and writing styles. When talking about literary production in the two Germanys after the historical turn, David Roberts, in Schreiben nach der Wende. Ein Jahrzehnt deutscher Literatur 1989 - 1999, points out that West and East German writers have totally different "Erzählinteressen" which are grounded in their fundamentally different experiences of the historical turn. The same is certainly true for the decades of the GDR's existence. The establishing of the GDR as a socialist state and as a result of its alliance with the USSR led to decisive changes in the country's socio-political reality and cultural

\footnotetext{
${ }^{27}$ Since many refugees from these regions settled in the former East Germany, their history, which is one of subjugation, persecution, and expulsion, became part of East German history and has been written about predominantly by East German writers. One the more highly acclaimed writers in contemporary East Germany's literary scene who deals with the fate of these political refugees is Reinhard Jirgl. His novel Die Unvollendeten (2003), for example, is a gripping and quite disturbing family saga that covers fifty-five years of East German history. It tells about the life of four women who, after having been expelled from their home in the Sudetenland in 1945, are trying to get established in the Altmark, a region in northern Saxony.
} 
politics as a result of which the two Germanys began to develop in dramatically different directions - politically, historically, and culturally. ${ }^{28}$

By calling GDR-literature a regional literature, I am not implying that literature from the former GDR is merely a reaction to the country's specific cultural and political phenomena, and I am certainly not advocating an approach that prioritizes content or promotes the idea of literature as a mere copy of reality. At the same time, however, I agree with Wolfgang Emmerich who argues that a literary text is not created in a cultural vacuum. In some ways, literature is always an expression of its author's experience in a specific society at a certain time. ${ }^{29}$ There is no causal connection between art and life, but there is a dialectical relationship between the literary work and the place and time it was written. In defense of regional literature, Norbert Mecklenburg emphasizes that one way in which regional literature attains a significance that reaches beyond its geographical boundaries is exactly by being so firmly rooted in the specific. He argues, [d]er Doppelcharacter von Literatur als Mimesis und Poesis macht es möglich, im gelungenen Kunstwerk einen regionalen Weltbezug in einer Weise aufzuheben’, daß er in der poetischen Verfremdung negiert und gleichwohl bewahrt erscheint. . . . Regionalität und Universalität der

${ }^{28}$ In his essay, "Verfremdete Nähe - Aspekte des Problemfeldes Literatur und Region',"Norbert Mecklenburg mentions as a characteristic trait of regionalism certain differences in historical development and a general awareness of being different, both of which most certainly apply to the former GDR and also to life in the post-Wende eastern provinces (340).

${ }^{29}$ Emmerich writes, "[Literarische Werke] freilich sind . . . Ausdruck der lebensgeschichtlichen Erfahrungen von Autoren in einem bestimmten Gesellschaftssystem" (Kleine Literaturgeschichte, 240). 
Literatur können in fruchtbarer polarer Spannung zueinander stehen, . ... $(347)^{30}$

Though all of the works included in the category GDR-literature are geographically and historically bound, there are certain texts in which the regional component is particularly emphasized. For these texts critics generally use the label local color narratives and in German they are often called Heimatliteratur. Narratives of that kind stand out because of their authenticity and the realism of their descriptions. They capture with great accuracy and often in minutest detail the characteristic features of a particular place and its people. When I talk about GDR Heimatliteratur, I do not mean the kind of literature that uncritically idealizes life in the country and whose primary purpose is to entertain. I am speaking of a literature that in addition to being authentic is also aesthetically sophisticated and that ultimately transcends the specific as it takes on broader significance. Among the more highly praised writers of this kind of regional literature are Erwin Strittmatter and Johannes Bobrowski.

One of Strittmatter's best received and widely discussed fictional narratives is his novel Ole Bienkopp (1963), which is often considered the prototype of the GDR Bauernroman. With great detail and keen precision Strittmatter describes the natural environment surrounding the fictional village of Blumenau and the different aspects of the local farmers' daily routine. While providing valuable insight into the problems and conflicts that these farmers are experiencing as a result of the country's agricultural reforms during the early nineteen-fifties, his novel is also a moving study of human

\footnotetext{
${ }^{30}$ Mecklenburg calls this complex relationship between the particular and the universal phenomenon "verfremdete Nähe," an idea that, as will be elaborated on later, echoes Kerstin Hensel's notion of "erfahrene Erfindung."
} 
nature. With his true-to-life descriptions of the toils and hardships of country life during the GDR's Aufbaujahre, Ole Bienkopp is not the kind of Heimatroman that romanticizes country life nor does its author uncritically conform to the tenets of socialist realism. With Ole Bienkopp's story, Strittmatter reveals the problems of an agrarian politics that fails to orient itself on the specific needs of the country's farmers and that is paralyzed by its authoritarian structures and bureaucracy. With the protagonist's death at the end of the novel, Strittmatter dramatizes the misguidedness of party politics and exposes the system's inhumanity. An important aspect of the work's local color quality is Strittmatter's language in which he duplicates the cadence and idiom of the region's dialect. Similarly, the short, abrupt sentences of the dialogues, which consist mostly of an exchange of questions and answers, are typical of the spoken language of common folk. ${ }^{31}$ Johannes Bobrowski's best-known fictional work is his novel Levin's Mühle published in 1964. The novel is set in the former West Prussia of the early 1870s, during the cultural war between German nationalists (who considered themselves as racially and culturally superior) and the different ethnic minorities - mostly Poles, Jews, and gypsies - that inhabited the region. Its main themes are racial and religious doctrinism and discrimination, oppression, and the failure of justice. Characteristic for Bobrowski's style is a particular fondness for the offbeat, the odd, and the obscure. The tone and the precision of his descriptions speak of a keen eye for the typical as well as for the more

${ }^{31}$ A writer of Heimatliteratur who belongs to a later generation of GDR writers and should at least be mentioned here is Helga Schütz. Schütz began writing fiction in the early 1970s and set out to chronicle everyday life in the backward regions of the GDR's countryside, covering various periods of GDR history. A few of her titles are Vorgeschichten oder schöne Gegend Probstein (1970), Erdbeben bei Sangerhausen (1972) and Jette in Dresden (1977). The humor in her descriptions, the precision and terseness of her language, and their attention to detail is equal to Bobrowski's and Strittmatter's writing styles. 
subtle and seemingly unimportant aspects of daily life. Another way in which Bobrowski captures a sense of time and place is through language. Like Strittmatter, he intersperses his narrating with the colloquialisms and the jargon of the regional dialect. Though one might be tempted to consider the novel a piece of socialist realism, in reality Borbrowski undermines the Marxist notion of history as a transforming and progressive force. In Levin's Mühle, just as in Ole Bienkopp, human nature wins and justice does not prevail at the end.

Though not explicitly a work of local color or a piece of Heimatliteratur, Christa Wolf's novel Der geteilte Himmel (1963) needs to be included here. The two aspects that define the work's regionalism are the detailed descriptions of the lives of the country's industrial workers (the novel was inspired by Wolf's experience with the Bitterfelder Weg program) and the novel's historical setting — one of the most dramatic moments in Germany's post-WWII history, the country's division. Soon after its publication, Der geteilte Himmel was one of the most widely read pieces of GDR-literature in the West partly because of its topical nature and partly because of Wolf's detailed descriptions of everyday life in the East. (Literature was one of the few sources of information about the GDR for citizens in the Federal Republic.) The idea of dividedness runs like a red thread through the novel, and it is never completely resolved despite the novel's supposedly happy ending - Rita's decision to stay in the GDR to participate in the building of a truly socialist society. Though it may seem that the novel completely affirms the country's political system, Wolf uses a number of ways to undermine an all too positive interpretation of the novel so as to provide a more realistic picture of the country's political reality at the time. For example, Wolf greatly elaborates on the various reasons 
why Manfred decides to leave the country, and indeed his dissatisfaction with the system and his skepticism towards the government's dogmatism and bureaucracy are not completely unfounded. Similarly, her description of the factory workers' life - the harshness of their work environment and their continuous frustration with government policies and regulations - gives a rather disillusioning picture of the class that is supposed to bring about historical progress. Again and again, Wolf subtly modifies Rita's affirmative stance and invites the reader to question the workings of real existierendem Sozialismus.

\section{B. The Individual in the Midst of Historical Processes}

One favorite subject matter among writers from the former GDR is the effect of historical processes on people's lives. Though the citizens of both Germanys lived through the terror of National Socialism, the two countries had different ways of dealing with this dark part of their history. Proclaiming the country as anti-fascist rampart, the East German government expressed its opposition to the Nazi regime, but it never dealt directly with the question of how it was possible for Nazism to come into being. East German writers picked up on the party's refusal to address the problem of Nazism and Fascism, and since this topic was not to be addressed in public, it became the subject matter of numerous literary works. Moreover, Eastern Europe's turbulent history during the fifties and sixties and the government's repressive policies made East German writers particularly sensitive to the topic of history's impact on the life of common people. Thus, a recurring topic in GDR-literature, from the early years of the country's existence all through the 1980s, is the country's violent and oppressive past, whether this means the 
horror of Fascism, the trauma of people's expulsion from the regions furthest to the east, or the terrors of Stalinism. Describing people's suffering under cruel and unjust rule, pointing out past mistakes, and dealing with the question of guilt, are the dominant themes of this kind of literature. Though not an exclusively GDR topic, life during the Nazi regime was of particular interest to writers and intellectuals in the GDR, because many saw the Socialist Unity Party's repressive politics as a remnant of fascist thinking - not to mention that former Nazi officials had been accepted into the ranks of the country's party functionaries. Most of the narratives dealing with this subject matter depict issues such as people's passivity and conformism, their blindness towards the evils of the system, and their silent acquiescence to injustice.

One of the writers who specifically set out to write against forgetting the lessons taught by recent history was Jurek Becker. A Polish Jew who spent his childhood in ghettos and concentration camps, Becker had first-hand experience with the material of his fictions. Among his best-known works is his first fictional narrative, Jakob der Lïgner (1968). ${ }^{32}$ Most striking about the novel is the stark contrast between its playfulness in form and language and the seriousness of its subject matter. Becker describes everyday life in the ghetto of Lodz in great detail, but he does so without pathos, even when depicting the various horrors that the ghetto's inhabitants had to endure on a daily basis. Jakob's story is told retrospectively by a first-person narrator, one of the few survivors from Jakob's ghetto, and the year of the narrating is 1967. In an

\footnotetext{
${ }^{32}$ Another work in which Becker uses his personal experience during the country's national socialist past is his novel Bronsteins Kinder, published in 1987. This time, Becker intertwines a love story into the narrative about Nazi crimes and the Jewish people's suffering, and as before distancing is the essential component of his narrative technique.
} 
effort to better understand the reasons for and effects of Jakob's lie, the narrator tries to reconstruct from memory the final weeks of the Ghetto in late 1944. Most of the novel is relayed from Jakob's perspective, but with the narrator's repeated intrusions and the frequent, long passages of seemingly trivial detail, Becker eases the dramatic tension and creates a sense of distance to the deeply disturbing subject matter, to the cruelty and abuse. Another way Becker distracts the reader from the horror of what is being narrated is by foregrounding the narrative's constructedness. Repeatedly the narrator comments on the unreliability of his memory, and he admits that sometimes he is drawing on his imagination to make up for what he does not know or remember. This is especially true for the novel's ending, when the narrator refuses to subject his story to history's injustice and therefore decides to add a second, more positive ending to what really happened. Instead of having all the inhabitants of the ghetto transported to the death camp, he twists the plot so that only Jakob dies while all the other Jews are liberated. Through his careful manipulation of narrative form and language, Becker manages to show that, after all, there is a way in which even the unspeakable can be spoken about.

To return to the dark periods of (East) German history, Nazism and Fascism, is an often-used strategy. In doing do, GDR writers not only combat the dangers of forgetting but also point towards present problems and injustices. One of the more successful and widely praised works of this kind is Christa Wolf's novel Kindheitsmuster, which was published in 1976. Unlike Jakob der Lügner, which tells the story of those who fell victim to the horrors of Nazism, Wolf writes about those who through their ignorance, their passivity, and their silence unwittingly became participants in an inhuman system. Generally speaking, Kindheitsmuster is about the importance of confronting the past in 
order to understand who we are today. Remembering is a faculty that needs to be exercised, the narrator says at the beginning of the novel. If we don't make ourselves remember, that which is to be remembered will vanish and we may never fully understand who we are. ${ }^{33}$ More importantly, remembering past mistakes will help prevent us from repeating them in the future. For the novel's protagonist, this past is her childhood during the years of the Nazi regime and the many experiences from that time that for decades have been repressed, silenced, or simply forgotten. During her often painful and lonely journey into the past, the narrator returns to a childhood spent in a harsh, authoritarin environment that was meant to make her into an uncritical follower of the system. Self-censorship, conformism, the fear of not fitting in, and self-deception are the patterns she internalized and they are still affecting her behavior and decisionmaking, the narrator realizes.

One of the most interesting works about childhood memory and taking account of the past is Uwe Johnson's tetralogy Jahrestage. Aus dem Leben von Gesine Cresspahl (volume 1-3, 1970 - 1973 and volume 4, 1983). Gesine Cresspahl was born and raised in Meckelenburg but in 1961 left the GDR for New York City. Disillusioned about her life in the United States, Gesine wants to pass on to her daughter Marie her family history and depictions of the land where the child spent the first few years of her life. Thus Gesine begins to tell and also write down for Marie the story of her own childhood as well as that of her family. Each of the novel's four parts deals with a specific aspect of East German history from 1931 until 1953 - the Nazi regime, the post-war years, Stalinism, and life in a Russian prisoner's camp. Johnson describes in great detail

\footnotetext{
33 “Ein ungeübtes Gedächtnis geht verloren, ist nicht mehr vohanden, löst sich in nichts auf, ... (Kindheitsmuster, 15).
} 
people's everyday lives in the East German region of Mecklenburg and their suffering during the violent the years of Nazism and Stalinism. The part of the novel that takes place in the present spans exactly one year, August 21, 1967, to August 21, 1968, the day of the Soviet's invasion of Prague. Thus, just as in Kindheitsmuster, the narrating shifts back and forth between past and present, showing how the past is still part of the present. But Jahrestage is not just a fictional chronicle of GDR history. Gesine's recollections about her and her family's life in the East are counterbalanced by descriptions of her present life in the United States and numerous references to American imperialist politics. While this fact could speak against calling the work a piece of GDR-literature, Jahrestage is actually an excellent example of the category's intrinsic inclusivity. Once again, I want to refer to Wolfgang Emmerich and his notion of GDR-literature. Emmerich goes so far as to call Johnson's tetralogy a Heimatroman because the novel is characterized by subterranean connections ("unterirdischen Verbindungen") to the land where its author was born and where he grew up. Jahrestage, Emmerich argues, is a novel about Heimat in the sense that it deals with the topic of being uprooted and is written by someone who has no home (ein Heimatloser) $(325) \cdot{ }^{34}$ The intrinsic ambiguity and dividedness of Jahrestage - this mixture of GDR Heimatroman and American diary - poignantly exemplifies what I referred to earlier as the need for keeping the category GDR-literature open and for regarding the term's fluidity as one of its fundamental characteristics. Johnson's work demonstrates that Emmerich's request, “den

\footnotetext{
${ }^{34}$ Aside from the fact that Johnson captures in great detail what life was like during the different historical periods of Gesine's life in the former GDR, the theme of dividedness as represented by Gesine's living between two worlds - her home, the GDR, she can never return to, and the United States, the place that is not yet her home-is especially relevant to a literary text written about the GDR by an author who spent the formative years of his life in the former GDR.
} 
Begriff DDR-Literatur nicht künstlich eindeutig [zu] machen, sondern beharrlich offen [zu] halten," is a necessity if only because literature is a complex system whose parts are intricately interwoven and affect each other in different ways and on different levels (Kleine Literaturgeschichte, 21). ${ }^{35}$

The artificiality of labels is always something to keep in mind when categorizing any group of literary works, but it is especially important when it comes to describing GDR-literature. The different themes I listed as characteristic for this literature do not appear independently of each other, nor are they exclusively GDR themes. At the same time, however, writers from the former GDR seem to be particularly sensitive to such issues as the oppression of others, intolerance towards those who are different, and disregard for human rights.

\section{Exploration of the Self and the Concept of Subjective Authenticity}

Beginning with the late 1960s, in response to the tightening of the government's control over people's personal lives, writers in the former GDR became especially interested in questions of individual rights and personal freedom. Though during the 1970s, questions of selfhood, personal freedom, and self-fulfillment were topical themes in the Federal Republic, in the former GDR, these issues were of existential importance and had an urgency that was unparalleled in the West. Especially after the Soviet Union's invasion of Prague, in August 1968, many writers who had clung to their utopian vision of a more democratic socialism were forced to realize how the kind of socialism they had

${ }^{35}$ This notion of inclusivity plays an important role in the discussion of contemporary East German literature and the question to what extend some of the post-Wende works by East German writers could be considered GDR-literature. 325) 
envisioned in no way matched the one practiced by the government. The increasing disillusionment with the real existierenden Sozialismus led writers to a more subjective narrating and to exploring the inner lives of their characters. This turn inward was accompanied by a shift towards a more unconventional form of narrating as writers had to find ways of giving form to the complexity of mental processes. Finally, this shift in focus was accompanied by an increased skepticism towards language as a means of communication and by a heightened sense of language's fallibility and intrinsic ambiguity.

A writer whose oeuvre best reflects this shift in perspective-the movement from the communal "we" to the personal "I"-is Christa Wolf. While Rita, the protagonist in Der geteilte Himmel, finds personal fulfillment and happiness in her commitment to the advancement of the socialist state, the protagonist in Wolf's next novel, Nachdenken über Christa T., no longer shares Rita's idealism. Christa T. sees the system for what it isrepressive, authoritarian, and unjust - and she is haunted by the clash between her own humanitarian views and what she sees realized by the system. But Nachdenken über Christa $T$. is also a seminal work in the history of GDR-literature because it prepared the way for an aesthetically more imaginative and innovative kind of writing. Wolf creates a protagonist who is neither a positive role model nor a hero as defined by socialist realism; insisting on her right to be different and to be herself, Christa T. refuses to comply with the demands of the system. But also formally the novel prepares the way for a more complex and unconventional kind of narrating. Throughout the novel, Wolf engages in an intricate play with distance and closeness, which characterizes the narrator's relationship to her childhood friend Christa T., the novel's protagonist, and which is most 
dramatically reflected in Wolf's creative manipulation of narrative perspective. Wolf has Christa's story be narrated retrospectively, after Christa's death, by a first person narrator who was Christa's friend and for whom thinking about and telling of Christa's life - the "nach-denken" (thinking afterwards) about Christa - also affects her personally as it leads her to a "nachdenken" (a reflecting) about her own life and her own actions (9). The result is an intricate interplay of voices with a constant shifting in perspective between an "ich" (the narrator) a "sie" (Christa T.) and a "wir" (the two together). The narrating itself is non-linear and switches back and forth between remembering (past-tense narration), anticipating (short passages related in the future tense), as well as reflections and recording of dreams (present tense narration). To give her re-creation of Christa's life a sense of authenticity and objectivity, the narrator uses Christa's letters and her diaries to back up her story. At the same time, however, she knows that memory is by nature unreliable and incomplete so that often she has to use her imagination to fill the many gaps in Christa's story. Often the two voices, that of the "I" and Christa's, become indistinguishable from each other so that the narrating "I" wonders whether she has been recording Christa's ideas or her own.

In Kindheitsmuster, Wolf further developed and perfected her method of subjective narrating. In this novel, the narrating "I" is searching for her own troubled self rather than trying to understand the being of another person. The narrator's self, however, is in conflict with itself and is split into three different personae - an "ich," a "du," and a "sie." There is first of all the "sie," Nelly, who is the narrator's childhood version of herself. Referring to this earlier version of herself as "she" not only shows the distance the narrator feels towards her earlier self, but it also signifies her need to protect herself 
from this past. Secondly, even when the narrator talks about her present self, she uses the distant "du" instead of the "ich," which indicates she feels alienated even from her present self and is unsure as to who this "ich" really is. ${ }^{36}$ Only at the very end of the narrative will the narrator allow herself to use the pronoun "ich." But rather than conveying affirmation, the context in which she uses the word ("Ich weiß es nicht") indicates that this "ich" is still not certain about herself (378). She realizes that only the future can tell whether her journey into the past has helped break the destructive forces of memory and will give her inner peace.

Directly related to this complex play with narrative perspective and voices is the novel's division into three separate but intricately interwoven strands of plot. There are first of all the narrator's childhood memories, which span the years 1932 to 1947. Then there is the story about the narrator's weekend trip to Poland to visit the town where she was born and grew up. This visit happened on July 10 and 11, 1971, and it is this event that prompted the narrator's journey into her past. The report about this trip is told in the present tense. The third plot, also written in the present tense, deals with the narrator's insecurities and difficulties while writing down her memories; its storyline continues over several years. Aside from being a kind of writing journal, this part of the novel also focuses on current political events as well as incidents from the narrator's personal life. This kind of interlacing of past and present combined with Wolf's creative play with

\footnotetext{
${ }^{36}$ Right at the beginning of the novel, the narrator tries to explain this difficulty to say "I"- her Sprachstörung - as follows, "Zwischen dem Selbstgespräch und der Anrede findet eine bestürzende Lautverschiebung statt, eine fatale Veränderung der grammatischen Bezüge. Ich, du, sie, in Gedanken ineinanderschwimmend, sollen im ausgesprochenen Satz einander entfremdet werden" (9). Also, occasionally, the narrator speaks of a "wir" and thereby draws the reader directly into her reflections. Usually, this "wir" appears when she reflects upon questions of existential and general human importance.
} 
narrative tense is the formal representation of the novel's main theme, "Das Vergangene ist nicht tot; es ist nicht einmal vergangen" (9). ${ }^{37}$

These fictional narratives by Christa Wolf represent a way of narrating that was new at that time, in which Wolf combined the autobiographical with the fictional, a method that later came to be known as subjective authenticity (subjektive Authentizität). It is a kind of narrating in which the boundary between the author's subjective experience and insights, objective historical processes, and invention is broken down with the purpose of having the reader become actively involved in the process. In her essay, "Lesen und Schreiben," Wolf explains that in addition to the three fictional coordinates of the invented characters' world, every narrative should have a fourth dimension, that of the narrator's "reality” (“die . . . ‘wirkliche' des Erzählers”). She calls it the coordinate of depth, of contemporaneity, of unavoidable engagement_- "die Koordinate der Tiefe, der Zeitgenossenschaft, des unvermeidlichen Engagements" (Dimensionen des Autors, 487). In this essay, Wolf repeatedly emphasizes the writer's responsibility to tell the truth and compares her narrative method to that of Brecht's epic theater. Like Brecht, she believes that the purpose of literature should be to help readers arrive at a clearer understanding of themselves and of life's complexities (490).

A work from the later years of the GDR's existence that also deals with the topic of self-hood and individual freedom is Monika Maron's Die Überläuferin, which was published in 1986, but only in the West. Die Überläuferin tells about a woman who wakes up one morning and finds herself paralyzed. The resemblance to Kafka's Gregor

${ }^{37}$ The narrative tense in which a particular event is told is not always defined by rules of grammar or logic. Thus, whether an event is told in the present, the past, or even in the future tense directly reflects the narrator's emotional closeness or distance to this event. 
Samsa is not coincidental, as Rosalind's paralysis, too, represents a silent rebellion against her life - a life characterized by self-denial, repression, and conformism. Immobile and in the isolation of her room, Rosalind withdraws into the world of her imagination and fills her days by conjuring up real and invented events from her previous and present life. As she allows her mind to wander freely even to the most feared and most deeply repressed aspects of her being, she is able to shake off her false self, leave behind the life imposed upon her by social conventions, and become truly free. Maron's unconventional writing style complements the surrealism of Rosalind's story as the imagined and the factual become indistinguishable. The narrating switches seamlessly from one to the other so that fantasy and reality become merged into one; there is no unified narrative perspective as the telling changes at random between a third-person detached, omniscient narrator and first-person narration. Structurally, too, the text defies narrative conventions. It is a conglomeration of different texts that seamlessly blend into one another. First there is the omniscient narrator's detached reporting, which is, however, counterbalanced by numerous daydreams and fantasies conjured up by the first person narrator's imagination. Then there are Rosalind's memories, her imagined dialogues with people she knows, and several invented dramatic scenes (Zwischenspiele), in which Rosalind exposes and simultaneously ridicules the intolerance and narrowmindedness of GDR society. Both with respect to its form and its subject matter, the novel is an outcry against conformism. 


\section{The East German Entwicklungsroman}

Self-discovery and the search for one's personhood are topics that are central to a particular type of narrative, the Bildungsroman (novel of education), a genre that was particularly popular among writers in the former GDR. ${ }^{38}$ Traditionally, the novel of education is a fictional narrative about a young person's self-formation and selfdevelopment. It describes the process of his (the protagonist was usually male) psychological, intellectual, and moral growth and shows his gradual transformation from a self-centered, unformed youth into a responsible and exemplary citizen who is dedicated to the welfare of society. Generally, Goethe's Wilhelm Meisters Lehrjahre is considered the prototype of this kind of fictional narrative. The Hungarian Marxist and critic Georg Lukács, who heavily influenced the development of socialist realism in the former GDR, considered the basic concept of Goethe's novel as especially well suited for socialist realist fictional narratives. Its plot lent itself to the teaching of socialist values through characters who, having internalized the party's doctrine and being dedicated to the socialist cause, provided a positive role model for the common citizen. Favoring Lucács' theory over that of other Marxist critics, party functionaries in the GDR soon encouraged its writers to use the novel of education as blue print for their fictional narratives.

Of the works I mentioned so far, Christa Wolf's Der geteilte Himmel comes closest to Lukács's notion of the Entwicklungsroman. As already mentioned, the novel describes Rita's transformation into becoming a confirmed socialist. The only difference

${ }^{38}$ In the former GDR, instead of Bildungsroman, the more commonly used names were Erziehungsroman (novel of upbringing) or Entwicklungsroman (novel of development). 
is that Wolf's protagonist is a woman, which means that the novel deals with issues specifically related to women's lives in the East Germany of the early 1960s. When in the late 1960s and early 1970 s the State's restrictions on literary production were temporarily loosened, writers who disagreed with current party politics began adopting the pattern of the Entwicklungsroman to criticize real existierenden Sozialismus and its repressive politics. They developed a new kind of Entwicklungs-/Bildungsroman, which now focuses on questions of individual freedom and personal fulfillment rather than the conforming to pre-established social norms. Also, unlike in the traditional novel of education, the conflict of individual versus society usually remains unresolved as the individual realizes that the system does not allow for compromises.

This other version of the Entwicklungsroman was first introduced by Christa Wolf in her novel Nachdenken über Christa T. Though like Rita, the protagonist in Der geteilte Himmel, Christa T. believes in the socialist cause, Christa T. quickly realizes that the gap between her ideals and the system as it actually is cannot be bridged. But quietly succumbing and conforming to what is an offense to a person's basic human rights is not an option for Christa. She keeps insisting on her right to personal freedom while her idealism prevents her from giving up her fight for social improvement. When at the end of the novel Christa dies of leukemia, there is a question as to the true cause for her death. The reader cannot help but wonder whether Christa's death was not her way of rebelling against a system that thwarts people's right for freedom and self-fulfillment. Indeed, as Lorna Martens has pointed out, Christa T. is one of the first fictional works published in the former GDR which insists "that 'fulfillment' is a personal, private, 
subjective affair, which is not to be had by leading one's life according to a prescribed pattern" (The Promised Land?137/38). ${ }^{39}$

In Monika Maron's Die Überläuferin, the protagonist experiences a conflict with social norms and a restriction of personal freedoms similar to Christa T.'s, and here, too, the conflict remains unresolved. Like Christa T., Rosalind realizes that by conforming to society's norms means sacrificing her selfhood, but unlike Christa T., who escapes into illness and finally death, Rosalind chooses to withdraw into the world of imagination. To a certain extent, Wolf's Kindheitsmuster is also modeled after the Entwicklungsroman, though the novel is less about the clash between individual and society than it is about the protagonist's conflicts between the different aspects of her inner self (as dramatized by the splitting of voices), but as in the case of Christa $\mathrm{T}$. and Rosalind, it is a self that was shaped by a repressive environment. Going back to the childhood fears and trauma buried inside her, the narrator tries to come to a new self-understanding. But unlike the two other works, both of which are stories about rebelling, Kindheitsmuster is first of all a novel of healing and of coming to terms with one's past.

It is no coincidence that the narratives mentioned so far as examples of the Entwicklungs-/Bildungsroman are written by women and have women as their protagonists. This kind of female novel of education was a form of narrative much preferred by women writers in the former GDR, where because of the different social structures, women were confronted with issues distinctly different from those that preoccupied Western feminists. On the one hand, women in the GDR were more

${ }^{39}$ More information about Christa T. as a type of female Bildungsroman and about other representatives of this subgenre can be found in Lorna Martens, The Promised Land? Feminist Writing in the German Democratic Republic (Albany: State University of New York Press, 2001). 
emancipated than women in the West in the sense that they had an equal right to education, they were an important part of the country's work force, were provided with free child care, and received various other benefits that helped them manage the demands of work and family. On the other hand, however, their privileges were overshadowed by the pressures to conform and by severe restrictions of personal freedoms, as even people's personal lives were subjected to government control. (For example, women may have had the same right to higher education as men, but ultimately, it was up to the government and not the individual to decide on the kind of education and the profession a person was allowed to pursue.) ${ }^{40}$ This tension between freedom and confinement became an important topic among the East German women writers in the seventies. Another distinctive quality of the female novel of education is that their protagonists are most often women in midlife. They are women who, like Christa T. and Rosalind, spent years trying to conform to society's expectations and to live within the parameters dictated by the system, but who finally come to realize that they are in danger of losing sight of themselves.

The question of female identity in contemporary society is of course not a concern of East German writers only, but as Ricarda Schmidt has pointed out in her comparative study, "The Concept of Identity in Recent East and West German Women's Writing," there is a decisive difference in the way in which women writers in these two countries went about exploring this subject matter. According to Schmidt, and as shown in the previous discussion of the texts by Wolf and Maron, the most decisive difference is that

${ }^{40}$ Needless to say, since higher education was paid for by the government, one of the ways the government punished those who voiced criticism or failed to conform was by barring them from receiving any kind of advanced education. 
East German writers "set the question of identity primarily against the background of direct political oppression" (442). Also, as pointed out by Schmidt, both East German writers "develop concrete, positive counterideals of identity" (443). They offer solutions that are situated outside of society, however, and are located within the individual female subject herself. Though they do so in different ways, both writers suggest that the individual can indeed take control of her life and "develop positivized concepts of identity against the background of political oppression" (437). Aside from lacking their eastern colleagues' historical perspective, the two West German writers also do not share Wolf's and Maron's utopian outlook. They focus first of all on exposing "the complexities and problems of female subjectivity," and though the need of radical change is certainly implied in their protagonists' strivings, these writers do not suggest possible venues for true change (442).

One novel that stands out among the GDR novel of education is Ulrich Plenzdorf's Die Neuen Leiden des jungen W. (1972). Though Plenzdorf's Edgar Wibeau is more like the protagonist of the typical Entwicklungsroman-a young man, on the verge of adulthood, who is trying to find his way into society - Plenzdorf, like Wolf and Maron, did not follow the prescribed pattern of the GDR novel of education. Instead, he transformed the story of Edgar's (failed) education into a humorous parody of the Lukácsian Entwicklungsroman. Edgar Wibeau repeatedly finds himself in conflict with his environment - at home, in school, and at work - because instead of blindly following rules and subjecting himself to the authority of his superiors, Edgar is critical, thinks for himself, and resents conformism. Unlike the adults who, disillusioned by experience quietly conform and unquestioningly comply, Edgar, still ignorant of the workings of a 
repressive system, openly questions the status quo and speaks his mind. He is quickly branded as a rebel though he is always concerned with the wellbeing of those around him. Edgar runs away from home and hides in a small cottage in order to think about what his next step in life should be, but from the beginning, he sees his isolation as temporary. Yet before Edgar can arrive at any important conclusion about his future, he dies as the result of a careless mistake. It is in the novel's ending where Plenzdorf most blatantly undermines the idea of the Entwicklungsroman. When Edgar, having returned from the dead, looks back over his experiences during the last few weeks of his life, he is still not able to understand the true cause of his problems. Too inexperienced and also too trusting, Edgar fails to see how he was the victim of a fundamentally repressive system. Unlike Christa T. and Rosalind, Edgar is still too young to know that he has a right to be critical and to be his own person. He does not understand that his desire always to be the "Sieger" is nothing but his way of expressing his need to be himself. Strictly speaking, then, Die neuen Leiden des jungen $W$. is not about the education of the novel's protagonist, Edgar, but it is about educating the reader. Only the reader is able to see that Edgar has the right to be different, and only the reader understands that the true reason for Edgar's conflicts was not so much his youthful impudence and arrogance but a system that would not allow its people to be different.

One other important aspect of Plenzdorf's novel is its unconventional form and Plenzdorf's creative manipulation of narrative perspective. The story begins after Edgar's death and is narrated retrospectively by different narrators. The novel's unusual structure is a direct result of Plenzdorf's eccentric approach to his material, an approach that involves a mixing of viewpoints and consists of an intricate interplay between distance 
and closeness. After finding out about of his son's death, Edgar's father, who had been absent from his son's life since the boy's childhood, wants find out more about his son and the circumstances surrounding his death. He thus sets out to interview a number of people who were in close contact with Edgar during the last few weeks of his lifeEdgar's mother, his closest friend Willi, a young woman named Charlie, with whom Edgar had fallen in love, and Edgar's most recent boss, Addi. In the novel, these conversations are presented directly as dialogues. Edgar eavesdrops from the afterworld on what is being said about him and then comments on, explains, and further elaborates on what he hears. Aside from choosing several narrators and thereby describing Edgar's character from different perspectives, the true ingenuity of the narrative's point of view is having Edgar speak from the grave. Now that his life is over, Edgar has nothing to lose and nobody to impress. Being simultaneously the subject and object of his story, Edgar is more like an omniscient narrator than a first-person narrator, which is a rather ingenious play with narrative perspective. Finally, much of the novel's unique effect is due to Plenzdorf's ironic humor, which is the result of the clash in knowledge between Edgar and the reader that I described earlier.

\section{E. Irony-Telling What Mustn't be Told}

One aspect of GDR-literature that is of primary importance for literature written in the GDR is the many ways in which the country's writers use irony both as a rhetorical device and as a mood in the sense of an implied attitude towards their subject matter. East German writers' special sensitivity towards language is directly related to the country's political climate. For example, especially during phases of strong censorship, critical and 
dissenting writers were forced to speak their mind indirectly and mask their true meaning. In addition, the government's abuse of language as an instrument for deception - as a means for twisting the truth and manipulating people into believing something that did not really exist-deepened writers' awareness of the fallibility of language. Therefore, writers in the former GDR were more attuned to matters of language than writers in the Federal Republic. Unlike their Western colleagues, who were able to voice their criticism freely, East German writers had to think of 'hidden' ways with which to increase their readers' awareness of existing incongruities between socialist ideology and everyday reality. Some of the more frequently used techniques writers employed to 'tell the truth' were doublespeak, witty word play, and verbal and dramatic irony. But especially beginning in the late 1960s and during the 70s, writers such as Christa Wolf, Irmtraud Morgner, and Ulrich Plenzdorf began to write texts in which irony was more than intelligent word play and came to represent a way of thinking about the world and about writing. These writers reveal the ironic mood of a text through self-reflexivity, through a self-conscious foregrounding of its artificiality, and by acknowledging the subjective nature of reality.

One of the more entertaining pieces of GDR-literature in which the author makes extensive use of the different forms of irony is Plenzdorf's Die neuen Leiden des jungen $W$. Much of the work's charm and humor is a result of the clash between Eddie's teen jargon and the kind of language one would normally expect in a literary text. The text's major source of irony and humor, however, stems from Eddie's naïveté, i.e., the fact that he is still totally unaware of the different ways in which he is being manipulated and indoctrinated by the party's spokespersons. He knows that he must respect authority and 
do what is asked from him, but finds himself repeatedly caught in the conflict between doing what he is told while at the same time seeing the absurdity of what he is asked to do. He tells things as they are and refreshingly speaks his mind without realizing that these things should better not be spoken of. One such example is Edgar's comment about the movies (the "Pflichtfilme") he had to watch as part of his school's history curriculum. Oblivious of the fact that these films are meant to indoctrinate the students and falsely praise the benefits of real existierendem Sozialismus, Edgar finds them a very practical and timesaving solution to reading long and boring historical texts. If one must endure boredom, the less time one spends being bored the better, Edgar concludes innocently. Edgar freely speaks his mind without knowing that he is telling a truth that the reader knows must not be told. Indeed, much of the novel's irony is related to Plenzdorf's choice of perspective, in the way he is casting Edgar as an unfinished (in the sense of not yet fully adjusted) youth who has not yet learned to appreciate the blessings of real socialism. Exactly because Edgar is not a rebel but simply a confused young man, his criticism is softened but certainly not less true..$^{41}$

Die Neue Leiden was written during the more liberal phase of government censorship, which allowed Plenzdorf to be more outspoken in his criticism and use a more overt kind of ironic humor. Usually writers from the GDR resort to a less apparent kind of irony and also one that is less light-hearted. This kind of 'hidden' irony is highly effective as its subtlety only accentuates the nature of the problem that is being covered

\footnotetext{
${ }^{41}$ That Plenzdorf could be so outspoken with his criticism of the system is not just because of Edgar's youth and inexperience, but it is also directly related to the GDR's cultural politics at the time when the novel was written. During the early seventies, there was a phase when the socialist Unity Party loosened its restrictions and granted writers more freedom in their choice of subject matter and in expressing their criticism than ever before.
} 
up. One of the best examples of this kind of irony can be found in Christa Wolf's narrative Der geteilte Himmel. In my earlier discussion of the novel, I mentioned that in general Rita's story seems affirmative of GDR socialism, but then there are numerous occasions when Wolf destabilizes the "happy" ending, thus alerting the reader to the still existing inconsistencies and antagonisms within real existierendem Sozialismus. Manfred, Rita's fiancé, for example, plays the role of antagonist as he voices the concerns and frustrations of those who do not share Rita's belief in the future of Socialism. One of the less obvious ways in which Wolf points towards this gap between real and ideal is through the work's structure. Rather than starting in medias res, Wolf frames Rita's story with a brief introductory and concluding section in which she puts Rita's personal story in the larger context of the townspeople's life in order to emphasize the exemplary nature of Rita's story. Already in the introductory part of the frame, the attentive reader will discover a strange incongruity between the depressing and gloomy description of the town and its people and the calm and detached language with which the narrator renders this description. Indeed, it seems as if the narrator were totally unaware of the intrinsically desolate state of the people in this town. Similarly disturbing is the indifference with which these people (and the narrator is obviously one of them) succumb to a life of tedious routine; how they fill their days with various mundane tasks; and successfully suppressing their unhappiness, they manage to sleep calmly at night. But then, in the section's concluding statement, as if unaware of what she previously described, the narrator assures us that she and the townspeople live life to the fullest as if it could never get used up..$^{42}$ But who would want to live such a life?

\footnotetext{
${ }^{42}$ Wolf writes, "Wir leben aus dem vollen, als gäbe es übergenug von diesem
} 
In the concluding segment frame, after Rita's story has reached its happy ending, the narrator repeatedly assures the reader that Rita will be fine (but why repeat twice that she won't be afraid?) and will be leading a full life. Then, as if to confirm one last time that a happy future is waiting for Rita, the narrator concludes her narrative by almost literally quoting the last few lines of the introductory frame. What seems an elegant rhetorical move turns out to be fatal as far as the novel's ultimate meaning is concerned since this return to the beginning structurally as well as semantically undermines the seemingly positive ending. Semantically, the repetition evokes the oppressive tone of the initial frame and the scene's negative connotations. In this context, the implication that Rita is now one of the townspeople makes her future look decidedly less hopeful than suggested by the earlier part of the concluding frame. Will Rita end up like the people described in the novel's beginning - trapped in the dull routine of a drab existence? The circular structure suggested by the repetition further supports the negative interpretation of the novel's ending as it suggests Rita's entrapment in a monotonous life that will forever bar her from real happiness. With this narrative sleight of hand, Wolf slyly destabilizes the novel's affirmative ending and albeit subtly, questions Rita's idealism.

Of those writers from the former GDR who use irony as more than a rhetorical device, one who deserves special mention is Irmtraud Morgner. As one of the country's most creative and innovative authors and a key figure in the history of storytelling in the GDR, Morgner takes the ironic mode to a new level of sophistication by making irony the work's central narrative strategy. The text in question is her novel Leben und Abenteuer der Trobadora Beatriz nach Zeugnissen ihrer Spielfrau Laura, which was published in

seltsamen Stoff Leben, als könnte er nie zu Ende gehen” (7). 
the GDR in 1974, one year after Plenzdorf's Neue Leiden. Pages could be filled with examples of irony in Morgner's narrating, but for the sake of brevity, I will focus on just a few aspects of Morgner's use of irony - the text's self-conscious fictionality and Morgner's ironic play with authorship and voices. One way to describe the novel is in terms of an intricately orchestrated collection of different texts, different voices, and different viewpoints. Indeed, one of the more original aspects of Morgner's technique is how she weaves together a large variety of texts, ranging from the fantastical and the clearly fictional to the purely objective and factual. Though the novel addresses numerous contemporary social and political issues - the most important of which is the question of women's rights-Morgner masks the work's topical nature by transforming it into a modern fairy tale. The fictional world of Trobadora Beatriz is populated by figures from Greek mythology, northern European legends, and medieval literature; one of its main characters, Beatriz de Dia, is a former provençal minstrel who, like Sleeping Beauty, is awakened after centuries of sleep in the year of 1968. Anything is possible in the world of Trobadora Beatriz. Repeated spontaneous sex changes, transcontinental flights on the back of a water spirit, and people taking on the identity of others, as in the case of Laura, Beatriz's side-kick, are some of the more spectacular of these otherworldy occurrences. Such flaunting of the novel's fictionality allows Morgner to address controversial topics and voice criticism without directly being held responsible and having the work censored.

Then there is Morgner's play with the topic of novel's authorship, directly related to which is her recycling different texts and her interweaving different voices. Morgner enjoys confronting her reader with different views and opinions, especially in the case of 
controversial topics, so that it often becomes impossible to deduce a specific message or opinion. For example, in the novel's introductory chapter, "Vorsätze," Morgner invents a complicated story concerning the question of the novel's authorship. The text, i.e., Beatriz's travel journal, was literally forced upon Morgner, the fictional author, by a stranger, a woman called Laura who later turns out to be Beatriz's best friend and companion. Aside from Morgner's tongue-in-cheek disavowal of her own authorship, later in the novel, it also becomes questionable whether Beatriz ever wrote such a journal. In the novel's last chapter, it appears that it was actually Benno, Laura's husband, who thought up the Trobadora's story in order to console Laura who was mourning the loss of none other than the Trobadora. Was it then perhaps Laura herself who wrote the story down, and was a man the true author of the story? Furthermore, the book includes a thicket of subplots and other stories from different sources whose purpose and meaning is not always apparent. The most developed of these tangent plots are the seven intermezzi, which are seven installments of a novel with the title Rumba auf einen Herbst. The reader is told that this novel was originally written by a writer called Irmtraud Morgner but then copied (i.e., plagiarized) by Melusine into her Melusinisches Buch. (How Melusine got access to the book is never explained.) Aside from playing with the idea of a bookwithin-a-book, by transposing a real life occurrence into the world of fantasy (the real Irmtraud Morgner did indeed write a book with the same title, but it was censored and did not get published till after her death), Morgner finds a way of making the "forbidden" text public. ${ }^{43}$ In fact, Trobadora Beatriz is filled with a virtual kaleidoscope of texts,

${ }^{43}$ There are several levels of irony at work here: First of all, the book-within-a-book idea is a technique frequently used in romantic literature. It represents the concept of the infinite becoming of poetry but at the same time transmits the idea of poetry as a closed 
among them fictional interviews between Morgner and Laura, letters and laudations, an imagined interview with the German news magazine Der Spiegel, a monograph on animate matter, an excerpt from an East German sex manual, and Volker Braun's "Song of Communism." An important aspect of Morgner's ironic method is that she often relishes in providing all kinds of opinions on a large number of controversial topics without providing definite clues as to where she herself stands on these issues. Indeed, these different texts comment on each other sometimes undercut or reinforce each other while simultaneously resisting being reduced to one specific idea, which is reminiscent of romantic irony, whose defining characteristics are its irreducibility and its undermining of the laws of reason. When after 657 pages of what is best described as a wild, highly entertaining, but at times also confusing and even vexing ride, the reader reaches the novel's last line, Morgner pulls her last trick out of her sleeve. By having the novel's last sentence revert back to its very beginning, Morgner emphasizes one last time that the world of Trobadora Beatriz is an invented and imagined world-not a real one. It is one of life's ironies that those who tell the truth are either ignored or, as was the case in the former GDR, are silenced. So what if the truth is presented as lie?

system, of the separation between the world of the imagination (art) and reality. Second, Morgner now reverses the relationship between the real and the fantastic. The tradition is to have imagined events presented as if they were real (this is how fairy tales work), but Morgner takes a real life event (the existence of her book) and transposes it into the world of the imagination. Thirdly, once again we have a witty play with authorship. In the fictional world, Morgner is ignorant of the fact that her forbidden is actually being copied and thus made public. Therefore, it cannot be she but Melusine, who copied the book, who is responsible for making public the (censored) material contained in the novel. 


\section{F. The Breaking Open of Narrative Form}

The notion that in the former GDR censorship and the government's tight control over the country's literary scene resulted in a literature of inferior aesthetic quality has long been proven a myth. While identifying and discussing the specific attributes of GDR-literature, I have already described some of the ways in which writers in the GDR engaged in aesthetically creative and sophisticated experimentation with literary form. Writers such as Uwe Johnson, Christa Wolf, Monika Maron, Ulrich Plenzdorf, and Irmtraud Morgner received international recognition for their innovative writing styles. I have already mentioned the different ways in which Wolf manipulates narrative perspective in Nachdenken über Christa T. and in Kindheitsmuster as a way of giving form to her narrators' sense of inner dividedness. Her most important contribution to the country's literary scene is a kind of narrating which constitutes an authentic representation of the author's experience. I mentioned Plenzdorf's combining of dramatic and narrative elements in Die neuen Leiden des jungen $W$. and how the novel's narrative situation breaks with the laws of realism. Similarly, in Die Überläuferin, Monika Maron undermines the conventions of realistic narration and uses post-modern narrative techniques to break down the border between reality and imagination as the world conjured up in the narrator's imagination is merged seamlessly with the description of everyday reality. Lastly, I pointed out how by employing irony also as a narrative method Irmtraud Morgner invented a new kind of storytelling in the GDR. I am not claiming that experimentation with narrative form is an exclusively GDR phenomenon, especially since during the last decade of the country's existence the two German literatures kept growing closer together. On the other hand, as has been pointed out by critics and 
historians familiar with the GDR's literary scene, the political situation in the former GDR inspired the country's writers to be creative and think of new and different ways of reaching their audience.

\section{Conclusion}

What differentiates GDR-literature from literature written in the pre-Wende West is first of all its regional quality. As East Germany became a satellite of the USSR after the end of the Second World War, life in the East began to develop along different lines from that in the West as a result of which writers in the East occupied themselves with different themes and focused on different topics than those in the West, and the literary phenomenon GDR-literature gradually emerged. In the previous pages, I identified some of the distinctive characteristics of this literature. I also mentioned how East German writers often chose as their subject matter the life of the country's working class and people living in the provinces and they showed how these people's lives were affected by historical developments, whether it was Nazism, Stalinism, or real existierender Sozialismus. Favored topics were the relationship between individual and state, an individual's responsibility to and role in society, and the question of individual freedom. In the late 1960s, a literature emerged that focused on issues of self-finding, selffulfillment, and personal freedom, in the context of which the phenomenon of the GDR Bildungsroman and in particular the female novel of education emerged. I also mentioned East German writers' specific sensitivity to language, especially their use of irony, both of which are rhetorical tools that were indispensable in a country where public discourse was strictly regulated and censored. Finally, contrary to popular belief-a belief that 
since reunification has been corrected - throughout the years of the country's existence, there have always been writers who published original and aesthetically demanding texts. Formal experimentation and play with literary conventions have been an integral part of the GDR's literary scene as shown in the works by such writers as Christa Wolf, Ulrich Plenzdorf, Uwe Johnson and Irmtraud Morgner.

In the following two chapters, I will show that writers who began their publishing career in the GDR did not all of a sudden change the way they wrote and that the new historical situation including the post-Wende socio-economic changes inspired a new wave of regional literature. I will do so by discussing selected works by Kerstin Hensel and Angela Krauß. I will begin with a discussion of Kerstin Hensel's novel Gipshut, which is one of the more remarkable examples of the continuation of GDR-writing styles and themes. Then I will turn to two narrative texts by Angela Krauß, whose writing style is reminiscent of Christa Wolf's aesthetics of subjective authenticity and whose subject matter is life in the post-Wende East. 


\section{Chapter Two. Kerstin Hensel's Gipshut: Weiterschreiben and the}

\section{Aesthetics of Disorder}

"[E]in in der Historie angesiedeltes Geschehen [ist] zwanglsläufig kein historisches, sondern ein gegenwärtiges."

(Kerstin Hensel in Néy, 6) ${ }^{44}$

"'Wird der Ernst zu groß, daß die Schmerztränen versiegen, ist höchste Zeit, Tränen zu lachen.'" (Kerstin Hensel, "TROBADORA PASSÉ. Irmtraud Morgner lesen I," 102) ${ }^{45}$

\section{Introduction}

If one were to name one East German writer from the post-Wende era whose works best embody a continuation of the GDR-way of writing whether with respect to regional character, choice of subject matter, or writing style, it would most likely be Kerstin Hensel. Her style of Weiterschreiben is a sophisticated and very creative kind of continuation, characterized by an ironic play with particular aspects of GDR traditions. When it comes to writing fictional texts, Hensel's preferred (indeed only) subject matter is the GDR and the post-Wende East, beginning with pre-GDR history and reaching up to the present. As she once mentioned in an interview with Birgit Dahlke, this is the life she knows best, and thus it only seems natural to her to use it as the material for her fictions

\footnotetext{
${ }^{44}$ Karin Néy and Kerstin Hensel, „Letztlich will ich nichts, als Aufklärer sein.” Ein Gespräch, Temperamente. Blätter für junge Literatur 3 (1989): 3-12.

${ }^{45}$ Kerstin Hensel, “TROBADORA PASSÉ (Irmtraud Morgner lesen I)” Angestaut. Aus meinem Sudelbuch (Halle: Mitteldeutscher Verlag, 1993) 100-102.
} 
(43). Another characteristic feature of her writing is her penchant for producing unconventional and provocative texts that are intellectually demanding and full of ironic humor. Indeed her fictions are a unique mixture of comedy and drama. They are deeply moving and often disturbing, challenging to read but also entertaining. Her characters are usually ordinary people, who though often grotesquely flawed and loathsome, still manage to elicit the reader's compassion. One of the most noteworthy qualities of Hensel's work is her sensitivity for language. She engages in sophisticated word play and has a knack for detail while her dry, irreverent humor adds a tone of irony and satire to her texts and thus exposes her critical eye for human follies. Finally, as to the form and structure of her fictions, Hensel has a liking for the unconventional.

Gipshut, the text I chose for my discussion of Hensel's Weiterschreiben, was published in 1999. Aside from her short prose narrative Tanz am Kanal, which was published in 1991, it is Hensel's second, longer post-Wende fictional work. The novel marks a turning point in Hensel's oeuvre in so far as it is the first of several fictional narratives with a distinctly local color quality and in which she uses a wide historical perspective, ranging from pre-GDR East German history up to the present. In Gipshut Hensel continues a method of story telling that she started with Tanz am Kanal, but which is not as dominant in the earlier narrative: the interweaving of her protagonists' personal stories with various aspects of GDR history. This technique allows her to expose the tragic aberrations of recent historical phenomena while at the same time reminding her reader of people's fallibility in the face of political and historical developments. ${ }^{46}$

\footnotetext{
${ }^{46}$ Two out of the three novels written after Gipshut, namely Falscher Hase (2005) and Lärchenau (2008), are similar to Gipshut as they, too, are fictional biographies that reach as far back as the years National Socialism and that extend into the present. Both
} 
Hensel's career as a writer started in the mid-1980s, and her first longer fictional narrative, Auditorium panoptikum, was published in 1991. The work is a playful, highly unconventional piece of writing in which Hensel closely imitates (and also parodies) the multi-genre, multi-plot technique of Morgner's famous montage novel Trobadora Beatrix. Like Morgner, Hensel takes her reader into a scurrilous and exotic world dominated by fantasy and imagination. Generally speaking, Auditorium panoptikum is a satirical spoof on East Germany's system of higher education, with which Hensel exposes the backwardness and stuffiness of academic life. With the many fantastic and fairytale-like elements, she mocks the natural sciences' reliance on verification and factual thinking. But the world of literature, too, is the victim of her irreverent humor. With the help of allusion and by mimicry, she pokes fun at Germany's literary tradition, and particularly at East Germany's literary scene. For example, the artists' colony Wielandshagen, founded by the young, aspiring poet Egmont Köhler, is a lampooning of the alternative scene of the Prenzlauer Berg poets. Egmont's secretary, Friederike, wrote a book about the Egmont's life that carries the telling title, "GUTE NACHT, DU DICHTER! - PROTOKOLLE UND AUFZEICHNUNGEN EINER SEKRETÄRIN" and is meant to parody Maxi Wander's famous collection of interviews with GDR women, Guten Morgen, Du Schöne. Aside from numerous references to Irmtraud Morgner's Trobadora, another victim of Hensel's humor is the GDR's most prominent writer, Christa Wolf, namely when Hensel includes in her novel her own

works are less interesting than Gipshut from the point of view of narrative technique. They are less playful than the earlier novel, and they lack its intricate structure and narrative complexity. 
version of Wolf's famous short story "Sommerstück." I7 Indeed, Auditorium panoptikum is one of the first and most imaginative examples of a Weiterschreiben of GDR-literature, but one that is based on parodying the country's literary tradition and ruthlessly exposing the flaws of the GDR's malfunctioning system.

Shortly after Panoptikum Auditorium, Hensel published Tanz am Kanal (1994), a short fictional narrative that many still consider her most successful work. The novella is Hensel's only attempt to date at using a first-person narrative perspective. While in Auditorium panoptikum she played with Morgnerian style of narration, the narrating in Tanz am Kanal is modeled after Christa Wolf's method of subjective authenticity, but it is more a parody than an imitation of Wolf's technique, one in which Hensel calls attention to the ambiguities of first-person narration. The story of Tanz am Kanal takes place only a few years after the Fall of the Wall and deals with issues typical of fictions about the post-Wende era-identity crisis, self-searching, and sense of disorientation. The narrator-protagonist is a young, homeless woman, Gabriela von Haßlau, who lives under a bridge by the canal in the fictional town of Leibnitz and spends her days writing her autobiography. Having left her old life behind (she is actually the daughter of a wealthy party official), Gabriela now literally writes a new identity for herself and fuses recollections of her past with descriptions of her present life on the streets. It soon becomes clear, however, that unlike Wolf's first-person narrators, Gabriela is not a very

${ }^{47}$ It is not just East German life, politics, and literature, however, that Hensel is caricaturing in this novel; she is poking fun at all of Western literature, history, and philosophy, including herself. Aside from directly refering to specific characters and settings from some of her earlier fictional texts, she also makes a cameo appearance as a so-called "sächsische Dichterin . . ., deren Texte aus der Heimat unter dem Titel HEILIMARSCH erschienen sind" (228). As the Hensel reader knows, Heilimarsch parodies the title of her 1989 collection of stories Hallimasch. 
reliable source of information. She is telling her story not to find out the truth about herself and her past but to create a new life for herself and also to tell a good story. As the narrative progresses, reality and fantasy become intricately interwoven so that it finally becomes impossible to tell what really happened. With Gabriela as the unreliable firstperson narrator, Hensel thus undermines the notion of autobiography as a form of confessional writing and truth-telling.

With Gipshut, Hensel continues her creative play with GDR themes and writing styles, but she now uses a distinctly different approach than in Auditorium panoptikum or Tanz am Kanal, and formally, it is the most creative of Hensel's later fictions. The novel also marks a turning point in Hensel's oeuvre in so far as it is the first of several fictional narratives in which she uses a wide historical perspective, ranging from pre-GDR East German history up to the present. Here, more than in any other of her later works, narrative structure and subject matter perfectly complement each other, and even the novel's rather chaotic finale, the way the story falls apart, makes sense in the full scheme of things. Central to Gipshut is the notion of disorder, thematically and also as an aesthetic principle, and at the same time, it is also a fundamental aspect of the novel's GDR-ness.

First, disorder is a main theme in Hensel's portrayal of both the GDR past and the years that followed the historical turn. In the story about Hans and his mother Veronika, the reader gets to see how during the years when the country was ruled by an authoritarian government, order was merely an illusion, a sham. That after the Wende life in the former GDR was literally turned upside down in more than one way is a fact that Germany is still dealing with today. Depicting different facets of the post-Wende chaos is 
a topic that emerges especially in the final chapters of the novel. Moreover, disorder is the guiding principle of Hensel's narrative method, a method that is defined by her often subversive play with GDR writing styles and with narrative traditions in general.

Proof that Hensel is indeed a writer whose work is very closely connected to the history, the life, and the literary traditions of Germany's old and new East can be found first of all in her comments about her writing and being a writer. Her remarks about why she writes and what she deems important in her writing not only show her as a regional writer, but they also provide important insight for our understanding of her work, including Gipshut.

\section{Kerstin Hensel on Writing and Being an East German Writer}

Kerstin Hensel is arguably one of East Germany's more noteworthy contemporary writers who unfortunately has not yet received the international recognition she deserves. That she is a very prolific and versatile writer-truly a literary jack-of-all-trades - is proven by her long list of publications, which in addition to numerous short stories and novels includes poems, short plays, operas, radio plays, television and film scripts as well as critical essays and feuilletons. In a conversation with Karl Deiritz and Rolf Stefanick for the Deutsche Volkszeitung, Hensel explains that expressing herself in different forms is a way of testing her limits. She is very much aware of the importance of what she calls gestalten (giving form to an idea). First comes the idea, and this idea requires - indeed dictates - a particular form since not everything can be said in a poem or in a story she explains in "Ich teste meine Grenzen aus" (9). 
Hensel has always been very willing to share her ideas about writing, about why she writes, and about what she considers the purpose of literature. As she once explained to Birgit Dahlke, her texts are non-traditional and challenging to read (she uses the adjective sperrig), they work on several levels and resist explication, and by talking about her writing, she wants to make her audience understand where she is coming from. She considers being a mediator between her texts and her readers as part of her profession (42). As far as her development as a regional writer is concerned, Hensel freely admits that she was very much influenced by the time and above all the place where she grew up, the East German province of Saxony. In her short reflective essay "Ohne Angst und an allen Dummköpfen vorbei," she remarks,

Ist mein Geburts- und erster Lebensraum Sachsen jene Wurzel?, die mein Gemüt, meinen Verstand geprägt hat und von der alles ausgeht, was immer ich auch anrichtete und anrichte.

Den ernsthaft-komischen Blick der sächsischen Dichter spreche ich mir zu - eine Prägung über Generationen von Lessing bis Leising. (54)

To her, there is a very definite connection between her personal background and her love for describing the ways of the world (Weltläufe) in their insanely monstrous outcomes. She also very much identifies with the different generations of writers from Saxony, the region where she grew up, and she feels that her sense of humor, her love for language play, and her fascination with the grotesque are traits that are peculiar to people

${ }^{48}$ This essay is tobe found in Hensel's Suddelbuch, which is a collection of personal essays, feuilletons, and poems, many of which are on the topic of writing and being a writer. The book was published in 1993, in response to the historical change of 1989/90, and it is her contribution to the heated debates about the past and future of GDR literature. 
from this part of the country. Equally influential, however, was the socio-political environment in which she grew up - the GDR during the sixties and seventies and her working class family background. Hensel was the only child of working-class parents. Both were well-adjusted conformists who had uncritically bought into party doctrine and resented anything intellectual. Already as a child, Hensel had a vivid imagination, and from early on, thinking up stories was for her a way of escaping the paralyzing drabness and conformism of life at home and in school.

The oppressive atmosphere at school where imagination and critical thinking were sacrificed in the name of molding the children into "good" socialists and complacent followers had an equally strong impact on Hensel's personal development. To escape the daily boredom at school, Hensel would conjure up wild stories about heroes who participated in the most fantastic and grotesque adventures. She writes:

Vom Betreiben dieser Überlagerungen, Realität - Bild - Traum, brachte mich nichts und niemand ab. Es rettete mich vor dem Alltag, dem Stumpfsinn der Klassenkameraden und der übrigen Leute. (55) These early years of her life had a great effect on Hensel's later development both as a person and as a writer. The drab and oppressive environment of her childhood years, rather than dulling her imagination, only spurred her creativity and fed her love for the fantastic and her passion for storytelling. Moreoever, her deep resentment of any kind of authoritarian structures is a theme that runs through all of her fictions. All protagonists in her longer fictional narratives in one way or other embody the destructiveness of a controlling personality. 
Hensel had always been a voracious reader, but it was not until her late teens that a close friend, herself a writer, introduced her to the world of literature. Some of the writers who particularly influenced her were Heinrich Heine, Berthold Brecht, and Volker Braun. Reading their works taught her that writing could be a means of expressing resistance and fighting back — “daß man sich gegen das Feste wehren kann” (Diana! 24). What at first had been simply an expression of her childish desire to escape reality now became a way of liberating herself from the narrow-mindedness and of voicing her opposition to the different forms of suppression and indoctrination she found herself surrounded by. Though she never was interested in politics, Hensel admits that her working-class background taught her to be critical of what she calls the lie of real existierender Sozialismus. In an interview with Klaus Hammer, she mentions that her desire to write was partly stimulated by the clash and the fundamental contradiction she perceived between official reports about the state of society and her own experience of what life in this society was really like (“Gespräch mit Kerstin Hensel," 94). Because of her personal experience, she was never able to share other writers' idealization of the working class, a quality that clearly distinguishes her from Volker Braun, Bertolt Brecht and also Christa Wolf. To her, the country's workers were not a class in the Marxist sense, but rather a collective mass devoid of opinion, without consciousness, and without a sense of mission.

Particularly insightful are Hensel's remarks about being a writer in the former GDR. During the early 1990s, when during the Literaturstreit literature from the former GDR received bad publicity, Hensel did not want her works to be labeled as GDRliterature primarily because of its downgrading as political writing. "Schreibt unsereiner 
Lebensgeschichten, werden sie als DDR-Geschichten überlesen und gewertet," Hensel complains ("Das Eine und nicht das Andere. Zum Thema: Schreiben in der DDR," 21). Her ironic wordplay with the expression "ïberlesen" (instead of the normal "gelesen") is directed against Western critics' indifference to the textual aspects of literature from the GDR. Thus, when in 1991, Klaus Hammer asked Hensel whether she would call herself a DDR-Autorin, she playfully evaded the question with the response, "Ich habe mich immer als die Autorin meiner Texte gefühlt" (“Gespräch mit Kerstin Hensel,” 99). Though her stories take place in the GDR and though she writes about people from the GDR, this does not mean that she writes about the GDR, Hensel explains to Hammer. During the early 1990s, this was a very significant distinction.

As already mentioned, Hensel is equally conscious of the importance of a writer's social and cultural background. Every literary work is in some ways shaped by the social and political environment in which it was written, Hensel concedes, and knowing about this can help the reader understand the characters' motivations and the sources of their conflicts. "Es gibt kein künstlerisches Werk, das nicht von der Gesellschaft, in der es entstand, geprägt ist," she writes, but at the same time, it is not some political message or ideology but the work's human appeal that is important in literature. ("Das Eine", 20). Hensel resents being called a political writer and does not want her texts to be considered pieces of social or political criticism. Reducing a literary text to a series of political statements is an oversimplification and banalization of its true meaning. Literature, for Hensel, is first of all invention, a product of the imagination - "Werk der Fantasie" (“Gespräch mit Kerstin Hensel," 98). She does not write to oppose an enemy or promote a certain ideology as is the case with politically engaged writers, Hensel explains to 
Dahlke. She simply tells what she sees ("Der langsame Blick," 51). Politics enters into her writing only in so far as it affects the lives of her characters, but it is never the purpose of her writing. Her real focus is history, and here is where she directly connects with the earlier generation of GDR writers, such as Christa Wolf, Uwe Johnson, and Christoph Hein. Like these writers, she wants show the workings of history on people's lives as a way of counteracting forgetting, because forgetting the past may mean repeating the mistakes of history. At the same time, though, she also realizes that a strict separation of politics and history is not possible. In order to be effective, she tells her reader in her essay "Das Eine und nicht das andere," art always has to be in opposition to the ruling system and contrary to the Zeitgeist (20). Thus, her texts are political in the sense that as pieces of art, they are meant to sensitize the reader towards the different wrongs in this world.

Power relations are Hensel's Stoff (the dominant theme in her writing), and with her writing, she hopes to increase her readers' awareness of issues of dominance and oppression. Each writer, she says in "Das Eine und nicht das Andere," has only one thing ("nur eines") to tell, and this she does again and again in different ways. It is important, however, that this one idea be meaningful and have historical dimensions (22). With every new text, the writer must surprise the reader by finding new ways of saying "das Eine." She must make herself understood not by preaching but through the creative manipulation of language and the method of her storytelling. In response to the debates of the literary battle, Hensel demands that a literary work be judged by the general human appeal (“das übergreifend Menschliche”) of its subject matter. At the same time, however, a text's form and artistic presentation play an important role when evaluating its 
merit since the creative manipulation of language and the deliberate shaping of a text's structure are the elements that make a piece of writing truly effective and distinguish it as $\operatorname{art}(20)$.

Hensel calls her method of writing erfahrene Erfindung (experienced invention), with a clear emphasis on the idea of Erfindung. Indeed Hensel's notion of erfahrene Erfindung is very much like Christa Wolf's subjective authenticity, and like Wolf she insists that the world depicted in her fictional narratives, as authentic and true to life as it may seem, is first and foremost a product of the imagination and not just a copy of reality. ${ }^{49}$ Moving back and forth between the real and the imagined without having to leave the borders of her desk is for her the essence of writing ("Ohne Angst," 56). On the one hand, there is a dream-like quality to her writing — she calls it "traumhaftes Erzählen"- but this seemingly spontaneous and associative narrating is always counterbalanced by what she calls Gestalten and bewusstes Schreiben, by a continuous concern with narrative form. Thus, being creative for Hensel always means design and control combined with invention and intuition. ${ }^{50}$ Directly related to this particular style of narrating is the way Hensel combines realistic detail with various fantastic, fairy-tale like elements. In her conversation with Klaus Hammer, Hensel repeatedly emphasizes the

\footnotetext{
${ }^{49}$ Roswitha Skare, too, mentions this similarity between Hensel's and Wolf's aesthetic principles. But the important difference between these two writers and their works is that Hensel does not insist on her presence in her texts as author. Insisting on a strict separation between her private self and the voice speaking in her texts also means that she is rejecting the kind of authority that during the history of the GDR and its literature was imposed on the country's writers ("Identitätskonstrukte in Texten junger ostdeutscher Autoren nach 1989/90. Zu Kerstin Hensel: Tanz am Kanal (1994)," 105).

${ }^{50}$ In her conversation with Elke Erb, Hensel explains the spontaneous aspect of her writing. She does not think about a topic, nor does she consciously file it away in her memory. She explains, "Es ergibt sich irgendwann, und dann weiß ich, daß ich es gespeichert hatte" (37).
} 
importance of Fantasie (imagination) for her writing. This emphasis on the imagination as a source for her writing is a directly related to the fact that she grew up in the GDR, in a country where one's freedom was so limited. "Hierzulande, wo so vieles abgeschlossen schien, war die Fantasie das einzige, was sich über all das hinwegsetzen konnte. Im Augenblick Welt zu zeigen," she explains to Hammer (105). At the same time, mixing different realities and thus calling attention to the fictionality of her narratives is an important aspect of Hensel's narrative method and it shows her alliance to two other writers, Irmtaud Morgner and also Bertolt Brecht. Hensel wants her readers to know that her texts are just make-believe. Like Brecht in his epic theater, she wants to keep the reader at a distance, invite her to ask questions about the characters and their stories, and thus incite critical thinking. ${ }^{51}$

As already mentioned, growing up in a repressive environment spurred rather than inhibited Hensel's creativity and her development as writer. Similarly, once she decided to be a writer, dealing with the government's censorship never really was an issue for her. In fact, she considered the lack of freedom and the resistance to be not an obstruction but a gain, challenging and inspiring at the same time. In general, censorship forced writers to be creative and imaginative in their use of language, Hensel writes in "Ohne Angst," “Als es noch eine DDR gab, konnte ... geschaffen werden. Und zwar eigene, anspruchsvolle, hochkaratige Werke, über die man, . . , sprechen wird” (59). Hensel's vivid imagination, the many fantastic elements in her fictions, and the fact that she was still relatively unknown during the mid-eighties turned out to be an advantage as far as

${ }^{51}$ This connection to Brecht's epic theater was also pointed out by Jill Twark in her discussion of Gipshut. Humor, Satire, and Identity. Eastern German Literature in the 1990s, p. 276. 
the issue of censorship was concerned. Already her first play, Katzenbericht, which she published as a short story with the same title, kindled a heated debate because of its bizarreness and violent content. ${ }^{52}$ The story was attacked as a piece of fascist literature, was deemed dangerous and sick, and even caught the attention of the Stasi ("Ohne Angst," 56/57). ${ }^{53}$ Rather than discouraging her, the general uproar only heightened Hensel's desire to write. “[D]ieser Angriff öffnete mir wieder eins der verschlossenen Tore im Kopf," she told Erb. "Daß die Welt ja nicht so ist und — daß sie eben so ist, . . .? (44). And with this new insight about how things are, she kept on writing. Never having taken seriously the Stasi's threats and restrictions, Hensel didn't feel that the disintegration of the country's repressive political system greatly affected her situation as writer. With her typical outspokenness, Hensel remarks that the only difference after the Wende is that censorship of the state became replaced by censorship of fashion. Instead of ideology, it is now taste that rules ("Ohne Angst und an allen Dummköpfen vorbei," 59).

I mentioned earlier Hensel's evasive response to Klaus Hammer's question whether she considered herself a GDR writer. Hammer's interview dates from 1991, but as time went by and the literary debate had exhausted itself, Hensel became less opposed to the idea of being thought of as a regional writer. In a conversation with Birgit Dahlke, she admits that the regional quality of her texts is one of their defining characteristics. Having spent thirty years of her life in the GDR had undoubtedly shaped her writing, she tells Dahlke. "Du schreibst immer aus deiner Herkunft heraus," she remarks. "Worüber

\footnotetext{
52 "Katzenbericht" was published in 1989 in the short story collection Hallimasch.

${ }^{53}$ Hensel told Elke Erb that one day, men from the Stasi appeared at her door claiming that they could use her help. In her naïveté, she simply ignored their request and they never came back.
} 
du Bescheid weißt, darüber hast du am meisten zu sagen, und nur das wird dir wirklich überzeugend gelingen” (“Der langsame Blick,” 43). And since life in the GDR is what she knows best, her fictions depict a reality-experiences, social-political environment, and traditions - that is specific to life in the East. But experience simply gives the initial impulse; it is the imagination that provides the shape (Diana! 38) ${ }^{54}$ When explaining to Erb the connection between reality and imagination, Hensel chooses the word "gelebt" rather than "erlebt" (lived rather than experienced), which is her way of stressing that she is not writing about her experience but about life in general-life as it is being lived (my emphasis, 45).

Hensel's comments reveal how much having lived in the GDR has shaped who she is as a writer, and what she writes about. Also, with her interest in how history works on people's lives, East Germany's history in particular offers an abundance of material to work with: Nazism, the horrors of the Second World War, the almost fifty years of Real existierender Sozialismus, and the life-changing effects of the Wende. Indeed, the historical change spurred Hensel's creativity, as proven by the number and the length of the works that follow Gipshut. A fact that further supports calling Hensel a regional writer is that all of her narratives are set in East Germany, mostly in the provinces of the Mark Brandenburg or rural Saxony. Aside from the fact that Hensel likes to use real places as the backdrop for her fantastic and often grotesque stories, her fictional worlds are full of specific detail about everyday life in the old and the new East. Whereas in Gipshut Hensel moves from almost the beginning of the GDR's history to the present, in

\footnotetext{
${ }^{54}$ In her conversation with Elke Erb, Hensel explains that for her, writing is closely connected with getting to know people - "Menschenkennenlernen." The impetus to write is not a conscious decision. A topic suddenly materializes, but it is always in some way connected to the people she meets during different times in her life (37/38).
} 
the novels that follow, she ventures even further into the past, to the years when Germany was under Nazi rule. There is also one other way in which Hensel shows her indebtedness to the former GDR and its literary intellectuals, which is expressed in the form of a continuous questioning of the idea of historical and social progress.

\section{The Disorderly World of Gipshut and Hensel's Disorderly Narrating}

My discussion of Hensel's aesthetics of disorder in Gipshut as a form of Weiterschreiben of GDR-literature will be divided into four major sections. I will begin with a brief summary of the novel's two plots and briefly elaborate on the idea of Gipshut as a piece of regional literature. Next I will discuss the tension between order and disorder in the novel's structure. While Hensel carefully establishes numerous connections between the two narratives, she also gradually undermines this sense of connectedness, either by exposing the artificiality of her method or by transforming these connections into false tracks. Whatever sense of order may have emerged is slowly destabilized as the novel progresses. The way Hensel foregrounds the novel's constructedness and her ironic play with readers' expectations remind one of Irmtraud Morgner's creative storytelling in Trobadora Beatrix while inviting comparisons with Brecht's epic theater. Another important aspect of Gipshut's disorder is Hensel's choice of narrative perspective. Both of the novel's stories are narrated in the same third-person omniscient voice, which with its distanced and matter-of-fact reporting conveys an, albeit false, sense of objectivity and reliability. The narrator's refusal to explain or comment on the novel's many unusual and bizarre events is one of the main sources of Hensel's ironic humor and once again, there is a noticeable connection to Irmtraud Morgner. The most 
creative representation of disorder, however, is the novel's temporal structure and Hensel's play with story time. In Gipshut, time is literally out of joint, and in the novel's final sections, as the narrator's temporal references become increasingly vague, story time gradually disintegrates. There is no way of telling whether months, weeks, or years have passed. From the point of view of the narrating, however, this timelessnesstimelessness in the sense that time no longer matters - is quite appropriate. It perfectly matches the novel's contrived and implausible ending and conveys the idea that everything is in limbo.

Several critics allude to the idea of disorder as a central theme and narrative strategy in Gipshut by pointing out the novel's many grotesque elements, its subversive humor, and Hensel's ironic play with language. Jill Twark, for instance, talks about the different ways in which in Gipshut's fictional world "bodies, genres, and linguistic quirks are bound together by their grotesque bursting of expectations and the production of ambiguity" (Humor, Satire, and Identity. Eastern German Literature in the 1990s, 246). Though Twark does not specifically mention the idea of disorder, “bursting [readers'] expectations" and "ambiguity" are both means of destabilizing a text and are manifestations of disorder. Likewise, Antje Baumann's analysis of the comical —“das Komische"-in Gipshut deals, albeit indirectly, with the concept of disorder. Baumann argues that by using "Komik," Hensel causes an other world-“eine 'Gegenwelt' oder eine "verkehrte Welt"”- to emerge ("aufscheinen") from beneath the novel's surface reality ("Das Komische begreifen, ohne es fassen zu können: Gegenwelten in Gipshut," 
121). ${ }^{55}$ This kind of text-subtext dichotomy with which Hensel alludes to the existence of diametrically opposed realities is one of the distinctive characteristics of the disorder in Hensel's narrative method. What these critics fail to note, however, is that undermining a text's surface meaning, deliberate ambiguity, and the play with different realities are strategies frequently used by writers from the GDR, who used them as a way of avoiding censorship. Playing with different and often conflicting realities and thus confronting the reader with the fact that things are not always what they seem is a widespread strategy throughout GDR-literature from Christa Wolf's Der geteilte Himmel to Christoph Hein's Horns Ende. Hensel's sensitivity to the power of words, whether expressed in doublespeak, allusive language, or irony, groups her with the best of the GDR's writers.

\section{A. Two stories in one: A divided world}

Disorder in the form of dividedness is the guiding principle of the novel's composition. Gipshut is a novel with two storylines and as the narrating keeps switching back and forth between them, the reader is able to participate in both fictional realities simultaneously. Most of the action is set in rural Saxony, and only during the final chapters does the locale shift to the Berlin of the post-Wende era. At the same time, however, each story has its own set of characters and its own temporal setting. The first and longest of the two narratives comprises the biographies of Veronika Dankschön and her son, Hans Kielkropf. Covering a time period from the early fifties until the late 1990s, their story is primarily a kaleidoscope of life in the GDR during the time of Real

${ }^{55}$ Another very insightful study of Hensel's humor and the importance of the grotesque in Gipshut can be found in Lyn Marven's Body and Narrative in Contemporary Literatures in German. Herta Müller, Libuše Moníková, and Kerstin Hensel. 
Socialism, though it also provides some insight into the problems brought about by German reunification. The second story, in contrast, is set in the post-Wende East and takes place eight years after the historical turn. It tells about the unusual adventures of two East German geologists, Anna Fricke and Paul Norg, who are on a mission to find the source of an underground volcano in the Mark Brandenburg. Writing fictional narratives that span different historical and/or political phases and where the narrating moves back and forth between the past and present is a well-established tradition in GDR literature, as mentioned earlier, but Hensel gives this method her own creative spin. Unlike in Christa Wolf's Kindheitsmuster or Uwe Johnson's Jahrestage, for example, where we have the past presented as personal memory, Hensel chooses a detached narrator who, playing the role of a storyteller, has no personal interest in what is being relayed. For that matter, it could even be an impersonation of Hensel herself.

Mother and Son and the Blessings of realem Sozialismus

Veronika Dankschön's short biography is a rather unusual mixture of comedy and tragedy, and as such is a showcase of Hensel's dry sense of humor. When we first meet Veronika, she is barely seventeen. She is riding her bicycle to the Siethener See, a lake in rural Brandenburg, where she hopes to find relief from the summer heat and from some rather persistent stomach pains. Though the reader very quickly realizes the true nature of the girl's mysterious stomach pains, Veronika is completely oblivious of her state. As she is swimming in the water, Veronika gives birth to a boy, Hans, the novel's protagonist. Veronika is a good-natured and kind young woman, but she is also unusually naïve, perhaps even slightly retarded. (The degree of her mental debility is never clearly 
established.) Her story can be summarized in a few short strokes: She has a job as an unskilled worker at the local supermarket, the Konsum, where she is delegated to stacking goods. Having been abandoned by her parents, she considers the Konsum her family. Technically speaking, the child she gave birth to is the product of rape, but in reality, naïve Veronika is more puzzled than traumatized by the boy's conception. The child's father, Gabelstapler Jochen, reluctantly agrees to marry Veronika, but their marital happiness is short-lived. Jochen soon becomes frustrated with the squalor of their life and with Veronika's simple-mindedness and decides to leave his family when Hans is still an infant. From now on, Veronika's life evolves around working at the Konsum and raising her son. The boy soon begins to develop several strange habits, one of which is eating newspaper. Once he is older and becomes aware of his mother's simple-mindedness, he shuts her out of his life. Veronika, either deliberately ignoring or unaware of her son's resentment towards her, dotes on him. She also clings to the hope that some day Jochen, still the great love of her life, will return and rescue her from her loneliness. Shortly before the Fall of the Wall (and thirty-nine years after Hans's birth), however, Veronika decides to make an end to her miserable existence. Coming back from a brief vacation, she hangs herself - with the same rope that, years ago, she had stolen from the Konsum as a surprise Christmas present for Jochen.

Though strictly speaking, Gipshut has four protagonists, Hans Kielkropf is the focal character. We follow Hans's life from the moment of his unusual underwater birth on August 21, 1950, till some afternoon roughly forty-eight years later, when from the balcony of his apartment he watches a volcanic eruption over the city of Berlin, a disaster that he could have prevented. Hans stands out because of his eccentric and abrasive 
personality, and it is he who bears the brunt of most of Hensel's ironic humor. From childhood on, Hans considers himself superior to those around him. He is convinced that because of his unusual birth, he is destined to make history. Furthermore, he is easily impressed, loves big words, and is fascinated by the idea of history's progress. He soon becomes an ardent follower of the Socialist Unity Party, a fact that is not the result of careful thought. The narrator offers two explanations for Hans's political fervor. One reason could be his constant exposure to socialist propaganda as a result of his childhood passion for playing with newspapers. Another may be that he was always inhaling the Güllengase, the penetrating fumes from the neighboring pigsties that filled his room when the wind was right. Whatever the reason, little Hans turns out to be an avid and brainwashed socialist who is fixated on the utopian notion of der neue Mensch. With the passion of a religious fanatic, he makes it his mission in life to lead the human race towards perfection. Because of his talent at regurgitating socialist propaganda and his unwavering enthusiasm, and certainly not because of his intellectual faculties, Hans lands a job as a journalist with the local newspaper. ${ }^{56}$ But for one reason or other, inspite of all the enthusiasm Hans shows for fulfilling his mission and serving historical progress, all of his endeavors end in disaster. After the collapse of real existierendem Sozialismus, he finally finds a job helping to tear down the toxic asbestos paneling from the walls of the Palast der Republik, the building that used to house the GDR Volkskammer (the country's

\footnotetext{
${ }^{56}$ All of the scenes depicting Hans's education and professional training are filled with ironic humor and satire, and their comedy underscores the clash between Hans's grand dreams and his own fallibility and ineptitude. Most powerful are the scenes describing Hans's "Arbeitspraktikum" at the city hospital in Leipzig (116-131) and those that depict his "Ehrendienst" with the Nationale Volksarmee (142-153). The ironic humor and satire in these scenes highlight the vanity and absurdity of Hans's strivings while at the same time making a farce of the country's political system.
} 
socialist government). Soon, Hans contracts asbestos poisoning while working in the building — the symbolism here is only too obvious. But resilient and obviously immune to the evils of socialist ideology, he makes a miraculous recovery and tenaciously clings to his beliefs. After the Palast is demolished and replaced by a new structure, the Berliner Stadtschloss - symbol of the Berlin Republic and the new Germany - Hans is assigned to a new job, now in the basement of the building, where he arranges and stores plaster imitations of sculptures representing important historical figures. ${ }^{57}$ Though he feels out of place in the new East, Hans never gives up hope that some day he will fulfill his destiny and make history. His wish finally comes true when, with him as a facilitator, an apocalyptic volcanic eruption spreads fire and ashes over parts of Berlin.Though, the world will never know that he caused the disaster.

${ }^{57}$ The mention of the Berliner Stadtschloss is one of the many instances when Hensel merges fact and fiction and rewrites history while simultaneously mocking the city's post-unification building craze. One of the plans for the new Berlin has been to replace the meanwhile demolished Palast der Republik with the building that originally stood in its place before WWII, the Berliner Stadtschloss. (The Stadtschloss, once the residence of Prussian rulers and symbol of the German Kaiserreich, was severely damaged during the war and in 1950 was destroyed by the GDR government.) In 2008, the Italian architect Franco Stella developed a highly ambitious and expensive plan (552 million Euro) for the reconstruction, which started numerous fierce debates among the city of Berlin, its citizens, and the German Federal government. Originally, construction was to start in 2010, but as a result of the European financial crisis, it was postponed until 2013. Meanwhile, because of higher building costs, the price for the construction rose by another 38 million to 590 million Euro, and this led to yet another round of heated debates between the different fractions in the Bundestag. On July 6 of this year, however, the budget committee of the Bundestag finally approved the planned reconstruction with the exception of the baroque enclosure of the cupola, the three planned portals, and the rooftop café, which at this time will not be built. The construction is now supposed to begin in 2014. [http://www.morgenpost.de/berlin-aktuell/article1693625/Grünes-Lichtfür-Berliner-Stadtschloss.html. accessed August 5] 
Anna and Paul and the Hidden Volcano

Parallel to the story of Hans and his mother, Hensel develops that of two geologists, Paul Norg and Anna Fricke. Their story begins on a hot day in August 1997coincidentally at exactly the same location where forty-seven years earlier, Veronika gave birth to Hans - and it ends several months later. The two geologists are on a mission to investigate recent, unusual volcanic activities in the Mark Brandenburg, and they hope to find proof for the existence of a subterranean volcano. The idea behind the project is that it should be a German-German collaboration. Paul is chosen as the East German representative of the team while Anna is sent from the institute in Garmisch Partenkirchen, West Germany. As it turns out, however, Anna is also from East Germany. After the Wende, she had moved to the West because of better job opportunities, but knowing how East Germans were often discriminated against in the West, she kept her true place of origin a secret. Ironically, then, the team that is meant to represent the two Germanies is in fact only an East German team. ${ }^{58}$ Shortly after Anna and Paul arrive at the lake strange things begin to happen, but especially during their exploration of the terrain. Time comes to a standstill, nature freezes over, they encounter various unnatural phenomena such as a singing snake and a talking plant, and finally, they are held hostage by the story-hungry fairy Pschespoldnitza, a figure out of Slavic mythology. In order to appease the angry fairy, Anna tells Pschespoldnitza her life story while Paul, an utter failure at telling stories, has to spin flax into linen. When the nightmare is finally over and everyday reality has returned, Anna and Paul, noticeably

${ }^{58}$ Through her ironic play with the label "deutsch-deutsche," Hensel not only exposes the absurdity of this label, but she also satirizes the whole concept of such bi-German teams. Especially in the East, such East-West cooperation was often interpreted as patronizing. 
changed by their experience, fall in love. Their story has two climaxes: the consummation of their love in the Siethener See and the discovery of the volcano's crater in the basement of the Palast der Republik in Berlin.

Hans plays a key role in the team's discovery of the volcano's epicenter, and it is here where the two storylines briefly intersect. Though Anna and Paul have reached their goal, their efforts turn out to be in vain. Because of funding issues, the geological institute in Garmisch decides to drop the project and the sensational discovery is never made public. The two scientists lose their job, but not really too worried about what happened, they quickly change gears and begin working as publication and communication experts - coincidentally in no other place than in the newly built Berliner Stadtschloss, where unbeknownst to them, Hans is working in the basement. They pursue their new goal, helping to transform Berlin into Germany's new and modern metropolis, with the same dedication as their search for the volcano. Still, the driving force behind the Anna/Paul plot is gone. Their story quickly peters out and, to the disappointment of many, ends inconclusively. Since in neither of the two stories does the narrator give any indication of when the volcano's eruption occurs, there is no telling whether the two scientists were killed in the blast. ${ }^{59}$

With the novel's two plot strands Hensel gives shape to one of the defining aspects of life in the post-unification East-its dividedness. It is her way of reminding her reader that as far as the years following the historical turn are concerned, there is not just one story to tell. The old way of life including the old customs and patterns of thought did not all of a sudden disappear or become replaced. Instead, they continued to exist side-

\footnotetext{
${ }^{59}$ In a later part of this chapter, I will return to the question of how one may interpret this strange ending of the Anna/Paul plot and what might have been Hensel's purpose.
} 
by-side with the new, the Western way of life, a fact that often led to a sense of disorientation and even fragmentation especially among the country's older citizens.

\section{B. Blinde and Not-so-Blinde Spuren or the Order of Disorder in Gipshut}

As the novel's two narratives pull the reader in different directions, Hensel uses a number of strategies to offset this kind of internal division and create a sense of connectedness. Interestingly, many of these links are either misleading or so obviously artificial - merely a sleight of hand - that whatever sense of coherence may emerge is merely temporary and superficial. The two most noticeable ways in which Hensel ties together the two stories are the novel's intercalated structure and her use of locale. Another, more subtle technique of connecting the two narratives is the insertion of numerous cross-references, which the reader finds scattered throughout the novel. In her review of Gipshut for the Neue Züricher Zeitung, critic Katharina Döbler mentions how with these "Querverweisungen," Hensel tricks the reader into assuming that there are some meaningful connections between the two narratives, when in reality these crossreferences are only "blinde Spuren," tracks that lead nowhere. The most interesting and intricately devised blinde Spur is the inclusion of Paul in Hans's biography, which is also one of the more noteworthy instances of her ironic method of narrating.

The most obvious way in which Hensel creates a sense of connectedness between Gipshut's two storylines is by having the narrating alternate between them, thus allowing the reader to watch both stories unfold simultaneously. Every time the narrating shifts to the other narrative or skips to a new episode within the same storyline, this change is accompanied by a blank line in the text. On the one hand, such continuous narrating and 
the lack of chapter breaks emphasize the idea that these two narratives are interconnected, and they reinforce the notion of the novel as a single piece of text. It also grants the reader a unique kind of double vision as it allows her to simultaneously be part of two different realities and consequently evaluate each fictional world in light of the other. On the other hand, the constant back and forth is disruptive and disorienting. It makes the reader aware of the novel's constructedness and thereby distances her from Gipshut's fictional world.

One of the more deceptive schemes Hensel uses to create a (false) sense of order is the characters' chance meeting at the Palast der Republik. The scene where Anna and Paul knock at the door of the Palast der Republik and Hans lets them in and leads them into the basement where together they discover the volcano's epicenter marks the one and only time in Gipshut when the novel's two storylines converge. In reality, though, this merging of the two storylines is merely a sleight-of-hand, an ironic play with readers' expectations, as immediately after the scene, the two storylines diverge again. The three characters go their separate ways never to meet again. Ironically, however, and this is once again one of Hensel's storyteller ploys, it just so happens that all three characters end up working in exactly the same place; only now, the Palast has been replaced by the Berliner Stadtschloss. As Hensel continues weaving the threads of these stories and Gipshut's narrative quickly moves towards its chaotic ending, the three characters' meeting in the Palast der Republik turns out to be more important than the reader is led to think, inasmuch as it sets the scene for the novel's fantastic and chaotic ending. Had Hans not witnessed Anna and Paul's discovery of the hidden crater, he would never have conceived of facilitating the volcano's eruption. 
More involved and certainly more deliberately contrived is Hensel's use of locale as a means of ironically undermining the idea of order in Gipshut's fictional world. For example, the symmetry of location at the beginning of Gipshut-both stories begin at the Siethener See - gives an impression of connectedness between the four characters' fates. This commonality is, however, immediately undercut by the fact that as a result of the historical turn, Anna and Paul's East Germany is worlds apart from the one of Hans and Veronika. ${ }^{60}$ Similarly, as mentioned before, at the end of the novel, Hans, Anna, and Paul end up living in Berlin and are even working at the same place. The temporal gap between the two storylines is closed in the Palast der Republik episode, when the narrative tense in Hans's story changes from past to present tense. At the same time, however, this sense of connectedness between the two narratives is undercut by the fact that Hans's Berlin is worlds apart from Anna's and Paul's. Disoriented and disillusioned by the sudden change, Hans has withdrawn from the world while still holding on to his old dreams while Anna and Paul quickly adjust and embrace the excitement and the newness the city has to offer. In the narrating of Gipshut, it turns out that strategies generally used to give the impression of order within the fictional world-interweaving of different strands of plot, merging of different storylines, and choosing the same setting - have exactly the opposite effect and ironically bring out poignantly the disorder of the novel's fictional world.

Another technique with which a writer can create the illusion of coherence and interconnectedness within a narrative is the insertion of cross-references, and indeed, Hensel's reader will find numerous cross-references scattered throughout the novel. But

\footnotetext{
${ }^{60}$ Hensel's ironic play with the idea of symmetry is further strengthened by the stories' identical beginnings, "Im August ....".
} 
again, Hensel uses them creatively and makes them part of her ironic method of narrating. As Döbler points out, Hensel uses them to deceive the reader and lead her onto false tracks. One of the more interesting and creative examples of Hensel's game with cross-references is Paul and his cameo appearances in Hans's story. The way Hensel shifts back and forth between negating, affirming, and then finally negating the notion of some deeper connection between the two male protagonists is the most ambiguous and ironic among the different cross-references.

At first, it seems that because of fundamental differences in the men's personalities, the inclusion of Paul in Hans's biography is merely a technical move without any deeper meaning. It is quite obvious that the relationship between young Paul and Hans is completely one-sided. While Hans idolizes the boy and in his bizarrely twisted way even thinks of him as his progeny, Paul either totally ignores Hans's attention or simply endures the man's obtrusive behavior. There is no similarity in the two men's personalities. The older Paul, we soon find out, has no interest in politics and in general is the quiet and apathetic type while the defining characteristics of Hans are his political fervor and his enthusiasm for changing the world. Not only do Hans's efforts to convince the young Paul of his unique importance for the future good of mankind remain futile, but they also breed in the boy a life-long distaste for political action. And to add insult to injury, when years later in the Palast episode Paul and Hans cross paths again, Paul claims not even to remember their earlier encounters. "[I]n seinem ganzen Körper scheint nicht eine einzige Information gespeichert zu sein von dem, was Hans zeit seines Lebens für diesen Menschen getan hat," the narrator remarks (201). There is no doubt 
that Hans's efforts to transform the boy into the prototype of the neue Mensch bore no fruit.

But what about the older Paul, the Paul we meet in Gipshut's other story? Due to the novel's unusual structure, certain facets of Paul's character can be understood only retrospectively. In other words, the full meaning behind what the older Paul says early on in the first sections of his and Anna's story is realized only much later, after the reader has learned of Hans's strange relationship with young Paul and his bizarre notions about the boy's destiny. Once this gap is filled and the reader had plenty of opportunity to listen to Hans's ideological blabber, some striking similarities between Hans's language and that of the older Paul suddenly begin to emerge.

The first indication of such a connection between the two characters appears in the first episode of the Anna/Paul plot - a connection, however, that cannot be noticed until a second reading of the novel. Shortly after their arrival at the Siethener See, Anna tersely reprimands Paul for addressing her with the old fashioned and, in her view, sexist expression "Fräulein.” Paul, ignoring the hostility in Anna's voice, defends his word choice as follows:

Das Wort Fräulein . . . kennzeichnet die Vielfalt der Bezeichnungsarten, sowohl der Gattung als auch des Begriffes Frau - sein Sie froh, daß Sie diese Vielfalt genießen können, noch! Und auch ich möchte sie genießen, denn das ist meine Zeit, jetzt, wo uns die Welt offensteht. Endlich darf ich diese Vielfalt sprechen, Fräulein! Frau, Weib, Mädchen. Wir werden Geschichte machen als von allen Zwängen erlöste Menschen! Wir sind die Zukunft. (10) 
Paul here is spewing out words that resound with the nonsensical, stilted, and convoluted language of Hans's speech. Indeed, phrases such as "das ist meine Zeit," "Wir werden Geschichte machen," and "Wir sind die Zukunft" are almost verbatim taken from Hans's sermons to the helpless young Paul later in the novel. This echoing of Hans's language is even more pronounced and indeed downright hilarious in the second Siethener See episode when, in eager anticipation of his and Anna's first lovemaking, Paul tries to boost his self-confidence with the idea that he certainly is "der Neue Mensch, ein Mittler seiner Zeit.” It simply has to be this way, Paul reassures himself; it is a given - “[E]ine Satzung und Richtschnur, ein Gesetz, das er noch erkennen mußte" (174). These are Hans's words and Hans's thoughts, but the sexual context to which Paul applies Hans's speech makes a mockery of the older man's ideological blabber.

In fact, as the narrative progresses, Hensel continues to exploit this incongruity between language and meaning with grotesquely funny results. Invigorated by the prospect of their sexual union, Paul is finally able to overcome his life-long silence and words suddenly start pouring out of him. “Aus ihm heraus spricht bereits der Mensch, den man von ihm erwartet," the narrating voice tells us, once again parodying Hans's language (175). And only a few pages later, as if to reassure the reader that Hans did indeed make an impression on Paul, Hensel has Paul apply bits and pieces of Hans's socialist rhetoric when contemplating his sexual prowess. The irreverently ironic wit and sarcasm of the passage make it worth quoting in full.

... Obwohl Anna husten muß, schwimmt Norg ihr jetzt bei in einer Weise, die im Freibad nie hätte stattfinden können. Wo er eben noch von Größe nichts wissen wollte, ragt jetzt beinhart das Ziel. 
Hier ist der Ort, an dem alles entsteht und geschieht. Hier ist der Ort, an dem Paul Norg begreift, was es heißt, über die Norm gewachsen zu sein. Diese Entdeckung läßt ihn noch einmal um zwei Zentimeter zulegen, freilich nur an der Stelle, die Anna Frickes Wärme schützt und anfacht, ... die sich einzig und unerreichbar gibt, ein Pionier der Gegenwart und Zukunft. (my emphasis, 177)

The satirical humor in this scene is self-explanatory, but its victims are not just Hans and the meaningless slogans of Real Socialist doctrine. The passages cited above show how Hans's efforts at indoctrinating the young Paul have not been completely in vain after all. Paul does indeed remember the man's words, though he does so out of context, which leads to a humorous distortion of their original meaning and makes a farce of Hans's efforts at improving the world. Paul is certainly one of the more entertaining and noteworthy examples of Hensel's play with blinde Spuren because of the way in which Hensel ends up undermining her own method. With Paul's character she both negates and affirms some connectedness between the novel's two worlds. Paul uses Hans's speech, but the way he applies it shows that he never understood the meaning of Hans's words and, even worse, they make a farce out of Hans's ideological sermonizing.

Critic Jill E. Twark compares the novel's intrinsic ambiguity and Hensel's fondness for creating false expectations in her readers to a technique in the visual arts used by René Magritte and M.C. Escher. She writes, “[t]he novel’s composition and characters resemble paintings by the artist René Magritte or drawings by M.C. Escher that fool the observer by appearing logically constructed, but are actually trompe l'oeilsdecoration (246). Sending her readers on false tracks (blinde Spuren), deliberately 
frustrating their expectations, or simply leaving them guessing (as happens with the novel's ending) is part of Hensel's tongue-in-cheek play with narrative form and with the way we read. The symmetry of the locale at the beginning and the end of the novel, and the inclusion of Paul in Hans's biography are deceptive ploys and playful adornment that emphasize rather than diminish the clash between the two fictional worlds. The ambiguities they create are like signposts warning the reader that in Gipshut things are not always what they seem. Such deliberate undermining of order or connectedness between the two narratives is an essential component of Hensel's aesthetics of disorder. It is a method with which she creates the same effects that we know from Brecht's epic theater and which characterizes Irmtraud Morgner's fictions. Aside from distancing her reader from the fictional world by making her aware of its artificiality, Hensel, like Brecht and Morgner, intends to entertain and simultaneously educate her reader. With the many false tracks that she so carefully builds into the novel's chaotic universe she reminds us readers how much we are at the mercy of forces that are beyond our controla fact that is especially true in the East Germany of the late 1990s.

\section{Hensel's Play with Time in Gipshut}

With the GDR's turbulent history and its dramatic effects on people's everyday life, time - the past, the present, and the tension between them - had always been an important theme in GDR literature. The sudden collapse of the socialist government and the dramatic changes in the country's economy and socio-political environment as a result of German reunification renewed East German writers' interest in the topic of time. Time, the change in the times, and the problem of adjusting to social, political, and 
ideological changes are the subjects of many a post-Wende East German fictional narrative and they are also major themes in all of Hensel's post unification fictions, from Tanz am Kanal to Lerchenau. In her novel Gipshut, however, the topic of time takes on a further dimension. As an essential component of her narrative strategy, Hensel's creative play with the novel's temporal structure and story time (erzählte Zeit) has a central role in her aesthetics of disorder.

One of the more creative aspects of Hensel's play with time is the way in which she coordinates and interlaces the temporal settings of Gipshut's two stories. As mentioned earlier, the two storylines begin almost exactly forty-seven years apart, but as the novel progresses, story time in the Hans/Veronika narrative gradually catches up to the present of Anna and Paul's story until in the Palast der Republik episode both timelines converge. With the narrating switching back and forth between the two temporal dimensions (and implicitly between the two historical settings), Hensel gives the impression that past and present actions were occurring side-by-side-much like parallel worlds. Participating in two different temporal realities at the same time allows the reader to evaluate the past in light of the present while seeing how the present is still permeated by the past. ${ }^{61}$ To further emphasize this past-present dichotomy, Hensel assigned a very specific narrative tense (Erzählzeit) to each storyline. The two biographies, which take the reader back to life in the GDR, are narrated retrospectively in the past tense whereas Anna's and Paul's story is delivered in a kind of historical present, where the narrating is simultaneous with the experience narrated. As soon as the temporal

${ }^{61}$ Antje Baumann comments on Hensel's unconventional treatment of time in Gipshut and remarks that "die Verknüpfung der beiden Erzählstränge . . . während der LektüreZeit ein wiederum neues Gefüge von Zeit (und Raum) entstehen lässt” (127). 
gap between the two narratives is closed, however, past tense narration in Hans's biography changes to present tense. This change in narrative tense establishes a new temporal relationship between the two storylines, one of contemporaneity. In Hans's story this change in narrative tense reinforces the idea that the past, the old life and the old ideas Hans keeps clinging to, is gone once and for all. The break with the past is irreversible.

But there are other, even more unusual and imaginative ways in which Hensel creates a sense of disorder with her manipulation of time in Gipshut. There is, for example, the description of Hans's birth, where the narrating creates a sense of simultaneity similar to that evoked by the novel's overall structure. Considerably more unconventional, however, is the separation of story time and clock time in the Anna/Paul narrative where, for more than half of the narrative, Hensel disregards real-world standards of measuring time. Lastly, the topic of time and disorder is most noticeable in the novel's concluding pages, where the temporal structure in both narratives gradually disintegrates so that the novel's story time literally falls out of joint.

\section{Simultaneity and the Hans/Veronika Narrative}

In general, temporal structure and treatment of time in the Hans/Veronika narrative are in keeping with the tenets of realistic fiction. All of the narrative's episodes are related in chronological order, and numerous temporal expressions help the reader keep track of time passing (at least up to the Palast der Republik episode). There is, however, one instance at the beginning of the narrative, the description of Hans's 
underwater birth, where the merging of past and present action gives the same impression of simultaneity as the one that defines the novel's overall structure.

In order to take her mind off of her violent stomach pains - in reality the contractions announcing Hans's impending birth - Veronika thinks back to the memorable experience of her fun-filled ride on the forklift with Gabelstapler-Jochen. ${ }^{62}$

Der Schmerz bohrte sich vom Rücken in den Unterleib. Sie war mit ihm auf den Gabelstapler gestiegen. Wenn sie die Luft anhielt und schreiend ausstieß, verteilte sich der Schmerz auf den Körper. Jochen hatte den Richtungshebel gezogen und den Schalter gedrückt. Ein Fisch glitt unter Veronika hin. Die Fahrt war losgegangen .... Veronika spannte die Arme an, das Boot schaukelte. Sie hatte gelacht und sich die Ohren vor ihrem eigenen Kreischen zugehalten, und Jochen hatte gesagt, sie möge doch auch mal seinen Hebel berühren, und Veronika hatte nicht gewußt wie und was. Etwas warmes, flüssiges verließ sie, da wollte sie um Hilfe rufen, aber die Fische kamen und fraßen, und es ging weiter. Der Gabelstapler war surrend durch das Lager gefahren, . . . es war ein Spaß gewesen! Veronika zog die Beine an den Bauch. Das Gefährt hatte einen Haufen Säcke gerammt, der Motor war blockiert. (my emphasis, 20)

The unique effect of this scene is created by the merging of two different voices, the narrator's and Veronika's, which in turn brings together the two different realities, present and remembered action. The organizing consciousness of this passage is that of the narrating voice, but it keeps shifting back and forth between the depiction of action

\footnotetext{
${ }^{62}$ To bring out more clearly the back and forth between narration of memory and action, those sentences that tell of Veronika's memory are printed in italics.
} 
and Veronika's thoughts (marked by italics). This merging of authorial and figural narration not only allows the reader to hear two voices simultaneously - the narrator's and Veronika's - but it also has her be in two different places, participating in two different temporal realities simultaneously. Indeed, in this passage we can see the same merging of timelines, the same Nebeneinander of past and present, as in the novel's overall structure. The effect of Hensel's play with simultaneity is both comical and serious. Veronika's report of the ride on the forklift is hilarious because it is hard to believe that a young woman can be this ignorant of one of the most fundamental human acts - sexual intercourse. In other words, the humor is a direct result of Hensel's choice of voice and the resulting contrast between Veronika's ignorance and the reader's knowledge. This combination of humor and duplicity is also reflected in the language itself, in the sexual innuendos and double entendres, which add yet another layer of comic meaning to the scene. Elaborating on Hensel's play with language and voice, critic Antje Baumann remarks that the "kunstfertige Einschalten doppeldeutiger Sätze und Satzteile" plays an important role in the comic effect of the birthing scene because "[s]o ist es möglich, die markierten Sätze bzw. Teilsätze sowohl der Zeugung als auch der Geburt zuzuordnen" (128). But there is also a serious point to Hensel's light-hearted play with perspective and language. The scene has a sad undertone because Veronika's ignorance is a sign of emotional neglect and as such reflects negatively on her environment and on the society that is supposed to take care of her. The true target of Hensel's subversive humor in this passage, as Lyn Marven has pointed out, is less Veronika's naiveté than it is "the society which allows such discrepancies in power and knowledge to persist" (Body and Narrative, 194). The scene of Veronika giving birth in 
the lake, as it turns out, is more than just verbal acrobatics and clever play with narrative conventions. The duplicity both in language and in narrating points towards a fundamental problem - a disorder - in the system itself: Real existierender Sozialismus claims to be dedicated to the advancement and welfare of the country's working-class. How then is it possible that an impoverished working class orphan is left to her own devices, unprotected and uneducated $?^{63}$

\section{Parallel Worlds: the Anna/Paul Story}

In Gipshut's other narrative, which is a combination of love story, fairy tale, and adventure story about the two East German geologists Anna Fricke and Paul Norg, Hensel's play with the concept of time is first and foremost a means of reinforcing the story's fantastic quality. Anna and Paul's first afternoon by the lake, which marks the beginning of their cooperative project, is blown out of proportion in more than one sense. Though the team's adventure by the lake represents only a fraction - just a few hours - of story time in the overall temporal scheme of their narrative, the narrating of these few hours fills more than half of the total number of pages. (Approximately thirty-seven out of fifty-four pages, or fifteen out of twenty-five sections, deal with this one episode.) In addition, time itself is out of joint during these hours the pair spends at the lake: first, clock time comes to a standstill while simultaneously hours of story time go by; then,

\footnotetext{
${ }^{63}$ Hensel's criticism of society (and implicitly also of GDR socialism) is one of the main themes of Veronika's story. The young woman, though generally treated kindly, receives very little respect and is never taken seriously. Her colleagues treat her with joviality, but they also exploit her simple-mindedness for their own entertainment. No one (and especially not her son Hans, who claims to be dedicated to the socialist mission) pays attention to her emotional needs.
} 
within this surreal temporal vacuum, time suddenly speeds up as almost a year of calendar time gets condensed into just a few minutes.

Though the separation of story time and clock time represents a decisive break with the conventions of realistic narration, the narrating voice talks about the occurrence as if it were nothing out of the ordinary. After their arrival at the lake at twelve noon, the two geologists unpack their equipment, put up the tent, and get ready for their exploration of the lakeshore. When after what seems like hours of preparation, the team is finally ready to leave, the narrating agent reports that the sun is still in its zenith and that according to Paul's watch it is still "Punkt zwölf" (22). Though the characters (just like the readers) are puzzled by the contradiction between their subjective sense of time passing and what time it (supposedly) really is, they soon accept this inconsistency as part of reality. Next, page after page is filled with the description of the pair's bizarre adventures as they circle the lake, and when Anna finally returns to the campsite, but Paul is still nowhere to be seen, her state of mind is described as follows:

Langsam kehrt das Leben zurück. Wenngleich Anna keine einzige Frage nach den Vorfällen der letzten Stunden beantworten und auch die Abwesenheit des Kollegen Norg nicht erklären kann, beginnt sie doch langsam an die Wahrhaftigkeit ihres Auftrags zu glauben. (my emphasis, 111)

At first, there seems nothing unusual about the narrating voice's relating Anna's notion that she must have spent hours finding her way around the lake, especially since the description of her various adventures filled altogether eleven sections and thirty-seven pages of the narrative. A few sentences later, however, the authorial voice undermines its 
own narrating as we read, "Unverrückbar steht der Mittag über dem See. Anna schmeißt den Bunsenbrenner an, um Kaffeewasser zu erwärmen. Mit einer Stirnkappe schirmt sie die Sonne ab und wartet auf Norg" (my emphasis, 111). The clash between the time that Anna must have spent walking around the lake (the time used up by action) and the narrating authority's insistence that time stood still, is even more dramatic than earlier in the narrative. It is obvious that the text has created its own reality, one that defies the laws of nature. This self-conscious calling attention to the narrative's fictionality marks a turning point in the Anna/Paul story. With this playful shift from realistic narration to the fantastic and improbable, Hensel establishes a new frame of reference for this part of novel.

Before looking at the deeper implications of this paradoxical play with time, I want to turn to one other instance in the Siethener See episode where the narrating contains a similar splitting of temporal reality. The passage in question describes Paul's encounter with Pschespoldnitza. After Paul fails at the task of storytelling, the fairy puts him in charge of a different job. She has the exhausted man go through all the steps of making linen sheets: seeding, growing, and harvesting the flax; extracting oil from the seeds; spinning the dried stalks into yarn; and finally weaving the sheets. This process would normally take months to complete, but Paul accomplishes it in just a few hours, so the reader is told (111-114). If time was out of joint before, it is even more so at this point, as Hensel has added yet one more turn to an already twisted situation. Time is standing still, time is now also being compressed, but compression of time presupposes that the clock is moving in the first place-not to mention that stuffing months into one 
single afternoon defies the laws of nature. Irmtraud Morgner could not have thought of a more imaginative way of challenging the reader's expectation of verisimilitude in fiction.

By splitting time in such ways, Hensel creates two different realities that exist side by side. One of these worlds is a copy of the world as we know it; in the other, the laws of nature no longer apply. ${ }^{64}$ Such play with parallel worlds is one of Irmtraud Morgner's trademarks, but it can also be found in the works of other East German women writers such as Monika Maron (especially in Die Überläuferin) and Brigitte Reimann. ${ }^{65}$ Like these women, Hensel uses the fantastic in the Anna/Paul narrative to invite her reader to let go of her preconceptions, to expand her notion of what to accept as real, and thereby open herself up to new experiences and new insights. Inge Wimmers uses the term "effet de fiction" (fictionality effect) for such instances when a writer deliberately undermines the convention of referentiality. Contrary to Barthes' reality effect, the fictionality effect is meant to destroy, rather than reinforce, a text's referential illusion" (Poetics of Reading, 18). It is designed to de-stabilize the idea of verisimiltude and instead expose the narrative's inventedness.

Incorporating into her fictional world instances that violate the laws of physics, logic, or psychology — as represented here by the paradoxical splitting of narrative timeHensel destabilizes her text and emphasizes its inventedness. In order to make sense of Hensel's play with time and accept it (as well as the other seemingly nonsensical occurrences in the narrative) as true, Hensel's reader has to reconfigure her expectations

\footnotetext{
${ }^{64}$ Part of this other, fairy tale reality in the Anna/Paul narrative is also the talking plants, stones, and animals, the unseasonal climate changes, and the appearance of the Mittagsfrau Pschespoldnitza.

${ }^{65}$ This technique of creating parallel worlds through the grotesque distortion of reality is generally used by surrealist artists as a way of opening up and exploring other dimensions of reality.
} 
and adopt a more flexible, more inclusive frame of reference-one that allows for the supernatural to be part of the natural. In other words, Hensel here redefines the notion of truth in Gipshut. In her essay about Heinrich Heine’s poem “Hymnus,” Hensel briefly explains the reason behind her method of incorporating alternate realities into her fictional texts. "Die Ferne zum Alltag, also auch die zu stattfindenden Aufständen, muß nicht die Ferne zur Gesellschaft bedeuten. Im Gegenteil” ("Bin ich das Schwert? Bin ich die Flamme?" 76). This is one of the crucial aspects of Hensel's approach to writing, and one that closely links her work with that of Irmtraud Morgner. It is an aspect that runs like a red thread through all of her fictions, starting with her very first fictional text, „Katzenbericht,” to her most recent novel, Lerchenau. Hensel, like Morgner, insists that for a literary work to inspire in its readers the desire for change, it must not simply be a copy of life. On the contrary, the self-consciously invented and the unrealistically distorted elements may strike the reader as more real-more true to life-than the most carefully crafted description of surface reality. Readers of Gipshut will certainly concur. As different as Hensel's play with time in the Anna/Paul narrative may be from her manipulation of time in the description of Hans's birth, the idea of simultaneity is central to both. In the birthing scene, Hensel skillfully merges Veronika's memories of Hans's conception with the description of his birth, thus creating for the reader a new experience of time and space - the contemporaneity of past and present. In the depiction of Anna and Paul's adventures by the lake, Hensel, now redefining the concept of fictional reality, is confronting her reader once again with two parallel worlds - one that is modeled after real life and one that is self-consciously invented. This play with parallel worlds is one of the more conspicuous instances of disorder in Gipshut. Aside from being 
yet one more an example of how Hensel keeps undermining the narrative's referential illusion, these notions of simultaneity and parallel worlds quite accurately describe the unreal aspect of living in the post-Wende East. A political, economic, and social transformation of the magnitude of the one that East Germany experienced after the historical turn does not happen from one day to the next. Though some changes were immediate, many of the old established ways of life lingered on, and as they were slowly readjusting to the new situation, many East Germans felt that they lived in two worlds, were part of two realities at the same time. In a sense, finding their way in this new life must have been as much an otherworldly experience as that of Anna and Paul during their exploration at the lake. Thus, the "Ferne zum Alltag" that Hensel created in the Anna/Paul narrative is more than creative play with narrative conventions. It is a metaphor for the East German Alltag in the early 1990s.

After the Fall of the Wall: A World out of Joint

The temporal disorder of the novel's final ten sections - their falling out of timeis represented most dramatically by the sudden change from past to present tense in the Hans narrative, a move that is unusual as far as narrative conventions are concerned and that considerably changes the temporal relationship within the narrative as well its mood. On the level of the narrating, this change in tense signifies what Genette calls a temporal isotopy (Narrative Discourse, 221). It marks the moment when the story overtakes the narrating and when the two converge, thus entering a relationship of "relative contemporaneity" (220). Furthermore, according to Genette, this shift from subsequent to simultaneous narrating slightly changes the narrator's posture. It diminishes the perceived 
distance between the narrator and the action and changes his role from historian into that of a contemporary (220). But the reader, too, is affected by this shift in narrative tense as it brings her closer to feeling like a witness than a listener. This impression of credibility, authenticity, and closeness to the events described in these last sections is deceptive, however, and yet one other example of Hensel's tongue-in-cheek play with narrative conventions and readers' expectations as it is soon to be undermined by the novel's bizarre and unrealistic ending.

Another aspect of the novel's temporal disorder is the gradual disintegration of story time in both of the novel's narratives. Despite Hensel's unconventional manipulation of the novel's story time and narrative tense, the reader can easily keep up with time passing as she is making her way through the two narratives - at least until she reaches the Palast der Republik episode. With the merging of the two storylines, the temporal structure in both narratives gradually begins to crumble. Though Hensel still maintains the basic chronological order, keeping track of time becomes increasingly impossible till finally the novel drifts into a kind of timelessness typical of fairy tale endings.

In the Hans plot, this gradual falling out of time is psychologically motivated. It reflects Hans's growing disconnectedness from the world around him (a world that he no longer understands) and is marked by an increased emphasis on the representation of Hans's consciousness. Unable to cope with the monumental changes that are sweeping through his country, Hans drifts more and more into isolation. His situation is described as follows: 
Was ihn quält ist, daß er nichts mehr wissen will. Alles Interesse an jeglichem Gegenstand ist versiegt, versickert in den gewaltigen Umwälzungen der Zeit, denen er nicht folgen konnte und von denen er nichts will. Nicht einmal das einfache dahinexistierende Leben. (225)

As a result of his waning interest in the world around him, Hans withdraws into the day-by-day routine of his lonely life. Gradually losing all sense of time, he no longer knows, or cares to know, what day, month or year it is $(212,223,225)$. With his progressing physical and mental deterioration, the narrative's temporal structure, too, gradually disintegrates. Occasional temporal expressions, such as "an einem Septembertag (209),” “[p]ünktlich zu Beginn des neuen Jahres (223), or “eines Morgens (225)," though quite specific, have no meaning because they are given out of context and are missing a larger time frame. The last sections of Hans's story could have taken up weeks, months, and even as much as a year of story time. (It would have been the narrator's task to provide the missing clues, and it is significant that s/he doesn't.) This vagueness of clock and calendar time is now a reflection of Hans's emotional state and his increasing detachment from the world around him. He is suspended in a state of waiting - waiting for something to happen, though he doesn't know exactly what. Moments before Hans discovers that this something will be Anna and Paul's volcano, the narrating voice, refusing to make use of its omniscience, recaptures this sense of temporal limbo one last time. "Es ist Hansens Zeit," we are told, "Welcher Tag? Welches Jahr? Was weiß denn er?" (226). Noteworthy here is the narrator's announcement, "[e]s ist Hansens Zeit" (it is Hans's time), with which Hensel adds yet one more twist to her play with time-the substitution of clock time with historical time. 
Unlike in Hans's story, the temporal disintegration of the Anna and Paul narrative is not at all psychologically motivated and is less of a topic. Once the team detects the crater, and once they find out that their sensational discovery is not to be publicized, the Anna/Paul narrative quickly peters out. Indeed, it seems as if with the resolution of this narrative's two main conflicts - the search for the volcano and the love-story — the driving forces behind the plot are gone and the narrative changes direction. Having lost their jobs as scientists, the couple is now pursuing a goal that is real, the narrating voice reports. Working as communication experts, they are dedicating all their time to their new mission, Berlin's transformation into Germany's new and ultramodern metropolis. Only occasionally, and not without some embarrassment, do they remember the days of their chase after the volcano. Having left behind the fairy tale plot, the narrator now seems in a hurry to wrap things up. Indeed, the last three sections of Anna and Paul's story are just three short paragraphs that, together, cover only two pages of text and culminate in an equally hurried conclusion.

Der Eröffnungsempfang für den Senat steht bevor, eine internationale Pressekonferenz, ein Regierungsball, eine Bauherrensitzung und, im Alabastersaal, eine Parteiensondertagung mit Fernseh-Liveübertragung. Paul und Anna sind zuständig. Dafür und für alles andere, was anfällt. Und was ihnen zufällt: Aufträge, Anfragen, Presseartikel, Posteingänge, Zeitnot und manchmal, in einer minutenlangen Pause, ein Stück Liebeslust. Sie schließen dann das Büro ab, und, mit Blick durch das Fenster auf den Lustgarten, bauen sie einander auf in der hydraulichen Federung des Schreibtischstuhls. (224) 
In telegram style and with a few sweeping strokes the narrating voice here sums up weeks and months of action - how many exactly, we don't know. The telling is hurried and brisk - lists, short phrases, and no descriptive detail - just as Anna and Paul's new life is hectic and packed with an endless list of commitments. ${ }^{66}$ Only their lovemaking is a reminder of their old life, but being squeezed into the tight schedule of their daily activities, its romance is gone.

As Gipshut's two narratives come to a close, all three characters seem to be drifting in some kind of surreal time warp though they do so in different ways and for different reasons. For Hans, time has lost all meaning. Since his world disappeared virtually over night, he now spends his days in limbo, waiting for some dramatic change. ${ }^{67}$ For Anna and Paul, on the other hand, who are chasing after the dream of a new and better future, time seems to be running away, passing so fast that they can barely keep up. In their busy life, there is no time to take time or keep track of time passing. At the very end of the novel, then, it is indeed Hans's time. By keeping his discovery quiet and letting the volcano (or was it perhaps just a defective gas pipe?) blow up, he is finally making history. As with everything Hans ever attempted, his final hurrah is not a heroic act but just one more proof of his grotesqueness and his warped character. With the

\footnotetext{
${ }^{66}$ These last three sections of the Anna/Paul narrative are the weakest part of the novel. Jill Twark calls them anticlimactic and farcical. True, the sudden transformation of the Anna/Hans story into a satire about the rebuilding and reshaping of Berlin seems unmotivated and like a cop-out ending. The shift in focus is too sudden and too undeveloped in order to be convincing. At the same time, however, these sections are also simply a continuation of the anti-mimetic, illogical, and grotesque kind of storytelling that is the novel's defining characteristic.

${ }^{67}$ This notion of Hans being stuck in the past is also symbolized by his new job, which as mentioned earlier, consists of moving around and stacking plaster replicas of the heads of historical figures. The stuffy basement of the Stadtschloss, surrounded by the images of those who once made history (which is of course also Hans's dream), is where he now feels most at home.
} 
volcanic eruption, the narrative takes on a mythical dimension since the fire and ashes that cover the city now come to signify the supervening of cosmic time.

Hensel's unconventional and imaginative ways of dealing with the concept of time in the novel's two narratives is one of the work's unique aspects and it is emblematic of a phenomenon that is distinctive to East Germany and countries behind the iron curtain. With the Fall of the Wall came a sense of historical displacement, and the speed of the change created strange kind of time warp.

\section{Narrating and the Construction of Gegenwelten in Gipshut}

A central feature of Hensel's transgressive kind of narrating in Gipshut is her ironic play with such elements as narrating voice, focalization, and narrative tense. Together, they further the sense of disorder in the novel's fictional world and they are important for establishing the novel's meaning. As implied by her comments about her role as writer, decisions concerning a particular story's angle of vision are influenced for Hensel not only by formal and aesthetic concerns but also by moral ones. Though both of the novel's stories seem to be related by the same narrator - an undramatized, seemingly objective observer/storyteller-there are some decisive differences in the telling of each story. To describe these differences, explain how they destabilize the novel's fictional world, and elaborate on their effect on the work's meaning is the purpose of this section. I will begin with a few general remarks about the novel's narrator and Hensel's narrating. The major part of this section, however, will be dedicated to a comparative analysis of Hensel's use of voice, focalization, and narrative tense in the novel's two narratives and a brief description of how they affect the work's meaning. 
The one important commonality between the novel's two narratives is that in both cases the narrating plays an important role in establishing the sense of dissonance and disorder. This Hensel achieves not by intrusive authorial commentary but by exploiting different forms of mediation with which she invites the reader to read between the lines. Subtle changes within as well as between the narrating of these three stories, such the withholding of important information, levels of figural narration, and types of discourse determines the effect of a particular scene-whether it is merely comical, slightly critical, perhaps, or ironic, or whether it is to be understood as parody or even biting satire. In the Hans/Veronika narrative Hensel's play with voice and focalization are first of all meant to expose Hans's misguidedness. They reflect Hensel's critique of the GDR's political system but they are also meant to expose the dangers of self-centered, compulsiveobsessive behavior in general. In the Anna/Paul narrative, the narrating is defined first of all by the storyteller's humorous undermining of conventional notions concerning the idea of referentiality. Exposing the text's fictionality serves as a reminder that, though filled with numerous moral and philosophical truths, Gipshut is first of all a work of art.

\section{Gipshut's Narrating agent: A Brief Characterization}

After her experiment with first-person narration in Tanz am Kanal, Hensel returns in Gipshut to the kind of detached, all-knowing narrator/storyteller from her earlier short stories and her first longer fictional work, Auditorium Panoptikum. The anonymous voice that in a nonchalantly calm and detached manner tells about even the most tragic, bizarre, and other-wordly events is the one commonality in Gipshut's two narratives, and it is arguably also the most interesting aspect of the novel. 
With the detached look of a camera eye, the novel's narrating agent moves in and out of the characters' minds, reporting facts and thoughts with often disquieting equanimity. It never relinquishes its even-tempered, factual pose and never offers any judgment, commentary, or explanation. At the same time, however, it carefully chooses what to tell, when to tell it, and how much to tell so that the reader can always feel the presence of this mediating consciousness called the novel's narrator. Proof for such selective narrating is abundant and will be discussed in more detail later, but here are a few of the more obvious examples. For instance, the novel's elaborate structure with the creative intertwining of the two narratives, the obviously constructed conclusion, and certainly the tongue-in-cheek "Ende" with which the voice ends its storytelling are all indications of the narrating agent's rigid control over its material.

Hensel's narrating agent poses as a detached, objective reporter of thought and action while never revealing its own thoughts and opinions. Though all-knowing, it is quite selective with the information it passes on to the reader. At the beginning of Veronika's story, for example, the reader is never told explicitly the reason for Veronika's weight gain or her uncontrollable hunger.

One other noteworthy characteristic of Hensel's narrating is her frequent use of paralipsis. Sometimes, the reader is overwhelmed by the narrating agent's pedantic concern with detail; other times, however, when the reader wishes for some important information about the characters' lives, the voice's silence is annoying. As a result, many times throughout the novel, the reader is left with cognitive gaps and it is up to her to read between the lines and fill the void. For example, at the very beginning of the novel, the narrating agent paints a very realistic and detailed picture of Veronika riding her 
bicycle to the Siethener See. The description of the heather's scorched vegetation, of landmarks such as the old bomb crater, and of other peculiarities of the region's geography is as precise and vivid as a photograph, but one important piece of detail is not mentioned-Veronika's pregnancy. By deciding to have all information about Veronika delivered not by the omniscient narrator but by Veronika herself (i.e., in the form of figural rather than authorial narration), Hensel has the reader partake in Veronika's ignorance. But as explained earlier, focusing on Veronika's thoughts becomes a source of ironic humor. It allows the reader to use her superior knowledge and thus makes Veronika's naïveté seem even more shocking. (The hypothetical reader must not be an expert in literary analysis to recognize the meaning of such symptoms as sudden weight gain, the strange craving for salted foods, and recurrent, wavelike pain in a woman's lower abdomen.) Such absence of authorial commentary when it would be expected-a narrative move that is not just limited to the telling of Veronika's story - not only engages the reader directly in the making of meaning, but also emphasizes the everpresent clash between the characters' and the narrator's world as well as between that of the characters and the reader. Especially in the case of Veronika's story, as I will explain in more detail later, the narrating agent's silence exposes the young woman's ignorance and naiveté. Whereas in the earlier parts of Veronika's story, the authorial silence is the source of comic humor, later it is essential for establishing the story's dramatic irony.

This almost paradoxical discrepancy between the narrating agent's omniscience on the one hand, and the refusal to let the reader partake in its superior knowledge on the other, is the direct result of Hensel's ironic play with focalization-of the way in which sustained inside views of the narrative's characters alternate with passages when the 
narrating voice relates events directly, either as scene or summary. Hensel's sophisticated handling of focalization - the carefully orchestrated back and forth between different angles of perception, between authorial and figural narration, is the most important aspect of Hensel's narrative method, her primary tool for controlling the reader's response. As Hensel's narrator moves freely in and out of the characters' minds, the shifting from external to internal focalization - from detached, objective reporting to words and phrases that reflect the character's consciousness - is often so subtle that it is not always possible to determine in the case of every sentence whether focalization is external or internal. The following passage, taken from the beginning of Veronika's story, shows this kind of crossing back and forth between objective reporting, quoted monologue, and narrated monologue.

Sie hatte viel gegessen in letzter Zeit und daher ordentlich im Fleisch zugelegt, zu viel vielleicht, dachte sie. Dann kam der Zeitpunkt, wo es sie nach Fisch gelüstete. Schon seit Monaten überkam sie regelmäßig diese Sucht nach Havelländer Fisch. . . . Kein Lüftchen ging. Alles still hier. Veronika Dankschön setzte sich auf den Bootsrand ....

The first sentence has the markings of narrated monologue as indicated by the speech tag, "dachte sie," while the "Alles [ist] still hier," later in the passage, is quoted, i.e., interior monologue, now marked by the shift to present tense implied by the "hier." The second and fourth sentences are unmarked and thus could be read as instances of objective reporting if it were not for the words "schon" and "diese" in the third sentence. These words indicate that the narrating represents Veronika's perspective rather than the narrating agent's, which makes them examples of narrated thought. Only the very last 
sentence of the passage unambiguously represents objective narrating while the brief interjection, "Kein Lüftchen ging," could be both, a continuation of Veronika's narrated thought or a simple reporting of fact. Such mixing of external and internal, of aperspectival and perspectival presentation, is of primary significance for the dissonant narrating and the resulting construction of the novel's Gegenwelten.

Then there are instances when Hensel's narrating agent tells us what is transpiring in the protagonist's mind but where even the description of the outer world becomes a reflection of the protagonist's inner world. Franz Stanzel calls this type of narrating “experienced description" (A Theory of Narrative, 74/77) ${ }^{68}$ As can be seen in the following excerpt taken from Veronika's story, while the language is that of the authorial narrator, the description itself represents Veronika's subjective experience of the particular scene.

Trotz der Schmerzen, die in dumpfes Drücken übergegangen waren, fühlte sie sich gut. Eine Natter schlängelte vorüber, den Kopf kielartig über dem Wasser. Veronika strampelte, das Tier zu vertreiben. Libellen, welche im Tandemflug hin und her schwirrten, um schließlich, am Bootsrand festgeklammert, in ihrer Paarungsschleife zu verharren, sah Veronika Dankschön voller kindlicher Freude. Wie lange sie sich schon im Wasser des Sees mit der Natur verbündete, hatte sie nicht im Gefühl. Gleichgültig alle Zeit. Es war Sonntag. (9)

The language of this passage is too poetic and too literate to be Veronika's, but the idyll that is being described is clearly a mirror of Veronika's state of mind. The scene reflects

\footnotetext{
${ }^{68}$ In the case of experienced description, Stanzel explains, the description takes on metonymic importance as it reveals certain states of the hero's consciousness (74).
} 
the young woman's childlike notion of nature as a kind of locus amoenus, a paradisiacal refuge. Whereas before, Veronika's ignorance was merely comical and amusing, in the passage above, the incongruity between how Veronika sees the world and how things really are is much more pronounced than before and gives the passage an ironic twist. The inflated and self-consciously lyrical language with its ring of artificiality exposes the folly of Veronika's childlike idealizing of nature and thus reinforces the dramatic irony of the scene. While Veronika is still mystified by the workings of her body, the reader, knowing what is about to happen, can indulge in her superior knowledge. Had these impressions been delivered in the plain, unsophisticated language of Veronika's speech (as narrated monologue, for example), the incongruity of the scene would have been less striking.

Already in the novel's first few pages, as my examples have shown, Hensel finds ways to make the narrative say more than it says by manipulating mood and voice. By selectively using various levels of figural narration while never compromising the narrating agent's detachment, Hensel has created a fictional world where things are not quite what they are made out to be. Her play with focalization brings out even more sharply the characters' blindness and the futility of their strivings and heightens the sense of irony that pervades all aspects of the novel's fictional world.

Central to the construction of Gipshut's subtext (evoked by various dissonances between voice and mood) are the subtle changes in the telling, depending on whose story is being related. One way in which Hensel orchestrates the emergence of the different Gegenwelten is through sudden shifts in focalization and through the selective use of authorial omniscience. In the remaining part of this section, I shall identify some of the 
major dissonances created by the frequent shifts in focalization and describe their effect on both the meaning and tone of each narrative. In the Veronika/Hans narrative, dissonance is first of all a result of the clash in knowledge and value systems between narrator, (implied) reader, and characters. The sense of disorder created by this dissonance exposes the fallacies and moral as well as political failures of East Germany's former political system, real existierender Socialismus. In Anna and Paul's story, in contrast, the dissonance is an effect of Hensel's ironic subverting of narrative conventions, and it now serves a different purpose than in the other narrative. By repeatedly undermining the laws of realistic narration and thereby foregrounding the text's fictionality, Hensel lays bare and simultaneously mocks the false hopes and unrealistic expectations of people in the post-Wende East.

\section{Two GDR Biographies}

Though in both biographies the dissonance in the narrating is designed to lay bare the failures and grotesque incongruities of real existierendm Sozialismus, there are some subtle but decisive differences in the narrating of Hans's and Veronika's story.

In the narrating of Veronika's short and unhappy life, the key idea behind the dissonance is Veronika's naiveté and simple-mindedness. These characteristics get exploited first and foremost through the skillful manipulation of figural and authorial narration. Hensel's narrator never actually tells about or directly comments on Veronika's mental handicap, on her childlike nature, her inarticulateness, and her general lack of understanding concerning her own feelings and those of others. It is by allowing the reader to see the world through Veronika's eyes - sometimes directly in the form of 
narrated or quoted monologue and sometimes indirectly, through psycho-narration - that Hensel reveals Veronika's limitations.

Especially at the beginning of Veronika's story, the emphasis on figural presentation, the narrating and quoting of Veronika's bewildered thoughts combined with the total lack of commentary is comical and entertaining. The reader cannot help but laugh at the girl's naiveté despite the fact that such a degree of ignorance is sadly tragic. As the story progresses, Veronika's life becomes increasingly unhappy, but through her skillful manipulation of focalization, Hensel purges emotionally charged scenes of their disturbing content, thus making them less poignant, as reflected in the following example.

In order to deal with her loneliness, Veronika often passes the night singing romantic songs. Though young Hans is bothered by his mother's "Katzengejaule," Veronika refuses to listen to his complaints. “Aber Veronika sang, hörte nicht auf den Jungen, ignorierte seinen Protest," the authorial voice reports and then continues to explain,

denn seit sie Jochen nur noch auf dem Gabelstabler im Lager der Konsumgenossenschaft begegnete, mußte sie etwas gegen die Stille im Haus tun. Hans war ja fast immer schweigsam, so viel mit Papier und Büchern beschäftigt, ganz und gar fremd. (51) Rather than elaborating on Veronika's feelings, the narrating agent simply relates the circumstances that caused her strange habit. Even the sentence of narrated monologue, "Hans war ja fast immer schweigsam, . . ., ganz und gar fremd," sounds strangely detached because of its factual tone, and if it were not for the interjected "ja," the 
sentence could be read as pure narration. While the narrating agent refrains from elaborating on Veronika's inner life, her monologue shows that Veronika lacks the ability to reflect upon her feelings or even acknowledge them. Hensel's technique deserves some closer attention. Not only does the narrating voice show no empathy for Veronika's situation, as revealed by its detached and factual language, but Hensel also refuses to make full use of the narrator's omniscience. While Veronika is unable to describe her inner turmoil, Hensel could have had the narrator step in and elaborate on her emotional life. The incongruity resulting from this emphatic insistence on distance is the essence of Hensel's dissonant narrating, of a narrating which leaves the important things unsaid. Ultimately, and as further supported by my next example, the point is not really Veronika's psychology. The point is the dissonance evoked by such narrating.

Nowhere is this clash between narrating and narrated, between language and context, more pronounced and more disturbing than in the description of Veronika's suicide. Here, the dispassionate tone glosses over the tragedy of the event and thereby transforms Veronika's suicide into something grotesquely absurd.

Als die Pschespoldnitza die Wohnung verlassen hatte, ging [Veronika] ins Schlafzimmer. Aus dem unteren Fach des Wäscheschrankes, . . , nahm sie die Kabelrolle aus buntem Bakelit. Noch immer mußte Veronika lachen, dieser Fluß [i.e., the flow of her laughter] war nicht abzustellen, . . .. Sie zog das Kabel aus der Gehäuseöffnung und rollte es bis zum Ende auf. Schwarz und nach Gummi riechend, lag es in ihren Händen. Jochen hatte es nie benutzt. Auch Hans konnte es nicht gebrauchen. Es war noch 
ganz neu. Dann suchte sich Veronika eine passende Stelle. (my emphasis, $179 / 180)$

During most of this scene, Hensel uses external focalization, relating the situation from the vantage point of a camera-eye that is merely recording Veronika's every move. The tone is cool and factual, and as in the previous example, the narrator provides no information about the woman's emotional state. Indeed, there is a certain eeriness to the business-like, matter-of-fact manner of the reporting. Not just incongruous but grotesquely absurd is the lack emotional content in Veronika's thoughts (the sentences are set off by italics). In fact, the merging of the narrator's voice with that of Veronika's in the few sentences of narrated monologue deserves closer attention. Though the sentences once again display Veronika's inability to acknowledge her feelings, there is also a deeper significance to her words. The cable - Veronika's unsuccessful Christmas present for Jochen - is a representation of Veronika's sense of isolation and uselessness. Ultimately, then, the lack of emotional language in the narrating and the specific nature of Veronika's thoughts bring out more poignantly than any authorial commentary the quiet tragedy of the woman's life, a tragedy that is heightened by what is perhaps the most provocative understatement in all of Gipshut, "Dann suchte sich Veronika eine passende Stelle." In this scene the use of ellipsis exacerbates the overall sense of incongruity in Veronika's story and further emphasizes the disproportion between the telling and the told. With her selective silence, Hensel carefully directs the reader's attention to another kind of truth, one that is revealed by what is left unsaid.

To sum up, several points can to be made about the narrating of Veronika's biography. First of all, the detached and factual language of its telling prevents the reader 
from getting emotionally involved in story of Veronika's life and thus keeps the story from deteriorating into melodrama. In fact, in the final sections, the absence of emotional language gives Veronika's actions a certain dignity. Secondly, as her story progresses, the detached manner of reporting brings to the fore the inherent irony in Veronika's life and makes her story become grotesquely unreal. The indifference, the understatement, and the trivializing in the narrating turn her biography into a parody of the working class heroine. But more importantly, the Gegenwelt created by the story's narrating lays bare the lie of real existierendem Sozialismus and reveals its most tragic failure-to secure the happiness and progress of the country's working class.

If Veronika lacks the ability to understand the ways of the world and reflect upon her life, Hans, on the other hand, spends too much time dreaming up various grand plans for his own life and for the future of mankind. Though not too smart, Veronika is a pragmatist and a doer. Hans, in contrast, is a coward. He can talk a good game, but fails miserably when it comes to backing up his words with action. These differences in the two characters' personalities are also reflected in the narrating of the two stories. Not only does Veronika's biography contain little narrated and quoted monologue, but also, as described above, her monologues are conspicuously devoid of reflection. Hans's story, in contrast, abounds with narrated and quoted monologues. The constant switching back and forth between authorial and figural narration brings about a blending of perceptions and voices, which exposes the delusiveness of Hans's thinking. Even more than in Veronika's biography, the narrator's stance as objective observer and the absence of any evaluative remarks, no matter how misguided Hans's ideas or how bizarre his actions, is essential to the construction of the story's Gegenwelt. Through dissonance evoked by the 
authorial silence Hensel reveals the underlying disorder in Hans's story. It is thus the narrating itself and not the storyteller's intruding commentary that reveals the grotesqueness of Hans's character and that gradually transforms the man's story into a satire on the GDR and its political system. Hensel's construction of Gegenwelten thus serves several purposes: Aside from being fundamental to Hensel's critique of the GDR's political system, it also is a means of exposing the destructive nature of Hans's selfcentered and obsessive behavior, and finally, it is also the main source of the narrative's ironic humor and satire.

Hans's story abounds with examples of the fundamental incongruity between Hans's world and that of the narrator and implied reader. I shall limit myself to just a few passages with which to explain in more detail some of the specific features of Hensel's narrating. The first passage shows Hensel's method of creating dissonance by a particular blending of perceptions and voices. Having just found out that he is accepted as a journalism student at the university in Leipzig, Hans is certain that he is destined to make an impact on mankind's future. His enthusiasm about his new life is described as follows. Im Bus nach Nudow sah Hans Kielkropf die Landschaft nun anders. Satter und grüner die Kiefern- und Erlenwälder. Fetter die Kartoffelfelder. Silos und Viehställe als Bauwerke des Fortschritts. Die Seen waren Perlen der Heimat und die grauen Dörfer mit ihren moosigen Schindeldächern Horte der Zukunft. Ein Stück Geschichte hatte er bereits mitgeschrieben. Er war der tätige Kern des historischen Augenblicks. Er würde Bericht erstatten über alles und durch seine Berichte ändern, das alte zum Fortschritt 
führen, in immer höhere Qualität; Volkswirschaftspläne würde er mitbestimmen, . . ., und der Bus ruckelte die Landstraße entlang. (74)

The first sentence is delivered by the authorial narrator and sets the scene for what is to come. In the next four sentences, a gradual inward movement begins as indicated by the shift from "experienced description" to narrated monologue. At first, the voice is still that of the narrating agent, but the description is already colored by Hans's perception. The expressions "satter" and "fetter" and the phrases "Perlen der Heimat," "Bauwerke des Fortschritts," and "Horte der Zukunft" belong to Hans's lingo, not the narrator's, and they carry the mark of the young man's (misguided) enthusiasm for the socialist state's glorious future. Starting with "Ein Stück Geschichte," the voice becomes Hans's voice. His plans for how he could be important for the country's political future are delivered in narrated monologue. This shift to a more immediate presentation of the man's thoughts, rather than bringing the reader closer to Hans's inner life, only emphasizes the utter foolishness of Hans's dreams. Ignoring Hans's foolish ideas, the narrating agent then simply continues its factual reporting, "und der Bus ruckelte die Landstraße entlang." Through this combination of psycho-narration and narrated monologue, the narrator brings to the fore the ridiculous nature of Hans's plans. Coming from the narrator, Hans's words sound out of place, incongruous, and pompous. The dissonance in the narrating dramatizes the difference in perspective between Hans and the narrating agent (and also the implied reader) and thereby makes a travesty out of Hans's dreams of bettering the world.

Especially the scenes between Hans and Paul, abound in situational irony, which is then further exploited in Hensel's manipulation of authorial and figural narrating. As 
mentioned earlier, one such instance is the episode of Paul's Eingipsung, to which I will now return in order to show how the narrating itself contributes to its comedy and satire. Nowhere is the clash between what happens and Hans's interpretation of the situation more dramatic than in this scene. Much of the scene's humor is clearly situational and a result of the stark discrepancy between Hans's idealization of the young Paul on the one hand and the boy Paul's humiliation by the nurses and Hans's failure to intervene on the other. Through the mixing of voices in the narrating, slapstick humor is quickly transformed into sarcastic mocking.

Der Gipsstiefel war angepasst. Kielkropf beschrieb, was er beim Anblick des Vorgangs empfunden hatte: Formgebung. Es war nichts Geringeres als das Gefühl: in diesem Moment wird festgehalten was in geradem, fehlerlosen Maß die Zukunft bestimmt. (157)

As before, the authorial voice's terse language sets the scene. In the second sentence, the clause "Kielkropf beschrieb" and the colon at the end of the sentence announce the impending shift from reportorial narration to the representation of Hans's consciousness. "Formgebung" is a direct quotation of Hans's thought, which is immediately followed by a sentence of psycho-narration where the evaluative comment "nichts Geringeres" (clearly representing Hans's reading of the situation and not the narrator's) makes a mockery out of the narrated monologue that follows, "In diesem Moment wird festgehalten ...." The colon after "Gefühl" plus the shift from past to present tense in the next sentence announce the shift from narration to thought quotation. The irony in Hans's assessment of the misshapen Paul as flawless and perfect is further exaggerated by the phrase "nichts Geringeres." Though already in themselves proof of Hans's blindness, the 
fact that these words are spoken by the narrating agent makes them seem even more out of place because the authorial narrator, while a truthful reporter of what happens, clearly does not share Hans's perspective. By not presenting these words in some form of Hans's monologue but instead attributing them to the narrator, Hensel not only intensifies the mocking of Hans's misguided idealism, but she also deepens the dissonance between the two viewpoints, Hans's and the narrator's.

Occasionally, rather than have the text itself be a representation of the clash between the two worlds, the narrator's and Hans's, Hensel has the narrating agent describe and also evaluate the extent of Hans's delusions. The first therapeutic session with the then three-year-old Paul, for example, is delivered predominantly (though not exclusively) from a non-figural perspective. Once again it is Hensel's particular way of mixing authorial and figural perspectives that shows the irony of Hans's thoughts and calls attention to the text's dissonance. The scene begins with a brief description of Paul's awkward and misshapen body and his helplessness, presented by the authorial narrator, and then continues as follows,

... da wußte Hans Kielkropf: Das ist mein Mensch! Zwar war Paul Norg noch ein Kind, aber aus seinem Wesen sprach schon die ganze Zuversicht des zukünftigen Menschen. Hans war begeistert. (123)

The one sentence of quoted thought is strategically highly effective because it so poignantly contrasts with what has just been described. The change to narrated monologue in the next sentence serves two purposes. While maintaining the figural perspective, it also functions as a transition between the quoted thought and the detached authorial perspective in the remaining part of the description. (It is like a gradual 
zooming out of Hans's mind.) Aside from one more very brief shift to a sentence of narrated monologue towards the end of the scene, the event is told exclusively from the perspective of the detached narrator whose words, however, clearly reflect disparagement. For example, there is the mention of Hans's "selbstlaufende, sinnlose Fragen" which Hans had spun from his readings and "die nichts und niemanden meinten." The man simply "stopfte die Worte in das Kind hinein," the narrator reports, not for the child to understand but only to repeat them to himself (123). For a moment, the narrating agent casts aside neutrality and detachment as its language communicates mocking criticism of Hans's behavior. Passages like this let even the not-so-perceptive reader see the clash in worldviews.

But it is not just Hans's delusive thinking and his utter blindness towards reality that is exposed through the ever-present dissonance in the narrating. The true target of Hensel's mocking is the political system responsible for producing people like Hans. Hans's mindless parroting of political jargon and the many instances of situational irony combined with Hensel's technique of shifting between authorial and figural narration keep exposing the failings of real existierendem Sozialismus.

Hensel's political satire becomes particularly biting after the collapse of the country's political system. Now more than ever, Hans's language sounds out of place, and his unrelenting belief in human progress, even when he is confronted with the obvious futility of his strivings, is implicitly also a ridiculing of the GDR's political doctrine.

The Wall has fallen. Having lost his job as journalist, Hans is now working inside the Palast der Republik where he is tearing down layers of toxic asbestos insulation from 
the building's interior. The parabolic nature of this scene is obvious. The Palast's asbestos pollution represents the poison at the center of the country's former government; the new East must be purged of this contamination. That Hans, of all people, is the one to perform this task is no surprise, considering Hensel's penchant for ironic twists. But as usual, Hans has his own way of interpreting the situation. He sees himself as engaged in the re-building of a new and better socialist regime.

Bei jedem Schlag, bei jedem knirschenden Ausreißen des alten Materials, sieht Hans das Neue vor sich: es ist sein Ort, der wieder hergerichtet und freigegeben wird für einen neuen Versuch des menschlichen Fortschritts. Obwohl Hansens Träume sehr wohl die gegenwärtigen Verhältnisse bedenken und er weiß, daß nichts werden wird, wie es war, obgleich ihm von Tag zu Tag das Atmen schwerer fällt und er graufasrig abhustet, geht er mit dem Feuer der Schaffenskraft an das Aufbauwerk seines Lebens. (my emphasis, 208)

Like most of the crucial scenes in Hans's story, the narrating of this passage consists of a back and forth between authorial and figural narration. The italicized parts represent Hans's viewpoint, but his subjective perspective is counterbalanced, indeed put into question, by the narrator's factual statements. Now that a new era has begun for East Germany, Hans's ideological blabber sounds absurdly meaningless. Rhetorically, Hans's being out of place is stressed both by the situational irony and by the language itself. Having the narrator, at the end of the quotation, use the empty jargon of real existierendem Sozialismus to describe Hans's unrelenting dedication turns the scene into a farce. The dissonance created by the narrating agent's use of Hans's language 
dramatizes the fallacy of Hans's thinking and draws attention to the meaninglessness of the ideas expressed in this language.

Having Hans's deluded ideas presented as quoted monologue conveys a sense of immediacy and thus emphasizes the dramatic irony of the situation. It underscores the clash between Hans's romanticizing interpretation of what in reality symbolizes the deathblow to a sick and corrupt political system. The long sentence following Hans's monologue is an instance of psycho-narration. The authorial narrator reports some of the ambivalence Hans has been feeling but refuses to admit. The shift to narrated monologue virtually in mid-sentence (the words marked by italics are clearly Hans's and not the narrator's) means a return to Hans's warped perception and emphasizes the irony of the situation by laying bare the severity of his delusions. By relentlessly exposing Hans's gullibility and the absurdity of his goals and beliefs, Hensel does more than just poke fun at the GDR phenomenon of the Mitläufer; she is writing political satire.

To conclude, Hensel's technique of dissonant narration in the Hans/Veronika narrative plays a pivotal role in the creation of the narrative's Gegenwelten and in establishing the narrative's ironic-satirical tone. The dissonance is first of all the result of the way Hensel orchestrates authorial and figural narration. Rather than having her narrator comment on the various wrongs displayed in the two stories, Hensel uses different levels of figural narration - ranging from psycho-narration to narrated and quoted monologue - to reveal the disorder in the two characters' lives and in GDR society in general. Posing as an objective reporter of thought and action, the narrating agent not only ignores but, especially in the case of Veronika's story, also glosses over the dysfunctional nature of GDR society. It is the voice's silence, its pretense that there is 
nothing unusual about the world it portrays, which creates the narrative's intrinsic dissonance and thereby makes the reader aware of another reality - a Gegenwelt-in which the reader is confronted with what Frauke Meyer-Gosau calls the "Wahnwitz" (27) and the "Gesamtwahnsinn" (34) of the novel's fictional world.

\section{A German-German Fairytale}

Though Anna and Paul's narrative is different in kind, Hensel's strategies of narrating serve the same purpose as those in the Hans/Veronika narrative - to take the reader into a world that is intrinsically chaotic. The most obvious difference is the apparent fictionality of the two geologists' story. The stories of Veronika and Hans abound in bizarre and grotesquely distorted scenes, but Hensel's narrative method, although quite idiosyncratic, is in keeping with the conventions of realistic narration - not to mention that there is a certain amount of historical truth to the two protagonists' biographies. There is no historical truth to Anna and Paul's story, however, though the issues Hensel touches upon in this narrative are based on the one of the major historical events of post-World War II Germany, the country's reunification in 1990. Theirs is a combination of fairytale, love story, and adventure saga in which Hensel purposely and playfully subverts the reader's expectation of realistic narration. The different ways in which Hensel undermines narrative conventions - her play with time, the inclusion of various fairytale motives, and the so obviously contrived plot-are essential components of Hensel's method of dissonant narrating in the novel's other narrative.

The dissonance in the Anna/Paul narrative is of a decisively different kind than that in the Hans/Veronika narrative, but I shall continue to use the term primarily as a 
metaphor for the novel's overall effect. In the Siethener See sections of the Anna/Paul narrative, dissonance is the result the fictional world's division into two parallel realities - one that is a copy of the world we know and one where the laws of nature are turned upside down. This clash is then further reinforced by the authoritative voice with which the narrating agent matter-of-factly talks about that which is not real. The characters, too, are part of this divided world. Though at first puzzled by the various strange, otherworldly occurrences, they soon treat these paranormal phenomena as part of everyday experience. With such an open display of the text's fictionality, Hensel is not only flaunting the novel's constructedness, but also reminding her reader that what is to be considered real in a fictional narrative is a matter of convention only. In the Hans/Veronika narrative, dissonance is an essential tool for revealing the underlying tensions between how things are and how they should be, and for showing what is fundamentally wrong in the characters' world. The Gegenwelt in the Anna/Paul narrative, in contrast, which is created by changing the frame of reference concerning what is to be considered real, is not so much the opposite of our world; it is a richer, more inclusive version of it. As before, the main idea is to destabilize the text and the fictional world, but it is now primarily narrative conventions that get destabilized rather than moral (and also political) norms and values.

I have already mentioned some of the major ways in which Hensel challenges the idea of referentiality in fiction. I will now focus on a few other aspects of her dissonant narrating and the construction of Gegenwelten. So far, I have been talking about the idea of dissonant narrating only as a phenomenon within each individual narrative, but there is also a dissonance between the two narratives. One aspect of this dissonance is how the 
above-mentioned realistic method of narrating in Hans's and Veronika's stories clashes with the obviously invented passages in the recounting of the geologists' adventure. The other feature that contributes to the dissonance between the two narratives is the difference in narrative tense (Erzählzeit). I have already pointed out how the difference in narrative tense undermines the novel's unity, but there are also other, more subtle, effects. It is ironic that the narrative that so clearly flaunts its ficionality is told in a tense that generally signifies immediacy and authenticity. Hensel's choice of present tense serves as a means of emphasizing the unrealistic nature of Anna and Paul's quest: the goals they are pursuing are merely products of their misguided belief in a better future. In addition to the change in narrative tense in the Anna and Paul narrative, the stress is clearly on the representation of action - on telling a good story - whereas, especially in Hans's story, providing insight into Hans's consciousness in order to illustrate the man's warped thinking is at least as important as the description of his (equally absurd) actions. This difference in emphasis is reflected also in the narrating. Most of Anna and Paul's story is presented from the perspective of the detached, omniscient narrator/storyteller, who as before refrains from any commentary. Conflict is now presented in the form of dialogue as well as through figural narration. In the following scene, for example, it is not authorial commentary but the quick change from dialogue to figural narration (in this case, the sudden, unmarked insertion of quoted monologue) that reveals the friction between the two scientists and creates the scene's ironic humor.

"Es gibt Füchse", sagt Anna. 
Norg lacht. Natürlich Füchse. Füchse ist absolut korrekt. Gegen Füchse in der Gegend ist nicht das geringste einzuwenden.

"Ein weißer Fuchs", sagt Anna, ... (my emphasis, 18)

The abrupt shift from outer to inner, from dialogue and pure narration - "Norg lacht"- to Paul's quoted monologue set off by italics, smoothly blends into the characters' dialogue. Then there are instances such as the passage quoted below, where the quick change between different perspectives, the narrator's, Paul's, and Anna's, results in a unique kind of layering. Again, the passage is taken from the earlier parts of the narrative when Anna, resenting what she considers Paul's patronizing, is still trying to assert her authority. The narrating goes as follows:

Norg macht den Vorschlag zu einem erfrischendem Bad: auch er fühle sich etwas gestreßt, und der Siethener See wäre, wenn nicht von alpiner Klarheit, so doch von solch trüber Natürlichkeit, daß er dem menschlichen Körper mit seinen reinen Schweb- und Schlickstoffen geradezu Energie übertrüge. Als Beweis dafür wirft Norg Hemd und Hose ab, .... [Anna] winkt dem Schwimmer vom Ufer aus zu. Wenn er sie jetzt ins Wasser bitten würde, würde sie Kopfweh markieren. Unverschämt, wie er, den nackten Hintern zeigend, plätschert! Vom Rückenkraul ganz zu schweigen! (19)

After setting the scene with its usual detached and matter-of-fact like reporting ("Norg macht den Vorschlag zu einem erfrischendem Bad"), the narrating agent delivers Paul's invitation to go for a swim not in direct but in indirect speech - a strategy which calls the reader's attention to the literary quality of the text. The focus then shifts back to the 
narrating agent and a longish passage of pure reporting of action with Paul still being the center of attention. To report Anna's reaction to Paul's unabashed skinny dipping, Hensel promptly switches to figural narration - first a sentence of narrated monologue in which we can hear Anna's hypothesizing about what might happen next and then two sentences of quoted monologue as a direct representation of Anna's indignation about Paul's relaxed attitude. As happens so frequently in the narrating of Veronika's and Hans's story, here too, the quoted monologue emphatically reveals the sense of dissonance. On the one hand, we have Anna who, overly sensitive to issues of gender equality, disapproves of Paul's impertinent behavior; there is Paul who, aware his colleague's sensitivity to feminist issues, playfully challenges her position. As I shall show in the remainder of my analysis, dissonance in Gipshut's other narrative is not grounded on moral or ideological incongruities between the fictional world and that of the narrator and implied reader - as is the case in the Hans/Veronika narrative. Rather, it is primarily a product of Hensel's unconventional narrating.

Though (to no one's surprise), the initial tension between Anna and Paul gets transformed into love, and though after the Siethener See episode everyday reality returns to the lives of the two scientists, a certain amount of dissonance still remains. Even in the remaining sections, the plot is so obviously contrived that there never is any doubt about the narrative's fictionality. The storytelling shows no concern for matters of causality, logic, or psychology. For example, there is no satisfactory explanation of why the funding for the project was so suddenly cut and why the team's discovery was never made public. Also, as unrelenting as Anna and Paul are during their pursuit of the volcano, they do not seem too disappointed when suddenly their unique discovery gets 
shoved under the proverbial rug. In fact, they soon pursue their new jobs with equal passion and missionary spirit, and they are now ashamed of having wasted their time in the pursuit of such an "unnütze Hypothese" (215) and "fossile Irrtümer" (217). What they fail to realize, however, is that their new project is just as unreal and illusory as their chasing after the volcano. What they call "die Realität" - the prospect of Berlin as "die Mitte einer Metropole und von nun an Weltgeschichte" (215) - is nothing but the construction (and reconstruction) hype of a country desperately in search for a new identity. And finally, the rapid fizzling of their story's plot in the last few sections, including its unresolved ending, is a letdown even to the most forgiving reader. Yet such an ending, which really is not an ending, perfectly fits the dissonant narrating in the Anna/Paul story.

One other factor contributing to the narrative's particular form of dissonance is the narrating agent's creative play with language, which, aside from giving the two geologists' story its ironic humor, exposes its artificiality. Entertaining the reader by telling a good story certainly plays a major role in the Anna/Paul narrative. Since critics such as Jill Twark, Lyn Marven, and Frauke Meyer-Gosau give some very insightful analyses of Hensel's play with language, and since Hensel's language is not really the focus of my discussion, I will only briefly touch on this subject. In general, the narrating agent's fondness for play with language is revealed by the many embellishments and the abundance of descriptive detail with which it brings to life the two geologists' adventurous search for the volcano. Particularly noteworthy are those passages where the clash between the language and what this language describes becomes a source of great wit and comedic humor. A similar kind of dissonance between the telling and the told can 
be found in Veronika's story, but while in Veronika's case the irony is more subtle in order to protect her dignity, now the mocking and ridiculing are more playful as well as also intentional. I selected two humorous descriptions, both of which are about the pair's budding love. In the first example, the way the narrating agent describes Anna's and Paul's first and ultimately unsuccessful try at lovemaking turns the scene into a piece of pure, slapstick comedy. The passage reads as follows:

Der freie Geist, den Anna in den vergangenen Monaten gepflegt hatte, schrumpft dumpfmulmig und nach Öltuch riechend. Auch Paul Norg spürt plötzlich Schwachstellen in seinen Empfindungen, .... Seine ganzen zwei Meter Körperhöhe benötigt Paul Norg, um in vierfüßiger Stellung das Zeltdach hochzustemmen, und, als lebende Stütze, Anna vor der Verschüttung zu retten. Seine Hände halten sich bereits im Bereich von Annas Oberhemd auf. Die Knöpfe finden schon aus dem Knopfloch, und Norg wünscht sich Finger aus Samt, denn das was er entdeckt, ist nicht harsche Kruste, kein frigider Distelwuchs, nicht einmal das erwartete kühle Flachland - es ist der Urgrund einer Naturkatastrophe!

The stark contrast between the comedy of the situation and the dry, matter-of-fact like tone of the narrating is striking. The sense of sophistication evoked by both word choice and sentence structure, as well as the technical precision of some of the detail clash with the awkward and ludicrous nature of what is happening. Rather than calling things by their name, the narrator carefully circumscribes the pair's first attempts at intimacy. The personification of Anna's shirt buttons, for example, is a roundabout and at the same time humorous way of alluding to Anna's willing cooperation as Paul begins exploring her 
body. Even more comical are those instances when the narrating agent uses geological terminology to evoke Paul's awkward attempts at exploring the new territory of Anna's body. Not only does the narrator use figurative language to allude to Paul's expected rejection, but phrases such as "harsche Kruste," "frigider Distelwuchs, " and "kühle Flachland," with which the narrator describes the scientist's rather unscientific investigation, add yet another level of ironic humor to an already grotesquely funny situation. With this kind of fundamental incongruity between language and its implied meaning, Hensel diverts the reader's attention from the described action to the language itself, a language that has been manipulated in such a way as to reinforce the comedic humor of the scene.

One of most entertaining instances of the narrating agent's linguistic acrobatics is the description of the couple's lovemaking, which occurs, of all places, in the Siethener See.

Anna schluckt Wasser, als Paul seinen Fisch steigen läßt, einen aalstarken Halbmeterkerl, der sich gegen das Kaltwasser behaupten muß, der schuppenfrei rudert und flossenfrei schwebt, der als Köder verkannt und beinahe vom Karpfen beknabbert wird, der Wärme sucht und den ein Strom zur Rettung lockt. (177)

Once again, the narrating agent resorts to figurative language, a method that, considering the delicate nature of the action to be described, is certainly appropriate. Considering the place where the lovemaking occurs, however, the analogy with the lake's fauna is not only playfully fitting and but also a showpiece of Hensel's ingenuity and imagination. The storyteller's language transforms the event into something comically surreal, thus 
again calling the reader's attention to the narrative's textuality and reminding her of its constructedness.

The Gegenwelt that emerges as a result of the narrating in Anna and Paul's story is of a different kind than that in the Hans/Veronika narrative. It is based on a lighthearted and subversive play with language and narrative conventions. By mixing the real with the fantastic, by disregarding the laws of causality, and by foregrounding the discourse itself, Hensel thwarts the reader's expectation of an ordered, coherent, and meaningful fictional world and continuously exposes the text as artifice.

Ultimately, then, Hensel's play with Gegenwelten is more complex than one might first assume. What is wrong in Anna and Paul's world is a different kind of wrong than that in Veronika's and Hans's stories. On virtually every page of Gipshut's first narrative, the reader is conscious of things being left unsaid, of something fundamentally wrong in the two characters' lives. The disorder in Veronika's and Hans's world is based primarily on an intellectual (in the case of Veronika), moral, and ideological dissonance between the fictional world and that of the narrator and the implied reader. By presenting a clearly dysfunctional world in a manner that makes it seem normal, Hensel has her reader fill in the gap between what is and what should be and actively engages her not only in the making of meaning but also in realizing what is not right. The reader is thus confronted with a uniquely ironic situation in which the text itself speaks of one reality while the narrating reveals another. In the Anna/Paul narrative, in contrast, the dissonance is primarily a result of the telling itself. Here the disorder stems first of all from Hensel's laying bare her narrative's constructedness and its artificiality in the most literal sense of the word. Here, too, there is method in her madness. By presenting Anna's 
and Paul's story as a fairy tale, Hensel is reminding her compatriots of how unreasonable their expectations and how foolish their dreams are.

Dissonance is a significant characteristic of each individual narrative, and it also defines the relationship between the narratives. How these narratives are formally dissimilar has already been mentioned. Furthermore, the difference in historical time could hardly be more dramatic, and the same is true for the environment that shapes the characters' actions. With its differences each narrative represents an aspect of what one could call East Germany's voice, and the dissonance reinforces the novel's central metaphor, the new Germany's, but especially East Germany's, dividedness. As Wayne Booth once said, "[Interesting narrators] are reliable guides not only to the world of the novels in which they appear but also to the moral truths of the world outside the book" (Rhetoric of Fiction, 221).

\section{"ENDE"}

I want to conclude my discussion of Gipshut and the idea of disorder with a few remarks about the novel's strangely surreal and unresolved ending — the volcano's eruption. Strictly speaking, Gipshut ends with a Leerstelle, with a gap, that Hensel leaves up to the reader to fill. It is a gap in more than one sense. Not only does the fate of the three characters remain a mystery, but the unrealistic ending pushes the Hans/Veronika narrative into the realm of fantasy. Moreover, by ending her work with the playful, tongue-in-cheek “ENDE," Hensel foregrounds the text's fictionality one last time. One might call it a cop-out ending in the sense that so many questions remain unanswered, but then again, in the reunited Germany of the late 1990s, many questions were indeed still 
unanswered. Moreover, the novel's chaotic ending gives the reader one last taste of Hensel's penchant for mocking not only the reunited Germany's struggle to become one people but also those who confuse literature with real life.

If one were to look for meaning or at least a glimmer of order in the novel's chaotic finale, however, one would find yet one more proof of the novel's (and life's) many ironies. The volcano's eruption finally makes public what Anna and Paul were forbidden to reveal, but will they live to get a satisfaction? For Hans, the event means the fulfillment of his life-long dream to make history, but will the world know that he was instrumental in this historic event? And as far as the novel's overall topic of Germany's rocky East-West relationship is concerned, the volcano's eruption could be considered a blessing in disguise. Perhaps the narrator/Hensel is telling us that with the symbols of East Germany's political past blown to pieces, the slate is now wiped clean, and the two Germanys aree free to focus on a new order and a new common history. Seen this way, the eruption of the volcano could signify a perversely happy ending - at least from a West German perspective. ${ }^{69}$

\footnotetext{
${ }^{69}$ In her review of Gipshut, Katharina Döbler is somewhat critical of Hensel's subversive play with narrative conventions. She praises Hensel's skill and the book's richness of ideas but finds the narrating unbalanced. She writes, "Die subversiven Attacken auf eine ordentliche und deutbare Handlung, so vergnüglich sie anfangs zu lesen sind, bringen den Roman schliesslich doch um die Ecke." The novel has no "Nährwert," no meat to it, she announces. While I agree that after the Palast der Republik episode, the novel loses some of its effectiveness and imaginative force, I find Döbler's criticism a bit too harsh. It seems to me that she fails to take into consideration one of the central, if not the central, aspects of Hensel's approach to writing fiction, her subversive play with narrative conventions - her Spiel-Ästhetik.
} 


\section{Conclusion. Writing against Forgetting. Hensel's Weiterschreiben in}

\section{Gipshut}

The GDR-ness of Gipshut is unequivocal; indeed, one may even call it a paradigmatic example of Weiterschreiben. It certainly represents the kind of Weiterschreiben that Astrid Köhler describes in her book Brückenschläge. Hensel not only continued to write after the historical change, but as Köhler has pointed out, though Hensel soon turned from writing short stories to writing longer fictional narratives that span all of the GDR's history, certain aspects of her writing never changed. All of her works share the same basic characteristics: irreverent humor and wit, clever play with language, love for the grotesque, and creative narrating. Certainly, the topic GDR and new East is of central importance to Gipshut and, as shown in my discussion of Hensel's aesthetics of disorder, is not only the work's central theme but also informs the work's structure and Hensel's narrating. In Gipshut, Hensel also shows her affinity to the country's long tradition of local color writing. The novel is set exclusively in the territory of the former GDR, East Germany, and it deals with social, historical, and political phenomena specific to life in the post-WWII East. Particularly noteworthy is how Hensel manages to combine aspects of the country's past and present history into one single narrative and how the novel itself is transformed into a representation of the country's dividedness. Furthermore, the carefully composed snippets of GDR everyday life in the provinces that fill the pages of the Veronika/Hans narrative are reminiscent of the fictions by earlier generations of GDR writers such as Johannes Bobrowski, Erwin Strittmatter, or Günter de Bryn. Hensel's descriptions of her characters' everyday lives are informed by the same penetrating and critical look that we find in these writers' fictional narratives. 
She shares their keen eye for detail, and like them, relishes in focusing on the less obvious, the seemingly mundane aspects of her characters' lives. Gipshut is a piece of regional literature which parodies both the old and the new East; it tells of social injustices, of unfulfilled dreams, and of the significance of history in people's lives. ${ }^{70}$

Though Hensel's talent for observation and precise description takes the reader back into the country's socialist past, realistic is certainly not the proper adjective with which to describe her writing style. As Hensel herself has pointed out repeatedly, Erfindung (invention) is an essential ingredient in her art. The kind of truth she is interested in requires her to go beyond the surface and use non-realistic techniques. Indeed, Hensel's love for the fantastic and her penchant for grotesquely distorted reality link her with Irmtraud Morgner, one of the most creative and imaginative writers from the former GDR, ${ }^{71}$ Aside from the fact that with her novel Auditorium Panoptikum Hensel wrote her own version of Morgnerian magical realism (indeed, Köhler considers the novel a homage to Morgner), and aside from the fact that Gipshut is considerably less radical in its conception (and therefore more accessible to the average reader) than the earlier work, the novel still has a certain Morgnerian ring to it (Köhler, 207). Perhaps the most obvious connection between Gipshut and Morgner's post-modern style of writing are Hensel's frequent excursions into the world of fairy tales and fantasy. Her ironic

\footnotetext{
${ }^{70}$ I agree with Reinhild Steingröver who in her essay "'Not Fate - Just History': Soties and Histories in Tanz am Kanal and Gipshut" points out that though in Gipshut Hensel "[satirizes] the utilization of literature as a chronicle of the historical," this does not mean that she is arguing for the "irrelevance of history for the individual" (Linklater and Dahlke, Kerstin Hensel, 93).

${ }^{71}$ Hensel had the highest praise for Morgner's writing as expressed in her two contribution to the deceased writer, "TROBADORA PASSÉ (Irmtraud Morgner lesen I) and “TANZ IN GEFÄHRDETER WELT (Irmtraud Morgner lesen II)," published in her Sudelbuch, 100-108.
} 
humor, her playful wit, her love for the grotesque, and her fondness for parody are all qualities we find in Morgner's writing, and though her satire can at times be biting, Hensel, like Morgner, softens the blow with a thorough dose of comic humor, and she shares Morgner's ability to respond to the many wrongs in this world with laughter. Hensel writes, "Die Komik, . . ., ist für mich ein Lichtstrahl gegenwärtiger Literatur-die neue/alte Gesellschaft mit ihrer Sucht zur Gewöhnlichkeit, ist nur besoffen zu ertragen, besoffen, verliebt und mit klarem Kopf" (Angestaut, 102). Furthermore, just as is the case with Morgner, irony for Hensel, too, is more than merely witty play with language but a central component of her narrative technique, as reflected in her subversive play with narrative conventions and especially her method of dissonant narrating.

Another aspect of Hensel's aesthetics of disorder in Gipshut is the self-conscious exposing of the narrative's constructedness and fictionality. Like her compatriot Morgner, Hensel keeps deconstructing the fictional reality she herself has constructed, never letting the reader forget that she is reading a piece of fiction. Such distancing of the reader is not Morgner's invention, of course, but goes back to such political writers as Bertolt Brecht, Volker Braun, and Heiner Müller. Though Hensel is not interested in politics per se-i.e., party politics - she has a keen eye for such problems as social injustice, dogmatism, and conformism, and her writing is certainly political in the sense that with it, she wants to alert people to these evils. In general, Hensel's original way of manipulating the novel's narrative structure and her creative play with voice and mood have been an important aspect of the GDR's literary tradition ever since Wolf's Nachdenken über Christa T. 
With all its surrealistic detail, its absurd twists, and the disorderly narrating, Gipshut's fictional world becomes a metaphor of the existential crisis shared by people in East Germany and other eastern European countries at the end of the millennium. It is a crisis brought about by a radical break with the past and the sudden loss of the familiar combined with an unpredictable future. In response to the sudden disappearance of the GDR, Hensel felt the need to keep alive the memory of its people, its history, and its political system. She does not do so in the form of a nostalgic looking back, however. Rather she talks about the past with the detached and penetratingly critical look of an outsider and in a language full of irony and grotesque humor. In her essay "Über dem Jammertal. Vergangenheit - geschichtlich und gegenwärtig," Hensel notes that a writer, when looking at the world as a whole, must not just touch the sensitive spots of world history, but she must keep the wounds open, “die Schmerzpunkte nicht nur berühren, sondern die Wunden offenhalten.” A writer who takes her role seriously wants to combat nostalgia and forgetting because forgetting puts society in danger of repeating previous mistakes - “wer vergißt, muß wiederholen” (35). 


\title{
Chapter Three. "Wann, wenn nicht jetzt."72 Angela Krauß and the Writing of Life
}

\author{
"Dichtung-im Gegensatz zur \\ Biographie - ist die rücksichtslose \\ subjective Geschichtsschreibung des \\ einzelnen Menschen. Er setzt seine \\ kleine Geschichte vor das Panorama \\ der Weltgeschichte" (Angela Krauß, \\ "Mit der Zeit erzählen," 122).
}

\section{Introduction}

Angela Krauß confronts her reader with a different kind of Weiterschreiben than what we have seen in Hensel's Gipshut (and in Hensel's post-Wende fictions in general). In a way one might say that these two writers represent two different ends of the spectrum with respect to their ideas about writing, their themes, and their narrating. Furthermore, while the topos GDR is a dominant theme in all of Hensel's post-Wende fictions and all of her works show the distinctive characteristics of regional literature, the regionalism in Krauß's narratives is less obvious. Indeed, if we look at all of her post1989 texts, in two of them, the former GDR is not even mentioned nor are there any direct references to issues that are specific to life in the post-Wende East. The setting of her narrative Milliarden neuer Sterne (1999) is New York City and the city that the narrator-protagonist of her latest fictional piece, Im schönsten Fall (2011), calls home

\footnotetext{
${ }^{72}$ Angela Krauß, Ich muß mein Herz üben. Gedichte, 77.
} 
could be anywhere in Germany. ${ }^{73}$ This fact concerning Krauß's work is important for our understanding of Weiterschreiben because it reminds us of the danger of compartmentalizing writers and their works. Secondly, and more importantly, Krauß's post-Wende oeuvre shows that Weiterschreiben is a matter of degree.

In the FAZ review entitled "Im Auge eines Elches" of Angela Krauß's Weggekiusst, the author calls Krauß's books written after 1989 “Selbstversuche einer Ostdeutschen, um die Wahrnehmungsveränderungen nach 1989 zu registrieren.” (2). Central to all of her post-Wende fictions are her narrator-protagonists' attempts to answer the existential question that was on the mind of so many of her compatriots after 1989, “Wo bin ich hingeraten?" With the exception of her latest work, Im schönsten Fall (2011), Krauß focuses on the emotional and psychological effects of the changes brought about by Germany's reunification, and she deals with the various hopes and fears, the exhilaration and the disappointment people in the former GDR experienced after reunification. ${ }^{74}$ Krauß's narrators are exhilarated by their newly found freedom and by the sudden plenty of the new life that is ahead of them. But at the same time, they have to fend off feelings of disorientation and are constantly in danger of losing themselves in life's abundance. Her protagonists have two choices: either they take action, face the unknown, and begin a slow and at not always easy process of re-building their life and their identity, or they give up, let themselves be consumed by inertia, and turn into social

${ }^{73}$ A complete list of Krauß's fictional works and other publications is provided in the attached Works Cited.

${ }^{74}$ But even the New York narrative, Sommer auf dem Eis, is indirectly related to the topic of the historical turn. Though the setting is New York City, the narrator's decision to travel to New York, to leave behind her former life, and give in to her longing for freedom and her desire for exploring a world so completely unfamiliar to her, all this is inspired by and a reaction to the new historical reality. 
outcasts, Aussteiger. As Krauß once remarked in her essay, “Die Lage im Osten,” “. . . das Dasein gleicht einem nicht enden wollenden $\ddot{U} b e r f a l l$, den man elegant und lautlos wie ein Karatemeister parieren möchte" (my emphasis, 169). Aside from this former GDR/new East theme, Krauß's narratives also deal with issues of a more philosophical nature, such as reaching new self-understanding through careful observation and reflection and developing an appreciation for the seemingly unimportant things in life. One important characteristic for all of Krauß's narrators is that their searching always extends beyond their personal concerns and turns into an inquiry into general existential questions.

Already these few remarks show how Krauß's Weiterschreiben is of a distinctly different kind than Hensel's. Krauß focuses on depicting life in the post-unification present (and poses some questions about the future), her texts are more philosophical and reflective, whereas Hensel's work is more socially critical. The main focus of Krauß's fictions is the inner lives of her narrator-protagonists and their interaction with the world around them. While Hensel's fictions are laden with action and have well-defined plots, Krauß's narratives have only a minimum of action and don't really have plots. They are short, slow moving, reflective, and highly poetic. Like her compatriot Christa Wolf, Krauß draws heavily on personal experience, and in her fictions she weaves together autobiographical, fictional, and even fantastic elements. Although both writers are first of all concerned with the individual human being, with her personal development, and her relationship to the world around her, Krauß's fictions are devoid of the moral, political, and ideological engagement that characterizes Wolf's writing. These issues are important for Krauß only in so far as they affect the shaping of an individual's personality and her 
life, but they are not topics her narrators reflect upon. Her subject matter, Krauß explains in her essay, "Mit der Zeit erzählen," is the subjective writing of history rather than history itself - a lived history of life, "gelebte Lebensgeschichte" (my emphasis, 122).

For my discussion of Angela Krauß and the notion of a Weiterschreiben of GDRliterature, I chose her first post-Wende narrative, Die Überfliegerin, which was published in 1995, and one of her later works, Weggeküsst, published in 2001. Both texts deal with the life-changing effects of German reunification on people in Germany's new East while at the same time also evoking the GDR past in the form of the narrators' childhood memories. I chose these two narratives mainly because Weggeküsst is generally considered a continuation of Die Überfliegerin. Both pieces are written as first-person narration with both narrators having identical voices and personalities. In fact, the narrator in Weggeküsst is very much like an older version of the one in the earlier narrative. ${ }^{75}$ Die Überfliegerin describes the narrator-protagonist's first reactions to the changes that swept through the East after German reunification and traces some of the steps she takes to keep up with the changing times and find a new beginning. It is the diary of the narrator's literal and figurative journey in search of a new understanding of who she is and of the world around her. In Weggeküsst, six years have passed since the events narrated in Die Überfliegerin and more than a decade since the historical change,

${ }^{75}$ Furthermore, one of Krauß's more recent texts, Wie weiter, which was published in 2009 also fits with these two earlier narratives so that all three works could be called Krauß's post-Wende trilogy. Each successive narrative echoes the previous one in a number of ways. For example, at the beginning of the second to last chapter in Weggeküsst, the narrator asks herself, "Mein Gott, wie weiter?" thus directly announcing the title and central motif of its successor, Wie weiter (a connection also mentioned by Astrid Köhler). Last not least, all three narrators share the same friends, Toma from Die Überfliegerin makes a re-appearance in Wie weiter, and they all reminisce about the same childhood experiences. 
but not much has changed in the narrator's life: Still overwhelmed by life's material abundance, she has still not adjusted, and still paralyzed by her fear of the unknown, she is still struggling to find direction.

This chapter will be organized in much the same way as the previous chapter on Hensel's Gipshut. I shall begin with a section on Angela Krauß the writer and on her poetics. One important purpose of this section is to show how much Krauß's writing is influenced by the place where she grew up and where she still lives - the GDR/East Germany. Next, I shall discuss the two narratives in chronological order. In my discussion of these texts, I shall focus on Krauß's narrative method and show how in each narrative, form and content form a unified whole. Both texts give testimony to Krauß's highly poetic and idiosyncratic way of writing: she not only transforms life into art, but she also reminds her readers that art-the aesthetic - is an integral part of life. I shall give each text a close reading, identify its paradigmatic narrative and stylistic features, and then show how the GDR/new East topic defines each narrative's structure and its narrating. To maintain focus during the discussion of these narratives' textual, narrative, and stylistic characteristics and to avoid unnecessary repetition, I shall save my comments about the GDR-ness of these narratives and Krauß's Weiterschreiben for the chapter's concluding section.

\section{Angela Krauß, the Writer}

Just like Kerstin Hensel, Krauß started her writing career in the 1980s, relatively late in life, though she had always been interested in literature and art. She published her first longer narrative, Das Vergnügen, in 1984, but it was not until after the historical turn 
that Krauß really came into her own as a writer. Her fictional debut is her aesthetic response to a year of working in a briquette factory in Bitterfeld, south of Leipzig. Her stay at Bitterfeld was part of the required government program (a so-called Fördermaßnahme) for the country's aspiring writers. The piece deals directly with the life of the factory workers and describes the festivities of a single day - the day when the main character, Felizitas Händschel, turns eighteen and when the factory celebrates its seventieth anniversary. In the GDR, the book was advertised as an "Arbeiterroman" and a narrative about the working class, but in no way did it fit the pattern of social realism. It does not really have a plot or overarching theme, nor does it have a clearly identifiable protagonist — not to mention its open ending and its ironic undertones. This short fictional piece and most of the texts in the two collections of short prose pieces Glashaus (1988) and its West German edition Kleine Landschaft (1989) ${ }^{76}$ have a distinct local color quality. They are set in southern Saxony's mining communities and are filled with images of the local landscape and of the towns and the people from the area around Chemnitz and the Erzgebirge, Krauß's Heimat. Das Vergnügen and most of the short pieces in the two collections are written in authorial narration, but already in these early works her associative style of narrating and her use of irony undermine the narratives' seeming realism. Like her later works, these texts are characterized by Krauß's poetic vision and by a narrating that relies on images (Bildräume) rather than the realistic depiction of outer reality and where much is left unsaid. ${ }^{77}$ The narrative Der Dienst (1988), her only truly

\footnotetext{
${ }^{76}$ Kleine Landschaft includes just a few new pieces while most of the stories in the collection were previously published in Glashaus.

${ }^{77} \mathrm{Krau} ß$ uses these expressions to describe her notion of the poetic during a conversation with Jörg Magenau. "Die Realität zum Schweben bringen. Gespräch mir der Leipziger Autorin Angela Krauß über die Wende und die Wendeliteratur, über Bahnhöfe,
} 
autobiographical narrative, for which she was awarded the Ingeborg Bachmann Preis, stands out among these early works because its fragmented structure, its associative narrating, and its poetic language, and among her pre-Wende narratives, this is the work that most anticipates her later style of writing. ${ }^{78}$ The narrative is written in first-person retrospective narration and its subject matter is the suicide of Krauß's father, a GDR border police officer, who, disillusioned by the political situation in his country, took his life in October 1968. Already in these early works, one can see her concern with form, her love for subtle irony, and her use of a narrating that penetrates beyond surface reality. As Astrid Köhler points out in her chapter on Angela Krauß, in Krauß's early stories we can already see represented all of the elements so typical of her post-1989 texts. ${ }^{79}$

A decisive experience in Krauß's life was her father's suicide, which as Krauß mentions in the interview with Julie Klassen, instilled in her the urge to write (224). Another important event in her life as a writer was November 9, 1989, the day when the Wall came down, and the demonstrations in Leipzig that led up to the historical moment. In her contribution to the series "Reihe Generation '89" in the magazine Semper! Krauß describes how seeing history in the making and actually being part of the process left her speechless at first, but as time went by, the aftermath of this historical event provided her for over a decade with the material for her narratives. How much Krauß's writing has been affected by this unique historical event is reflected in the fact that all of her texts

Flugzeuge und Reisen, das Sichtbare, das Unveränderliche, das Politische und das Poetische," Freitag 13 Oct. 1995: III, IV.

${ }^{78}$ It is quite telling for Krauß's approach to her writing that even after the narrative was awarded the price Krauß kept reworking it and then published a longer and revised version with the title Dienst Jahre in 1990.

${ }^{79}$ Brückenschläge, 157-185. 
written after 1989 (with the exception of her most recent work) in some way or other deal with the Wende and its life-changing effects on the people from East Germany.

One of Krauß's earliest statements about being a writer is her essay "Erneuter Versuch darüber zu reden," which was published in 1986. Here she remarks how observing (Wahrnehmen) and waiting are the two essential components of her writing process. At the beginning, there are just a few notes and impressions, carelessly put aside until something fleeting, some coincidence sets in motion her desire to write. "Ein Objekt der Liebe muss sein," she explains. In the end, it may be just a glance, a strand of hair catching the light, a sound or a movement through which she encountered the object of her love. "Ist es [das Objekt der Liebe] da, kommt alles andere von selbst: Phantasie, Imagination, Konzentration, Klarheit, Ausdauer, Verantwortung, Lust an der Mühe” (“Erneuter Versuch darüber zu redern,” 85). Though especially in recent years, Krauß has been very willing to talk about her writing and about what motivates her to write, one of the central texts on this subject matter is still her lectures in poetics, the Frankfurter Poetikvorlesungen with the telling title Die Gesamtliebe und die Einzelliebe. Aside from providing important insight into the different dimensions of her aesthetics and about the function and purpose of art, she talks extensively about events in her personal life that affected her writing. To illustrate her point she intersperses her comments with numerous excerpts from her work, a method that shows the subjective nature of her writing. The Poetikvorlesungen are important also for the theme of Weiterschreiben in her work because they provide important insight into how much her writing has been influenced by the GDR, the place where she grew up. 
Like Hensel, Krauß emphasizes the importance of environment on a person's consciousness and how our experiences with the space and the people that surround us make us into who we are and define how we relate to the world. The individual does not exist in a vacuum, and this is especially true for writers, Krauß explains. In the third lecture of the Vorlesungen, "Die Körper, die erfundene Zeit," Krauß uses the metaphor of a scaffold to describe the relationship between environment and art. Time becomes history only through personal experience (das Erlebte), she writes, and when this happens, history — whether that of a specific country or world history —is like a scaffold that shines through the text from behind ("existiert die Landes- oder Weltgeschichte als Gerüst, das von hinten durchscheint”) (73). Personal history is for Krauß thus always also a reflection of world history, and more importantly, only through the history of individuals can one arrive at some kind of understanding of world history. In "Die Gesamtliebe und die Einzelliebe" chapter of the Vorlesungen, Krauß writes that it is one of the writer's tasks to realize world history and put it to a test in the history of an individual (53). After all, storytelling (Geschichtenerzählen) is a kind of history (Geschichtsschreibung) - a connection that in German is more readily noticeable than in English.

This linking of individual history to world history is a key concept in all of Krauß's fictions and not surprisingly so because she grew up in a part of the world in which people's personal lives were subjected to the capriciousness of history and politics. Though Krauß uses a different literary method and narrative form than Hensel to realize this connectedness between history and geographical space, this awareness that art does 
not exist in a historical, political, and social vacuum is an important connection not just between these two writers but also between Krauß and other GDR writers.

Certainly one of the more distinctive trademarks of Krauß's aesthetics is her emphasis on the physical, on bodily experience (she calls it Körperlichkeit) rather than on abstract thought, and herein lies one of the major differences between the two writers' (Hensel's and Krauß's) aesthetics. Just as our understanding of the world is rooted in physical experience, so Körperlichkeit constitutes for her the structural foundation of her writing, Krauß remarks. Knowing about the world is based on sensory experience; it is the result of intuiting, not reasoning. She explains that already during the first moments of our lives, we experience the world as consisting of bodies (bodies that are outside of us and that surround us), and it is from the constitution of these bodies that we acquire an intuitive knowledge about the "Beschaffenheit der Welt." It is this Körperlichkeit of the world - its bodies and its empty space - that informs her work. She writes, Meine poetischen Baugründe sind die Körper und der leere Raum.

Die Körper, deren Anwesenheit uns letztlich als Spiegel unserer eigenen Leibhaftigkeit dient.

Der Raum, der von Körpern freigelassene, von Körpern verdrängte und von Körpern umbaute Raum. (65)

Similarly, when talking to Julie Klassen, Krauß describes the physical/sensual nature of her writing as follows,

For me, everything has to go by way of the body; I forget rather quickly any thought that I don't feel. All of my assertions or undercurrents of a 
philosophical nature derive from a physically experienced existence, and the joy, threat, hope, etc. that is connected with it. (230)

She also compares the effect of the physical world on our consciousness to that of electrical energy. Charges, fields, and currents that the world around us gives off project themselves into our consciousness where they evoke in the artist a creative impulse, a socalled Gestaltungsimpuls, she explains.

Closely connected with her poetics of Körperlichkeit is Krauß's understanding of Form, i.e., of the physical dimensions or various shapes that surround us. She considers Form the driving force in mankind's interaction with the world and sees it as fundamental to art. But Form can have several different meanings. First, as artistic form it refers to that part of art that evokes in the reader or viewer an inner response and an intuitive reaction to the artwork. Tone, style, effect-are different names for artistic form. But form can also refer to the patterns and shapes inside of us ("unsere innere Formenwelt") that help us orient ourselves in the world and that build the basis of our reactions to the outside world. Thirdly, Krauß speaks of Landschaft, the physical qualities of a landscape, as "Großform" or as "die Gestalt der Welt." In fact, one of her main arguments in "Die Pultscholle" is that landscape plays an important and elementary role in the forming of a human being because Landschaft is die erste Großform [ ], von der wir uns umgeben fühlen, umrahmt, eingeschlossen, begrenzt, hervorgehoben — in euphorischen Augen gekrönt und in ausweglosen unterdrückt glauben. (13)

We may experience Landschaft as either the big nest into which we move after having left the small one (“das große Nest, in das wir aus dem kleinen überwechseln") or, 
in the worst case, as something foreign, as the wilderness into which we are pushed ("die Fremde, die Wildnis, in die wir ausgestoßen werden"). How exactly we relate to our surroundings, this is stored within ourselves - "in unserem psychischen Orientierungsgrad" (13).

Of particular importance for understanding the regional aspect of Krauß's writing is her relationship to landscape and in particular to the geological features of southeastern Saxony - the rugged mountains of the Erzgebirge and the Vorerzgebirge with their many small mining towns nestled in the valleys. The Großform of these mountains was instrumental in forming her consciousness and her poetics as proven by the fact that the Erzgebirge is a recurring theme in her writing ${ }^{80}$ From early childhood on, Krauß felt a strong emotional connection with the rugged serenity of these mountains that date back to the early days of the earth's formation. Her visits to this region in the former GDR, especially to the Radiumbad Schelma (the village where her grandmother used to live), left a lasting impression on her mind and inspired her writing. There was her admiration for the majesty of the mountains and her fascination with their many secrets hidden deep

\footnotetext{
${ }^{80}$ It is perhaps telling that Krauß begins her Poetikvorlesungen with a chapter that is not only named after a geological phenomenon of the Erzgebirge, the Pultscholle, but that deals directly with the importance of the Erzgebirge in her writing. And it is similarly telling that her only autobiographical narrative, Der Dienst, begins with a lengthy description of the Erzgebirge, of its geological features, and of its people. In fact, the story's first lines are among the more memorable beginnings of her work. "Das Erzgebirge, in seiner vorgegebenen Gestalt, liegt da als ein Gesteinskörper mittlerer Größe. Es ruht in seinem absoluten Gleichgewicht, in seinem Zustand erstarrt. So bietet es sich dem bloßen Auge. Tief im Innern des einst flachwelligen Rumpflandes jedoch begannen einst jene Bewegungen, die zu seiner Herkunft führten: . ..." (Angela Krauß, Der Dienst, my emphasis, 7). The calm, composed, and factual tone of the beginning starkly contrasts with the narrative's highly emotional and tragic content. But more importantly, it announces one of the central themes in all of Krauß's texts, the play with "Sein" (essence) and "Schein" (appearance) - the fact that often truth and what is really important lies hidden underneath the surface.
} 
within the rocky structures, but above all there was her great love for the people of this region, for their tenaciousness and for the quiet way in which they went about their hard and dangerous lives in the mines. ${ }^{81}$

One of Krauß's more important childhood memories is her grandmother's Weihnachtsberg. The Weihnachtsberg, a tradition specific to the region of the Erzgebirge, is a reproduction of the mountain range made from cardboard, glue, and paint that was traditionally used as Christmas decoration. The sculpture could be opened, so that children could marvel at the secrets (the caves and the underground tunnels of the mines) that were buried deep inside the mountain and that were normally hidden to the eye. The secret of the Weihnachtsberg taught the child Angela several important lessons about the world, about life, and about art. Not only is there more to the world than the eye can see-"eine Welt hinter der Welt" (15) - but also we are surrounded and permeated with the other, the unknown, and the unpredictable ("daß wir umgeben und durchdrungen sind von dem Anderen, Unbekannten, Unberechenbaren") (96). The mystery of the Weihnachtsberg made her understand the importance of feeling and intuition as a means of getting to know the world - "frei von Begriffen den Sinn [zu] fühlen" (16).

Another important insight Krauß derived from the rugged majesty of the Erzgebirge is related to the eternal sameness and self-containedness of the mountains. She came to realize that nature existed independently of mankind and was unaffected by human history; the mountains/nature simply existed. Though nature plays a central role in all of Krauß's writing, her notion of nature is not at all romantic. She considers man and

${ }^{81}$ Her love for this region is also inspired by her fond memories of her grandmother, a women who with her resilience, her toughness, and her can-do attitude left a lasting impression on her grandchild Angela. 
nature totally separate entities, and nature's disinterest in human fate becomes the source of a unique sense of freedom. How exactly Krauß perceives of this relationship between man and nature is most clearly expressed in section two of Weggeküsst. Every time the narrative's narrator-protagonist feels overwhelmed by life and is in danger of falling apart, she escapes to the zoo and simply watches the animals. She describes her experience as follows.

Ich trete also vor so ein Tier hin. Es weiß nichts von mit, ich bin ihm vollkommen fremd. ... Ich bin ein Mensch wie alle anderen für das Tier, . .., fremd aber nicht neu. ... Ich muss nicht fürchten, daß seine Neugier mich trifft und mich in etwas verwickelt. Es hat mich in meinem Fremdsein einbalsamiert wie eine Mumie. Es will nichts von mir. Aber es wartet auf mich. (my emphasis, 25)

Since the animals have no interest in her, they ignore her. They simply go about their business, have no expectations, and make no demands. For Krauß, and for the protagonist in Weggeküsst, this "Fremdsein" and disinterestedness are both liberating and comforting because they allow a person to simply be and be herself.

Krauß repeatedly emphasizes that her central concern in her fictions is with the individual human being. She has no interest in portraying some kind of objective reality. All it takes is a single person, someone she happens to pass by in the street, to arouse her curiosity and desire to write. Her most intimate impulse for writing, she assures us, comes from those who have lost their sense of belonging, who suddenly find themselves outside of society and are trying to recover some sense of stability - a description that directly applies to the narrator-protagonists of the two texts to be discussed (57). 
Though Krauß has never been interested in matters of politics or ideology, on a personal level, she seems to have been much more deeply affected by the historical turn than Hensel. She repeatedly refers to the sense of freedom she suddenly felt when the borders to the West opened, and by freedom she means the opportunity for getting to know new places and cultures, meet different people, and gather new experiences. Suddenly "das richtige Leben" was waiting for her, she remarks in her essay "Die Lage im Osten" (170). Suddenly, she was part of a previously unknown plenty. Around every corner something new and exciting was begging for attention, and she did not know where to turn. When there was still a GDR, her desire to write grew out of her need to satisfy her hunger for life. She wanted to conjure up the illusion of plenty so as to escape the ever-present sense of sameness and to preserve her sense of individuality. Schrieb ich nicht, um einen Überfluß herzuzaubern, aus Lebenshunger? Aus Angst vor den sich zu sehr gleichenden Lebensgeschichten, aus Mißtrauen dem Gleichmaß gegenüber, zur Rettung des Eigensinns vor dem Gemeinsinn? (169)

Now, however, writers are surrounded by abundance. "Wir leben im Überfluß," she announces, and we only need to know how to deal with it. Indeed, this abundance is a like a double-edged sword. It is inspiring and provides the writer with a wealth of experience, but it can also be overwhelming and challenging (a notion that, by the way, is a central theme in Weggeküsst). As life became richer, noisier, and offered more diversions, it also posed new challenges. The main threat is superficiality, Krauß explains, and to escape it, the writer must distance herself from the distractions and 
penetrate to the essence of experience, to the Unsagbare - to that which cannot be put into words.

One of the challenges Krauß found herself confronted with after the historical turn was that all of a sudden life as she knew it no longer existed. In the Poetikvorlesung "Die Körper, die erfundene Zeit" she describes how almost overnight, the Erzgebirge that she knew from childhood on and with which she felt such a deep connection had ceased to exist. The mining towns and their people, representatives of a particular section of life in the GDR, had suddenly become history. Aware of this loss, Krauß keeps being haunted by the question, "Zerfällt meine Lebensgeschichte, weil ihr der Rahmen genommen wurde, der ihr Form gab?" (78) This question then gives rise to the narrative Sommer auf dem Eis whose narrator is confronted with exactly the same question. In this narrative, it is her childhood past that gives the protagonist the strength to deal with the challenges and insecurities of the present. But Krauß does not idealize the past. She admits that the social and economic changes as a result of the Fall of the Wall pose an existential threat especially to those living in the more remote regions of the country, but in her eyes, this unique historical event also gave them something very important-time. During the years of the country's existence, their time belonged to others. It consisted of hours spent working at factories and was counted in "Maschineneinheiten." Time then equaled “Abhängigkeit, Unfreiheit, Zwang," since they were never allowed to make use of time the way they wanted to (79). Though now people may be without work and they may have lost the comfort of their previous life, but they suddenly and unexpectedly got back their time. "Dafür hatten sie_plötzlich und unerwartet_ihre Zeit zurückbekommen" she writes (80). For her, time is never lost, Krauß says at the end of the chapter, even if it is 
time from yesterday or the day before yesterday. It is always present and does not stop being time simply because it has passed.

Was ich auch mache, die Zeit von gestern und vorgestern ist immer dabei, betörend und beunruhigend, hört sie nie auf, Zeit von früher zu sein, weil sie immer dabei ist, sie hört gewissermaßen nie auf, Zeit zu sein, weil sie nicht vergangen ist. (82)

It is telling that Krauß's last lecture of the Poetikvorlesungen carries the title "Die Vorfreude." For her, art is a combination of "Wehklage" and "Vorfreude," but it is the "Vorfreude," the joyous anticipation of the other, of the unknown and the unpredictable, that is the driving force behind her artistic creation. "Es ist etwas Alltägliches und etwas Ungeheuerliches zugleich,” she writes, “daß wir umgeben und durchdrungen sind von dem Anderen, Unbekannten, Unberechenbaren" (96). That her writing springs out of a deep, almost sensual connection with life, as expressed in her notion of "Vorfreude," is made even more explicit in one of Krauß's remarks to Julie Klassen. In order for something that happened in the past to be transformed into art, she tells Klassen, the memory has to be spontaneous and has to be relived.

[ ] I am completely dependent on what's alive. I remember something and at that moment I experience it again. That's all I can write, I can only write with this hot current that sometimes courses through me. (227)

If we really want to see what the world has to offer and experience discovery, change, and renewal, Krauß concludes in her fourth lecture, we must free ourselves from, indeed even forget, our pre-existing concepts and from the knowledge we worked so hard to acquire. We need to let go, give up our desire for control, and let ourselves be taken 
over by the otherness and strangeness that surrounds us (98). This letting go is the essence of art.

I shall conclude with a few remarks about Krauß's narrative technique. One of her more telling comments about the way she writes is a remark she made to Julie Klassen. "I am actually a poet," she said. "Only externally do my books resemble prose" (227). This explains why some readers and critics have difficulties relating to her writing and find fault with her narratives. Indeed, if one looks at all of Krauß's post-Wende tetxs, one can see a clear development towards an increasingly minimalist, associative, and poetic way of narrating. Especially her most recent text, Im schönsten Fall, seems more like a prose poem than a narrative. It reads like a collection of ponderings and philosophical observations about Krauß's most favored subject matters, love, people, technology, and the universe. And not surprisingly, before she wrote Im schönsten Fall, Krauß published her very first collection of poetry with the telling title, Ich muß mein Herz üben.

One important characteristic of Krauß's fictions is their subjectivity, a quality they share with the writing of her famous compatriot Christa Wolf. Indeed, what Krauß says about her preference for using first-person narration echoes Wolf's own remarks about her writing and her method of subjective authenticity. Like Wolf, Krauß starts from personal experience. The background of much of her narrating, and this is especially true for her post-Wende texts, is autobiographical, but never are her autobiographical self and her narrator identical. "The narrative 'I' figure who performs is an actor. I, Angela Krauß, have written a role for her," Krauß explains to Julie Klassen (226). Why did Krauß decide to change from authorial to using exclusively first-person narration? Because it was "the biggest challenge," she tells Klassen, and because she needs challenge in order 
to get started. As for Wolf, for Krauß too, writing is a means of self-searching and a path to self-understanding. In her lecture "Pultscholle" she explains, "Ich fand also zum Schreiben, weil ich nichts verstand. Ich schrieb um zu erkennen. Ganz von selbst erfuhr ich Schreiben als Erkenntnisweg. ... Schreiben ist mir Suche, Entdeckung, Erkenntnis" (my emphasis, 25). When talking to Klassen, she compares writing to what happens to us while traveling. Encountering other cultures, she explains, one "experience[s] something entirely new about oneself and about the world in which one is used to living half blind" (227). Though Krauß's writing is not politically motivated, it is, like Wolf's texts, informed by a utopian vision, by a belief in the beauty of life and a longing for life, and all of this she intends to share with her readers. "Ich glaube an das Leben als Ideal, an das Leben als Sehnsucht, als Begehren, und daß jeder dazu geboren ist, an diesem Kunststück zu arbeiten," the narrator-protagonist in Sommer auf dem Eis thinks to herself-thoughts that are most certainly shared by the author (48).

\section{Die Überfliegerin. Caught between the 'No Longer' and 'Not Yet'}

In Die Überfliegerin Krauß deals with the paradoxical, almost schizophrenic reality East Germans found themselves confronted with immediately after the historical turn. It is Krauß's artistic response to an all-too-common post-Wende phenomenon among East Germans - their sense of displacement, rupture, and irreversible loss. The narrative's story takes place five years after reunification, and it is (not surprisingly, I might add) the least unified of all of Krauß's post-Wende texts. Indeed, I shall argue that the narrative's lack of unity is not a sign of flawed writing but the aesthetic realization of the work's main theme - the narrator's feelings of inner disorientation and fragmentation. 
Fragmentation in Die Überfliegerin is the central component of an aesthetics that is designed to capture the emotional and psychological trauma of a society in the midst of dramatic transformation.

\section{A. The Story}

Die Überfliegerin has a clearly definable plot though the order of events remains ambiguous. The text is divided into three separate narrative units - much like chapters in a novel-alhtough the first chapter forms a self-contained narrative unit and stands apart from the remaining two chapters. Each chapter has its own distinctive plot, setting, storyline, and narrative rhythm, and together these parts represent the different stages in the narrator/protagonist's quest to conquer her sense of paralysis and reconnect with the world around her - a world that, as she puts it, fell apart virtually overnight.

Chapter One is set in the narrator's small and confined Leipzig apartment, where she has locked herself in for five years (ever since the Fall of the Wall), paralyzed by her fear of change. The narrative begins at exactly that moment when the woman decides that it is time for change, time to overcome her inertia and act. Thus, she embarks on a highly idiosyncratic preparatory ritual to ready herself for her journey into the new world. First, she strips the walls of her apartment, where the different layers of wallpaper represent the past lives of the room's inhabitants and, implicitly, the GDR's collective past. Then she proceeds to take apart her grandmother's sofa, a representation of her personal past. Her intention is not to destroy but to get to the source of things and then use her knowledge about the past as a building block for her new future. "Ich fange von vorne an," she explains. "Ich zerlege alles bis auf das Skelett. Und dann setzte ich es fehlerlos wieder 
zusammen" (40). In order to understand who she is right now, so she reasons with herself, she must get to the root of things, much like an anthropologist who studies old cave paintings. ${ }^{82}$ While figuratively as well as literally tearing down her old life, various childhood memories flash through her mind-scenes from her visits with her grandmother in the Erzgebirge, various memories related to the presence of Russian military forces in her hometown, and thoughts of her Russian childhood pen pal Toma. Repeatedly, she reflects on the topic of entropy and on her innate fear of chaos, but when the pressure becomes too overwhelming, she either turns her thoughts towards the industrial landscape of the Leipzig train station or she tries to imagine the lives of her neighbors, the Händsch couple, who unlike her, have long since adjusted to the change. Once the narrator leaves the safety of her apartment, her inability to function within the changed reality outside her room is only too evident. She turns into a helpless child and becomes an easy victim to the Händschs' enterprising talents. The couple uses the narrator's confusion and coerces her into signing a life-insurance contract. ${ }^{83}$ The narrator finally escapes to the dark safety in the cellar of her apartment building, and the chapter ends with her hovering in a corner, surrounded by the dismantled sofa and balls of wet wallpaper, still hiding from life and waiting for what is going to happen next.

The second chapter begins with a direct reference to the very beginning of the book. "Fliegen wäre schön," the narrator ponders as she looks out of her apartment's

${ }^{82}$ Looking at the bare walls and the faint markings of the lives of its previous tenants, the narrator compares her room to a tropical cave that is filled with the smells and signs of an earlier, unknown human existence. She says, "Ich bin in eine Grotte getreten, an deren Wänden Spuren uralter Zeichnungen haften: zarte gebogene Linien, fliehende Tiere" (20-21).

${ }^{83}$ It is ironic and funny that the narrator, a person who is paralyzed by her fear of falling victim to the chaos outside her apartment, signs up for a life insurance. But the scene also shows that she cannot forever hide from the world outside. 
window, contemplating the world outside (9). Now, at the onset of the second chapter the woman announces, "Fliegen ist schön." The wish became reality, so it seems (53). ${ }^{84}$ Suddenly shifting from present tense to retrospective narration, the narrator continues to relate her experiences during a trip across the United States. She has decided to travel West and explore that part of the world that until recently had been inaccessible to her, but whose values and life style meanwhile have become an inseparable part of her country's current and future life. During her travels across the country, she visits three different destinations, each of which is representative of a specific aspect of contemporary America: Minneapolis, Minnesota; Madison, Wisconsin; and San Francisco, California. For the first time in her life, the narrator finds herself exposed to a life marked by freedom, individualism, and diversity. The wide-open country and the sense of space starkly contrast with the confined world of her Leipzig attic room. It now seems as if the past no longer exists, and magically freed from the memories about her old life, she immerses herself in the newness of her experiences. The chapter ends with a climactic but also bizarrely unreal scene in a second hand shop in San Francisco, run (not surprisingly) by two transvestites. Surrounded by objects that speak of a past and a life she never knew, and overwhelmed by life's plenty, the narrator slowly sinks into a pile of clothes. ${ }^{85}$ "Ich war ein Teil einer Vielheit, von der ich nichts geahnt hatte," she remarks,

\footnotetext{
${ }^{84}$ The narrative's title announces one of its central themes that of the narrator's journey during which she überfliegt, flies across in the sense of visits, the former two Cold-War rivals, the United States and Russia, in order to familiarize herself with the new political and economic realities of the post-1989 world, and she hopes to find a way to reconnect with the world. I will elaborate in more detail on the ambiguity of the title's meaning in a later part of my discussion.

${ }^{85}$ Unlike the couch and the wallpaper in the Leipzig chapter, both representing the suffocating and paralyzing influence of the past, the second-hand clothes speak of a past that in its foreign-ness and abundance the narrator experiences as liberating.
} 
and embracing her newly found freedom, she savors the knowledge that there is a multitude of possibilities for her to choose from (85). But which of these many possibilities will be the one for her? At the end of the chapter, we find her dressed in men's clothes, more confused than ever and wondering, "ach, in welcher Welt wollte ich wer sein, wenn man schon die Wahl hat?" (90).

While the narrator's trip through the United States was a journey into yet unrealized possibilities, her next destination, the post-Wende Moscow, takes her into a world that is a strangely distorted, almost eerie mixture of old and new, past and present. It is a world that represents the "Gleichzeitigkeit des Ungleichzeitigen" (the simultaneity of the un-simultaneous) as Astrid Köhler calls it (169). Unlike in the United States chapter, where she was living solely in the present, now images and scenes from the past resurface. But she soon realizes that her memories of pre-reunification Russia and the Russians (themselves perhaps already an idealization) no longer match life in the Westernized East. While some people, including her childhood pen pal Toma, have embraced capitalism and are now driven by an almost uncontrollable desire for acquisition, others have given up on life and have escaped into lethargy. The Russia she once dreamt of no longer exists (if indeed it ever did). Wandering aimlessly through the dark and dingy labyrinth of the courtyards near Toma's house, the narrator senses the paralyzing influence of the past and suddenly feels trapped. "Meine Zukunft irrte durch die weite Welt," she remarks, "und plötzlich rannte sie in einem Käfig im Kreis" (111).

One day, during her walk through the neighboring courtyards, the narrator is lured by Serjosha (a young man, who like her is unable to adjust to the changes in his country) and by several old women into a cave-like, dimly lit basement room. Here she meets the 
matriarchal Mütterchen Aglaja ${ }^{86}$ The old woman tries to persuade the narrator to stay and give up her quest and then decides to marry the narrator off to the alcoholic Serjosha. The narrator frantically rushes out of the room, jumps into the Chrysler of her friend Toma's husband, and commands the chauffeur to take her to the airport. As the car races through the busy streets of the post-Wende Moscow, the plot takes a turn towards the fantastic. The Chrysler shoots into the air like an airplane, and as the narrator finds herself suspended between life and death, images of chaos race through her mind. Though fearing for her life, the narrator also experiences a new kind of excitement about life. "Ich will nicht sterben," she shouts. The narrative then closes with the chauffeur's announcement, "Achtung! . . wir landen” (124). With this reference to flying, Krauß has the narrative loop back to the narrator's wish at the beginning of the Leipzig chapter, "Fliegen wäre schön," but the mention of the landing provides an albeit false sense of closure (9). This shift towards the surreal in the chapter's (and the narrative's) final scene is remarkable because it catapults the narrative onto a different level of meaning. As Elizabeth Mittman has pointed out, the narrator/protagonist's magic car ride "pulls Krauß's work into a startling new utopian space, as she makes the grand gesture that flings all here-and-now-ness aside." While the ending offers no real solution to the narrator's predicament - she is still just as confused as before - this shift towards the fantastic adds a positive, indeed an uplifting tone to what is a slightly terrifying experience. To continue with Mittman, "the vision of death itself seems to carry a utopian

${ }^{86}$ The old women and especially Mütterchen Aglaja, the "kleine Alte" who is sitting on a torn-up divan (the connection to the grandmother's sofa is hard to miss), are reminiscent of the narrator's grandmother and together they represent the power of the past. But unlike in the first chapter, this time the feelings evoked by these matriarchal grandmothers are exclusively negative. 
charge as a moment not of loss, but of transfiguration in active flight" ("On the Raod to Nowhere: Utopian Geography in Post-Unification Literature,” 352).

\section{B. Narrative Structure and Rhythm in Die Überfliegerin}

The central theme and defining aspect of the narrative's composition and structure (as reflected in the previous plot summary) is the notion of fragmentation, and it is realized in different ways and on different levels. There is first of all the narrative's threepart division with each chapter forming a self-contained narrative unit. In addition, the shift from present tense to retrospective narration between chapters one and two further emphasizes the sense of rupture between the Leipzig chapter and the remaining parts of the narrative. But fragmentation is also a structural principle within the individual chapters, and especially so in the Leipzig chapter, so that the irregularity of the narrating comes to represent the different phases of the narrator's emotional instability and inner fragmentation.

In all three chapters, the structure is episodic. The flow of the narrating is constantly interrupted by ellipses and temporal gaps. As a result, the work reads more like a collage of various types of discourse and dramatic scenes than a coherently developed narrative. But how exactly these different segments are assembled depends on the main theme of each chapter and greatly varies with each chapter. ${ }^{87}$

The Leipzig chapter is the most fragmented of the three, and its narrative rhythm is the most irregular. It is also the only chapter that is narrated primarily in interior

${ }^{87}$ The different types of discourse that Krauß employs are: straight narration, highly poetic and detailed descriptions, personal observations and reflections, reported dialogue, and memory scenes. 
monologue. Chapters two and three are narrated almost exclusively retrospectively, with just a few switches to present tense. The many sudden temporal leaps between memory monologue and narration, the numerous gaps in the narrating, and the implicit ellipses all speak of a mind constantly on the move.

The most distinctive structural and thematic characteristic of the Leipzig chapter is the narrator's repeated nostalgic evocations of the past. The back and forth between the description of what is happening right now and some remembered scene keeps disrupting the linear progression of the story. The result is a unique rhythm of progressing and regressing. The memory monologues are not the only elements that disrupt the flow of the narrative, however. In most of the Leipzig chapter, the action consists primarily of the narrator's consciousness and only to a lesser extent of what she does. As dramatic as her tearing down the wallpaper and her violent struggle with her grandmother's red sofa may seem, the real drama of the chapter lies with what happens inside her mind ${ }^{88}$ Aside from recalling scenes from her childhood, much of the narrator's time is spent contemplating the world outside her window and listening to the sounds of her fellow tenants. The outside world attracts and at the same time mystifies her. Everything looks as it always did, but this sameness is deceptive, she tells us. In reality, everything has changed, and she no longer understands how things work - "wie die Welt zusammengesetzt ist" (38). She explains,

Eines Morgens wachte ich auf an einem mir unbekannten Ort, der mit einigen vertrauten Zeichen sich stellte, als sei es der alte. Ein Verwirrspiel,

${ }^{88}$ The only longer, i.e., uninterrupted piece of narration occurs towards the end of the chapter, during the scene in Herr and Frau Händsch's (both ambassadors of the new East) apartment. 
das bereits fünf Jahre zurückliegt, und das zu durchschauen mir bis heute nichts genützt hat. (39)

Though she is intimidated by the seeming chaos outside her room, turning her attention to this other world - whether it is by listening to the sounds of her neighbors or by watching the industrialized cityscape of the Bahnhofsgelände below her windowoffers a temporary escape from her inner turmoil. The familiarity of these sounds and sights give her the illusion of belonging. They are the proverbial straw to which she clings in order to reassure herself that she is still part of the same world as everyone else around her. But these feelings are deceptive, she knows. As familiar as she may be with these sights, they are now all part of a foreign world - "und das alles steht in einer fremden Welt," she remarks - a world that she no longer knows or understands (10). To avoid the fear evoked by this realization, she turns her thoughts to the past, but even her memories offer no relief. The knowledge that this past is forever lost becomes too painful to bear. Thus the narrator seems trapped in a vicious cycle; no matter where she turns, she finds herself confronted with the fact that life has changed, that nothing is the same. Still, there is one way she can calm herself, and this is by turning to the technoscape outside her window and by focusing just on what she sees, on the objects themselves without assigning them any content or meaning. The following is the description of one such moment:

Der Mond steht über dem Bahnhofsgelände, wie im Morgenblau, die Parallelen der zwei Schienen eines Gleispaares treffen sich im Unendlichen, hinter den steinernen Fluchtpunkten der Schornsteine und der Lichtmasten, der Kabelbäume, hinter dem Gerätewald. (27) 
Passages such as this run through her narrative like brief musical intermezzos. Striking is the calm tone and the simple but highly poetic language. She focuses on the thing-ness of what she sees, and similar to a camera eye, she captures colors, shapes, and the play of light outside her window. Capturing the mere being and the eternal sameness of this material world gives her a momentary feeling of contentment. Sometimes, in her search for a sense of permanence and order, she thinks of her neighbors and imagines them performing their simple, daily routines. Aside from recalling past experiences and distracting her mind with contemplating the world outside her apartment, the narrator repeatedly engages in self-searching reflections upon her present situation. Why can she not let go of the past and adjust to the new life as her neighbors and the rest of the country have done? Why her inability to love, and why her paralyzing fear of chaos? As hard as she tries, she cannot completely shut out the signs of change. Disorder and entropy, she is forced to acknowledge, are part of life. Railroad accidents, airplane crashes, or her neighbor's head injury, all this reminds her that there is an element to life that is beyond human control.

Thus, what initially seems like a random collection of various kinds of discourses, in the course of the chapter becomes a carefully crafted map of the narrator's mindscape. Her frequent references to the past are not only indicative of her difficulties in letting go of her old life, but they are also part of her working through the past so as to move on with life. Contemplating the world outside her apartment offers a reprieve from her inner turmoil, but it is also part of her efforts to stay connected with this world. Central to the narrator's thoughts, however, is her preoccupation with action, be it her own actions, 
those of others, or her inability to act. "Eine Tat.... Wie hat es mich nach einer Tat verlangt!" she thinks to herself while she is dismantling her grandmother's sofa (24).

Once the dissected sofa and the neatly folded sheets of old wallpaper are safely stacked in a dark corner of the cellar, Frau Händsch, the narrator's neighbor, comes to her rescue and drags the helpless and exhausted woman into the safety of her apartment. This rescue is accompanied by an abrupt and significant change in the narrative's focus. The language shifts from the poetic language of the narrator's monologue to a straightforward narrating of action and reporting of dialogue. Although the chapter's final pages are still delivered in present tense monologue, the emphasis is clearly on what happens rather than on the narrator's thought processes.

The shift to narration of events at the end of the Leipzig chapter is accompanied by a distinct change in the text's rhythm and pace. With the emphasis on relating thought rather than action and with the constant shifting between different kinds of discourse, the Leipzig chapter had been progressing quite slowly in a stop and go fashion. But once the narrator has left her room and the focus is on action, the pace speeds up and the rhythm becomes more regular. This noticeable and decisive break in the narrating anticipates the narrating in the second and third chapters, where the retrospective reporting of the narrator's experiences and impressions becomes the preferred narrative method.

In chapter two, narrative structure and rhythm are defined first of all by the conspicuous absence of recollections and by considerably fewer reflective digressions. This fact is tightly linked to the changes in setting, plot, and theme between the two chapters. The claustrophobic atmosphere of the narrator's Leipzig apartment has now been replaced by the vast and spacious geography of the United States; overwhelmed by 
what she sees and experiences, the narrator is absorbed in the newness of the present. While slowly adjusting to the different time zone, she is able to forget the old time. She explains,

... nach sechs Tagen wachte ich das erstemal nicht mehr nachts auf, um für den Fortgang des früheren Lebens gewappnet zu sein.

Am Morgen war es in ein Loch gefallen und verschwunden. (62) $)^{89}$

Liberated from the burden of the past, the narrator experiences a sense of weightlessness that is reflected not only in the act of flying - she feels as if she had been born with wings and is flying "von ganz allein"- - but also by her total immersion in the here and now. In the Leipzig chapter she was distrustful of the present; now her fear seems to have dissipated. "Die Gegenwart kann so vollkommen sein, daß Fragen an ihr abgleiten wie dünne Männchen in Bergausrüstung," she says, exhilarated about the fact that she is flying (54).

Another decisive difference between the two chapters is the shift in narrative situation from present tense monologue to first person retrospective narration. As already mentioned, the Leipzig chapter is almost devoid of plot. Instead, the narrator's overly active mind and her roaming thoughts drive the narrative onward at an irregular pace, and the simultaneity of narration, action, and thought defines the chapter's narrative structure. In The United States chapter, by contrast, the switch to past tense narration considerably alters the temporal distance between what is being narrated and the moment of its narration. This in turn changes the focus of narrative from immediate representation of

${ }^{89}$ The allusion to Genesis, here, is a nice example of Krauß's subtle irony. As it turns out, the new life the narrator is embracing here eventually turns out to be an illusion. As she finds out at the end of the chapter, she may have changed worlds, but she cannot escape who she is. 
thought to retrospective reporting of events. In other words, the progression of the story as well as its narrative structure and rhythm are now defined by external phenomena, i.e., by the different stages of the narrator's travels across the United States.

With almost no remembered scenes and fewer reflective digressions, the narrating in chapter two is considerably more unified than in chapter one. The most frequently used forms of discourse are the description of places and people and the reporting of various conversations, and only rarely does the narrator comment on her experiences. ${ }^{90}$ In contrast to the highly poetic language of the Leipzig chapter, her descriptions are now more direct and factual with virtually no embellishing detail. This, for example, is how the narrator describes her first encounter with David, Julie's husband.

Er erschien im Nachtgewand, hob seine Arme und streckte seine langen Finger zu den Stacheln unter der Decke. Er hieß David; ich betrachtete ihn wie alles, was mir begegnete: als sei es in gleicher Größe nebeneinander gesetzt.

Wir fingen an, Getreidebrei zu essen, als Julie mit ihren Übungen fertig war und sich zu uns gesellte. Sie machte jeden Morgen die Canadian Airforce Exercises. (63)

${ }^{90}$ The only memory in this chapter is one from her childhood in the late 1960s. She is in a small, run-down cinema somewhere in Saxony, watching a Western with Yul Bruner. Three times she remembers the same theme and focuses on the same detail which brings forth the contrast between the world depicted in the movie and her world: Yul Brunner riding through the scorching heat of the Sierra Madre; outside the cinema, the first snow is falling; the air inside is heavy from people's wet coats. And she remembers that for a short moment in her imagination the two worlds, that of the film and hers, were merged into one. The tone of these memories is peaceful and idyllic, but mixed with a touch of irony. The scene reveals the woman's naiveté vis à vis American culture and the American way of life. All she knows about the country is based on the greatly simplified and stereotypical images of Western movies that, furthermore, were filmed in Spain. 
This is the language of a detached observer, and in her mind's eye, the narrator is simply playing back the scenes she witnessed during her journey westward. She lists and describes in the plain language of a reporter what happened. Never does she try to interpret or attribute any deeper meaning to these events. Although the temporal distance implied in retrospective narration would allow for evaluative commentary, the narrator delivers everything just as she experienced it, then, during her journey. At that time, it all seemed equally important_- “in gleicher Größe nebeneinander gesetzt.” In fact, ever since landing in America, she had stopped thinking about complicated connections (66).

The climax of the chapter occurs during her visit in San Francisco, and this is also when, unsurprisingly, the focus changes back to her thoughts. When relating her epiphanic experience in the second hand store, run by the two gay men, Sally and Tabury, she now returns to using figurative language and describes her emotions:

Durch den Aufschlag war etwas in meinem Innern durcheinandergeraten. Wie wenn man ein Kaleidoskop schüttelt, plötzlich ist ein neues Muster da, ein vollkommen neues Ornament aus den alten Bausteinen. (88) To explain how she suddenly felt this new sense of freedom and inner relief, she again employs metaphorical language,

Alles Flüssige in meinem Innern wogte und schwappte hin und her vor Heiterkeit, kichernd vor Erlösung, zusätzlich schienen sich die festen Bestandteile zu verflüssigen und schlingerten rhythmisch, weich und lachend, wie in einem Schlammtümpel, der Blasen wirft. (88) Everyday language may be useful for reporting what she did and saw during her explorative journey, but when it comes to describing her state of mind, she has recourse 
to poetic language. Only now, and just for a moment, do we get to hear the familiar voice from the Leipzig chapter.

Partly because of the fewer digressions and partly because the story covers a longer time period - several weeks rather than the less than two days in the Leipzig chapter-the story in chapter two moves at a much faster pace. Most of the chapter consists of summary (in itself a narrative method that creates the sense of speed and forward movement), and only occasionally does a passage of reported dialogue slow down the progression. The changes between the three major sections of the chapter (each section covers a different destination) are quite abrupt. They break the flow of the narrative and add to the chapter's hurried pace and its uneven rhythm.

In the final pages of her report about her travels through the U.S., the narrator focuses on describing her almost euphoric state of mind while encountering the West Coast's cultural diversity and its progressive life styles, but then the chapter ends on a rather subdued note. As excited as she is about having tasted freedom and having been introduced to life's rich choices, ultimately, this embarrassment of riches only increases her indecisiveness and paralysis and adds to the possibility of chaos.

Next we find the narrator on a plane to Moscow, the place for which she has felt a special fondness ever since childhood. It is thus no surprise that while she is still in the air, the past begins to catch up with her, and as memories begin to resurface, feelings of confinement and paralysis return. Just like chapter two, the Moscow chapter is written in first-person retrospective narration, and it, too, begins with a reference to flying, which is followed by the description of a dream the narrator had while in the air. The tone is now calmer and more subdued than in the previous chapter. 
One interesting connection with the Leipzig chapter is how, after the narrator's landing in Moscow, space suddenly became restricted again and the old sense of confinement returns. Waiting in line at the Moscow airport, surrounded by crowds of people, and feeling that she is being secretly watched overshadows her arrival in the Russian capital with a sense of unease and foreboding. Soon, one of her most frequently mentioned memories returns - that of the deserted Russian Kommandatura in the villa of the Schokoladenfabrikanten - and it is with these memories together with certain recurring images that Krauß establishes a thematic link back to the Leipzig chapter. ${ }^{91}$ Whether it is in the shape of the five old women who, sitting on their benches, watch with unmoved faces her every movement, or in the shape of a group of old men who are waiting in line with their empty "Stoffbeuteln" (cloth bags), or whether it is in the shape of a dark and dingy basement room lit by a dusty chandelier-literally as well as figuratively, the past, and with it feelings of paralysis and mental agony has once again caught up with the narrator. Similarly, the wide-open landscape of the United States has now been replaced by the suffocating atmosphere than emanates from labyrinthine structures of the courtyards near Toma's apartment.

Narrative structure and rhythm of the Moscow chapter are defined by the alternation between her lonely walks through the neighborhood, the hours she spends

${ }^{91}$ While in the Leipzig chapter, recollections of her grandmother were the most present in the narrator's mind, now, the most frequently mentioned memory is that of Toma and her euphoric and passionate letters, letters that speak of her enthusiasm for life, her optimism, and her unbounded energy - her "unabhängige tartarische Art" - qualities that the narrator herself is lacking but admires and longs for (108). Of the repeated images, the most powerful one is that of the fissures in the walls of Toma's apartment building and Mütterchen Aglaja's basement room. "Die Risse in den Mauern. Die alten Muster," she thinks to herself (119). They immediately remind the narrator of the cracked walls of her Leipzig apartment and implicitly of her former sense of fragmentation. 
with Toma, and her retrospective digressions. As in the previous chapter, narration and description are interspersed with passages of reported dialogue, and as before, the narrator offers no explanation or commentary. The climax of the Moscow chapter is the scene between the narrator, Mütterchen Aglaja, and a young man, Serjosha, in the eerie dark of the old woman's basement room, and as in the narrator's previous report about her travels through the United States, it again comes at the end of the chapter. Most of the scene is delivered as dialogue with some description of action, and the lack of commentary only emphasizes the grotesque and surreal nature of the scene. Moreover, not only does the narrator's magical car ride to the airport at the end of the book leave the ending inconclusive, but it also makes one wonder whether the narrator's two journeys may only have happened in her imagination.

On the one hand, the return of memory discourse in the Moscow chapter and the repetition of certain motifs and images from the Leipzig chapter tie these two chapters together. On the other hand, however, Krauß's choice of retrospective narration and the travel theme convey the idea of chapters two and three as a separate unit, which then brings out even more sharply the idea of rupture and disconnectedness between the Leipzig chapter and the rest of the narrative. This lack of structural as well as narrative unity is one of the most distinctive characteristics of Die Überfliegerin. The sense of fragmentation evoked by Krauß's narrating is not a sign of her having lost control over her material, however. Rather, it represents a creative merging of form and complementing content. 


\section{Narrative Tense in Die Überfliegerin}

The narrator's feeling of dividedness and her sense of having fallen out of time are also reflected in Krauß's unconventional manipulation of narrative tense, as shown in the way the narrating changes from present tense monologue in the Leipzig chapter to retrospective narration in the second and third chapters. By subverting the general expectation of fictional narrative as a unified and internally coherent artistic form, Krauß's narrating follows the demands of the story itself rather than obeying the rules of realistic narrating. Narrative tense usually provides a temporal axis for events that happen along different timelines. But Krauß also uses tense in Die Überfliegerin to depict a change in the narrator's relationship to her story (to the events narrated) and to manipulate the degree of closeness or distance between reader and story.

Because of the temporal gap between the moment of narration and when the recalled event happened, in past-tense narration, the emphasis is usually on relating events. Narration of thought is possible, but the temporal dissymmetry caused by the time lag calls attention to the narrator's filtering consciousness and thus takes away from the immediacy and spontaneity of thought presentation. Present-tense narration, by contrast, gives the illusion that experiencing and narrating happen simultaneously. Also, the reader is much less aware of the narrator's mediating function, and this creates the impression of her having immediate access to a character's thought processes and inner life. In general, present-tense narration lends itself better to the description of thought - the presentation of mental processes - than to the reporting of action. ${ }^{92}$

${ }^{92}$ While this lack of temporal distance can have a limiting effect when it comes to commenting on or evaluating the meaning of certain events or experiences, temporal distance, i.e., retrospective narration does not require such explanatory or evaluative 
Die Überfliegerin represents an interesting case study for the relationship between narrative tense and person. I have already referred to the change from first-person present-tense narration to first-person retrospective narration between chapters one and two, but this is not the only irregularity. Within the chapters themselves, and especially in the Leipzig chapter, there are some unusual shifts in narrative tense and these deserve special attention. I shall first turn to discussing the effects of the tense shift between chapter one and chapters two and three and then turn to a close analysis of Krauß's use of past-tense narration within the present-tense monologue of the Leipzig chapter.

The tense shift between chapters is accompanied by a change from internal to external focalization, and this change is reflected in the conspicuous absence of reflective passages. In the Leipzig chapter, the reader is granted direct access to the narratorprotagonist's conflicted thoughts, while in the remaining chapters of the narrative, the focus is on reporting her experiences without providing much information about their effect on her consciousness. The narrator tells us about the places she visited and the people she encountered during her travels. Thoughts are now reported retrospectively only, which considerably weakens their dramatic effect. Moreover, the temporal distance created with past tense narration keeps the reader removed from the narrator's experiences; her role changes from witness and participant to listener and observer.

But the shift in narrative tense between the first and the second and third chapter is important for one more reason. It creates a contradiction in the telling of the

commentary, as in the case of chapters two and three in Die Überfliegerin. This lack of commentary then creates an effect that very much resembles that of spontaneous narration. 
narrative - a friction that not only disrupts the work's unity but that is of utmost importance for our understanding of the text as a whole.

The most important ways in which readers find out about the temporal relationship between events in a narrative are the order in which action is narrated, change in tense, and strategically placed temporal markers. In Die Überfliegerin, however, temporal relationships are not that clearly marked. The Leipzig chapter, for example, most of which is narrated in interior monologue, starts out with a few sentences written in past tense. The United States and Moscow chapters, both of which are related retrospectively, begin with a short section of present tense narration, however. This strange switching is especially confusing at the beginning of chapter two. Because the previous chapter had been narrated in present tense monologue, the reader simply assumes that the narrative will continue in the same manner, so that the sudden and unexpected shift to past tense creates a rupture in the narrating. Similarly deceptive is Krauß's play with tense in the narrative's main motif_fliegen/flying. "Fliegen wäre schön" the narrator thinks at the beginning of the Leipzig chapter and then picks up this thought at the beginning of both of the other chapters. Only now, she uses present tense indicative ("Fliegen ist schön”). This change from wish to statement of fact makes it seem as if the narrator's travels had occurred after the events of the Leipzig chapter and that her wish is now becoming reality. But with the switch to past tense also comes a change in the temporal relationship between the woman's two journeys and the events in her apartment. Now it seems that her flying across the world took place earlier, before she began demolishing her room, and that perhaps she is simply reminiscing about her travel adventures while hiding in her basement. Such a restructuring of the temporal 
relationship between the Leipzig chapter and the travel chapters ultimately affects the narrative's meaning. The story would end not with the woman's magic car ride to the Moscow airport but with the image of her huddled in the corner of the basement still paralyzed by her fear of taking action and still not able to take charge of her life.

And then there is the question of whether the narrator is not simply imagining her journey. The many dreamlike and surreal scenes and the so obviously stereotypical and pre-fabricated images of life in the two countries and of their people, these facts suggest that everything we read in chapters two and three is perhaps merely a fabrication of her overly active mind. Such a reading would also be supported by the inconclusive ending of chapters two and three, when we see the narrator still as confused and undecided as at the beginning of her journey. ${ }^{93}$

Aside from this play with narrative tense when constructing the temporal relationship between the three chapters of Die Überfliegerin, Krauß's creative use of past and present tense narration within the narrator's interior monologue in the Leipzig chapter also deserves special attention. While the narrator relates her present thoughts and actions, she repeatedly changes to past tense narration. This in itself is nothing unusual because it is the conventional way of narrating memory and most of these passages are indeed true memory monologues - recollections of experiences from her childhood and of the more recent historical events. But in some of her past tense

${ }^{93}$ Astrid Köhler, too, is suggesting that the woman's journey was in reality nothing but a dream because of the dreamlike quality of the narrating. Parts of the Leipzig chapter have the eerie quality of nightmares, she argues, whereas the United States chapter reads like a wish dream. And the last chapter in particular is infused with numerous dark and surreal elements. She then interprets the chauffeur's announcement, "Achtung! ... wir landen!" as a complete awakening from a journey that ultimately was only a dream ("ein umfassendes Erwachen aus einer Reise ..., die letztlich überhaupt nur ein Traum war" (Brïckenschläge, 171-73). 
discourse, she refers to things that seemed to have happened only moments ago. These are actions that have a direct effect on the present and where the temporal distance to the now of narration is a matter of minutes only. The phenomenon represented by this second type of past-tense narration is what Genette calls interpolated narrating; I shall discuss its effect and purpose in Die Überfliegerin in the following examples.

Already in the narrative's opening lines, we can see inventive play with temporal relations and different kinds of past-tense narrations. As mentioned earlier, the Leipzig chapter begins with past-tense narration though most of it is written in interior monologue. Referring to what must have happened just moments ago, the narrator reports, "Plötzlich faßte ich mit zwei Fingern den Zipfel der Tapete unter der Zimmerdecke und ri $\beta$ sie von oben nach unten herunter. Ich stie $\beta$ das Fenster auf." After having announced the wish "Fliegen wäre schön"-most likely her thoughts as she was looking out of the open window - the woman then continues her story in present tense. “Gleich ist Mitternacht," she says. "Der Mond steht über dem Bahnhofgelände und bescheint die Gerätewelt. Die Kesselwaggons dampfen; sie reihen sich in zwei Bögen" (my emphasis, 9).$^{94}$ Once we pay closer attention to the narrating - to the beginning in medias res, to the shift from past to present tense narration, and to the two temporal markers "plötzlich" and "gleich"- we realize a strange incongruity in the way the narrating shifts between tenses. The sense of contemporaneity and immediacy of the past-

94 The remark "Fliegen wäre schön" is located, almost like a transition, between these two different kinds of narrative situations, past and present tense narration. As a result, the sentence's narrative function is highly ambiguous. If read as part of the past tense narration, the sentence "Fliegen wäre schön" can be read as free indirect discourse with the speech tag, "ich dachte," simply implied. If read in the context of the present tense narration that follows the sentence, however, the same sentence can be read as interior monologue, as a direct representation the narrator's thoughts while she is looking out of the window at the same time as she is uttering the wish. 
tense action is something that we generally connect with present-tense narration. Starting the narrative with this kind of friction not only calls attention to these initial lines, but past-tense narration also creates a kind of frame or link that connects the Leipzig chapter with the other chapters in the narrative, in which past tense is the primary mode of narration. This way, the interior monologue is contained, so to speak, within the retrospective discourse. Finally, these initial lines anticipate the rather unusual temporal relationship between past and present narration that is so specific to the Leipzig chapter. What is being narrated in past tense, here, is not some event from the distant past, i.e., true memory. Rather, these actions happened very recently, and they are also directly related to the present moment. In fact, they are being continued in the present.

One other example of this play with past-present relationships can be found when the narrator tells about her grandmother's sofa. The scene begins with the narrator describing (in present tense) the view of her room from the top of her ladder while she is taking a break from tearing down the wallpaper. Seeing her old green sofa standing at the wall immediately brings back memories of her grandmother, which are promptly related in the past tense as memory monologue. As if to emphasize this break in the narrator's stream of thought, these reminiscences are also set off from the remaining text by extra spacing so that they visually stand out. The next section begins with the word "plötzlich" (suddenly) which makes us expect that now the narrator is about to return to her story and continue her present tense description of what is happening next in her room. Instead, she describes the last moments of her struggle with the Sofaleib, using past tense instead of present-tense narration: 
Plötzlich faßte ich mit zwei Händen das Sofa an der Rückenlehne und riß es zu Boden. Es lag wie eine Puppe mit den Beinen nach oben. Ich schämte mich.“" (my emphases, 23/24)

Past-tense narration is here taking away from the drama and the immediacy of an event that is emotionally charged. Taking apart the sofa obviously symbolizes an important step in the woman's efforts to work through her past. Present-tense-i.e., simultaneousnarration would thus have been much more appropriate and certainly more consistent than the retrospective mode. After elaborating (still in past tense) on the final movements of the dying sofa, the narrator then returns to present-tense narration virtually in midsentence, “ In diesem Augenblick war unten das Radio angegangen,” she explains and then continues, "dort schläft Mario, . . ähnlich einem Säugling.” For a brief moment her thoughts focus on her neighbor downstairs, but then she quickly returns to the topic of the sofa and concludes her story in present tense, "Das Sofa liegt rücklings im Zimmer" (24).

There is a decisive rhetorical difference between the two types of past tense discourse - memory monologue and summary of recent action — and this difference is also reflected in the narrator's language. The narrator's memory monologues are usually triggered by association, and she often has recourse to metaphorical language. The flow of her sentences follows the free-flowing and subjective movement of thought. The retrospective summaries, in contrast, are written in the direct and unembellished language of reporting. Genette describes the rhetorical situation evoked by the temporal instability of such interpolated narrating as follows.

[T]he narrator is at one and the same time still a hero and already someone else: the events of the day are already in the past, and the "point of view" 
may have been modified since then; ..., and here focalization through the narrator is at the same time focalization through the hero. (Narrative Discourse, 218)

Such narrating, he adds, is often characterized by "an indefinite, even incoherent, temporal position"-a description that most accurately portrays the narrator's state of mind and her narrating in the Leipzig chapter (216). Indeed the following quotation from Genette describes quite poignantly the situation in the Leipzig chapter.

Finally, the extreme closeness of story to narrating produces []$, \ldots, a$ very subtle effect of friction (if I may call it that) between the slight temporal displacement of the narrative of events ("Here is what happened to me today") and the complete simultaneousness in the report of thoughts and feelings ("Here is what I think about it this evening"). (217/18)

"Friction," the sense of something not quite matching, is exactly what the reader experiences in the parts of the Leipzig chapter I referred to above as well as in the many other instances when past tense narration is not memory discourse. In Die Überfliegerin, this kind of idiosyncratic manipulation of narrative tense is the artistic representation of the narrator's conflicted relationship with time- of the way she is caught between the 'no longer' and the 'not yet.'

\section{Die Überfliegerin and Irony}

The one topic yet to be discussed is Krauß's use of irony, which is much more prevalent in Die Überfliegerin than in any other of her post-Wende works. One of the reasons for this is most likely the timing of its publication. By the mid-1990s, the initial 
excitement about reunification had waned, the newness was gone, and people had begun to see that there was a price to pay for their newly found freedom, a price in the form of new hardships and disappointments. At that time, the sense of shattered expectations and crushed hopes was freshest and most acute. Another reason was perhaps Krauß's own ambivalence and skepticism towards this changed reality. Furthermore, some of her irony could also have been aimed at her compatriots, at their gullibility and their willingness to let themselves be seduced by the empty promises of a Western life-style.

First, irony as part of Krauß's narrative method is most prevalent in the way she employs narrative tense in order to undermine the work's order of events and thus reveal the narrator's deep-seated sense of disintegration. Second, there is irony in Krauß's play with stereotypes when describing American and Russian culture. The narrator's report about her adventures in these two countries abounds with oversimplified notions and generalizations that are shared by many of Krauß's (East) German compatriots. David and Julie, the narrator's Minnesota hosts, for example, exhibit the naïve innocence and unwavering optimism that Americans are so well known for in the rest of the Western world. Representing the country's educated, pro-active, and liberal upper middleclass, the couple is an interesting mix of dreamy tree-huggers, belated hippies, health fanatics, and political activists. Lilly, the narrator's Madison hostess, embodies the idea of American mobility to an extreme; she is a doer and a workaholic who is always on the move. Lilly's explanation of how the narrator will get from Madison to her next destination, San Francisco, is a wonderful example of Krauß's play with stereotyping. Lilly explains, “[J]etzt gehst du den Mississippi abwärts, dann biegst du rechts ab, aber gib acht an den Kreuzungen: wer zuerst kommt, fährt zuerst, wer als Zweiter kommt, fährt als Zweiter 
und so fort, okay?" $(76)^{95}$ That the climax of this chapter is saved for last, for the narrator's visit to San Francisco, is no surprise because the city is famous for its liberalism. Here, the choices seem virtually unlimited and one can even choose one's gender. Concerning the many instances of comic exaggeration and Krauß's play with clichés in the Unted States chapter, Paul Michael Lützeler remarks that Krauß is not aiming at a realistic description of life in the United States, but rather, she wants to emphasize the stark contrast between the two worlds, of the GDR and the United States.

Es geht um die transrealistische Konfrontation krasser, teils ins Karikaturistische, teils ins Traumhafte transponierter Gegensätze. Dem Eingekerkertsein steht die Befreiung aus Kerkern, der Aggression die Freundlichkeit, dem Grau-in-Grau die Farbenvielfalt, der Ohnmacht die Tatenkraft, der Ratlosigkeit, die Entschlossenheit, der Enge die Weiter, .. . gegenüber, .... ("Vereinigung und Entropie. Der Schock einer Zeitenwende: Die Überfliegerin von Angela Krauß,” 148.)

But Russia, too, is the butt of Krauß's ironic humor. For instance, everyone in the West has heard horror stories about Eastern Europeans always having to stand in line. No surprise then that the narrator's very first experience after landing on Russian soil is waiting in line at customs. Last not least, Krauß pokes fun at the way in which, as a result of the East's Westernization, consumerism has conquered the communist capital, or to speak with Lützeler, "Moskau ist im Amerikafieber" (150). Toma's obsessive wheelings

${ }^{95}$ An added bonus in Lilly's description is the reference to the American institution of four-way stops, a totally alien concept to German drivers and therefore the horror of many a German driving in the United States. 
and dealings at the Moscow black market and the way she regards collecting stuff as a path to happiness are parodies of communism's colonization by capitalism.

One of the more obvious instances of Krauß directly criticizing the development in her own country is the portrayal of the Händsch couple, the narrator's Leipzig neighbors. Frau Händsch, who unlike the narrator belongs to the doers (the Tatmenschen), suffers from a head injury and the back of her head has been replaced by a piece of metal, we are told (43). It is certainly tempting to interpret the woman's head injury as an ironic reference to the Krauß's compatriots' having mindlessly and rashly fallen prey to the empty promises of Western capitalism. Frau Händsch and her husband ruthlessly take advantage of the narrator's helplessness and confusion and more or less coerce her into signing a life insurance contract. And it is certainly fitting that the narrator in her state of gradual dissolution and with her fear of chaos would be the perfect candidate for a business transaction such as this.

The narrative's title, Die Überfliegerin, is also ironic. As mentioned earlier, flying is the work's central motif, and it is directly related to the narrator's wish to overcome her fear of venturing out into the changed realities of the new East. The title could be a literal reference to the narrator's travels, her flying across the world, or as she puts it, from continent to continent, from East to West, to West, always westwards till the West suddenly became the East again..$^{96}$ In the context of the new East-West relationship after 1989, this rather unusual way in which the narrator describes the path of her travels refers to her realization of how after the Cold War, the world has changed and how the East is gradually becoming more and more like the West. But did the narrator really embark on

96 “[V]on Kontinent zu Kontinent, von Osten nach Westen, nach Westen, solange nach Westen, bis der Westen plötzlich wieder Osten war" (96). 
these two rather unusual journeys? Probably not, and this, I think, is the greatest irony of the narrative. Since in German the verb "überfliegen" can also mean to scan, it is quite likely that the woman was just imagining her bizarre adventures while hiding in the basement. She only wishes she had the courage to venture out of the confined space of her old identity, to shed her former self, and to interact with the world that is waiting outside. It is only in her mind that she is able to enjoy her newly found freedom while in reality, she is still paralyzed by her fear of the unknown. When discussing the importance of the travel theme in post-unification East German literature, Elizabeth Mittman notes that

[e]xperiments in travel offer [ ] authors an imaginative space in which to shape their responses to the extreme psychic dislocation of German unification, and their interaction with sites of cultural otherness reveals a refunctioning of elements in the construction of new grids of meaning. ("On the Road to Nowehere: Utopian Geography in Post-Unification Literature," 352)

In the case of Krauß's protagonist, this process is presented merely as a hope, as a state of mind that the narrator is aspiring to reach some day in the future, and thus only emphasizes the severity of the narrator's sense of dislocation.

I shall save my remarks about the notion of Weiterschreiben in Die Überfliegerin for the chapter's concluding section, but before moving on to my discussion of Weggeküsst, I want to emphasize one last time how in form and content Die $\ddot{U}$ berfliegerin is a product of the historical and political context within which it was created. In this text, Krauß gives artistic shape to the state of mind of a whole country, the 
GDR, during the lengthy and often painful process of social and political reconstruction. As pointed out by Lützeler, “[die] Erzählung lebt aus den historischen Erfahrungen der Umbrüche und Veränderungen in der DDR.” At the same time, the places that the reader is taken cannot be found in a travel guide; they are to be discovered only in the human psyche - "Orte, die in der menschlichen Psyche lokalisierbar sind" (154). Nowhere else in the Western hemisphere during 1990s was there a place where the break between past and present and the awareness of a life suddenly and forever lost was as dramatic and as all-embracing as in Germany's New East. ${ }^{97}$ Capturing the spirit of this historical moment is the most important feature of the GDR-ness in Die Überfliegerin.

\section{Weggeküsst. “. . . um uns unseres eigenen Rätsels zu versichern”98}

Weggeküsst is a continuation of Die Überfliegerin for a variety of reasons. Seven years have passed since the events described in Die Überfliegerin, but even in this later work, the narrator-protagonist is still struggling to adjust and find her place in the Westernized East. In fact, the anonymous narrator in this later work seems like an older self of the protagonist in Die Überfliegerin. Her monologues reveal the same poetic sensitivity towards the world around her, and more importantly, she is dealing with some of the same issues and conflicts that caused her emotional crisis in the earlier narrative. Though she still has the same curiosity for life and people as in Die Überfliegerin, her enthusiasm is now dampened by a deep sense of disorientation. She is overwhelmed by

\footnotetext{
${ }^{97}$ Of course, the GDR was not the only eastern European country whose social and political reality underwent major changes after the end of the Cold War, but the GDR is an exceptional case because of its former Western twin. Unification with this Western counterpart made the country's Westernization speedier and more radical than in the rest of the East.

${ }^{98}$ Die Gesamtliebe und die Einzelliebe, 96.
} 
life, suffers from over-stimulation, and is in constant danger of losing herself. To avoid being consumed-weggeküsst-by the incessant flood of new impressions that are bombarding her senses, the narrator's life moves in small circles only. Though she has now mustered the courage to leave her room, she is still afraid of being overwhelmed by chaos. Her days follow the same routine, and she spends much of her time in the isolation of her own thoughts. ${ }^{99}$ Playing the role of an observer rather than a participant is another quality that connects her with her earlier self. While she is paralyzed by the abundance of choices, the world seems to be running away from her as she cannot keep up with the speed with which it is changing.

\section{A. Composition and Structure}

Much of my discussion of Krauß's Die Überfliegerin dealt with the work's fragmented structure, and fragmentation is also one of the defining characteristics of this later text. The narrative consists of eight short, relatively independent textual units or chapters, each of which is defined by its own compositional characteristics. As the narrative progresses, however, a tightly knit web of interconnected images and themes emerges and provides a sense of unity and focus to the otherwise rather fragmented

${ }^{99}$ Among the many possible interpretations of the work's unusual title, I find relating it to the fairy-tale topos of the magic kiss a very appropriate approach, especially since the book's final scene very much has the ring of a fairy-tale. Wegkiussen, being kissed away, calls to mind tales such as Sleeping Beauty or The Frog Prince. Not only does the title's playfulness allude to the highly imaginative, elusive, and dream-like quality of the narrative itself, but there is also a deeper meaning to this fairy-tale motif. Usually the kiss is an instrument of transformation. In The Frog Prince, the kiss of the princess changes the ugly frog into a beautiful prince, and in Sleeping Beauty, the prince's kiss frees the princess from the evil spell. In Weggeküsst, however, Krauß playfully subverts the magical power of the kiss. The kiss (the sheer unlimited wealth and abundance of the world), instead of being an instrument of liberation, now is all consuming and threatens to suffocate the narrator's sense of selfhood. 
composition. It is difficult to assign the text to a specific genre. It is a kaleidoscope of different kinds of discourses. It is part expository writing and part narrative; some sections read like theater scripts while others are highly lyrical.

The book starts with a brief retrospective description of what later turns out to be a typical morning in the narrator's life. A short while ago- "kürzlich," the narrator says - she woke up to a world that seemed the same but in reality was strangely different. Now, when she leaves her room, her whole being is taken over by a feeling of loss and disorientation. Being acutely aware of how everything she sees begs for her attention and threatens to "kiss her away," she walks towards her destination, the coffee bar Sweetie. She briefly looks around, tries to read her neighbor's newspaper, and then begins a brief conversation with the man next to her.

In chapter two, the narrator briefly interrupts her story and explains her repeated visits to the nearby zoo. Whenever she feels she has reached the point when nothing makes sense to her anymore - “den Punkt der allumfassenden und tiefen Verständnislosigkeit" - she escapes to the zoo (23). Being with the animals makes her forget how busy, hurried, and distracted life has become and reminds her of a simpler kind of existence, one where there is no need to explain.

In chapter three, we are back at the coffee bar. "Heute ist ein neuer Tag," the narrator announces but immediately asks for yesterday's newspaper (29). The present is too much for her to handle, she laconically states. She simply cannot keep up with the fast pace of change. Then the narrator occupies herself with conjectures about Nette, the waitress at the coffee bar who, unlike her, has been able to keep up with the times. She then thinks about some of the recent changes in her immediate environment and reflects 
upon her current emotional crisis. Finally, she avoids the present altogether and escapes into reminiscences about her life immediately after the Fall of the Wall-about a time when everyone, including she, was filled with the excitement of change and the prospect of building a new future.

Chapter four is basically a continuation of the previous chapter. It is now understood that the woman spends most of her days eating sweets, trying to decide what to do with her life, and reminiscing about a time when she knew what to expect from life.

In chapter five, time suddenly speeds up. It is now evening and late summer has turned into fall. Not a time to make decisions, the woman announces. Following the stream of people returning home from work, she is reminded of how she, like so many others, is drifting aimlessly through life. "Ich bin eine unter Millionen, die auch nicht wissen wohin," she tells herself (65). Once again, the past is intruding upon the present, but this time in the shape of the Konditormeisterin, the owner of the former Konditorei Goldschmitter, which was converted into the shiny, modernized coffee bar Sweetie. Thinking of the older woman as an ally and soul mate (both are specialists in relationships), the narrator seeks her advice, mentioning that she is suffering from neglect and gradual disintegration. But the older woman shows no understanding or sympathy for her situation and simply walks away.

Chapter six opens with the words, "Einst war ich stark, barfuß, und frei: ein Vorschulkind" (77). The narrator's thoughts are now traveling back to her childhood. She talks about her friendship with Tine (whose name had already been mentioned repeatedly) and their carefree play on top of the wall that surrounded their courtyard. In fact, this scene of the narrator and her friends running across the metal top of the wall, the 
sound of their feet echoing through the neighborhood, is one of the central motifs in the narrative. This was a time in her life when she was filled with a sense of complete freedom, when she felt invincible, and when she still believed in her own uniqueness. As we turn to chapter seven, it first appears as if we were circling back to the beginning of the narrative. We are again in the woman's room at the moment she wakes up, and as in chapter one, she mentions her sense of disorientation and alienation. But the similarity is superficial. For one, the narrator now seems more aware of how she has been whiling away her time and isolating herself. This is not the only a difference, however. Soon unexpected things begin to happen ${ }^{100}$ Mark, a communication specialist and an old acquaintance, invites her to meet with him and explore a unique professional opportunity. On her way to see him, she runs into the stranger she had met at Sweetie weeks ago, and they plan to visit the zoo later that evening. The chapter ends with a longish description of Mark's speech about the revolutionizing powers of the communication network, which seems to reawaken the narrator's interest in life. Gradually things begin to fall in place, and not just in the narrator's life. In the narrative, too, there is a noticeable shift from thought to action. Certain central ideas and images from previous chapters reappear and together give meaning to what otherwise would remain random.

${ }^{100}$ The perceptive reader will quickly pick up on the different cues that announce this change long before it actually materializes. Even more telling is her description of what goes on in her mind as she watches the two men in a red bucket truck. Seeing the men work high up in the trees and exchanging casual glances with them evokes in her a kind of epiphany. She is transposed into "eine Art Wachtraum, eine glückliche Benommenheit," so she explains, and she feels how the reawakening of her curiosity in people, her "Entfaltungswunsch," (87). She also suddenly notices the atmosphere of abandonment - "die Verlassenheit" - that is pervading her rooms. "Wo war ich in den letzten Jahren zu Hause?" she wonders and then walks through her apartment, as if she were saying good-bye. (Saying good-bye to her old life, perhaps?) All of these subtle implications combined with the re-appearance of the silent stranger and the mysterious letter from chapter one allude to some impending change. 
While the second to last chapter takes us back to the very beginning of the narrative, the last chapter in Weggeküsst is linked to chapter two. The narrator is back at the zoo. But again the impression of sameness is deceptive. The woman now enters the gate to the zoo, "taumelnd," dizzy (from excitement about the meeting she just attended, we may assume) and she exudes positive energy. Today's visit has a different purpose than usual. This time, she is here not to escape from life's unbearable pressures. Instead she has arranged to meet someone who, as we learned in the previous chapter, seems to understand her situation and who shares her sensibility. The chapter, and with it the narrative, ends with a simple but deeply poetic scene-a significant moment - of the narrator and her companion standing by the lions' enclosure listening in the dark to the sounds of the animals.

Not a lot and certainly nothing exceptional happens in Weggeküsst, but the narrator's active imagination and her ever-changing thoughts compensate for the lack of external action. In Die Überfliegerin the plot was largely driven by the narratorprotagonist's Aufbruchsstimmung - her longing to explore the world from which she had been shutting herself away-whereas, in Weggeküsst, the exact opposite is the case. The narrator's movements are confined to her Leipzig neighborhood, and she divides her days between her apartment, her favorite coffee bar Sweetie, and an occasional visit to the zoo. In reality, her participation in life is only an empty gesture. She still seems paralyzed by her fear of chaos. Days and weeks go by, but nothing really happens.

Location and the change of location is an important structural device in Weggeküsst, and Krauß connects with each place certain important themes and motifs that reveal specific aspects of the narrator's inner conflict. In the isolation of her 
apartment, the place she identifies with most, the narrator ponders the emotional and psychological effects of the various changes in her environment. The coffee bar, where she seems to spend most of her days, represents her inner stagnation and the repetitiveness of her days. It is here that we get to see most clearly her paralysis. The zoo is her sanctuary and refuge where she can escape from life's complexities and its challenges and demands. The fact that the narrator's movements are limited to just a few places, that she keeps thinking the same thoughts, and is engaged in the same conversations is an instantiation of her being trapped in the vicious cycle of her fears and worries.

That Weggeküsst tells a typical GDR/new East story almost needs no further comment. The narrator's emotional and psychological conflicts - the way she feels lost in time and her sense of disorientation and paralysis - are, as is commonly known, feelings that many East Germans experienced during the post-Wende era, and more importantly, they are a uniquely East German phenomenon. Once the excitement about the Fall of the Wall and the newly gained freedom had worn off and reality had begun to settle in, many East Germans became disillusioned and felt out of place. They became increasingly more aware of what they were lacking in this new life. Also, like the narrator in Weggeküsst, many did not know how to use their freedom productively and take responsibility for their own lives.

\section{B. Story Time and Temporal Structure}

Time is one of the main topics in Weggeküsst, just as time is of unique importance in the post-reunification East. The narrator is still experiencing the same kind of 
diconnectedness from time as in the earlier work, and the knowledge of time passing is an important part of her existential crisis. As she is constantly confronted with the knowledge that she is out of touch with time, time takes on a special importance, both as a central theme and as a structural device.

The narrative's rather idiosyncratic temporal structure is a direct result of the narrator's efforts to reorient herself in a world that is so completely different from the one she knew before. The story proper of Weggeküsst covers several weeks between late August and late September of 2001, but since the narrative is delivered as a monologue and since thus much of its action happens exclusively in the narrator's mind, the span of time covered by the narrator's thoughts is equally important. While the one crucial childhood memory the woman repeatedly refers to goes back to the first decade or so of the socialist GDR, most of the remembered scenes are from immediately after reunification. The contrast between how life was then, in the years directly following the Wende, and how it is now, almost a decade later, is one of the main sources for the narrator's sense of alienation. Twelve years have passed since the historical turn, but she is still struggling to adjust to the changes and find a new beginning. Years ago, so she announces at one point of her story, she was thrown off of the "kurz schlingernde Zug der Zeit," and as with each passing year her disillusionment increases, getting back on is becoming increasingly more difficult (41).

The narrator's conflicted relationship to time is also a result of her inability to let go of the past-a problem she was already struggling with in Die Überfliegerin. For her, the present always also includes experiences and impressions from the recent as well as the more distant past. This recent past-the "damals" she so frequently mentions - are 
the years of the "Umbruch" immediately after the Fall of the Wall. It was a time when everyone was filled with excitement about their newly acquired freedom and hoped for a better future. Then there is also the distant past of her childhood and in particular the memory of her friendship with Tine. This event belongs to a different historical time altogether, indeed a truly different life, because the social and political reality that forms the background of this childhood memory has forever been erased. Thematically the narrator's sense of displacement is reflected in the many digressions into memory. Structurally, this feeling of being out of time finds its realization in the ambiguous temporal relationship between the different segments of the narrative.

Since the narrator is so deeply immersed in the world of her thoughts, her references to time passing are highly subjective. The temporal markers she uses, such as "kürzlich," "heute," "gegen acht Uhr abends," or "inzwischen ist es Herbst," may seem specific at first, but aside from signaling the passing of time - which is their purpose on the story level-on a deeper level (as I will show in the following pages), they come to represent the repetitiveness in the woman's life. Especially in the work's first six chapters, the temporal expressions signify stagnation rather than progress.

Weggeküsst begins one morning with the narrator's first thoughts after awakening. Then we accompany her on her short walk to the coffee bar. She exchanges a few words with a man sitting across from her, he leaves, and the story is interrupted. Not much time has passed. Chapter two consists primarily of reflective discourse and thus is located outside the temporal framework of the narrative's plot in the eternal present of the narrator's thoughts. At the beginning of chapter three, we are back at the coffee bar, but as implied in Nette's remarks about the stranger from the first chapter, it is now a day 
later. The chapter consists almost exclusively of the narrator's interior monologue, and as we follow the movement of her thoughts, real time seems to stand still.

The narrator's remark to herself, "Was tust du eigentlich hier? frage ich mich ein Dutzend Jahre später," at the beginning of chapter four, at first seems like a continuation of her reminiscences from the previous chapter, but when the narrator is again asking for yesterday's newspaper and when Nette once again inquires about the silent stranger, we come to realize that these words must be part of a different, yet similar, set of thoughts the same conversation, the same thoughts, but on a different day. We know that time must have passed, but we don't know how much. And it is even more disconcerting that although days must have gone by, nothing has happened and nothing has changed. Suddenly, the narrator soon announces, "Es ist dunkel geworden und ich sitze noch immer hier," and then continues with her reflections, contemplations, and reminiscences without showing any concern about the passing of time (52).

As we turn to chapter five, time has sped up even more. It is still evening, but now late summer has turned into fall. Where did the time go? This rather idiosyncratic manipulation of story time in the first five chapters of Weggeküsst-their metaphorical compression into one long day and the simultaneous fast-forwarding - speaks of a mind torn by conflict and marked by loss of direction. It is indicative of the narrator's inability to deal with the passing of time, which ultimately has resulted in stagnation. At this particular point in her life, when she cannot yet imagine a future and when the old life no longer exists, her days consist of interminable sameness.

As if to counterbalance the sudden jumping ahead and fast-forwarding of time, the narrator, in the next chapter (chapter six), leaves the present altogether and lets her 
thoughts journey back to the days of her childhood. This chapter marks a point of transition. At the beginning of chapter seven, it first seems as if the narrator were returning once again to the beginning of her story and to another description of the sameness of her days. But there are some distinct differences from the earlier chapter, and most importantly, there is a noticeable change in the narrator's monologue. Rather than reporting her thoughts, as she usually does, she now describes action. As in the narrative's last two chapters, the focus shifts to the narrating of action and the work's temporal structure becomes more regular. It is now defined by the narrator's actions rather than her thoughts.

What has been emerging is an unusual structural pattern that leads to an interesting paradox: Although they cover several weeks of story time, the first five chapters actually describe only a single day in the narrator's life - a day that is representative of the interminable sameness of the narrator's current existence. Time in these chapters is moving forward while simulataneously also standing still. In the last two chapters, however, the cycle of sameness is finally broken. Time now is moving ahead towards a future.

\section{Narrative Method}

In the previous section I discussed how Krauß uses narrative time as a means of foregrounding the narrator-protagonist's sense of displacement. Next, shall look at how with her use of different types of discourse and her manipulation of narrative tense, Krauß further supports the notion of the narrator's sense of displacement and inner fragmentation. A close analysis of the work's first chapter will show how the intricate 
interplay of different discourses reveals the depth and the complexity of the narratorprotagonist's inner conflict. I shall then proceed to discuss some of the more important structural peculiarities in the remaining parts of the narrative while paying special attention to the work's final two chapters. The intention is to show how Krauß's narrating is as important for producing the work's meaning as are the narrator's thoughts and actions.

As in Die Überfliegerin, Krauß's narrative method in Weggeküsst is unconventional and highly idiosyncratic. When asked about her unusual style of writing, Krauß explained in a conversation with Jörg Magenau, "Ich beschreibe Gefühle nicht, ich stelle sie dar. Für mich schließt das eine das andere aus. Das Darstellen ist unbarmherziger" (III). This focus on presentation (Darstellen), on implying ideas and concepts through the manipulation of the text itself rather than by directly describing them, is the essence of Krauß's narrative method, and it is also the reason why her texts are so challenging to read. As described above, one way in which Krauß realizes this goal of Darstellen in Weggeküsst is through her play with story time and the narrative's temporal structure; another way is by means of internal focalization and interior monologue. Using present-tense monologue and interspersing it with occasional recollections, Krauß manages to present events and thoughts with an uncompromising immediacy at the moment when they occur. This way, the act of narrating itself - the structure of the narrative as well as the different discourses employed-becomes instrumental in the creation of meaning. 
Weggeküsst opens with an anonymous, female, first-person narrator relating in

free indirect discourse her strange sensations upon waking up one morning not very long ago.

Kürzlich wachte ich auf und merkte, noch im Liegen, daß etwas geschehen war. Vorsichtig, ohne mich zu rühren, tastete ich mit halbgeschlossenen Augen meine Umgebung ab. (9)

The similarity to the first sentence of Kafka's Metamporphosis is deliberate and also ironic because, as we are about to find out, in Krauß's narrative it is not the protagonist who wakes up changed, but the world around her. In addition, there is also a striking similarity to the beginning of Die Überfliegerin. In the earlier text, the narrator stands at her window, scans the only too familiar sight of the Leipzig train station below her window, and then laconically remarks, "[U]nd das alles steht in einer fremden Welt" (10). ${ }^{101}$ Important about the beginning of Weggeküsst is also the fact that the story begins with an analepsis, an important narrative move with which Krauß establishes the

${ }^{101}$ But even more noticeable is how this first scene echoes the beginning of one of Krauß's earlier narratives, "Ströme," from the collection Glashaus. Just like Weggeküsst, "Ströme" begins with a description of the first moments of waking up in a room, but there are some decisive differences in these women's state of mind, which are related the historical situation at the time these works were published-GDR vs post-Wende East. The short piece begins as follows: "Heute morgen war ich sekundenlang dem Gefühl uneingeschränkter Bewegungsfreiheit ausgesetzt. Im Moment des Erwachens wurde ich ausgeworfen, hinausgeschleudert, ich trudelte orientierungslos in einem Raum, in einer Art Kasten, in dem zunächst nichts war, bis ich, halbblind vor Schwindel und Angst, die Strukturen meines bis zum heutigen Tag gelebten Lebens schemenhaft wahrnahm" (5). Unfortunately, this initial experience of just being and of having unlimited options vanishes as soon as the narrator 'identified herself.' The realization of being limited by who she is and a general sense of constraint leave the woman disappointed and paralyzed. Interestingly, the narrator in this earlier story is plagued by exactly the opposite problem as the woman in Weggeküsst. The narrator in Weggeküsst is able to enjoy the freedoms that the woman "Ströme" is longing for, but the world changed too much and too quickly. Ironically, she now wishes for exactly that which the narrator in the earlier story experienced as confining - the sense that everything has its place, including her. 
significance of the past in the narrator's current life. Striking is also the narrator's use of personification when she reports that upon her waking all the objects were still in the same place as they were when she left them the night before. All my belongings stood as usual around my bed, she reports. The narrator's use of "stood around" ("standen herum") is unusual. People stand around; furniture simply stands. In other words, she used to think of her possessions as being assembled around her, being her audience and watching her sleep. But now not a single one of these objects - mirror, chair, clothes, chest of drawers-looked at her. ("Nur schaute mich keines mehr an.”) The audience metaphor and with it the personification of the objects in her room continued also into the next paragraph, which because of its ironic humor, is too entertaining not to be cited in some detail.

Solange ich denken kann, erwache ich morgens in eine Welt, die auf mich wartet. Die Tiere rufen und schreien. Der Schrank, verschlossen und beherrscht, wartet auf mich. Der Stuhl steht mit vor Ungeduld vibrierenden Beinen da, ... Die Wâsche, die Strümpfe, die Kleider warten auf mich, die ich ihr Inhalt bin.

And quickly shifting back to past tense narration, she announces, "Und plötzlich, von heut auf morgen, hatten sie damit aufgehört. (9)

The unique effect of this passage is created by Krauß's figurative language in which the objects in the room express the emotions - the excitement and anticipationthat the narrator herself used to feel when first waking up to the world. The narrator presents us with a fairytale world in which she experiences a deep connectedness with the world around her. Now, however, on this particular morning, the feeling of harmony has 
been replaced by a deep sense of estrangement and alienation. This we find out not by the narrator telling us about her feelings but, as before, through the narrating itself - through the abrupt shift from figurative language to factual description. The magic that used to fill the room is gone. The formerly so familiar possessions are now simply unexpected appearances (“[u]nerwartete Erscheinungen”) that could at the most be called objects ("Gegenstände"), the narrator reports. They may as well stand on their head, she declares laconically, or at any moment form themselves into random chains of molecules. How does she react to this sudden transformation? "Ich setzte mich lange diesem unvertrauten Zustand aus," she explains, but with no result - "Ohne Ergebnis" (10). Once again, the narrator's choice of words is significant. The reflexive verb - "sich aussetzen;" exposing oneself to-implies passivity, and thus it reflects the sense of paralysis that defines her new reality.

In the second section of the chapter, the narrator interrupts her retrospective reporting and switches to present tense monologue. She is now beginning with her story, at least so it seems. "Ich kann mich nicht beklagen, "she reports, "Auf dem kurzen Weg zum Frühstück bei Sweetie lacht man mir schon entgegen und will mich küssen” (10). Gradually though, what at first seems a description of this particular morning takes on a slightly different meaning. The reader begins to realize that these sentences are not describing a singular event but, instead, depict the woman's daily ritual. ${ }^{102}$ Every time she

${ }^{102}$ Genette's concept of frequency as laid out in his Narrative Discourse is particularly useful for analyzing Krauß's narrative method in Weggeküsst. Narrative frequency, according to Genette, has to do with how often a specific part of the story (diegesis) is repeated in the narrative. Accordingly, he distinguishes between "four virtual types:" Singulative narrative, which actually includes two different situations: "narrating once what happened once" (1) and "narrating $n$ times what happened $n$ times" (2). Important in both cases is the equality of the numbers on both sides of the equation. The 
leaves her house, so the narrator tells us, she enters a world that with its flood of new impressions and its overwhelming plenty threatens to consume her. Together with the previous, retrospective passage, this kind of synthetic narrating emphasizes habit and repetition rather than singular action, and it thus prepares us for what is gradually being developed into one of the work's major themes - the narrator's inability to take action. Wondering how she will ever be able to deal with all the changes in her environment and in her life, the woman remembers a scene from earlier when she left her house-her encounter with a new mail carrier-and promptly she switches to past-tense, retrospective narration. Her interest in mailmen, so she tells us, is part of her general fascination with people. As soon as she meets someone, she feels an irresistible urge to integrate this person into her own life.

With the statement, "Wenn ich traumlos geschlafen habe," the narrator interrupts her retrospective monologue and then returns to her previous topic-how in the mornings she is alive with curiosity but then she quickly loses interest. This is not how things used to be, however, and not without a touch of melancholy, she recalls how in the past, she was eager to partake in the lives of the people she met, she saw, or even just heard about. Long ago, her goal was to make the world her own, to keep building the web of her desires ("Netz meines Verlangens"), as she calls it,

third type is repeating narrative (narrating " $n$ times what happened once"), and last Genette mentions iterative narrative, which means narrating "once what happened $n$ times" (114). We can recognize iterative narration by temporal expressions such as, "always," "usually," or "every day," as well as by context. In the text passage I am referring to, indicators of iterative narrative are the "am Morgen" in the third sentence, "ich brauche immer eine gewisse Zeit am Morgen, um zu begreifen, wo ich bin" (10, my emphasis) as well as the temporal expressions "immer" (10) and "gewöhnlich" (11). 
So far, in these first three sections of the chapter, action has been almost exclusively internal and has been the product of the narrator's roaming thoughts. Furthermore, the few moments of external action turned out to be mostly iterative, or at least only ambiguously singulative.

The fourth section begins with the narrator's announcement, "Bei Sweetie ist es gewöhnlich voll" (13). The "gewöhnlich" immediately signals iterative discourse, and so does the narrator's description of the ways in which people at Sweetie go about avoiding one another day after day. Then she talks about the things she does after entering the coffee bar-she looks around, takes a quick look at herself in the mirror, and then focuses on her neighbor's newspaper-and it seems as if something like an external action, i.e., singulative narration, is beginning to develop. But some parts of her account, for example her description of what she generally does when she arrives at Sweetie, are unequivocally iterative. This tension between iterative and singulative narration in the narrator's monologue reflects the severity of her confusion. More importantly, though, it is a sign of how she lost her sense of time and how days and weeks simply merge into one. Even the narrator's concluding thought, "Ich gebe nicht auf," is ambiguous because the determination of its frequency could be iterative as well as singulative (15). As iterative statement its message could be that all these years she has never completely given up trying to redirect her life. As a singulative statement, it could be read as an announcement that she is about to change her ways..$^{103}$

${ }^{103}$ The narrator's "Ich gebe nicht auf" also announces the central idea of the whole narrative. Although the woman claims that she has lost interest in other people's lives, she keeps trying to reach out to others and to connect with them. This love for people and her curiosity about life in general, so she repeatedly tells us, is part of who she is. 
The temporal marker and explicit ellipsis, "Frage ich mich fünf Minuten später," at the beginning of the next section, reminds us that while the narrator is engaged in her contemplations and recollections, real time is moving forward (15). ${ }^{104}$ Aware of how much she feels out of place, but at the same time remembering that she is not willing to give up her interest in people, the narrator starts watching the other customers. Soon a man sitting across from her and reading a newspaper catches her attention. She quickly makes a series of conjectures about this man's life while trying to read his newspaper. The section ends with a continuation of what has been emerging as the first signs of external action: her neighbor, noticing her interest, offers her his newspaper and they start a conversation.

The narrator's, "Okay, Okay" - yet another ellipsis — at the start of the chapter's final section introduces a decisive change in narrative strategy from interior monologue to present-tense reported dialogue. This last section of the chapter is a transcript of the conversation between the narrator and her neighbor from the other table. But it is a conversation in appearance only. In reality it is just the narrator who is speaking, or rather, it is a stream-of-consciousness-like rambling with which she is desperately trying to catch her neighbor's attention. With this change of narrative method from a direct

${ }^{104}$ The idea of explicit ellipsis I am taking from Genette's Narrative Discourse, where ellipsis is one of the four major narrative movements (the others being descriptive pause, scene, and summary). In general, Genette speaks of ellipses "where a nonexistent section of narrative corresponds to some duration of story" (93). An ellipsis can be either explicit, in which case the story time that passed is indicated in the text, or implicit, when its "presence is not announced in the text" but is noticeable only because there is "some chronological lacuna or gap in narrative continuity," (108) or it can be hypothetical, which is "impossible to locate" and is revealed only retrospectively (109). Genette's system for analyzing the various relations between the time of the story and the (pseudo-) time of the narrative is a particularly helpful tool for analyzing Krauß' narrative method in Weggeküsst. 
representation of the protagonist's thoughts to narration of dialogue, Krauß now incorporates dramatic discourse into the narrative. As a result, the few interpolated sentences of present-tense narration with which the woman describes her neighbor's reactions function like stage directions in a drama, and they heighten the theatrical quality of the scene. The narrator's monologue, which is now addressed to an, albeit silent, other brings to the fore one of the most important aspects of the narrator's current crisis: her emotional isolation and resulting inability to establish contact with another person.

Having reached the end of the narrative's first chapter, we have come to see the beginning of not just one but two stories. On the one hand, there is the story of the narrator's thoughts - of her reflections, observations, and recollections - which establish the narrative's internal action. It shows the narrator's emotional and existential crisis and reveals the different aspects of her inner conflict. These exclusively verbal events happen only in the narrator's mind, and they represent a type of narrating for which Genette has coined the term "narrative of words" (Narrative Discourse, 169). On the other hand, while she is contemplating her current situation, the narrator also participates in external action. She gets up and walks to the coffee bar, she watches people and talks to the man across the table from her. These actions mark the beginning of the narrative's external plot - the "narrative of events." At the same time, action, however minimal it may be, is contaminated by the iterative so that there is almost no progression in the plot. In other words, the kind of discourse alone conveys one of the central problems of the narrator's current situation - stagnation.

In the work's first six chapters, this emphasis on internal action prevails. We find the same mixture of reflective and contemplative passages and of lengthy recollections, 
with very little narration of event. In these chapters, it is especially the different dramatic scenes - the various short dialogues between the narrator and Nette and her conversation with the Konditormeisterin in chapter five-which catch the reader's attention. These dialogues, in which the narrator now explains to another person what she feels and why she is afraid to act, are essential to our understanding of the woman's emotional state. (Especially enlightening are the conversations with Nette who, unlike the narrator, is a pragmatist and a doer, and who keeps challenging the narrator's unwillingness to take charge of her life.) Considering the narrator's state of mind, it is quite fitting that in the work's first six chapters, it is her circling thoughts - all of which in some way relate to her inability to act - and not her actions that drive the narrative forward.

Chapters two and six, as mentioned earlier, are not part of the story proper, but both are crucial for the development of the narrator's inner conflict and thus play an important role in the narrative's internal plot. These chapters help illuminate the narrator's psychological state. They reveal her melancholy longing for a simpler and purer kind of life, a life free from the complexities and disappointments that are now the cause of her paralysis, and they give us insight into the different motivations behind her thoughts and actions.

More significant, however, are the changes in narrative method in chapters seven and eight, when external action speeds up and the plot begins to thicken. And as before, this change in focus from internal to external is reflected in Krauß's narrative strategy. Summary and scene are now the two dominant methods of narration, and narration proper is taking center stage. There is considerably less narration of thought; furthermore, the narrator now focuses on the current situation, and her thoughts are indicative of a change 
in her emotional state, which is perhaps only temporary but nonetheless significant.

Furthermore, in these final two chapters, all of the crucial events are presented as dramatic scenes, either in reported or narrated dialogue. Since these "scenes" provide important insight into the changes in the narrator's attitude, they deserve closer attention.

The two dialogues between the narrator and the stranger from the coffee bar in chapters seven and eight are both delivered in present-tense reported speech. Krauß is aiming for dramatic effect here as a means of emphasizing the unique importance of each situation. Had she had her narrator simply summarize these two conversations, they would have lost their immediacy and their drama and thus would have had less impact on the reader. Krauß now literally has these moments in the narrative speak for themselves since all we are given in these scenes are the spoken words, no descriptive or interpretative detail. Instead of telling us what is going on in each character's mind, Krauß has us infer from certain recurring images and motifs the implication of what is being said. In other words, she directs our attention away from the actual text to the subtext and has us read between the lines. ${ }^{105}$

But not all dramatic scenes in Weggeküsst are narrated as present-tense reported dialogue. In chapter seven, for example, Krauß has the narrator deliver Mark's speech, a crucial scene for the narrator's emotional development, as past-tense narrated dialogue. This tense shift is unexpected, especially since the scene seems to be part of the

${ }^{105}$ This kind of play with text and subtext is, as we already saw in Hensel's Gipshut, integral to the ironic method of narrating, where language works on several levels. The idea of hiding behind one's words is further emphasized by the brevity and monotony of the narrator's responses. She generally answers in short, simple statements whereas her partner's speech is slightly more wordy and elaborate. 
narrative's present-tense action. How then, are we supposed to interpret this inconsistency?

Before answering this question, I want to refer to an instance in chapter four of Weggeküsst, when Krauß has her narrator engage in a similarly unexpected change to past tense, this time even in mid-dialogue during one of her many conversations with Nette. In both cases, however, Krauß provides a visual marker, a major paragraph break, right before the shift to retrospective presentation. These empty spaces in the text are one of the trademarks of Krauß's style. They are signposts that help the reader navigate among the many changes in the narrative's direction, and they are the visual representation of things not connecting, of something having been left out. In the two passages I am referring to, the source of the disruption is in the narrator's mind and the paragraph break signals a change in the narrator's thoughts rather than a change in plot. In both instances then, the tense shift that accompanies the empty line in the text signifies some internal rupture, and thus it alerts the reader to the special importance of what is about to follow.

Chapter four, just like the rest of the core chapters, is primarily about the narrator's inability to change her life and further develops the theme of repetitiveness. We learned how the narrator spends her days following the same routine, how she talks to the same people about the same topics, and how her thoughts keep revolving around the same issues. Her conversations, too, seem to repeat themselves. One other idiosyncrasy we discovered is how she keeps evoking the past as a means of better understanding the present. With this in mind, I am suggesting that the shift to past-tense narrated speech during her conversation with Nette marks one of these instances where in the narrator's 
consciousness past and present have become interchangeable. Nette's admonitions evoke in the narrator's already conflicted mind similar conversations from the past. This idea of confusing past and present is also reflected in the narrator's language, in the ambiguous temporal marker "then" (dann) in the sentence that indicates the moment of transition from present to past tense, "Du warst schon mal besser, hat [Nette] dann noch zu mir gesagt" (my emphasis, 49). This dann could mean then in the sense of next, in which case it would directly refer to the ongoing conversation, but it could mean at that time, and would thus refer to an earlier conversation. I see this shift to retrospective narration as representing a moment of mental short-circuiting. It signifies the instance when, in the narrator's mind, the present is being absorbed by the past, when the then and the now have become interchangeable. ${ }^{106}$

In chapter seven the situation is not as clearly definable. Apart from the extra spacing, there is no temporal marker to guide our reading, and nothing indicates that the narrator might have encountered a similar situation at some earlier point in time. ${ }^{107}$ Moreover, in these later chapters of Weggeküsst, the past is considerably less important. The narrator is now predominantly preoccupied with the present, with her new acquaintance, and with the prospect of change. All of these facts indicate that this second

${ }^{106}$ This tense shift also exemplifies a very interesting narratological phenomenon. It marks a moment when singulative narration - the narrator's current conversation with Nette-is suddenly contaminated by the iterative - her memory of all previous conversations. Such a contamination, according to Genette, is usually accompanied by a change in narrative tense from the present to the imparfait.

${ }^{107}$ Although in chapter three the narrator mentions an earlier encounter with Mark, possibly as much as a decade ago, there are no references to any commonalities between these two events, which eliminates the possibility that this scene represents a fusion of past and present experience similar to the one just described. 
shift from reported to retrospectively narrated dialogue is differently motivated than the one in chapter four.

In fact, I am suggesting that the tense change in chapter seven is identical to the temporal inconsistencies I discussed in my analysis of narrative strategies in Die Überfliegerin. There I interpreted the tense change as marking that moment when the narrator suddenly distances herself from her story and shifts from being a participant to being an observer. The same happens in the depiction of Mark's speech in Weggeküsst. Here, too, the change to past-tense narration of Mark's speech signifies a moment of distancing as it emphasizes the narrated-ness of the situation. But why would the narrator suddenly want to distance herself from an event that at the same time seems to fill her with excitement and new enthusiasm? Perhaps this change in the temporal determination of her monologue is Krauß's way of hinting at the narrator's lingering skepticism towards Mark's promises. On the one hand, she wants to believe in Mark's promises of a better future and she wants to be excited about life again. All of these positive feelings are expressed in her memory of Tine and the wall. On the other hand, she may realize that Mark's solution, Mark's idea of the web, is not compatible with the one she is hoping to build. Ultimately, though, we can only hypothesize about the motivation behind these changes in narrative tense, as we have to do so frequently in this rather unusual text. It is part of Krauß's poetic style that when we get to the end of Weggeküsst, there are still uncertainties and spaces to be filled. A particularly effective and powerful sleight of hand is how Krauß ends her narrative in mid-dialogue. Leaving this obviously important conversation unresolved reinforces the narrative's open-endedness and adds a touch of mystery to the work's final scene. The last word is with the reader. 
I shall conclude my discussion of Krauß's narrative method with a few remarks about narrative pace and rhythm in Weggeküsst. The work's narrative rhythm is characterized by a unique and constant tension between mobility and stasis. On the one hand, there is the often intense movement of the narrator's thoughts, a representation of an overly active mind; on the other hand, there is the conspicuous absence of external action, especially in the first six chapters of the narrative, which is the instantiation of the woman's inner paralysis. The various digressions into reflection, recollection, and reported dialogue interrupt and thus slow down the progression of external action. But as far as internal action - the narrative of words - is concerned, these shifts between different discourses reflect restlessness and tell of a mind constantly probing and searching. The many temporal ellipses are also noteworthy. They leave the reader with the awareness of time unaccounted for and push the narrative forward in spurts rather than in a continuous flow - yet another formal realization of the narrator's psychological state. This constant change between different narrative strategies and discourses combined with the uneven pace of the narrative give Weggekiusst a unique kind of rhythm. With its irregularities, its ellipses, its gaps, and its leaps it is the poetic representation of a mind in search of stability and order.

\section{The Web, the Wall, the Letter}

One element that greatly contributes to the aesthetic refinement and the poetry of Weggeküsst is Krauß's awareness of the power of language. This aspect of her art is reflected most forcefully in her skillful interweaving and repeating of various images and motifs so that their meanings keep changing and developing as the narrative progresses. 
This technique is part of Krauß's method of writing and her intention to move beyond the appearance of things. Perhaps the most noteworthy trademark of her style is her ability to discover the exceptional and the magical even in the most mundane, commonplace situations. At the same time, however, she also knows that she is working with a medium that has been contaminated by everyday use. How, so she asks, can a writer evoke new experiences and touch her readers' hearts, if her instrument - the Sprachapparat-has long been dulled and corrupted by everyday use and abuse. In a conversation with poet Thomas Rosenlöcher, she remarks, "Wir müssen ja das mitbenutzen, was den Leuten schon Tag für Tag zum Munde heraushängt. Wir versuchen trotzdem, mit dieser Sprache jemanden ins Herz zu treffen" (27). To touch someone's heart, to have the arrows of her language penetrate to the deepest layers of the reader's being, this is Krauß's goal, not just in Weggeküsst, but in all of her fictions.

A thorough study of the intricacies and different facets of Krauß's imaginative play with language in Weggeküsst would go beyond the scope of this project; therefore, I shall restrict myself to a brief discussion of one of the more important poetic aspects in Weggeküsst - the repetition and gradual development of three of the work's central motifs and images - the web, the wall, and the letter.

The most frequently mentioned image, and the one that is most important for the narrative, is das Netz, the web. ${ }^{108} \mathrm{Krau} ß$ introduces the idea of the web in the context of

${ }^{108}$ I decided to use "web" as the English equivalent to Krauß's Netz. Other options would have been "net" and "network." The latter I find simply too unpoetic although the word also has a non-technical meaning. The former would certainly be an acceptable translation, but the word "web" is the most poetic of the three options. Since "web" refers to something organic and alive, I think it best conforms to Krauß's poetic use of language. Also, "web" describes how the way the narrator used to connect with the world, as described at the very beginning of the narrative, and it relates to the idea of the 
one of the narrator's contemplative digressions halfway through the first chapter. Because she cannot help but be curious about the world, the woman tells us, every morning she falls victim to the abundance of impressions that greet her as soon as she steps out of her door. She is almost obsessed with this need to weave into her web everyone who crosses her path. Here, in this web of her desires ("das Netz meines Verlangens"), she stashes away everything she ever longed for and loved, everything that she ever included or rejected (13). This is her nature; this is who she is.

The web stands for the narrator's belief in the interconnectedness of life. It represents the idea that other people's lives together with our own experiences are in some way woven into our lives and into our future. This notion is, of course, a major theme in the German Bildungsroman and calls to mind such works as Goethe's Wilhelm Meister, Novalis' Heinrich von Ofterdingen, or even Büchner's Lenz. But as I am about to explain, in Weggeküsst the allusion has a deeply ironic undertone. Aside from conveying the idea of a connectedness between people, the web also represents the narrator-protagonist's curiosity (Neugier) about people and life in general and stands for her longing (Verlangen) for unbounded experience (das Grenzenlose). She tells us that she developed and nurtured these qualities during a period in her life when she was shut out from the other, the non-socialist part of the world and when the scarcity in her own life inspired her imagination. At that time, building her web defined her existence and gave her life a sense of purpose. "Unendlich viele Leben warteten immer auf mich, "she tells us (34). In her imagination she would prepare herself for the moment when she

narrator's need to collect all she ever experienced, to hold on to it, and to weave her experiences into the web of her life. Finally, web alludes to the myth of the three Moirae, which adds a mythical dimension to the image, and this is certainly part of Krauß's meaning. 
could venture into the rest of the world, while longing for the day when these other lives would finally be accessible to her.

When she now talks about her Netz, however, she does so with a touch of nostalgia and a sense of loss. During the time before the historical turn and only for a short period immediately thereafter-the time when the newness was still exciting and invigorating - her curiosity was at its peak, she tells us, and her imagination was the most active. But as the years went by, disillusionment set in. Now, almost a decade later, the world with its material wealth and its flood of impressions makes her feel strangely disconnected from what she once desired, and she no longer knows where to turn. Ironically then, and contrary to what she had expected, venturing out into the world the way her literary predecessors did no longer works in this new world, where a person is constantly barraged by an overload of impressions. Not new knowledge and new insights, but a lack of understanding (Verständnislosigkeit) has now become her state of being while her former needs have atrophied.

The narrator describes her despair during a chance encounter with the Konditormeisterin. Hoping that this woman with whom she feels a sense of kinship will have some meaningful advice, the narrator tells her (in almost identical language to her monologue in the first chapter, by the way) about her web-what it once meant for her, and how, ever since life started to change twelve years ago, it has begun to dissolve. She no longer knows where she belongs and everything that she once collected in her web is now in danger of being forgotten. "Es [ das Netz] wuchs nach außen, es wollte die ganze Welt erobern," she explains. "Es hat sich aufgelöst!" (70). And as a final cry for help, she 
adds, "Ich löse mich auf! (71). The Konditormeisterin's cold response: feeling good about life is nothing but a bio-chemical reaction.

But even if this world threatens to fall apart, there are other worlds, that of nature and of the imagination, that offer consolation. With this in mind, the narrator's thoughts turn to yet another Netz, to a flock of screaming black crows that in a wave-like movement descends upon the city. Whether this image of the black birds is real or whether it only happens in her imagination, we don't know and it does not matter. It is how this scene affects the narrator's consciousness that establishes its meaning. The sight (or perhaps vision) of this web of black, screaming birds gives the woman a sense of inner peace and comfort. The round, warm bodies flying in total unison remind her how everything in nature is pervaded by a sense of purpose and deep-seated serenity. Not among people but in nature, so she already knows from her occasional excursions to the zoo, will she be reminded of what is most important in life.

There is yet another kind of Netz that is gradually taking over the world - the communication network. Its advocate is the narrator's American acquaintance, Mark. She met Mark shortly after the historical turn, and she felt drawn to him because of his unbounded enthusiastic about life. He knew what he wanted and passionately believed in his goals. Also, always having been intrigued by this "unaussprechliche Wort," communication, she was captivated by Mark's praises of the communication network (das Netz) and by the idea of networking (Vernetzung). Being connected with the world, so Mark announced, meant the end of ideology and confusion. From now on, he promised, man's existence would be "fließend, chaotisch, lebendig und frei [ ] und nicht 
mehr an Orte gebunden" (42). At that time, Mark's world seemed to the narrator like a secret society, one that, so she hoped, would help her find direction in her own life. ${ }^{109}$ When in the next to the last chapter and by implication years later, Mark (now vice-president of an information service business) crosses the narrator's path again, she finds herself once more captivated by Mark's ideas. Meanwhile, however, his sales pitch has changed. Instead of emphasizing the liberating qualities of the web and networking (freedom and liberation were of course driving themes in the post-Wende East), Mark now praises the web as a fast and easy method of making money. Becoming part of the network, he promises, means life-long wealth and the freedom to enjoy a life free of responsibilities. (The difference in Mark's argumentation during their second meeting, by the way, reflects quite poignantly how under the progressive Westernization of the East, people's expectations had undergone a significant change. Freedom and liberation, key ideas right after the Fall of the Wall, have lost their persuasive power a decade later. Making money — fast and easy money — is now the dream of everyone in the East just as much as in the West.)

It is not the promise of wealth or a carefree life, however, but Mark's remark about the Grenzenlose-a word frequently mentioned in the narrator's monologue - that gets the woman's attention. "Seien Sie Meister im Grenzenlosen," Mark calls out to his audience, and promptly the narrator is taken back to her childhood. She sees herself, her

${ }^{109}$ That Krauß made Mark, with his unwavering optimism, his belief in the power of the communication network, and his passion for easy money an American is part of her tongue-in-cheek play with East German stereotyping that we already encountered in Die Überfliegerin. And having done her homework, Krauß has Mark, the man who comes from "dem Land der grenzenlosen Möglichkeiten" (the land of unlimited possibilities, as Germans like to call the USA), lecture to his audience about being masters of the Grenzenlose. 
friend Tine, and Tine's brother playing on the wall surrounding their yard. This is a crucial event in the narrator's past, as we learned in the previous chapter, and the image of the children running along the wall brings back memories of childhood innocence, carefree play, and an unwavering conviction of her own uniqueness. The narrator never directly comments on Mark's ideas but is obviously intrigued by them as implied in the particular memory Mark’s words evoked.

But will Mark's Netz really be the solution to the narrator's problems? To be part of his network, so Mark promises, all a person has to do is count people; the larger the number of people who participate, the larger the profit. Who or what these people are is meaningless and unimportant.

Counting, zählen, is a concept we already encountered earlier in the narrative, when the narrator tells us about Hubertus, the mailman. Zählen was Hubertus' method of trying to re-gain a sense of order when life in the post-Wende East was turned upside down. Hubertus's dealing with the world consisted of counting and categorizing everything he encountered according to its appearance. "Das Zählen der Erscheinungen," so he once explained to the narrator, "schließt Wertung und Urteil aus, es läßt sie sein, was sie sind" (53). In other words, by counting Hubertus avoids thinking about the world and its meaning. But for the narrator, participating in life means probing beyond surface appearances, so the mailman's method is in fact contrary to her own approach to the world. Hubertus, she says, is only interested in an abstract representation of the world, in a world that is reduced to a succession of numbers - "ihr Abbild als endlose und 
ausdrucklose Zahl" (54). ${ }^{110}$ She, on the other hand, wants to transform the world and make it part of her own life. Mark's approach to people is like that of Hubertus and adopting it would require a fundamental change in her attitude towards life and towards people. People would only be become a means to an end. "Ich müßte meine Freunde zu Nummern machen, anstattt an ihren seltsamen Leben teilzunehmen," the narrator quietly replies to Mark's suggestions (96).

Building a web, a network of the kind that Mark is talking about is not an option for the narrator, but still, the chapter ends with the positive image of the narrator running with her friends along the top of the wall. Her final thought, "ich ahnte es: wenn wir nur wollen, sind wir wieder oben," expresses a kind of excitement and energy that so far has been conspicuously absent from her monologues (97). Mark may not have been able to provide the narrator with the solution to her problem, but his positive thinking and his enthusiasm about life, so we may infer from the chapter's final image, rekindle in her the desire to give people and her new life another chance. ${ }^{111}$

Another central image in Weggeküsst, one whose full meaning is not revealed until later in the narrative, is that of the wall. (I am using the wall as a kind of shorthand

${ }^{110}$ In his essay, "Angela Krauß: Diskrete Botschaften oder das Erzählen, das aus der Zahl kommt," published in Die Ethik der Literatur: Deutsche Autoren der Gegenwart, critic Stephan Krass draws a connection between the mailman's (Hubertus's) philosophy about life and Krauß's narrative method in Weggekïsst, at the center of which is the idea of collecting. Krass writes, "So entstehen immer wieder Augenblicke, in denen sich Phänomene, Begebenheiten, Dinge zu einer Liste, zu einer Aufzählung, zu einer Erzählung fügen, bei der die einzelnen Faktoren keine Summe ergeben müssen. Das Erzählen, das aus dem Zählen kommt, orientiert sich nicht an einer Weltformel, in der die einzelnen Teile ein Ganzes ergeben müssen. Das schafft Freiheit" (116).

${ }^{111}$ The chapter has almost a fairy tale ending very much like that of The Sleeping Beauty. We can envision the narrator as the sleeping princess, whose fear of life gets kissed away (weggeküsst) by the young prince Mark. With his enthusiasm about life, Mark manages to free the narrator from her paralysis, her fear of taking action, and awakens in her a new interest in life. 
for the narrator's most meaningful childhood memory - that of playing with Tine and her brother on top of the wall that enclosed their yard.) The wall and the experiences related to it are arguably the most powerful and emotionally charged image in the whole narrative.

Tine (and by implication the wall) is first mentioned at the end of the first zoo chapter. As the narrator thinks of how the animals so uninhibitedly announce their presence to humankind - with voices "sehnsüchtig [ ], hemmungslos, stark" - she is reminded of her childhood friend Tine (25). She and Tine were inseparable, and together with Tine's brother, they were the unrivaled masters of their neighborhood, the narrator tells us (25). Although the deeper implications of this memory are not revealed until later in the narrative, the context in which the scene is mentioned already establishes its unique importance. Just as the zoo represents a special place for the narrator-a place where she can escape from life's pressures and complexities - the memory of her friendship with Tine seems to offer her a similar kind of mental escape.

Two chapters later, the narrator confesses that she thinks of Tine only when she no longer knows what to do next and is confronted with her fear of taking action. The image she conjures up in such moments of crisis and self-doubt is that of the girl dancing on the wall like a high-wire artist (50). Tine, with her determination and fearless daring, is the Lebenskünstler that the narrator wishes to be.

It is not until chapter six, however, that Krauß has her narrator reveal the full meaning of her and her friends' play on top of the wall. This memory, we now find out, belongs to a time in the narrator's life when she was still convinced of her own importance and uniqueness. For one summer, the narrator's and her friends' lives 
revolved solely around their noisy play on the wall. It was a place to which no other child was admitted and that set the three apart from the rest of the children. "Alles was unser Leben war: .. . wurde einmalig, unverwechselbar und merkwürdig durch sie [the wall]," the narrator remembers $(80)$.

Central to this memory is the sound of the children's feet on the hot metal that covered the top of the wall - the hitting, clapping, tapping, and drumming that would get increasingly faster, louder, and wilder and that would echo throughout the neighborhood. This sound would loudly announce her presence to everyone around and assure her of her own uniqueness and importance. "Denn nur wir konnten unsichtbar und unverwechselbar verkünden, daß es uns gab: denn unser war die Mauer,' the narrator concludes (81). Having conquered the wall by being able to jump up and run along its top like Tine and her brother, the narrator at that time had a sense of total freedom and invincibility.

When at the end of chapter seven, the audience's enthusiastic applause of Mark's speech reminds the narrator of the clapping sound of her feet hitting the top of the wallthe "trampeln, klatschen, schlagen, hacken und trommeln"- - we are invited to think that at this moment, the narrator feels her former strength of will and her sense of self return. She can indeed change her life, if only she puts her mind to it as she did years ago on this wall. $^{112}$

${ }^{112}$ Is it possible for an East German writer to talk about a wall and not think of the Wall? Whether or not Krauß is drawing on her personal memory or not the wall from Krauß's childhood represents exactly those ideas - freedom and a sense of independence - that the Wall between the two Germanys took away from its citizens. Is Krauß here deliberately ironic, or is the narrator perhaps simply implying what she mentioned earlier - how in her old life, during the years of the Wall, her imagination was freer because then it was limitless. 
I shall conclude my discussion of some of the narrative's major images by talking about an object that is rather inconspicuous at first, but that in the course of the narrative takes on great symbolic significance - the letter. Krauß gradually establishes and expands the meaning of the letter-and with it the phrase keine Angst-in much the same way as she developed the two other images, the web and wall. We learn about the letter in the first chapter of Weggeküsst, when during her conversation with the man sitting across from her, the narrator suddenly takes an envelope out of her pocket and passes it to him. In this envelope, so she gradually reveals, she keeps a napkin with a message and a drawing that was given to her by a stranger who once sat next to her on a flight across Florida. Though we never learn the exact wording of the message, we soon find out that it was meant to calm her fear after the plane had briefly lost altitude.

In fact, not only is the content of the envelope a mystery, but the story about where and why she received the letter is quite unusual also. How long, we wonder, has the narrator been carrying this letter in her pocket? Why is she showing it to this stranger, and why does she keep telling the man that he need not be afraid-afraid of what? When she advises him, "Hier steht alles drin," she makes it seem as if he needed reassurance, but neither he nor the reader knows what exactly this "alles" may be (18). The more she talks about the letter, the more we get the impression that it is she, and not the man across from her, who needs help and reassurance. It almost seems as if she were attributing to the letter some kind of magic power to protect her from harm and take away her fear. But why fear?

As the narrative progresses, the phrase keine Angst is transformed into a leitmotif. It is directly related to the narrator's paralysis, to her fear of making decisions and taking 
action. Every time she becomes aware of her current unhappiness and realizes that she needs to stop drifting through life, she thinks of the phrase keine Angst, as if to reassure herself that there is indeed nothing to be afraid of because everything in life is relative.

It is not until the second to last chapter, during the narrator's second encounter with the silent stranger, that the mystery of the letter is finally solved. The man on the plane, we now find out, was a pilot, and by drawing on the napkin the pattern of the sky's gulf stream, i.e., by providing an informed, scientific explanation for the sudden plummet of the plane, he made the narrator realize that there actually was a natural explanation for what she had perceived as chaos. But it was less the explanation that was so memorable to the narrator than the situation itself - that her neighbor was able to provide emotional comfort (hold her hand) while at the same time being rational (drawing the diagram). It is this ability to act emotionally and rationally at the same time that defines the essence of being human and that sets us apart from the animals, the narrator suddenly realizes. Mankind "kennt Aufzeichnung," and our ability to reason gives us control (92). Unlike the animals, which act according to instinct only, we can understand the causes (and implicitly detect order) behind what at first might seem a sign of chaos. The man's note, so we now come to understand, is a constant reminder for the narrator that not everything in life is out of her control.

Knowing the true implication of the letter also changes our interpretation of the narrator's behavior earlier in the coffee bar. Passing the letter to the stranger, we now realize, is more than just the woman's feeble attempt at making contact. Instead it could be seen as her first step towards taking control of her fear. Moreover, the fact that she offers the stranger what is for her an important object shows a sense of trust and signifies 
her interest in this person. ${ }^{113}$ Most importantly, though, knowing about the meaning of the letter helps us understand the ending of the narrative, that enigmatic moment when during their conversation by the lions' corral, the narrator throws the letter into the enclosure. This gesture, aside from being a very poetic and theatrical finale, represents an act of liberation and courage. Having regained confidence in the power of her will and having found someone whom she can trust, the narrator is once again ready to face whatever challenges life has to offer and take charge again of her life.

This change in the narrator's attitude is also reflected in her behavior during these final few moments by the lions' enclosure. It is obvious that she is now the one in charge whereas her partner seems puzzled and confused. This final scene mirrors the scene on the airplane with the one decisive difference that the woman has now taken on the role of her pilot neighbor: it is she who now gives a rational explanation for the lions' behavior, and it is she who now calms her partner and tells him, "Keine Angst!" Her last words are "Sie [the lions] jagen nachts" (105). The calm composure with which she announces this fact shows us that she is ready to face the life's challenges.

Whether it is the Netz, the wall, or the letter, each of these motifs exemplifies the sophistication and imagination of Krauß's style-how she gradually develops each image and carefully interlaces it with other, related images and motifs in order to deepen its meaning. This method gives her work a dynamic quality. It counterbalances the narrator-

${ }^{113}$ In fact, this scene marks the beginning of the narrative's love-plot. As we find out later, the stranger actually took the letter with him, which is Krauß' way of establishing a sense of connectedness between the two people. At the end of the novel, we learn that the stranger has actually kept and carefully guarded this letter, which makes it seem as if there had been some kind of silent understanding between him and the woman. He intuited the letter's importance and perhaps also sensed that he might at some point have a chance to return it to her. 
protagonist's lethargy, and most importantly, it gives the final two chapters their positive tone. Last not least, the repetition and intertwining of the work's central images and motifs provide a sense of coherence to an otherwise fragmented text. In this sense, the structure of Weggeküsst very much resembles that of a web. Meaning arises less from what is being said at one particular moment than it gradually emerges from the way these moments are interwoven and complement each other.

I want to return briefly to the narrative's concluding lines in which Krauß showcases her poetic sensitivity and her mastery of language one last time. With a language reduced to its absolute minimum, Krauß evokes a maximum of meaning. ${ }^{114}$

Was tun sie?

Keine Angst!

Sie haben ihn [the letter] in die Löwenanlage geworfen!

Hören Sie: wie er aufschlägt!

Es hat gefaucht. Sie schlafen doch aber längst?

Nein, nachts sind sie hellwach, das ganze Rudel.

Das sagen Sie jetzt erst.

Sie jagen nachts. (105)

With a few short but powerful strokes Krauß here captures the moment without assigning it any meaning. The intensity of the scene has a surreal quality, which is further emphasized by the open ending. It is exactly the distinctly physical quality of her images coupled with a simple, almost matter-of-fact, and highly concrete language that gives this final scene its poetic power.

${ }^{114}$ Line changes in the quote indicate a shift in speaker. The passage starts with the narrator's companion speaking and ends with the narrator's words. 
Some critics consider the open ending a serious flaw in the narrative's composition. In his review of Weggeküsst in the Frankfurter Rundschau, the critic Navid Kermani, after having praised Krauß's concise and highly poetic language, chides her for the work's open ending and tersely concludes that the novel leads to nothing. Ultimately, the protagonist is going nowhere, he writes. For reasons explained above, I strongly disagree. In fact, I cannot think of a better way for Krauß to realize her poetics of pure and uncontaminated presentation than by having the situation speak for itself. Any kind of more explicit and conclusive ending would have been a violation of what Krauß deems the most important aspect of her writing. It would have destroyed the scene's inner tension and would have spoiled the reader's pleasure (to speak with Roland Barthes) in constructing its meaning.

Krauß once remarked in a conversation with the poet Thomas Rosenlöcher that one must not make literature into non-art ("eine Unkunstrichtung"). A certain kind of inner tension, she calls it "ein Begehren, ein Spannungsverhältnis," is essential to art. Literature, she says, "hat mit Momenten unter einem Schneestrauch zu tun" ("Stockende Tinte,” 27). In Krauß's Die Überfliegerin, the narrator experiences several such significant moments; Weggeküsst ends in one.246

\section{Conclusion}

I shall now turn to the topic of Krauß's Weiterschreiben in Die Überfliegerin and Weggeküsst. The GDR-ness of the two narratives is quite obvious. Both texts were inspired by Krauß's own experience with life in post-Wende East Germany. Though one must not confuse fiction with biography, we know from Krauß's own remarks that for 
her, there is a direct connection between literature and life. Both narratives deal with one of the fundamental issues East Germans were confronted with during the country's Westernization: how to rebuild their lives, overcome their sense of loss, and recapture their sense of identity. In the history of Krauß's own Weiterschreiben, Die Überfliegerin, her first post-Wende text, stands out because it marks a turning point in her writing. Krauß had experimented with first-person narration, but her preferred method had been third-person narration. Her two longer narratives, Das Vergnügen and Der Dienst, both a great success with West German literary critics, were written in this mode. And even in her first-person narratives, Krauß generally used retrospective instead of simultaneous narration. In fact, only two of her short narratives, "Das Glashaus" and "Kleine Landschaft" (both from her collection of stories entitled Das Glashaus, published in 1988), were written in first-person present-tense narration, and they share the same poetically charged language of the Leipzig chapter of Die Überfliegerin. Though Die $\ddot{U}$ berfliegerin is consistently written from a first-person perspective, we can still see traces of Krauß's experimentation with the different options of first-person narration. At the same time, there is no doubt that the literary quality of the Leipzig chapter-the complexity of the narrating and its poetic language-supersedes that of the narrative's remaining two chapters that are written as retrospective narration. Krauß's next text, Sommer auf dem Eis, was written exclusively as first-person monologue and like Die $\ddot{U}$ berfliegerin is a text of self-exploration. From now on, this became the mode of narration of all of Krauß's narratives. In fact, one could even argue that the two modes of narration we find in Die Überfliegerin represent Krauß's own search for a voice with which to respond to the social and political changes around her. I mentioned earlier that 
the unusual beginning of Weggeküsst echoes one of Krauß's early stories, "Ströme.” In their differences and similarities, these beginnings mirror the dramatic changes that swept through East Germany in the intervening years.

As for the GDR-ness of Krauß's writing style, the most noticeable connection is with Christa Wolf. The way Krauß interweaves personal experience-the subjective and authentic - with invention and poetic imagination immediately brings to mind Wolf's method of subjective authenticity. Like her compatriot Christa Wolf, Krauß draws heavily on her own life and personal experience, and her fictions are characterized by a unique merging of fictional and autobiographical elements. But unlike Wolf's works, Krauß's narratives are free from political undertones; her concern is first of all the individual human being and her perception of herself and of the world around her. Social, political, and ideological issues are important only as they affect an individual's personality and life. Her subject matter, as she explains in her essay, "Mit der Zeit erzählen," is “gelebte Lebensgeschichte"-a lived history of life (122). But as in Hensel's Gipshut, in Krauß's narratives, too, one can detect connections with Morgner's narrating, though to a lesser extent than in Hensel's novel. In Die Überfliegerin as well as in Weggeküsst, there are numerous instances where the writing takes on a dream-like and fantastic quality. I mentioned the surrealism of some of the travel scenes in Die $\ddot{U}$ berfliegerin and especially the surreal and nightmarish quality of the Moscow chapter. In Weggeküsst the shift to the fantastic is not as clear-cut, but in the narrator's overly active mind, the real often takes on a poetic, dream-like quality, as for example in the narrative's final scene. I discussed the different aspects of Krauß's ironic method in Die Überfliegerin, where irony is more prevalent than in Weggeküsst. In both of the travel 
chapters, Krauß plays with some of the preconceived notions the typical East German entertains towards the two Cold War enemies, the United States and Russia. The title of the later work, Weggeküsst, with its allusion to the fairytale "Sleeping Beauty," is a playfully critical reference the post-Wende relationship between East and West Germany. In Krauß's narrative, the sleeping beauty (the East) is kissed awake by her prince (the West) to a world whose promise of eternal happiness is nothing but a sham. Most of the text's irony, however, lies in the narrator's self-deprecating pose and in the way she always maintains a sense of detachment even in the midst of her despair.

The previous discussion of Krauß and her connection to the GDR's literary tradition shows that Krauß very much developed her own way of transforming experience, life, into literature, though in her works there are certain echoes of other GDR writers. I shall conclude this chapter with a few additional remarks about the exceptional nature of her writing. Critics generally have a difficult time labeling Krauß's works. Her texts are too short to be called novels, but they also do not quite fit into the short-story genre because they are almost devoid of plot. Krauß is not a storyteller, unlike Hensel. Even in Die Überfliegerin, the text that offers the most plot-like passages, the narrator-protagonist's reflections outweigh straightforward narration. One way to describe the form of her narratives is to compare her texts to a web or a kaleidoscope of observations, snapshots, impressions, and fragments of memory. Indeed, critics generally resort to metaphorical descriptions rather than literary terminology when talking about her style of writing. Norbert Otto Eke, for example, gives his discussion of the evasiveness and open-endedness of Krauß's narratives the poetic title, ’Das Schweben und die Form.” In her review of Wie Weiter, Carola Wiemers compares reading the 
narrative to a "sprachliches Tanzvergnügen" (a blissful dance in language), an analogy that certainly is true for Krauß's other texts as well. And in his Laudatio to Angela Krauß on the occasion of her receiving the Hermann Lenz-Preis, Peter Hamm uses expressions such as "Lichthunger" (hunger for light), "Zartheiten” (tendernesses), and "sehnsüchtige Sinnlichkeit" (longing sensuousness) to describe Krauß's aesthetics. Poetic language is of course an essential ingredient to all good literature, though some writers are more poets than they are storytellers, and this is certainly the case with Angela Krauß. This takes me back to the topic of Weiterschreiben. I mentioned Christa Wolf as the writer from the former GDR whose works remind me the most of Krauß's narratives, and this is especially true for Wolf's post-Wende narratives. The dense, poetic language of the narrators' monologues and the loose structure of her highly controversial Was bleibt (1990) and of Leibhaftig (written in 2002, more than a decade later) remind me, despite the many differences between these two writers, of the intensely poetic monologues of Krauß's narrators.

I shall conclude this chapter on Angela Krauß and the Weiterschreiben of GDRliterature with a quote from one of my favorite works by Christa Wolf, Kassandra. Wolf writes, "Es ist das andere, . . . das Dritte, . . das lächelnde Lebendige, das imstande ist, sich immer wieder aus sich selbst hervorzubringen, das Ungetrennte, Geist im Leben, Leben im Geist," (124/25). I consider this connectedness between spirit and life, life and spirit, to be the defining characteristic of all of Angela Krauß's post-Wende narratives. It gives them their utopian tone and shows that Krauß and Wolf, despite their differences, are indeed kindred spirits. 


\section{Conclusion. The Weiterschreiben of GDR-literature}

\section{Hensel, Krauß and Weiterschreiben: A Summary}

Before returning to the topic of the Weiterschreiben of GDR-literature and the question of a post-GDR GDR-literature, I would like to give a brief summary of the ways in which the three fictional narratives by Hensel and Krauß represent a Weiterschreiben, a continuation, of GDR-literature.

First of all, both writers continue to write after the Wende, and in both cases, living through the period of change and adjustment inspired their creativity. As for their writing styles, one can see continuity as well as evolution. Ironic wit, a penchant for the bizarre, and a special fondness for creating characters with grotesquely misshapen personalities has always been Kerstin Hensel's trademark. She always defied tradition and kept challenging her readers with her critical view of human nature and her defiant humor. One of the changes in her writing that was inspired by the new situation in the East is that during the mid-1990s she further developed her talent as storyteller and started writing longer fictional narratives, parodies of Epochenromane, that span several decades of the country's history. Angela Krauß's trademark has always been the poetic language with which she transforms even the most mundane, everyday scenes into reflections of her characters' emotional state. The calm gentleness and warmth of her prose speak of her love of people and of life. As with Hensel, her narrating is highly idiosyncratic, at times even enigmatic, and not beholden to current literary trends or the demands of the market. Because she is a poet at heart, action and plot have always been of secondary importance for Krauß, and even her earliest stories read more like a carefully composed collection of images and impressions than traditional narratives. Like 
Hensel, Krauß had just started her career as a writer and was still relatively unknown when the Wall came down, and in her case too, witnessing East Germany's transformation after the Wende led her writing in a new direction. She shifted exclusively to first-person narratives, interior monologue became her preferred mode of representation, and more and more she moved towards an open, associative way of narrating almost devoid of plot.

Second, the three fictional narratives discussed in chapters two and three also represent a Weiterschreiben in the sense that they have a distinct regional quality with respect to setting, subject matter, and themes. The everyday reality they describe, including the various conflicts and the themes that shape these narratives, are particular to the social, cultural, and political environment of the GDR and the post-Wende East. At the same time, each author writes about distinctly different aspects of East Germany's past and present and focuses on different issues, thus providing perspectives that in their dissimilarity are also complementary. These works are not only paradigms of a Weiterschreiben of GDR-literature, and they also attest to the complexity and diversity of this phenomenon of GDR-literature after 1989. Of the three texts, Gipshut is most deserving of the label regional literature. It reads like a fictional chronicle of almost fifty years of East German history - forty years of the country as a socialist state and the first nine years after the Wende. This double perspective is directly reflected in the novel's two plot lines. Despite the fact that Gipshut was never intended to be a piece of realistic fiction and includes many fantastic elements (not to mention its surreal ending), the novel still has a feel of authenticity. The setting is modeled after real places, and Hensel keeps weaving little pieces of realistic detail into the otherwise so deliberately distorted 
portrayal of life in the former GDR and the new East. ${ }^{115}$ Krauß's Die Überfliegerin and Weggeküsst, too, are typical GDR/new East narratives, but her concern is primarily with the life-changing effects of the historical turn. In these narratives Krauß gives artistic form to the existential fears that defined life immediately after unification — the East Germans' sense of disorientation, their uncertainty about the future, and their sense of loss. But while struggling to catch up with the changes around them and not be left behind by life, Krauß's characters never despair and never lose their love for life and their curiosity about people. The issues that her narrators find themselves confronted with are unique to the history of Germany's new East. Only in the East did people experience this acute sense of rupture and sudden disconnectedness. Only they felt, as Jana Hensel puts it so poignantly in her childhood memories, After the Wall, that "[their] past has been locked away in a museum with no name and no address," while in the West life kept moving along its old familiar ways (12). Though set in the post-unification present, Krauß's stories are also about the GDR past, as memories of their GDR childhood gives her narrators a sense of belonging. In both narratives, recalling her spirited and resilient grandmother and letting her thoughts return to the rugged and mythical landscape of the Erzgebirge are the narrator's sources of strength and inspiration. Though most of Die Überfliegerin is set in places other than the GDR — the United States and Moscow — this inconsistency is consistent. This examining of what this world that was previously locked away from them has to offer is an important part of the post-Wende East German experience. That the narrator's thoughts turn to the United States and Russia, of all

${ }^{115}$ Her story of the Berliner Stadtschloss is an excellent example of how she mixes fact with fiction. She uses a true historical event in order to then write her own history. 
places, is defined, by the unique history of her country, a country whose existence was the product of the East-West tensions during the Cold War.

Concerning the similarities and differences between the two writers and their works, one important connection is their historical awareness, a deep understanding for how people's lives are shaped by history's turbulences. This is also something they share with writers from the GDR and their colleagues in the new East. Though Hensel and Krauß both use as their Material the social, political, and historical realities of life in the GDR and the new East, each focuses on different issues and themes and uses distinctly different ways of representation. One such example is the kind of function they assign to the past and the importance of remembering. In Gipshut, the past means the GDR's history, and specifically the decades when the country was under the oppressive regime of an authoritarian socialist government. Hensel is interested in how historical processes shape people and affect their relationship to others. For Krauß, the past means first of all personal history and memories of the people and the physical environment that contributed to the shaping her narrator's personality. Unlike Hensel, who prefers an impersonal mode of narration, Krauß integrates aspects of her personal history into her texts, which often results in a merging of the two voices, narrator and author. Moreover, though Hensel and Krauß both write about the past in order to prevent forgetting, they do so for different reasons. For Krauß, the past is an integral part of our identity. Not only does knowing about our past help us better understand who we are now, but our memories can also give us a sense of stability and belonging in times of crisis. Remembering as part of finding direction in life is an important theme in all of Krauß's narratives. Krauß's relationship with the past is characterized by nostalgia. Hensel, on the 
other hand, has a critical attitude towards the past; hers is an impersonal, a historically defined, and a highly critical kind of remembering. In response to the sudden disappearance of the state GDR, she wants to keep alive the memory of history's mistakes and of the many wrongs people were subjected to in the past. She writes about the past with the careful and critical look of a detached observer. ${ }^{116}$ Not surprisingly, Hensel and Krauß also view the post-Wende present from different angles. The many fantastic and fairytale-like elements in the Anna/Paul story of Gipshut, the falling out of time in the novel's final pages, and the surreal ending transform the description of East Gemany's post-Wende present into a humorous satire. They are Hensel's way of criticizing the rapid Westernization of the country, people's unrealistic expectations, and their false hopes of a better life. Krauß, in contrast, chooses to approach the subject from a more personal perspective and focuses on psychological and emotional responses to the change. Though confused and disoriented by the sudden rupture in their lives, her narrators also embrace the newness. They may not know how to deal with their newly found freedom, but they are also attracted to it and want venture out into it. But Krauß, too, is not uncritical of the changes as reflected in the subtly ironic tone of her narratives. The sudden abundance invites superficiality so that - and this is an important theme in Weggeküsst-it is easy to lose oneself.

${ }^{116}$ In her essay "Über dem Jammertal. Vergangenheit - geschichtlich und gegenwärtig," Hensel writes that when looking at the world as a whole, it is the task of a writer not just to touch the sensitive spots of world history, but to keep the wounds open "die Schmerzpunkte nicht nur berühren, sondern die Wunden offenhalten." Most importantly, though, it is the writer's responsibility to overcome nostalgia and forgetting because forgetting puts society in danger of repeating previous mistakes - "wer vergißt, muß wiederholen" (35). 
If for each of these writers one were to choose one representative from the former GDR whose writing style and approach to literature most closely resembles theirs, it would be Irmtraud Morgner and Christa Wolf. Though Morgner's influence is not as noticeable in Gipshut as it is in Hensel's previous work, Auditorium Panoptikum, the novel still shows the influence of Morgner's aesthetics. One obvious connection between Gipshut and Morgner's post-modern style of writing is Hensel's use of magical realism and her penchant for exaggeration, which often gives her writing its typical humorously grotesque Morgnerian tone. Another resemblance is Hensel's choice of narrator: the ironically detached tone and deadpan humor is reminiscent of the narrator in Trobadora Beatriz, not to mention Hensel's wit and play with literary traditions, which are both characteristic of Morgner's writing. Though Hensel's satire can at times be biting, like Morgner, she softens the blow with a thorough dose of comedy. Another strategy favored by Morgner that Hensel also uses extensively in Gipshut is the self-conscious exposing of the text's fictionality. Like her compatriot Morgner, Hensel keeps deconstructing the fictional reality she herself constructed, thus never letting the reader forget that she is reading a piece of fiction. Such distancing of the reader is not Morgner's invention but goes back to such political writers as Bertolt Brecht, Volker Braun, and Heiner Müller. Though Hensel is not interest in politics per se-i.e., party politics - she has a keen eye for such problems as social injustice, dogmatism, and conformism, and her writing is certainly political in the sense that with it, she wants to alert people to these evils. In general, Hensel's original way of manipulating the novel's narrative structure and her creative play with voice and mood have been an important aspect of the GDR's literary tradition ever since Nachdenken über Christa T. 
I previously called Gipshut a local color narrative, and indeed all of Hensel's fictions share this characteristic. Writing about simple, working class people or about common folk from the provinces is a GDR tradition that goes back to such writers as Johannes Bobrowski, Erwin Strittmatter, and Günter de Bryn. In particular in the Hans and Veronika story, Hensel displays her talent for depicting the essence of small town life in the former GDR with a few well-placed strokes. The precise and acute detail of her descriptions deliver a sense of authenticity, though just as with these writers, it is not realism in the sense of presenting a truthful copy of reality that she is striving for. She wants to evoke an abstract kind of truth, one that is true to the experience, and to deliver this truth one has to penetrate beyond the surface appearance. Interweaving her protagonists' personal stories with various aspects of GDR history allows her to expose the tragic aberrations of recent historical phenomena while at the same time reminding her reader of people's fallibility in the face of political and historical developments. The humor and satire that make Gipshut such a memorable work are perhaps the novel's most noteworthy representation of Weiterschreiben. As mentioned earlier, satirical and humorous writing - using the disguise of laughter and comedy to voice criticism or express dismay - was an established literary tradition in the GDR. It was one of the few ways in which writers were able express their dissent and point towards existing problems without having their works immediately censored. After the Wende, a wave of humorous and satirical literature spread through the East, partly because of the newly gained freedom of speech, but also because of the many frustrations and the disillusionment following the initial euphoria about the country's unification. ${ }^{117}$ What

\footnotetext{
${ }^{117}$ In the introduction to her study of post-Wende humorous and satirical writing in
} 
distinguishes Hensel's Gipshut from most of these works, however, is the quality of her writing.

Concerning the GDR-ness of Krauß's narrative strategies in Die Überfliegerin and Weggeküsst, I mentioned Christa Wolf as the most obvious link between Krauß and East Germany's literary tradition. The most obvious connection with Wolf is Krauß's poetic language, the slow and deliberate movement of her sentences, and the reflective quality of her narrating. Another commonality between Wolf and Krauß is the utopian tone of their texts. Though they may be lost and confused, Krauß's narrators never despair; they never give up their in people and their belief that one day they will arrive. Thus, unlike Wolf's, Krauß's is not a political utopia but one that is characterized by what Krauß calls "Gesamtliebe," which is the feeling of some deeper connectedness between people, and more generally, the ability to let oneself be carried away by life. Though not as obviously as Hensel's, Krauß's narratives, too, show some resemblance to Irmtraud Morgner's way of writing, in particular with respect to the dream-like and at times slightly surreal quality of her narrator's monologues and her occasional digression into the realm of fantasy. That being said, it must also be pointed out that Krauß very much developed her own way of writing and her own distinctive voice. To me this does not take away from the GDR-ness of her writing, though we must exclude her very recent fictional narrative. When we look at Krauß's own remarks about how she and her writing have been affected by the most recent historical developments in her country, there is no doubt that she has been writing GDR-literature.

East Germany, Humor, Satire, and Identity, Jill E. Twark mentions several possible reasons for why humorous and satirical writing is such a "widespread cultural phenomenon" in post-unification East Germany, among them the ones mentioned above $(1-8)$. 


\section{Weiterschreiben and Wendeliteratur}

The narratives by Hensel and Krauß discussed above are three representative examples of the kind of Weiterschreiben of GDR-literature to be found in East Germany's post-Wende literary scene. After the historical turn, many East German writers made it their mission to look back at a historical period, a society, and a way of life that no longer existed and/or give testimony about the ways in which unification has been affecting life in the East. They have done so in texts that display a wide range of feelings and attitudes, and some also carry on the writing styles of former GDR writers. There are, for example numerous light and entertaining fictions, such as Thomas Brussig's hilarious parable of the Fall of the Wall, Helden wie wir (1995), or Jana Hensel's slightly nostalgic childhood memoir Zonenkinder (2002), a depiction of life in the GDR. Two interesting literary phenomena are the monumental, historical fictions by Ingo Schulze and Uwe Tellkamp. Schulze's lengthy epistolary novel Neue Leben (2005) recounts the rather unglamorous life of an East German redneck, Enrico Türmer, against the background of past and present East German history. Similarly, Tellkamps' Der Turm. Geschichte aus einem versunkenen Land (2008) - a novel one critic so aptly labeled "ein grandioses Panorama vom Untergang der DDR"-focuses on the life of a group of middle class intellectuals (Bildungsbïrgertum) from Dresden during the final years of the GDR's existence. ${ }^{118}$ Finally, one must not forget the many works that stand out because of their singular writing styles and their literary qualities. The post-Wende fictions by Christa Wolf, Wolfgang Hilbig, and Rheinhard Jirgl need to be mentioned

\footnotetext{
${ }^{118}$ Elmar Krekeler, "Bei Uwe Tellkamp ticken die Uhren der DDR noch." WeltOnline http://www.welt.de/kultur/article2438531/Bei-Uwe-Tellkamp-ticken-die-Uhrender-DDR-noch.html. 12 February 2011. Page 1.
} 
here. Many of the works that deal with the GDR/new East topic may be of mediocre aesthetic quality and fall under the category of popular literature, but they are valuable contributions to our understanding of life in the other Germany because they provide important insight into the many ways in which Germany was, and to a certain extend still is, a divided country.

The label frequently applied to texts like the ones mentioned above is the term Wendeliteratur, although more and more critics and historians are questioning the term's usefulness. Originally, Wendeliteratur was an invention of the West German feuilleton in anticipation of a first merging of the two German literary scenes. As it turns out, however, predominantly East German writers wrote about the Wende-not surprisingly because it was people in the East who felt most dramatically the effects of the historical event. Regarding the term Wendeliteratur, the temporal parameters of the Wende are not easy to define, nor has it ever been decided what exactly the specific characteristics of this literature should be. Critic Astrid Köhler voices a valid concern shared by many who oppose the idea of a Wendeliteratur. She notes that the term Wendeliteratur is in fact only a continuation of the old problem of mixing matters of politics and aesthetics based on old political algorithms rather than on aesthetic phenomena. This problem is most clearly represented in the ongoing search for "the" Wenderoman, a search that is guided by cultural politics rather than aesthetic concerns. (Brückenschläge, 13). Another problem Köhler mentions is that the term is of little use to the serious literary critic. It invites a prioritizing of thematic issues to the detriment of a work's literary form and aesthetics.

At the same time, however, some distinction between the post-Wende literary production in East and West Germany is necessary. Simply absorbing GDR-literature 
into the canon of post- WWII German literature would represent a colonization of East Germany's literary heritage by the West. As Köhler, Kormann, and other critics have pointed out, there still is a noticeable difference between literary production in the two Germanys. This is certainly true with respect to choice of subject matter, and in many cases, as exemplified in my discussion of the three fictional narratives by Kerstin Hensel and Angela Krauß, these texts show a continuation of certain aesthetic characteristics. Köhler writes,

Und spätestens Mitte der neunziger Jahre haben die Autoren zurück zu ihren erprobten Schreibweisen gefunden, knüpfen daran an, entwickeln diese weiter und sorgen in jedem Fall dafür, dass ihre nun entstehenden Werke ihren eigenen Charakter behalten und in der gesamtdeutschen Literatur einen distinktiven Platz einnehmen. (12)

The field of GDR literature is a thing of the past; it came to an end with the dissolution of the state GDR. But GDR-literature as a regional literary phenomenon is still very much alive and plays an important role in contemporary Germany's literary scene. Perhaps it is best to think of GDR-literature as one of the "hybrid literary phenomena" (to use Wolfgang Emmerich's expression) in the literary scene of a multicultural Germany. ${ }^{119}$

${ }^{119}$ Wolfgang Emmerich used the expression "hybrid literary phenomena" in the abstract of a recent contribution to a symposium on GDR-literature at New College, Oxford (24-25 March 2011), organized by Prof. Karen Leeder. Emmerich's paper was entitled, "'GDR-literature': An Overview," and the symposium had the title 'Re-Reading East Germany': The Literature and Film of the GDR (1949-2009). At this point, only the abstract of Emmerich's paper is available. http://www.mod-langs.ox.ac.uk/gdrculture/Abstracts.pdf. 10 July 2011. 
At this point in time, a merging of the two post-WWII German literatures would be premature. It would also ignore the social and cultural differences between the two German states, which can still be felt today and which still inform the works of East German writers. Furthermore, such an undifferentiated view would drown out those aspects that define Germany's literary scene today-plurality, multiperspectivity, and diversity. Not only is German society becoming increasingly multicultural, but more importantly, as nations in the Europe of the twenty-first century are growing more and more together, the idea of a German Nationalliteratur is out of place, if not absurdly anachronistic. 


\section{Works Consulted}

\section{Post-Wende GDR Literary History}

\subsection{Literaturtstreit}

Anz, Thomas, ed. Es geht nicht um Christa Wolf. Der Literaturstreit im vereinten Deutschland. Rev. ed. Frankfurt a.M.: Fischer Taschenbuchverlag GmbH, 1995.

Bullivant, Keith. The Future of German Literature. Oxford: Berg Publishers, 1994.

Deiritz, Karl, and Hannes Krauss, eds. Der deutsch-deutsche Literaturstreit oder „Freunde, es spricht sich schlecht mit gebundener Zunge.“ Hamburg: Sammlung Luchterhand, 1991.

Heukenkamp Ursula. "Eine Geschichte oder viele Geschichten der deutschen Literatur seit 1945? Gründe und Gegengründe.” In Klaus-Dieter Hähnel. Zeitschrift für Germanistik. 1 (1995): 22-37.

Rosenberg, Rainer.'Was war DDR-Literatur? Die Diskussion um den Gegenstand in der Literaturwissenschaft der Bundesrepublik Deutschland.” In Hähnel: 9-21.

\subsection{East German Literature in General}

Arnold, Ludwig, ed. DDR-Literatur der neunziger Jahre. Text + Kritik. Sonderband (IX). München: Richard Boorberg Verlag, 2000.

Brockmann, Stephen. Literature and German Reunification. Cambridge: Cambridge University Press, 1999.

- - - German Literary Culture at the Zero Hour. Rochester, NY: Camden House, 2004. Brühns, Elke. Nach dem Mauerfall. Eine Literaturgeschichte der Entgrenzung. München: Wilhelm Fink Verlag, 2006. 
Cosentino, Christine. “Autobiographisch grundierte Rückblicke auf die DDR nach der Jahrtausendwende." Glossen, Heft 20.31 January 2005. $<$ http://www.dickinson.edu/departments/germn/glossen/heft20/cosentino.html $>$.

Delabar, Walter, Werner Jung and Ingrid Pergande, eds. Neue Generation-Neues Erzählen. Deutsche Prosaliteratur der achtziger Jahre. Opladen: Westdeutscher Verlag GmbH, 1993.

Erb, Andreas, ed. Bausstelle Gegenwartsliteratur. Die Neunziger Jahre. Opladen/Wiesbaden: Westdeutscher Verlag GmbH, 1998.

"Eine eigene Sprache finden." Walfried und Christel Hartinger sowie Peter Geist im Gespräch mit dem Lyrikern Thomas Böhme, Kurt Drawert, Kerstin Hensel, Dieter Kerschek, Bert Papenfuß-Gorek und Kathrin Schmidt. Weimarer Beiträge 4 (1990): 580-616.

Emmerich, Wolfgang. Kleine Literaturgeschichte der DDR. Erweiterte Neuausgabe. Berlin: Aufbau Taschenbuch Verlag, 2000.

- - - “'GDR-literature': An Overview." 'Re-Reading East Germany': The Literature and Film of the GDR (1949-2009). Symposium on GDR-literature at New College, Oxford (24-25 March 2011). Organizer, Karen Leeder. $<$ http://www.mod-langs.ox.ac.uk/gdrculture/Abstracts.pdf $>10$ July 2011.

Fischer, Gerhard and David Roberts, eds. Schreiben nach der Wende. Ein Jahrzehnt deutscher Literatur 1989 - 1999. Tübingen: Stauffenburg Verlag, 2007.

Förster, Nikolaus. Die Wiederkehr des Erzählens. Deutschsprachige Prosa der 80er und 90er Jahre. Darmstadt: Wissenschaftliche Buchgesellschaft, 1999. 
Freund, Wieland and Winifried Freund, eds. Der deutsche Roman der Gegenwart. München: Fink Verlag GmbH \& Co.KG, 2001.

Granzow, René. Gehen oder Bleiben? Literatur und Schriftsteller der DDR zwischen Ost und West. Berlin: Frank \& Timme GmbH, 2008.

Harder, Matthias, ed. bestandsaufnahmen. Deutschsprachige Literatur der neunziger Jahre aus interkultureller Sicht. Würzburg: Königshausen \& Neumann GmbH, 2001.

Helbig, Holger, ed. Weiterschreiben. Zur Literatur nach dem Ende der DDR. Berlin: Akademie Verlag GmbH, 2007.

Heukenkamp, Ursula. “Eine Geschichte oder viele Geschichten der deutschen Literatur seit 1945? Gründe und Gegengründe.” Zeitschrift für Germanistik. 1 (1995): 2237.

Kaes, Anton. "Literatur und nationale Identität: Kontroversen um Goethe 1945-49," in Albrecht Schöne. Ed. Kontroversen, alte und neue Akten des VII. Internationalen Germanisten-Kongresses Göttingen 1985. Vol.10. Göttingen: Niemeyer, 1986. 199-206.

Kammler, Clemens and Torsten Pflugmacher, eds. Deutschsprachige Gegenwartsliteratur seit 1989. Zwischenbilianzen - AnalysenVermittlungsperspektiven. Heidelberg: Synchron, 2004.

Kraft, Thomas, ed. aufgerissen. Zur Literatur der Neuziger Jahre. München: Piper Verlag GmbH, 2000. 
Krauss, Hannes. "Die Wiederkehr des Erzählens. Neue Beispiele der Wendeliteratur," in Clemens Kammler, Thorsten Pflugmacher, eds. Deutschsprachige Gegenwartsliteratur seit 1989. Zwischenbillanzen - Analysen Vermittlungsperspektiven. Heidelberg: Synchron 2004.

Krekeler, Elmar. "Bei Uwe Tellkamp ticken die Uhren der DDR noch.” Welt-Online. http://www.welt.de/kultur/article2438531/Bei-Uwe-Tellkamp-ticken-die-Uhrender-DDR-noch.html. 12 February 2011. Page 1. 97-10. Print.

Köhler, Astrid. Brückenschläge. DDR-Autoren vor und nach der Wiedervereinigung. Göttingen: Vandenhoeck \& Ruprecht: 2007.

Kormann, Julia. Literatur und Wende. Ostdeutsche Autorinnen und Autoren nach 1989. Wiesbaden: Deutscher Universitäts-Verlag, 1999.

Martens, Lorna. The Promised Land? Feminist Writing in the German Democratic Republic. Albany: State University of New York Press, 2001.

Mecklenburg, Norbert. "Verfremdete Nähe - Aspekte des Problemfeldes 'Literatur und Region' “ Diskussion Deutsch. 22 (1991): 337-347.

Reiman, Kerstin, E. Schreiben nach der Wende - Wende im Schreiben? Literarische Reflektionen nach 1989/90. Würzburg: Königshausen \& Neumann GmbH, 2008.

Twark, Jill E. Humor, Satire, and Identity. Eastern German Literature in the 1990s. Berlin: Walter de Gruyter, 2007.

Williams, Arthur, Stuart Parkes, Julian Preec, eds. German-Language Literature Today: International and Popular? Oxford/Bern: Peter Lang AG, 2000.

--- (Ed.). (1991). Writing clearly: bullets, white space and common sense. New York: Scootney Publishing. 


\section{Literary and Narrative Theory}

Bal, Mieke. Narratology. Introduction to the Theory of Narrative. Transl. Christine van Boheemen. Toronto: University of Toronto Press, 1985.

Cohn, Dorrit. Transparent Minds. Narrative Modes for Presenting Consciousness in Fiction. Princeton: Princeton University Press, 1978.

Gerard Genette. Narrative Discourse. An Essay in Method. Ithaca, N.Y.: Cornell Univeristy Press, 1980.

Grabes, Herbert. Einführung in der Literatur und Kunst der Moderne und Postmoderne. Tübingen: A. Francke Verlag, 2004.

Holman, Hugh and William Harmon. A Handbook to Literature. $6^{\text {th }}$ ed. New York: Macmillan Publishing Company, 1992.

Kreuzer, Helmut, hrsg. Pluralismus und Postmodernismus Frankfurt am Main: Peter Lang GmbH, 1989.

Stanzel, Karl. A Theory of Narrative. Cambridge: Cambridge University Press, 1984. Sprenger, Mirjam. Modernes Erzählen. Metafiktion im deutschsprachigen Roman der Gegenwart. Stuttgart: J.B. Metzler, 1999.

Wimmers, Inge Crosman. Poetics of Reading. Approaches to the Novel. Princeton, N.J.: Princeton University Press, 1988.

\section{Kerstin Hensel}

\subsection{Primary Literature}

Halimasch. München: Luchterhand Literaturverlag, 1989.

Im Schlauch. Frankfurt a. Main: Suhrkamp Taschenbuchverlag, 1993. 
Auditorium Panoptikum. Leipzig: Mitteldeutscher Verlag, 1991.

Angestaut. Aus meinem Sudelbuch. Mitteldeutscher Verlag: Halle, 1993.

Tanz am Kanal. Frankfurt a. Main: Suhrkamp Taschenbuchverlag, 1994.

Gipshut. Leipzig: Gustav Kiepenheuer Verlag, 1999.

Im Spinnhaus. München: Luchterhand Literaturverlag, 2003.

Falscher Hase. München: Luchterhand Literaturverlag, 2005.

Lärchenau. München: Luchterhand Literaturverlag, 2008.

\subsection{Individual Publications}

"Das Eine und nicht das andere. Zum Thema: Schreiben in der DDR.” Neue Deutsche Literatur 4 (1995): 19-23.

"Das große Fugato. Stephan Hermlin: 'Abendlicht'” Karl Deiritz und Hannes Krauss. Verrat an der Kunst? Rückblicke auf die DDR-Literatur. Berlin: Aufbau Taschenbuch Verlag, 1993: 109-113.

“Über dem Jammertal.” Zeitschrift für Publizistik und Kunst 2 (1993): 33-35. Print.

\subsection{Interviews}

Bernig, Jörg. Conversation “Über das Schreiben,” with Kerstin Hensel. Literaturlandschaft im Wandel. Gespräche zur literarischen Kultur in Sachsen und Ostdeutschland 1990 bis 2005. Eds. Jörg Bernig and Walter Schmitz. Dresden: w.e.b. Universitätsverlag, 2006.

Dahlke, Birgit. “Der langsame Blick, der gute Text: Gespräch mit Kerstin Hensel.” Neue Deutsche Literatur 4 (2000): 41-53. 
Deiritz, Karl and Rolf Stefaniak “'Ich teste meine Grenzen aus.' Gespräch mit Kerstin Hensel.” Deutsche Volkszeitung 3. Nov. 1989: 9.

Erb, Elke. Diana! Zeichnungen von Karla Woisnitza mit einem Gespräch von Elke Erb und Kerstin Hensel. Berlin: Kontextverlag, 1993.

Hammer, Klaus. “Gespräch mit Kerstin Hensel.” Weimarer Beiträge 1 (1991): 93-110.

Néy, Karin und Kerstin Hensel. „Letztlich will ich nichts, als Aufklärer sein.” Ein

Gespräch. In: Temperamente. Blätter für junge Literatur. 3 (1989): 3-12.

\subsection{Secondary Literature}

Baumann, Antje. "Das Komische begreifen, ohne es fassen zu können: Gegenwelten in Gipshut.” In Linklater and Dahlke, 120-134.

Dahlke, Brigit. “Traumtanz mit Klumpfüßen. Kerstin Hensel blickt zurück: Leben im Gipsverband.” Neue Deutsche Literatur 1 (2000): 180-182.

Döbler, Katharina. "Ein Deutscher namens Hans. Kerstin Hensels Roman Gipshut.” Neue Züricher Zeitung. Internationale Ausgabe 23 Nov. 1999: 35.

Franke, Konrad. "Weh dem, der am Gipshut bohrt. Kerstin Hensels DDR-Märchen.” Süddeutsche Zeitung 8/9 Jan. 2000: iv.

Hahn, Anne. "Den Palast wegpusten. Kerstin Hensel entdeckt einen Vulkan mitten in Berlin.” Literaturkritik 3 (2000). 30 June 2008. $<$ http://www.literaturkritik.de/public/rezensionen.php?rez_id=900\&ausgabe=200 $003>$.

Linklater, Beth and Birgit Dahlke, eds. Kerstin Hensel. Cardiff: University of Wales Press, 2002. 
Mabee, Barbara. "'Wem dient ich? Dient ich nicht / Dem eignen Schwein': Ost-West Kontraste, Erinnerungsspuren und Identitätssuche in Kerstin Hensels Lyrik und Erzählungen nach der Wende.” Glossen Sonderausgabe/Special Issue 15 (2002): 2 July 2005. <http://www.dickinson.edu/departments/germn/glossen/heft15/mabee.html>. Maidt-Zinke, Kristina. "Mit Dachschaden. Kerstin Hensel lüpft den Gipshut.” Frankfurter Allgemeine Zeitung 12 Febr. 2000: v.

Marven, Lyn. Body and Narrative in Contemporary Literatures in German. Herta Müller, Libuše Moníková, and Kerstin Hensel. Oxford: Clarendon Press, 2005.

- - - “'Nur Manchmal mussten sie laut und unverhofft lachen': Herstin Hensel's Use of Märchen.” Heike Bartel and Elizabeth Boad, eds. Pushing at Boundaries. Approaches to Contemporary German Women Writers from Karen Duve to Jenny Erpenbeck. Amsterdam-New York, N.Y.: Rodopi, 2006.

Meyer-Gosau, Frauke. “Aus den Wahnwelten der Normalität. Über Brigitte Kronauer, Elfriede Jelinek und Kerstin Hensel.”Vom Gegenwärtigen Zustand der deutschen Literatur. Ed. Ludwig Arnold. München: text + kritik, 1992: 26-37.

Skare, Roswitha. "Identitätskonstrukte in Texten junger ostdeutscher Autoren nach 1989/90. Zu Kerstin Hensel: Tanz am Kanal (1994).” Nordlit 16 (2004): 95-112. <http://www.ub.uit.no/munin/handle/10037/462>

Schmidt, Kathrin. "Frühkindliche Infektion mit Gedrucktem: Ein konservatives Stück Text. Kerstin Hensels neuer Roman Gipshut.” Freitag 8 Oct. 1999: ix.

Steingröver Reinhild, “'Not Fate-Just History’: Stories and Histories in Tanz am Kanal and Gipshut.” In Linklater and Dahlke, 91-106. 


\section{Angela Krauß}

\subsection{Primary Literature}

Das Vergnügen. Frankfurt a. Main: Suhrkamp Verlag, 1988. (First publication in the GDR, Berlin und Weimar: Aufbau-Verlag, 1984.)

Dienst-Jahre und andere Prosa. Berlin und Weimar: Aufbau-Verlag, 1991.

Glashaus. Berlin und Weimar: Aufbau-Verlag, 1988.

Der Dienst. Frankfurt a. Main: Suhrkamp Verlag, 1990. (First publication in the GDR, Berlin und Weimar: Aufbau-Verlag, 1988.)

Die Überfliegerin. Frankfurt a. Main: Suhrkamp Verlag, 1995.

Sommer auf dem Eis. Frankfurt a. Main: Suhrkamp Verlag, 1998.

Milliarden neuer Sterne. Frankfurt a. Main: Suhrkamp Verlag, 1999.

Weggeküsst. Frankfurt a. Main: Suhrkamp Verlag, 2002.

Die Gesamtliebe und die Einzelliebe. Frankfurter Poetikvorlesungen. Frankfurt a. Main: Suhrkamp Verlag, 2004.

Wie weiter. Frankfurt a. Main: Suhrkamp Verlag, 2006.

Ich muß mein Herz üben. Gedichte. Frankfurt am Main: Insel Verlag, 2009.

Im schönsten Fall. Berlin: Suhrkamp Verlag, 2011.

4.2. Individual Publications

“Erneuter Versuch darüber zu redern.” In Positionen; Wortmeldungen zur DDR-

Literatur. Bd. 2. Halle: Mitteldeutscher Verlag, 1986: 82-86. 
"Die Lage im Osten.” Contribution to the Symposion der Deutschen Literaturkonferenz, "Wachsende Verstörung - florierender Betrieb? Zur Situation der deutschen Literatur im dritten Einigungsjahr.” Leipzig, 6 April 1993. ndl 41 Heft 8 (1993): $161-216$.

“Mit der Zeit erzählen.” In Mit der Zeit erzählen? Marcel Beyer, Heiner Egge, Gundi Feyrer, Yoko Tawada. Das zweite Buch. Ed. Hugo Dittberner et al. Göttingen: Wallstein, 1994. 121-123.

“Murmeln in meiner Tasche.” FIGARO-Kolumnen: Die Öffnung zur Welt. MDR-Figaro. 1 Oct 2009. Web 20 Mar 2010. <http://www.mdr.de/mdr-figaro/journal/6736937-hintergrund-6635231.html>

"Reihe generation '89." Semper! Hrsg. Semperoper Dresden. Juni/Juli/August/ September 2009: 70-73.

"Der Wortkünstler im Zwischenraum.” Die Ethik der Literatur: Deutsche Autoren der Gegenwart. Eds. Paul Michael Lützeler, Jennifer M. Kapczynski. Göttingen: Wallstein, 2011. 118-124.

\subsection{Interviews and Conversations}

Klassen, Julie. “'Whenever a Living Human Being Approaches Me, I Forget Everything I've Ever Learned': Interview with Angela Krauß," Women in German Yearbook: Feminist Studies in German Literature and Culture 25 (2009): 223-232. Project Muse. Web. 14 May 2010.

Jarmatz, Ingrid. "Biste für immer hier.” Interview mit Angela Krauß. Sonntag 15 July 1984: 4 . 
Magenau, Jörg. "Die Realität zum Schweben bringen. Gespräch mit der Leipziger Autorin Angela Krauß über die Wende und die Wendeliteratur, über Bahnhöfe, Flugzeuge und Reisen, das Sichtbare, das Unveränderliche, das Politische und das Poetische," Freitag 13 Oct. 1995: III, IV.

Rosenlöcher, Thomas. "Stockende Tinte. Sechs Jahre durchsetzt von Raserei, Versagensgefühlen, Utopie: ein Gespräch mit Angela Krauß und Thomas Rosenlöcher," Grauzone-Zeitschrift über neue Literatur 9./10. Januar 1997: 2427.

\subsection{Secondary Literature}

Eke, Norbert Otto. "Das Schweben und die Form. Angela Krauß’s Erzählkunst," ndl 50. Heft 541 (2002): 129-137.

Hamm, Peter. "Der Ernstfall der Sehnucht. Laudatio zur Verleihung des Hermann LanzPreises am 22 Juni 2007.” Web. 7 Aug. 2011. <http://www.suhrkamp.de/download/Sonstiges/PeterHamm_Laudatio_2007.pdf>

Krass, Stephan. “Angela Krauss: Diskrete Botschaften oder das Erzählen, das aus der Zahl kommt." Die Ethik der Literatur: Deutsche Autoren der Gegenwart. Eds. Paul Michael Lützeler, Jennifer M. Kapczynski. Göttingen: Wallstein, 2011. 109117)

Lützeler, Paul Michael. "Vereinigung und Entropie. Der Schock einer Zeitenwende: Die Überliegerin von Angela Krauß.” Neue Rundschau 109. 3 (1998): 142-154. 
- - - "Von Angst und Euphorie: Angela Krauß’s Erzählung 'Die Überfliegerin.” Die Ethik der Literatur: Deutsche Autoren der Gegenwart. Eds. Paul Michael Lützeler, Jennifer M. Kapczynski. Göttingen: Wallstein, 2011. 125-135.

Mabee, Barbara. “'Das Weltbild korrigieren. Nachdenkliche Fortsetzung der Fahrt': Angela Krauß' poetisierte Amerikareisen als Umdenkprozesse und Aufbrüche zu neuen Lebensmustern.” Glossen Sonderausgabe/Special Issue 19 (2004): n. pag. Web. 31 Jan. 2005. $<$ http://www. Dickinson.edu/departments/germn/glossen/heft19/mabee.html> Mittmann, Elizabeth. "On the Road to Nowhere: Utopian Geography in Post-Unification Literature." Seminar. A Journal of Gernamic Studies. Ed. Rodney Symington. 37.4 (2001): 336-354.

Nentwich, Andreas. "Im Zoo der wahren Empfindung. Angela Krauß sucht die blaue Blume und sorgt für Überraschungen.” Die Zeit. Literatur Sonderbeilage November 2002: 12-13.

Opitz, Michael. “Nichts ist an seinem Platz. Ortlos. In Angela Krauß’ neuer Erzählung 'Weggeküsst' hat sich über Nacht die Welt verwandelt.' Freitag 8 Nov. 2002: 46.

Vormweg, Heinrich. "Das Schwere und das Leichte. Angela Krauß aus Leipzig erzählt vom Umbruch in ihrem Leben.” Beiträge der Süddeutschen Zeitung 11 Oct. 1995: L6.

Wiemers, Carola. 'Zwischen gestern und morgen. Angela Krauß’s Roman 'Wie weiter' ist wieder ein sprachliches Tanzvergnügen," dradio.de. Web. 20 March 2010. $<$ http://www.dradio.de/dkultur/sendungen/kritik/530916> 
Winkels, Hubert. “Sofasägen am Kopfbahnhof. Angela Krauß’ Erzählung ‘Die Überfliegerin."” Die Zeit 13 Oct. 1995:10.

5. Other Authors

Maron, Monika. Die Überläuferin. Frankfurt a. Main: Fischer Verlag, 1986.

Morgner, Irmtaud. Leben und Abenteuer der Trobadora Beatriz nach Zeugnissen ihrer Spielfrau Laura. Hamburg: Luchterhand Literatur Verlag, 1976. (First publication in the GDR, Berlin und Weimar: Aufbau-Verlag, 1974.)

Wolf, Christa. Der geteilte Himmel. München: Deutscher Taschenbuch Verlag, 1973. (First publication in the GDR, Halle/Saale: Mitteldeutscher Verlag, 1963.)

- - - Nachdenken über Christa T.. Frankfurt: Luchterhand Literaturverlag, 1971. (First publication in the GDR, Halle/Saale: Mitteldeutscher Verlag, 1968.)

- - - Kindheitsmuster. Darmstadt: Sammlung Luchterhand, 1979. (First publication in the GDR, Berlin und Weimar: Aufbau-Verlag, 1976.)

- - Kassandra. Darmstadt: Herman Luchterhand Verlag, 1986.

- - - Was bleibt. München: Luchterhand Literaturverlag GmbH, 1993.

- - - Dimensionen des Autors. Essays und Aufsätze. Reden und Gespräche 1959-1985. Auswahl: Angela Drescher. Darmstadt: Luchterhand Verlag, 1987.

Plenzdorf, Ulrich. Die neuen Leiden des jungen W. Frankfurt a. Main: Suhrkamp Taschenbuch Verlag, 1976. (First publication in the GDR, Rostock: Hinstorff Verlag, 1973.) 